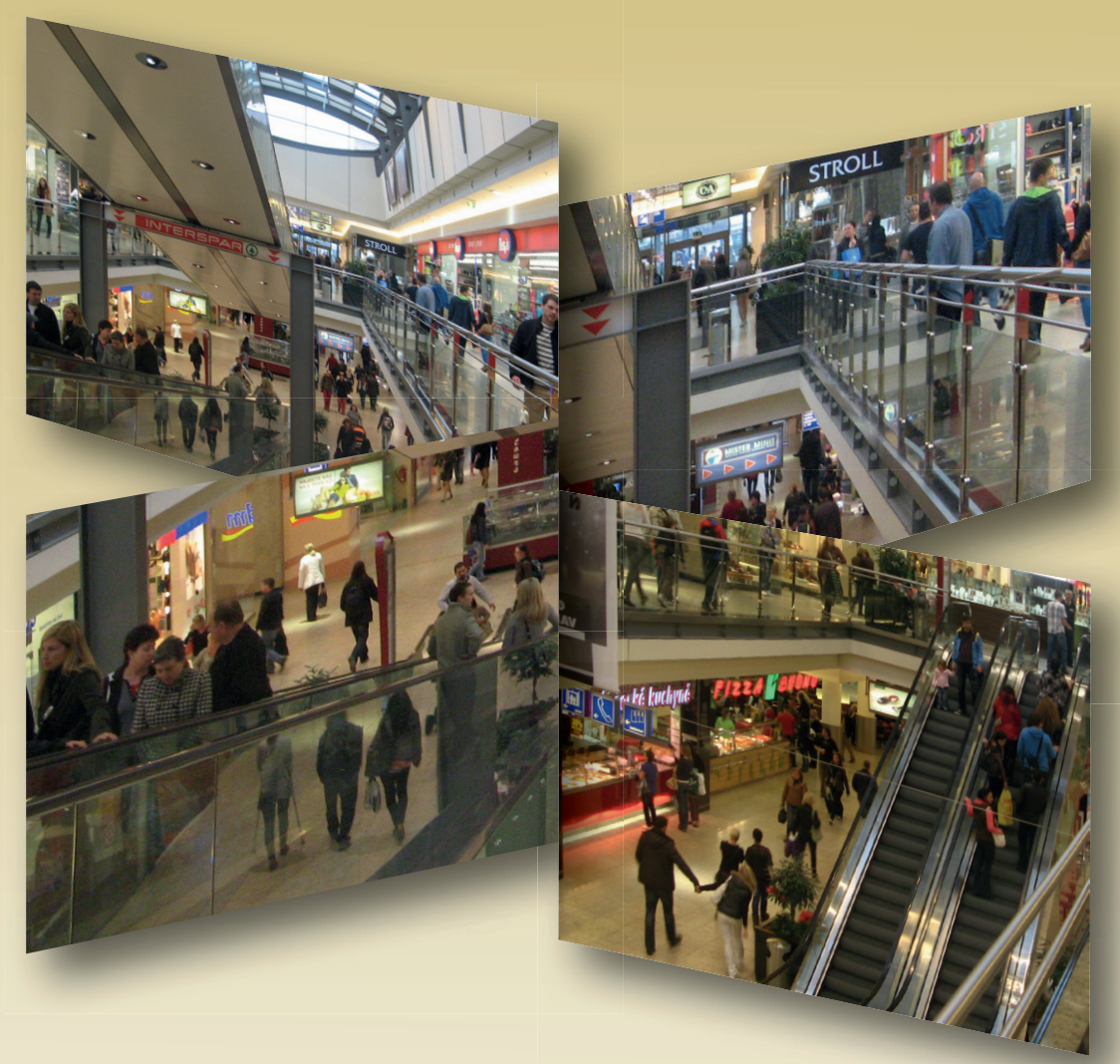

\title{
ČASOPROSTOROVÉ MODELY NÁKUPNÍHO CHOVÁNÍ ČESKÉ POPULACE
}

Josef KUNC . a kolektiv

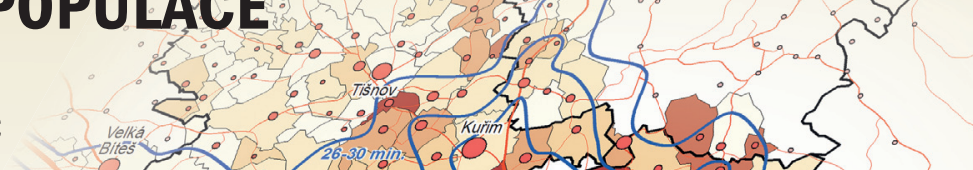




\title{
ČASOPROSTOROVÉ MODELY NÁKUPNÍHO CHOVÁNÍ ČESKÉ POPULACE
}

\author{
Josef KUNC a kolektiv
}

Všechna práva vyhrazena. Žádná část této elektronické knihy nesmí být reprodukována nebo šířena $\mathrm{v}$ papírové, elektronické či jiné podobě bez předchozího písemného souhlasu vykonavatele majetkových práv $\mathrm{k}$ dílu, kterého je možno kontaktovat na adrese - Nakladatelství Masarykovy univerzity, Žerotínovo náměstí 9, 60177 Brno.

\section{munı \\ PRESS}




\section{Knihu recenzovali:}

prof. RNDr. Viliam Lauko, CSc.

Mgr. Ondřej Mulíček, Ph.D. 


\section{ČASOPROSTOROVÉ MODELY NÁKUPNÍHO CHOVÁNÍ ČESKÉ POPULACE}

Josef KUNC a kolektiv 


\section{Autorský kolektiv:}

RNDr. Josef Kunc, Ph.D. ${ }^{1}$ : editor, kapitoly 1, 2, 3, 4, 5, 6, 7, 8, 9, 12

RNDr. Jaroslav Maryáš, CSc. ${ }^{1}$ : kapitoly 2, 7, 8

Mgr. Petr Tonev ${ }^{1}$ : kapitoly 4, 5, 6, 7, 8, 9

RNDr. Bohumil Frantál ${ }^{1,3}$ : kapitoly 6, 7, 9

doc. RNDr. Tadeusz Siwek, CSc. ${ }^{1,4}$ : kapitoly 4

RNDr. Marian Halás, Ph.D. ${ }^{2}$ : kapitoly 2, 10

Mgr. Pavel Klapka, Ph.D.' ${ }^{2}$ kapitoly 2, 11

doc. RNDr. Zdeněk Szczyrba, Ph.D.'2: kapitoly 1, 2, 4, 7, 9

Mgr. Veronika Zuskáčová2: kapitola 10

\section{Institucionální zastoupení:}

${ }^{1}$ Masarykova univerzita, Ekonomicko-správní fakulta, Brno

${ }^{2}$ Univerzita Palackého, Př́rodovědecká fakulta, Olomouc

3 Ústav geoniky AV ČR, v. v. i., Brno

${ }^{4}$ Ostravská univerzita, Př́rodovědecká fakulta, Ostrava

Tato kniha vznikla v rámci řešení projektu GA AV ČR č. IAA301670901

„Časoprostorová organizace denních urbánních systémů: analýza a hodnocení vybraných procesů“.

(C) 2013 Josef Kunc, Jaroslav Maryáš, Petr Tonev, Bohumil Frantál, Tadeusz Siwek, Marian Halás, Pavel Klapka, Zdeněk Szczyrba, Veronika Zuskáčová

(C) 2013 Masarykova univerzita

ISBN 978-80-210-6465-2

ISBN 978-80-210-6020-3 (brož. vaz.)

DOI 10.5817/CZ.MUNI.M210-6020-2013 


\section{OBSAH}

Stručná charakteristika autorského kolektivu . . . . . . . . . . . . . . 7

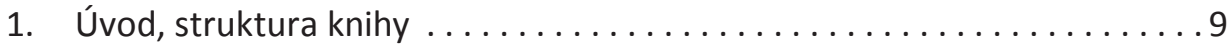

2. Nákupní chování jako sociálně-prostorový fenomén:

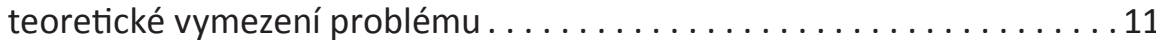

3. Základní metodický přístup k provedeným šetřením ............29

4. Vývoj maloobchodu v České republice.................... 31

5. Nákupní centra a jejich specifika. . . . . . . . . . . . . . . . 57

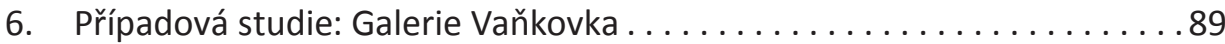

7. Brněnská aglomerace: denní i nedenní dojížd'ka za maloobchodem, nákupní spád a nákupní chování obyvatel v zázemí Brna . . . . . . . . . . . . 101

8. Brněnská aglomerace: spádovost za službami a její vývoj na příkladě obslužných procesů v zázemí Brna . . . . . . . . . . . . . 117

9. Brněnská aglomerace: denní i nedenní dojížd'ka za maloobchodem, nákupní spád a nákupní chování ve vnitřním Brně . . . . . . . . . . . 125

10. Olomoucká aglomerace: spádovost za službami v denním urbánním systému Olomouce. . . . . . . . . . . . . . . . . . . . . 141

11. Modelování intra-urbánních nákupních pohybů obyvatelstva: př́klad města Olomouc . . . . . . . . . . . . . . . . . . . . . . . . . . 159

Závěrečné shrnutí. . . . . . . . . . . . . . . . . . . . . . . . . . . . . . 173

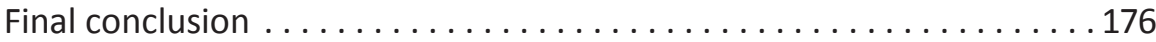

Použitá literatura . . . . . . . . . . . . . . . . . . . . . . . . . . . . . . . . . . . 179

Věcný rejstř́ík . . . . . . . . . . . . . . . . . . . . . . . . . . . 193 



\section{STRUČNÁ CHARAKTERISTIKA AUTORSKÉHO KOLEKTIVU}

RNDr. Josef Kunc, Ph.D. (narozen 1973), editor knihy, působí na Katedře regionálního rozvoje a správy Ekonomicko-správní fakulty Masarykovy univerzity v Brně. Předmětem jeho zájmu je geografie maloobchodu a nákupního chování, geografie průmyslu s důrazem na problematiku brownfields a cestovní ruch.

Doc. RNDr. Zdeněk Szczyrba, Ph.D. (narozen 1966) je vedoucím Katedry geografie Prrírodovědecké fakulty Univerzity Palackého v Olomouci. Předmětem jeho zájmu je geografie obchodu a služeb, geografie bydlení, průmyslu a regionální rozvoj.

Mgr. Pavel Klapka, Ph.D. (narozen 1977) pracuje na Katedře geografie Př́rodovědecké fakulty Univerzity Palackého v Olomouci. Zabývá se geografickou organizací prostoru, především regionální taxonomií, modelováním prostorových interakcí a geografií času.

Mgr. Petr Tonev (narozen 1974) pracuje na Katedře regionálního rozvoje a správy Ekonomicko-správní fakulty Masarykovy univerzity v Brně. Předmětem jeho zájmu je dojížd'ka v rámci geografie obyvatelstva, geografie průmyslu a regionální rozvoj.

RNDr. Bohumil Frantál (narozen 1975) je vědeckovýzkumným pracovníkem Ústavu geoniky AV ČR, v. v. i., oddělení environmentální geografie v Brně. Zabývá se problematikou sociálních konfliktů v kontextu využivání krajiny, percepcí environmentálních rizik, otázkami regionálních a lokálních identit, kvalitou života a prostorovými modely lidského chování.

Doc. RNDr. Marián Halás, Ph.D. (narozen 1973) pracuje na Katedře geografie Př́rodovědecké fakulty Univerzity Palackého v Olomouci. Předmětem jeho zájmu je geografická organizace prostoru, aplikace kvantitativních metod a problematika příhraničních, resp. periferních regionů.

RNDr. Jaroslav Maryáš, CSc. (narozen 1951) působí na Katedře regionálního rozvoje a správy Ekonomicko-správní fakulty Masarykovy univerzity v Brně. Zabývá se geografií služeb, zejména problematikou prostorových interakcí vázaných na obyvatelstvo. 
Doc. RNDr. Tadeusz Siwek, CSc. (narozen 1953) je zaměstnán na Katedře sociální geografie a regionálního rozvoje Př́rodovědecké fakulty Ostravské univerzity. Zabývá se kulturní geografií a vybranými teoretickými otázkami v geografickém výzkumu, zejména percepcí geografického prostoru nebo difuzními procesy.

Mgr. Veronika Zuskáčová (narozena 1986) absolvovala obor regionální geografie na Prírodovědecké fakultě Univerzity Palackého v Olomouci. V současnosti je doktorandkou na Geografickém ústavu Přírodovědecké fakulty Masarykovy univerzity v Brně. Předmětem jejího zájmu je geografie dopravy a služeb. 


\section{1. Úvod, struktura knihy}

Globalizace jako současný celospolečenský fenomén zasahuje všechny oblasti našeho života. Neprojevuje se jenom v ekonomické sféře, ale výrazně ovlivňuje také společnost a každodenní život jedince, jeho chování a kulturní návyky (Bauman, 1998, 2007; Giddens, 2002). Předchozí sociologický diskurs z 90. let 20. století o západní kulturní dominanci a přejímání západních spotřebních vzorců ve světě (tzv. mcdonaldizace, viz také Ritzer, 1999) doznal určité úpravy, jak se o ní zmiňuje Connell (2007) ve své studii o polarizační teorii globalizace. Společnost si uchovává svou kulturní diverzitu, přejímané kulturní a spotřební vzory vytvářejí nové společenské mozaiky a hybridity. Globalizace představuje evoluční trend ve vývoji společnosti, tedy i globalizace spotřebních vzorců je dalším z řady vývojových stupňů změn ve společenské spotřebě (Križan, 2009).

Vývoj české společnosti po roce 1989 byl vržen do kontextu celosvětové globalizace. Česká společnost, která do té doby vykazovala známky kulturní i ekonomické izolovanosti, se začala vyrovnávat s jejími důsledky. Velmi rychle se přizpůsobila inovacím v odvětví maloobchodu a zásadním způsobem změnila svůj dosavadní model nakupování (viz dále). Jinde měly globalizační efekty pozvolnější průběh, masivní konfrontace společnosti s „výdobytky globalizace“ proběhla v jiných segmentech ekonomiky později. Jak ukazuje dosavadní vývoj, modernizace ekonomiky předčila modernizaci společnosti, kterou rozumíme optimalizaci regulačních funkcí státu a občanského sektoru (Frič, Potůček, 2004). ${ }^{1}$

Globalizační trendy v odvětví maloobchodu v České republice patří k nejviditelnějším rysům socioekonomické transformace po roce 1989. Snad proto, že zanedbanost prostoru pro uspokojování nákupních potřeb byla v českých reáliích v období centrálně plánované ekonomiky velmi vysoká ve srovnání s tržními ekonomikami v západní Evropě (Krásný, 1990) a nutnost změnit tyto poměry v nových demokratizačních časech byla velmi silná. Hovoříme-li o českých reáliích, pak zdejší transformace v odvětví maloobchodu patří k nejrazantnější ve skupině postsocialistických zemí ve střední Evropě. Dokladem budiž výzkumy trhu ze strany společnosti Incoma GfK (např. Retail Census 99), která se dlouhodobě zabývá monitoringem maloobchodu.

Maloobchod nepředstavuje tak sofistikované odvětví jako výroba nebo výzkum (jak z pohledu lidských zdrojů, tak infrastruktury), což znamená, že dochází k relativně rychlému zprovozňování nových prodejen napřič celým sídelním systémem (Viturka et al., 1998). Navíc zde nejsou dostatečně uplatňovány regulační

V širším vymezení se společenskou modernizací rozumí veřejně diskutovaný a konfliktní proces inovace vývojových potenciálů, institucí, právních norem, hodnot a kulturních vzorů a dalších regulátorů společenského života (Frič, Potůček, 2004: 425). 
mechanismy, byt' u nás existuje zákonná úprava o podmínkách územního plánování (zákon č. 183/2006 Sb., o územním plánování a stavebním rrádu). Pro nadnárodní maloobchodní řetězce se tak otevírá prakticky bezkonfliktní rozvoj v jejich expanzi na český trh (Szczyrba, 2005; Koželouh, 2010; Spilková, Šefrna, 2010). V soudobé fázi spotřeby je charakteristickým rysem účelová spotřeba komodit, která vyjadřuje odlišnosti od ostatních spotřebitelů a sounáležitosti k určité sociální a kulturní společnosti (Shields, 1992 cit. in Spilková, 2012).

Cílem předložené publikace je seznámit odbornou i širší veřejnost s hlavními výsledky projektu „Časoprostorová organizace denních urbánních systémů: analýza a hodnocení vybraných procesů“. Denní pohyb obyvatel není ovšem v našem případě vázán na pohyb za prací, ale je modifikován dojížd'kou za službami a specificky za maloobchodem, resp. novými formami nákupního chování. Denní urbánní systém je tedy pojat volněji, protože je utvářen a modelován pomocí dat, jež nejsou běžnou statistikou evidována. Datovou základnou se stala rozsáhlá šetření v modelových aglomeracích Brna a Olomouce.

První část textu je věnována teoretickému ukotvení řešené problematiky, přičemž je kladen důraz na nákupní chování jako sociálně-prostorový fenomén, a to $v$ celé šíři obsahu tohoto pojmu. Dále stručně prezentujeme základní metodické přistupy $\mathrm{k}$ výzkumům a šetřením, přičemž konkrétní metodiku $\mathrm{k}$ dílčím výzkumům uvádíme, pro lepší přehlednost textu, vždy před danou kapitolou. Následuje širší pasáž stručně charakterizující vývoj českého maloobchodu s důrazem na jeho transformaci po roce 1989, vznik nové prostorové struktury, sítování a postupnou difúzi nových velkoformátových konceptů, plánování v maloobchodě a aktuální trendy v urbánním prostředí. Na ni navazuje část věnující se patrně aktuálně největšímu maloobchodnímu fenomému - nákupním centrům, jejich vzniku, vstupu a vývoji na českém trhu, lokalizačním aspektům, ale i počínajícím problémům. Ucelený blok uzavírá případová studie nákupního chování návštěvníků známého nákupního centra Galerie Vaňkovka v Brně.

Další část textu již představuje výsledky výzkumů v prvním z modelových měst - z Brna, přičemž se jedná o denní i nedenní dojižd'ku za maloobchodem, nákupní spád a nové trendy v nákupním chování obyvatel brněnské aglomerace. Výzkumy byly prováděny jak v obcích v zázemí Brna, tak uvnitř městské struktury. $\checkmark$ případě druhého modelového města - Olomouce - byly výzkumy dojížd'ky a nákupního spádu za obchodem, resp. službami, zaměřeny více na modelování prostorových interakcí, a to jak v rámci vymezeného denního urbánního systému města (proběhlo také vlastní šetření v obcích v zázemí), tak v rámci jeho intraurbánních struktur.

Přestože jsme si vědomi, že výsledky výzkumů a jejich interpretace nelze považovat za komplexně reprezentativní např. na úrovni celého státu, je možno některé závěry zobecnit a využít pro srovnání s podobně koncipovanými výzkumy v jiných metropolitních oblastech. 


\section{Nákupní chování jako sociálně-prostorový fenomén: teoretické vymezení problému}

\subsection{Proměny nákupních zvyklostí české společnosti po roce 1989}

Nákupní zvyklosti české populace byly před rokem 1990 dlouhá desetiletí ovlivňovány a regulovány směrnicemi centrálně rízené socialistické ekonomiky v oblasti vnitřního obchodu, které mimo jiné direktivně určovaly místa spotřeby i to, co se $v$ nich bude prodávat. Lokalizace prodejen nerespektovala rozmístění koupěschopné poptávky, díky čemuž byla na jedné straně obchodně přetěžována centra většiny měst, na straně druhé chyběla adekvátní výstavba nákupních středisek v nově budovaných sídlištních souborech (Szczyrba, 2005). Poloha ve městě byla ekonomicky nerelevantní, takže centra měst nebyla dlouho preferována pro výstavbu komplexnějších nákupních středisek (Musil, 2001). Nic na tom nezměnila ani zvýšená intenzita výstavby obchodních domů v 70. a 80. letech minulého století, která měla za cíl eliminovat rostoucí nespokojenost obyvatel $s$ rozsahem i kvalitou obchodní nabídky. ${ }^{2}$ Často $s$ tímto všeobecně neutěšeným stavem kontrastovala výstavba prodejních kapacit na venkově (ve srovnání s městským prostorem) při celkově podprůměrných investicích do rozvoje maloobchodu ve srovnání se státy v západní Evropě. Akceptování těchto sociálních principů dosáhlo v tehdejším Československu nejvyšší úrovně ve skupině středoevropských socialistických zemí (Krásný, 1990).

$\checkmark$ první polovině 90 . let 20 . století, kdy byla uskutečněna rozsáhlá vlna privatizace a liberalizace ekonomického prostředí, se u nás začínaly objevovat první velkoplošné prodejny zahraničních maloobchodních řetězců. Tato první iniciační fáze transformace spotřebitelského chování byla založena na rozvoji nových supermarketových sítí, které byly budovány jak na zelené louce v místech, kde chyběla odpovídající maloobchodní nabídka, tak remodelovány na půdorysech bývalých velkoprodejen potravin podle jejich provozních požadavků. Vstupní etapa pronikání zahraničních maloobchodních řetězců na trhy je spíše opatrná, teprve

2 Dodnes tyto relikty socialistického maloobchodu budí rozpaky ve společnosti. Jednak co se týče architektury, která je považována za nevhodnou a nekvalitní, a jednak urbanistickým řešením (např. obchodní dům PRIOR lokalizovaný na centrálním náměstí v Jihlavě). V posledních letech dochází k postupné revitalizaci obchodních domů z dob socialismu (nejnověji obchodní dům PRIOR v Olomouci, který se změní v moderní nákupní centrum). Ve spektru nákupních příležitostí se jim tak otevírají nové možnosti, předchozí stav (kvalita prodeje) zákazníky spíše odrazoval. 
v následujícím období probíhá jejich sílící expanze a s tím související masivní transformace nákupních zvyků (Dicken, 2003). V tomto kontextu byla druhá fáze (druhá polovina 90 . let 20 . století) transformace maloobchodu ve znamení ještě intenzivnějšího rozvoje dalších formátů velkoplošných prodejen, nejdřive v linii diskontních prodejen, o něco později přišla vlna „hypermarketového boomu“" To se projevilo rychlým príklonem nákupního chování k těmto moderním velkoplošným prodejnám. Určitým dokladem velmi rychlé akceptace velkoplošných prodejen zahraničních maloobchodních řetězců může být mj. sociálně psychologický experiment Český sen (Czech Dream) z roku 2002, který pojednává o fiktivním hypermarketu a vlivu reklamy na spotřebitelské chování (Vysekalová, 2003). Jiným sofistikovaným zdrojem dat o změnách v preferencích spotřebitelů pro určitý typ prodejny, popř́padě konkrétní maloobchodní řetězec, jsou výzkumy společností Incoma Research a GfK (např. Shopping Monitor).

Jak ukázaly výsledky komparativních studií, ze zemí Visegradské skupiny (V4) nejvíce své spotřebitelské návyky změnila česká společnost, přičemž zaznamenala největší příklon k hypermarketům (Szczyrba, 2005: 76; Spilková, 2012a). ${ }^{4}$ A to i přesto, že privátní maloobchodní sektor se nejrychleji etabloval nikoliv v České republice, ale v Mad'arsku (Douglas, 1995). Charakteristickým rysem třetí fáze vývoje, začínající na přelomu 20. a 21. století, je dynamický rozvoj nákupních center jako nového sociálního prostoru (Goss, 1993), zprvu masivně se rozvíjející na okrajích velkých českých měst, kde byl dostatek plochy pro jejich výstavbu. Před několika lety se ovšem vývoj obrátil směrem $k$ daleko intenzivnějšímu využívání ploch i objektů v centrech měst, kde předtím desítky let stávaly továrny nebo jiné objekty typu brownfields a které změnily svou funkci na moderní nákupní centra (např. Galerie Vaňkovka, Nová Karolina) (Steinführer, 2006; Kuda, Smolová, 2007; Kunc et al., 2011, 2012a). Tento trend rozhodně není u konce, městská jádra a jejich blízké okolí čeká další vlna výstavby nejen maloobchodních struktur. Je jen otázkou času, kdy se plně projeví.

A jaké jsou aktuální změny v nákupním chování české populace? Podle vyjádření odborníků z renomované společnosti Incoma GfK ${ }^{5}$ Ize současný vývoj shrnout do dvou hlavních trendů. První se v širším slova smyslu projevil pragmatismem či racionalitou nakupování a spotřeby. Ještě před několika lety dominoval

3 V roce 1997 byly otevřeny desítky diskontních prodejen řetězců Penny a Plus Discount, tento rok je také označován jako „rok diskontů“ (Szczyrba, 2005).

$4 \quad$ Zatímco preference supermarketů nebo diskontních prodejen jako hlavního místa nákupu potravin se v roce 2011 pohybovaly kolem $20 \%$ (supermarkety $18 \%$, diskonty $21 \%$ ), u hypermarketů se preference dostaly na své historické maximum: $44 \%$ pravidelně nakupujících potravinářské zboží v tomto typu prodejny (ČTK, 2012).

5 Jak ovlivní obchod internetová generace? Retail Info Plus 1-2/2013 [online]. Dostupné z: http://www.retailinfo.cz/plus/2013/1/?pn=18. 
impulzivní styl nákupu, typický prakticky pro celý poválečný evropský i zámořský vývoj (tamtéž). Tento styl postupně mizí v souladu se změnou myšlení lidí, kteř́ již přemýšlejí dopředu o tom, co chtějí či nechtějí koupit, a nikoliv jako dříve, kdy často zboží nejprve nakoupili a pak teprve uvažovali, co s ním. Hospodářská krize přivedla řadu zákazníků k opatrnosti, úsporám i menším nákupům. Není to ovšem vyvoláno pouze ekonomickými tlaky, ale také např. stále širším používáním internetu, kde je třeba mít předem rozmyšlen požadavek (nákup), na rozdíl od televizní reklamy, která podněcuje impulzivní nakupování. Nikoliv tedy reklama a další podněty, ale zákazník je stále více ten, kdo rozhoduje o realizaci nákupu. $\checkmark$ tomto prípadě lze hovořit o poměrně významném kulturním posunu, který lze brát pozitivně; negativem se může stát nižší objem nákupních košů v celém maloobchodu v důsledku omezení impulzivních nákupů.

Druhým trendem je orientace na hodnotu a kvalitu. Zvyšující se frekvence nákupů je dána také tím, že zákazníci častěji upřednostňují čerstvé potraviny a jsou ochotni pro ně denně docházet či dojiždět. Stále silnější pozici získávají v poslední době nákupy v akcích, promocích apod., kde ovšem nejde o nákup levného nekvalitního zboží, ale značkových výrobků za nižší cenu. Zákazníkům jde tedy skutečně o kvalitu, což otevírá možnosti v budoucnu dále rozšiřovat sortiment. Na druhou stranu zůstává samožrejmě velké množství lidí, kterým právě levné a nekvalitní zboží stačí a stačit bude i nadále.

Až hospodářská krize odezní, ustoupí obavy z budoucnosti a lidé budou opět ochotni nakupovat či obecněji utrácet peníze. Zákazníci se budou chtít vrátit $k$ tomu, o čem se přesvědčili, že pro ně má hodnotu, kvalitu. Již dnes se tak vytváří potenciál, aby kvalitní zboží a služby získávaly v pokrizovém období zákazníky stále častěji. Nová generace navíc vyrůstá v internetovém prostředí a je zvyklá uvažovat jinak. Aktivní sledování informací a jednoduchost a prímočarost mediální, resp. internetové komunikace mezi obchodníkem a zákazníkem budou rozhodujícími faktory potenciálního i reálného nákupu. Nákupní chování se posune od pasivity k aktivitě, od přijímání k vyhledávání.

Obchod patři aktuálně k nejrychleji se rozvíjejícím odvětvím, co se týče technologické podpory. $V$ blízkém horizontu několika let lze očekávat několik zásadních změn, inovací. ${ }^{6}$ Předně jde o samotný nákupní proces, kde dnes Ize využít jak standardní, tak samoobslužnou pokladnu. Do budoucna se hovoří o tzv. multichannel retailingu, který přinese daleko více možností, jak realizovat nákupní proces. Především se prostřednictvím dostupných prohlížečů (smartphone, tablet) rozširirí príprava z domova, zákazník si připraví elektronický nákupní seznam. V obchodě

6 Př́jemný nákup pro zákazníka, zvýšení efektivity pro obchodníka. Retail Info Plus 1-2/2013 [online]. Dostupné z: http://www.retailinfo.cz/plus/2013/1/?pn=18. 
si zákazník bude moci naskenovat položky, které si předpřipravil do mobilu, a zboží si odvézt. Nebo bude zboží rovnou nachystáno k odběru, resp. ho obchodník zaveze na určené místo. Již dnes se můžeme v některých regionech setkat (průkopníkem byla Jižní Korea) s tzv. virtuálními regály. Zákazník si zde nevybírá zboží on-line přes internet, jak je poměrně běžné, ale na snímcích vystavených na regálech $v$ „životní velikosti“ $v$ běžném supermarketu. Pomocí speciální aplikace si uživatel naskenuje přes mobilní telefon tzv. QR kódy daného zboží, to se načte do košíku a po zaplacení je toto zboží obchodníkem přivezeno domů.

Bude se také prohlubovat loajalitní systém sloužící k plnění přání a potřeb zákazníka v následujících dnech. Aby veškeré procesy a informace byly jednodušší a rychlejší, snaží se již dnes všechny řetezce o tzv. operational excellence, tedy o zlepšení efektivity v oblasti plateb, práci se skladem, využití zaměstnanců apod.

Další významnou proměnou nejen v oblasti technologie bude preference tzv. udržitelnosti, resp. prosazování „zeleného prístupu“. K tomuto přístupu patří jak nákup od lokálních a regionálních dodavatelü, který povede ke snižování zátěže životního prostředí, tak nákup produktů od důvěryhodných firem. $V$ neposlední řadě je třeba brát v potaz stále se prohlubující globalizaci v maloobchodě a expanzi nadnárodních řetězců na velké rozvíjející se trhy. Největší hráči tak budou globálně nakupovat nejen produkty, ale i technologie a služby.

\subsection{Prostorové aspekty transformace maloobchodní sféry}

Nákupní chování a s ním spojená prostorová mobilita jsou výsledkem vzájemného působení osobnostních charakteristik nakupujících (decision-makers) a podmínek okolního prostředí (Lentnek et al., 1976). Lidé žijící na jednom místě se mohou v rámci stejných podmínek chovat rozdílně z mnoha důvodů. Těmi mohou být jednak individuální potřeby a motivace, rozdílná míra informací týkajících se podmínek prostředí (spektrum a kvalita nabídky), ale také faktory v podobě takzvaných překážek - $k$ těm patří především finanční možnosti a prostorová mobilita (Lloyd, Jennings, 1978).

Nová dimenze velkoformátových řetězcových prodejen a nákupních center nejenže vytlačila dříve tradiční formy maloobchodu do pozadí zájmu nakupujících (Szczyrba, 2005), ale také výrazně změnila kulturní návyky spojené s nákupy u několika generací. Hovoříme zejména o nákupních centrech, která do značné míry zastoupila tradiční veřejný prostor se vším, co k němu patří (Voyce, 2006; Cooper, 2007; Jackson et al., 2011; Van Leeuwen, Rietveld, 2011). Postupem času se do nákupních center „vystěhovaly“ četné obchodní i neobchodní funkce z jednotlivých městských částí (stravování, pošty, banky, lékařské ordinace a další), a jak konstatuje Spilková a Hochel' (2009) nebo Pospěch (2010), nákupní centra v postsocialistických zemích se stala jedním z klíčových nositelů změny spotřebního 
chování společnosti. Nejen pro mladé lidi, ale i např. pro seniory v důchodovém věku se návštěva nákupního centra stává atrakcí, zábavou, trávením volného času, resp. jistou formou společenské události - být v "centru dění“ (např. Spilková, 2012a). Postupem času se tak začal vytvářet nový koncept nakupování, charakterizovaný až rekreačními atributy, podobně jako je tomu jinde $v$ zahraničí (Butler, 1991; Allen, 2005; Bäckström, 2006). Guy (1998) ve své klasifikaci spotřebitelského chování zdůrazňuje tzv. leisure shopping (rekreační nakupování) jako významnou formu současného široce chápaného procesu nakupování. Nákupní centra, zvláště jsou-li lokalizována do městských center (tzv. inner-city-developments), zvyšují svůj rekreační potenciál a determinují nový rozměr městského cestovního ruchu (Clark et al., 2003; Kowalczyk, 2005; Spilková, 2012a).

Města vždy plnila díky své obchodní funkci roli přirozených center nákupního cestovního ruchu, avšak donedávna výhradně se zřetelem na centrální lokality nabízející turistům-zákazníkům široké spektrum specializovaných prodejen. $\checkmark$ postindustriální fázi vývoje měst však dochází k jejich prostorově-funkční transformaci a ke vzniku nových městských center (Matlovič, 2000; Sýkora, 2001; Węcławowicz, 2003). Nákupní centra lokalizovaná na předměstích v dostupné dojížd'kové vzdálenosti od centra města (Garreau, 1992) spolu s dalšími aspekty (dojižz'kové a pracovní vazby, služby apod.) přispěla k modifikaci dlouholetého vnímání monocentrického funkčního uspořádání měst (Brown, 1992; England, 2000; Timothy, 2005 a mnoho dalších).

Uvedený trend logicky doprovázejí změny v pojetí a obsahu městského cestovního ruchu, který rozvojem velkých nákupních center dostává impulz. Existuje skupina autorů všímajících si tohoto fenoménu, avšak bud'to na úrovni prostého konstatování jevu (Kowalczyk, 2005), nebo na konkrétních př́kladech v Kanadě, USA a Evropě (Butler, 1991; Marjanen, 1995; Hahn, 1997; Severin et al., 2001), v Indii (Kuruvilla, Joshi, 2010), př́padně v Německu v nových spolkových zemích (Jürgens, 1994). Podstatně více prací je zaměřených na aspekty prostorových lokací a parametrické vyjádření obchodního potenciálu nákupních center pro praktické účely městského a prostorového plánování (Brandenburg, 1985; Brown, 1992; Guy, 1994; England, 2000; Crosby et al., 2005; Kok, 2007; Spilková, 2010; Spilková, Šefrna, 2010 a další).

Je zřejmé, že nakupování je dnes daleko složitějším a interdisciplinárním jevem, než tomu bylo v předchozím období, zejména pak ve vztahu k českým reáliím (obecně k situaci ve středoevropském regionu), kde se změny uskutečňovaly s daleko větší razancí než v zemích s tradicí tržní ekonomiky. Spektrum změn je relativně široké (viz dále), příkladem může být frekvence nakupování, která spolu s dojižd'kou za prací a do škol udává základní rytmus denního urbánního systému (Berry, 1967; Hall, 1974; Bezák, 2000). Stále silnější pozici získávají nepravidelné a víkendové aktivity rozličných populačních skupin, přičemž na rozdíl od denní dojižd'ky nebývá účel nákupu (zejména o víkendech) často primárním (Marjanen, 
1995; Mitríková, 2008). Jsme svědky zvyšujícího se podílu nedenní dojižd'ky za maloobchodem (obecně službami), která je vyvolána fungováním nákupních center a jiných velkoplošných maloobchodních prodejen na městských periferiích (tzv. out-of-town centers), jež se výrazným způsobem podílí na decentralizaci maloobchodních funkcí v urbánní struktuře a na vzniku polycentrického uspořádání měst (Knox, Pinch, 2000; Heineberg, 2006). ${ }^{7}$

Jak dále uvádějí ve své studii Mulíček et al. (2010), stává se maloobchod v období globalizace významným hybatelem změn v urbánních strukturách a patří $k$ důležitým rytmizátorům spotřeby ve městech. Nakupování v maloobchodních prodejnách je z hlediska konceptu geografie času (Hägerstrand, 1975; Pred, 1977; Miller, O’Kelly, 1983; Ira, 2001; Scott, He, 2012) jednou ze základních opakovaných aktivit člověka v časoprostoru. Z hlediska tohoto přístupu Ize pojímat nakupování jako formu frekvenční dojižd'ky za maloobchodem, v rámci které zkoumáme pohyb lidí do nákupních míst, jež stimulují poptávku spotřebitelů po nákupech a jiných doprovodných službách uspokojujících jejich potřeby. Intenzita a směry dojížd'ky jsou odstupňovány podle typu a lokace maloobchodních jednotek v urbánní struktuře, tj. v závislosti na stupňovitém uspořádání maloobchodní sítě, které koreluje s hierarchií frekvence uspokojování potřeb obyvatelstva zbožím denní, časté a občasné poptávky (Szczyrba, 2006).

\subsection{Motivační faktory nákupního chování}

Nakupování představuje $v$ dnešní společnosti jednu ze základních a nejobvyklejších forem sociálního jednání. Nákupní chování lze zkoumat z pohledu hned několika disciplín - psychologie, sociologie nebo také geografie. Zatímco psychologie spotřebitele vysvětluje nákupní chování člověka vzhledem k jeho hodnotovému systému a potřebám realizace, jako např. Maslowova hierarchie potřeb nebo typologie zákazníků (viz Vysekalová, 2004), sociologie zkoumá způsoby sociálního chování, jeho motivace nebo vliv médií a reklamy na nákupní chování, a to i v sídelně odlišných strukturách (např. město vs. venkov) nebo regionálních a jiných subkulturách (Schiffmann, Kanuk, 2004). Tento sociálně prostorový aspekt je pak

7 Velkoplošné maloobchodní prodejny na okraji měst jsou významnými ohnisky jejich dalšího rozrůstání. Téma suburbanizace je v geografii, sociologii či urbanismu velmi diskutovaným jevem, avšak vzhledem $\mathrm{k}$ zaměření příspěvku není tomuto tématu věnována další pozornost. Autoři odkazují na četné práce, které se fenoménu suburbanizace, ve vztahu k maloobchodu a jeho gravitačnímu působení, tzv. komerční suburbanizaci, věnují (např. Vogt, 1988; England, 2000; Matlovič et al., 2001; Ptáček, 2002; Sýkora, 2003; Matlovič, Sedláková, 2004; Ira, Andráško, 2008; Ouředníček et al., 2008; Fassmann, 2009 a další). 
předmětem behaviorální geografie, která se zabývá prostorovým vnímáním, rozhodováním a chováním (Hagget, 1965; Hägerstrand, 1975; Saarinen, 1976 a další).

Podle rozdílného chování rozděluje behaviorální geografie zákazníky na určité skupiny. O podobnou klasifikaci se pokusil např. Stone (1954 cit. in Walmsley, Lewis, 1984), který identifikoval čtyři skupiny spotřebitelů: spotřebitele, který se rrídí cenou, zákazníka, který je vázán zvykem a jenž dává přednost osobním kontaktům, zákazníka, který zastává etickou pozici, jako např. podporu malých obchodníků, a apatické spotřebitele, kteří se nezabývají tím, které obchody navštíví.

Sledujeme-li vztah nakupování a místa nákupư, zjištujeme, že ne vždy musí platit ekonomické důvody a racionální chování spotřebitelů. To vyvrací dříve přijímaný názor, že člověk upřednostňuje minimální mobilitu za nákupem a chová se veskrze ekonomicky (viz i např. výsledky výzkumů níže). Později se ovšem ukázalo, že část konzumentů si vybírá místo nákupů i podle jiných faktorů, tedy např. dle výběru zboží, dobré obsluhy, poskytování služeb, velikosti, atraktivnosti a atmosféry prodejny. Praxe ukazuje, že lidé často nerespektují logiku ekonomického myšlení a neřídí se striktně ekonomickými hledisky. Jak uvádějí Walmsley, Lewis (1984), pokud by v určité lokalitě města bylo vybudováno moderní velké obchodní středisko nabízející služby na úrovni, široký sortiment, dobré ceny apod., zdaleka ne všichni lidé z okolí by zde nakupovali. Naopak bylo by možné v daném místě pozorovat nakupující z relativně vzdálených lokalit. Ukazuje se, že nakupování je ovlivňováno řadou faktorů časově i prostorově proměnlivých a že je poměrně složitým sociálním jevem.

Jiným neméně důležitým aspektem je vztah mezi prostorovou strukturou maloobchodního prostředí a mezi spotřebitelským chováním, který současně vytváří základ konceptu behaviorální geografie (Lunch, 1960; Pred, 1977). Dříve se předpokládalo, že člověk upřednostňuje minimální mobilitu za nákupem a chová se ve prospěch ekonomické přirozenosti. Později se ale ukázalo, že část konzumentů si vybírá místo nákupů i podle jiných faktorů, např. podle výběru zboží, dobré obsluhy, poskytování služeb, velikosti, atraktivnosti a atmosféry prodejny - chovají se tedy iracionálně (Walmsley, Lewis, 1984).

Velmi často se ve výzkumech týkajících se spotřebitelského chování uplatňuje také klasifikace podle účelu nákupu. Guy (1998) rozlišuje tzv. běžné nákupy (convenience shopping), které směřuji do center se supermarkety či jinými menšími obchody s potravinami. Nákupy pro domácnost (household shopping) se realizují především ve velkých nákupních centrech. Osobní nákupy (personal) /fashion shopping) představují více prohlížení výkladů a porovnávání sortimentu, tudíž jsou spojeny spíše se specializovanými obchody v městských centrech nebo s nákupními pasážemi nákupních center.

Dalším významným druhem je rekreační nakupování (leisure shopping), při kterém jsou preferována atraktivní nákupní centra lokalizovaná v centru či na periferii, factory outlet centra apod. Při rekreačním nakupování je motivace zákazníka 
orientována na uspokojování potřeb spotřebitelů v „nezávazném“ procházení po pasážích a obchodech, vnímání atmosféry obchodů či v sociálních kontaktech s dalšími lidmi. Je to určitá forma trávení volného času. Procházení obchodů může také často vést $\mathrm{k}$ impulzivním nákupům, a tedy zvýšeným obratům pro obchodníky. Nahodilé nákupy (incidental shopping) jsou charakteristické pro dojiždějící a často cestující osoby. Spojujeme je s drobnými obchody, ale i s většími jednotkami nacházejícími se zejména v blízkosti či jako součást různých dopravních terminálů (nádraží, letiště). Často se však setkáváme se zjednodušenou klasifikací na účelové nakupování (purpose shopping), rekreační nakupování a stále častější víceúčelové nákupy (multipurpose shopping). Účelové nakupování je většinou předem naplánováno a orientuje se na cenu a dostupnost zboží. Při víceúčelových nákupech si spotřebitel vybírá skupinu obchodů tak, aby minimalizoval celkové náklady a zároveň získal potřebné zboží a služby (Spilková, 2012a).

Složitost rozhodování spotřebitelů ve vztahu k obchodní nabídce v území byla $v$ minulosti předmětem konstrukce řady modelů. Každý z nich má svá docenitelná pozitiva, umožňující pochopit některé aspekty složitosti nákupního chování. Jedním z prvních a nejznámějších je model navržený Huffem (Huff, 1964), který znázorňuje proces rozhodování konzumenta s přihlédnutím $k$ velikosti prodejny a době cesty do obchodu. Jak uvádějí Walmsley, Lewis (1984), hlavním nedostatkem modelu je, že popisuje chování spotřebitelů ve specifických situacích a není jisté, zda ho lze použít v jiných podmínkách.

Dalším pokusem o zobecnění vztahu mezi nákupním chováním spotřebitelů a obchodní nabídkou byl výzkum Rushtona (1969), jehož základem bylo poznání prostorových preferencí míst nákupů a jejich třídění do určitých typů lokalizace obchodních středisek. V návaznosti na předchozí autory Potter (1979) analyzuje způsoby získávání informací o maloobchodní nabídce $v$ okolí místa bydliště a syntetizuje poznatky do konstrukce tzv. informačního pole. $V$ něm pak rozlišuje pole informací o prodejnách, které však zákazník nevyužívá, a pole využití, čili kde se nacházejí místa realizace nákupů. Tato druhá užší výseč (realizační) leží uvnitř první výseče (informační), a ta je tím širší, čím vyšší je společenský status zákazníků. Nákupní chování je tedy složitý proces skládající se ze získávání, zapamatování a využití informací pro utváření rozhodovacích schopností.

Jak zdůrazňuje Spilková (2003), spotřebitelské chování nelze zjednodušit a shrnout do obecného modelu, a hovoří o modelu utváření nákupního chování vlivem nástupu konkrétních změn $v$ odvětví maloobchodu a v maloobchodní síti. Popisuje proces formování nákupního chování v transformujících se ekonomikách jako přechod mezi jednotlivými fázemi organizace společnosti a ekonomiky, tj. přechod od socialismu přes počátky rozvoje tržní ekonomiky po fázi tržně se vyvíjející ekonomiky. Nákupní chování není jen opakující se neměnná činnost, ale prochází procesem formování. Spotřebitel podstupuje proces prostorového hledání předtím, než nasbírá potřebné informace o maloobchodních 
přiležitostech, aby z nich mohl postupně vyřadit ty, které jsou pro něj nevýhodné (Shepherd, Thomas, 1980; Golledge, Stimson, 1997 cit. in Spilková, 2003).

Maloobchod ve 2. desetiletí 21 . století s sebou přináśí i významné změny, které se dotýkají využívání nových informačních a komunikačních technologií jako motivačních faktorů pro uskutečnění nákupu. Stále sice převažují standardní formy nákupů, ale v kontextu zavádění moderních technologií již existují, a do budoucna se budou dále rozšiřovat, nové motivační prvky. Jedním z důležitých předpokladů využití řady novinek na trhu bude jejich prímá vazba na dnes již běžně používaná zařízení, jako jsou smartphony či tablety.

$\mathrm{Na}$ českém trhu je již v současnosti možné využít např. samoobslužných pokladen, které ve vybraných prodejnách používají společnosti Ahold, Globus, Kaufland, Tesco a Ikea. Jedná se zatím o řešení při menších nákupech do 15 položek, někdy se označují taky termínem scan and bag. Dva obchodní řetězce začnou toto zařízení používat v supermarketech o velikosti zhruba $1000 \mathrm{~m}^{2}$ a očekává se další rozvoj samoobslužných pokladen u velkoformátových konceptů. Vytíženost těchto zařízení se zatím pohybuje mezi $10-50 \%$ podle nákupního času ve špičce. Horkou novinkou je automatické skenování, resp. 360stupňový skener ve tvaru rámu, který umí až 60 skenů za minutu a formou automatického nákupního pásu tak zásadně zrychlí odbavení zákazníka. Zatím existují v Evropě pouze tři implementace $v$ rámci pilotních projektů.

Rozmáhá se také platba bezkontaktními platebními kartami, které motivuji zákazníka ušetřením času při zadávání PIN kódu a vǔči tvořícím se frontám. Jedná se zatím o speciální platební karty označené originálním logem a bez zadávání PINu s ní lze provést nákup do 500 Kč. V roce 2012 si bezkontaktní karty VISA pořídilo v České republice asi 600 tis. osob. Karty nabízí již řada bankovních ústavů (Komerční banka, ČSOB, Česká spořitelna, GE Money Bank a další), odběr je možno provést na více než 15 tis. terminálech (např. Lidl, Penny Market, Kaufland, Globus, Žabka, IKEA, OBI).

Využití smartphone je teprve na začátku. $V$ blízké budoucnosti se ovšem formy nakupování prostřednictvím mobilního telefonu (mobilní nakupování) budou skloňovat častěji. Smartphone či tablet umožní zákazníka informovat o daném produktu, o akčních cenách $v$ daném obchodě, aktuální nabídce slevových kuponů apod. Dalším zákaznickým motivátorem jsou věrnostní systémy. V současné době jsou tyto systémy založeny na velkém množství dat, v budoucnu bude třeba těmto datům rozumět a umět z nich vyčíst nákupní zvyklosti zákazníků a podklady pro prostorové, sortimentní a další úpravy obchodu. 


\subsection{Nákupní centra, rekreační nakupování a volný čas}

Předchůdci nákupních center byly obchodní domy, jejichž koncept znamenal skutečnou revoluci ve způsobech nakupování. Obchodní domy a pozdější obchodní či nákupní centra se staly jedním z nástrojů hlubších společenských a ekonomických změn, jež znamenaly obrat od nákupů z „nutnosti“ k nákupům pro zábavu. Lidé se mohli začít odlišovat, zvýraznila se jejich osobní identita a začaly být uspokojovány více než pouze základní lidské potřeby (Schiffmann, Kanuk, 2004). Obchodní domy byly totiž od druhé poloviny 19. století poprvé otevřeny pro všechny společenské vrstvy, přičemž zákazníci se mohli volně procházet, vybírat či pouze prohlížet zboží. Převratnou novinkou byla možnost vrácení zakoupeného zboží či první slevové akce (Klaffke, 2003; Coleman, 2006). K rozšíření konzumního způsobu života pomohla také rostoucí kvantita i kvalita sériově vyráběného zboží a jeho dostupnost širším společenským vrstvám (Timothy, 2005), což v modernější podobě setrvalo prakticky dodnes.

Klasifikovat nákupní centra je poměrně složité, neexistuje totiž jednotná shoda na kritériích či kategoriích třídění. Lze je klasifikovat z několika hledisek, např. podle velikosti, uspořádání, vlastnictví, účelů nákupních cest do nákupních center nebo klasifikace na základě centrality v rámci obslužných funkcí. Velmi důležitým třídicím prvkem je samotná lokalizace nákupních center; zde pak rozlišujeme tzv. edge-of-centre, out-of-centre a out-of-town nákupní centra (Guy, 1998; England, 2000).

Zjednodušeně lze tedy nákupní centra rozdělit na ta, která fungují ve vnitřní funkční struktuře měst, a centra $v$ periferní poloze či v těsné blízkosti měst. Prvně jmenovaná centra svojí nabídkou i cenou zboží a služeb odrážejí faktor polohové renty a výši vstupních nákladů - jedná se o vnitroměstská nákupní centra vyšší cenové úrovně vzniklá často $v$ procesu revitalizace opuštěných či jinak deprimujících ploch bývalých areálů továren a vlakových nádraží. Matlovič (2000) či Šveda, Križan (2012) považují výstavbu nákupních center v blízkosti zastavěných ploch uvnitř města za typický projev komercionalizace. Na druhou stranu hlavní výhodou lokalizace periferních nákupních center je dostatek místa pro rozvoj obchodních i neobchodních ploch včetně těch relevantních pro fungování nákupních center (dopravní infrastruktura, parkoviště). Zde je potom možné hovořit o komerční suburbanizaci (Šveda, Križan, 2012).

Nákupní centra tedy nejen generuji široký vnější i vnitřní nákupní spád, ale svou nabídkou obchodních i neobchodních funkcí také vyvolávají zvýšený cestovní ruch směrem do míst jejich lokací. Svou podstatou se tak nákupní centra $v$ dnešní době významně podílejí na rozvoji nových forem městského cestovního ruchu a rekreace a zásadním způsobem mění dosavadní pohled na současný městský cestovní ruch, resp. na cesty do měst za účelem nakupování (Szczyrba, 2002; Timothy, 2005). 
Z hlediska provozování nákupních center a jejich úspěchu je velmi důležitý mix nájemců působících v objektu centra. Dřive byly páteří nákupních center obchody s potravinami. S rozvojem decentralizovaných nákupních center nastoupil ale nový trend a mnoho jich začalo fungovat jako společenská a zábavní centra a jako místa setkávání lidí. Začala nabízet celou řadu non-retailových aktivit, jakými jsou rekreační a zábavní zařízení (multikina, různé akce pořádané pro zákazníky v rámci marketingových aktivit apod.) a provozovny pro sportovní vyžití (fitness, bazény, kluziště a další). Současná nákupní centra zaměřená především na kombinaci obchodu a zábavy označuje Dudek-Mankowska, Križan (2010) za centra 3. a 4. generace (na rozdíl od center 1. a 2. generace orientovaných primárně na obchod a služby).

Prostředí nákupních promenád či nákupních galerií (shopping malls) umožňuje lidem nejen uspokojit jejich nákupní potřeby, ale dává prostor pro naplnění potřeb estetických (vizuálních) a společenských - být tzv. v centru dění, střetávat se s druhými, prezentovat svůj sociální status či jen tak „zevlovat" a sledovat ruch kolem sebe (Bauman, 1996). Samotný pohyb zákazníků po nákupním centru také není nahodilý, ale řídí se stanovenými pravidly jeho uspořádání. Přesněji řečeno, nákupnímu chování zákazníků je přizpůsobeno uspořádání center, které vychází $z$ dlouhodobých zkušeností $s$ jejich provozem a bývá aktuálně modifikováno podle potřeb. Před vstupem do hypermarketu, př́padně do jiných velkoprodejen, se zákazníkům „představuje“ nákupní galerie s desítkami menších specializovaných obchodů, restaurací apod. Většina nákupních center tak působí víceméně stejným sterilním a uniformním dojmem, který dovoluje ve své podstatě stereotypní plánování jejich dalšího rozvoje (Brown, 1992; Spilková, 2003). Rozdíly jsou pouze ve velikosti center, která determinují rozsah poskytovaných služeb s ohledem na potenciální nákupní spád.

Obecně Ize rríci, že poznání vzorců chování spotřebitelů je v současném pojetí retailingu klíčovou otázkou maloobchodního podnikání, a to jak při lokaci, tak rovněž při organizaci a fungování retailových provozoven na všech jejich velikostních a provozních stupních. Každý prodejce potřebuje znát své klienty, proto také cíleně využívá data klientů (údaje z věrnostních karet, dotazování na pokladnách, výzkumy spotřebitelského chování realizované profesionálními agenturami apod.) pro další plánování v rámci firemního marketingu a managementu. Sledování zákazníků je předmětem sofistikovaných behaviorálních výzkumů, které analyzují nejen nákupní zvyklosti spotřebitelů s cílem jejich typologie (na základě pohlaví, věku nebo sociálního statusu), ale monitorují také pohyby nakupujících po nákupních centrech (pomocí kamerového systému). Ukazuje se, že tyto pohyby nejsou nahodilé, ale organizované (Brown, 1992; Spilková, 2003; Spilková, Hochel', 2009). Právě velká nákupní centra poskytují vhodný prostor pro výzkumy umožňující detailněji poznat variety spotřebitelského chování, které se neustále vyvíjí vlivem průběžně se transformujícího maloobchodního prostředí (Kopale, 2010; Trivedi, 2011). 


\subsection{Dojížd'ka za maloobchodem, výběr středisek a spádových oblastí}

Dojižd'ka za maloobchodem představuje významný aspekt obslužné funkce sídel (Haggett, 1965; Berry, 1967). Vybavenost sídel maloobchodem determinuje velikost obsluhovaného území a ostatní parametry funkcí územně obslužných systémů. Na rozdíl od dojižd'ky do zaměstnání a škol nejsou údaje o dojižd'ce za službami dostupné z žádného oficiálního statistického zdroje, nesleduje je ani sčítání lidu, domů a bytů. Pro posouzení tohoto fenoménu, př́p. pro srovnání změny ve spádovosti, dojížd'kových směrech, sférách vlivu a síle středisek apod. je třeba provádět opakované výzkumy, nejčastěji formou anketního (dotazníkového) šetření či interview. Jen ty nabízejí možnosti srovnání, i když dnešní stav prostorové organizace maloobchodní sítě je, vzhledem k novým prodejním konceptům a jejich vlivu na utváření spotřebitelského chování, nesrovnatelný se stavem např. pred čtvrtstoletím.

Podle Maryáše (1983) Ize při výběru středisek obslužné sféry a hodnocení jejich hierarchické úrovně použít tyto metodické přístupy:

i) vymezení středisek na základě údajů o funkci, kapacitě a využití zařízení maloobchodu a služeb v sídlech - tzv. statické charakteristiky využívající dat standardně zjištovaných statistickými úřady;

ii) vymezení středisek na základě velikosti obsluhovaného území, tedy na základě obslužných procesů mezi sídly - tzv. dynamické charakteristiky používající data z anketních šetření spádovostí obyvatelstva za obslužným vybavením sídel (Smailes, 1967 cit. in Maryáš, 1983; Scott, 1973).

První způsob detekce interakcí mezi obslužným střediskem a jeho zázemím je vzhledem k absolutnímu nedostatku relevantních údajů o kapacitách maloobchodní sítě dnes prakticky nerealizovatelný. ${ }^{8}$ Druhý ze způsobů vymezování středisek je založen na dynamice vztahů středisko-zázemí. Údaje o spádovosti (dojižd'ce) obyvatel za občanskou vybaveností (obchodem a službami) se používají nejen pro výběr středisek, ale především pro určení dimenze spádových území jednotlivých středisek a zjištění intenzity vztahů mezi střediskem a zázemím (Maryáš, 1983, 1988).

Při vymezování sfér vlivu středisek na základě anketních šetření se používají dva způsoby:

i) anketou ve vybraných zařízeních obslužné sféry vybraného střediska (např. Wokoun, 1983);

ii) anketou ve všech sídlech zkoumané oblasti (např. Maryáš, 1988). údajů o maloobchodní vybavenosti území, např. počet prodejen, sortimentní struktura nebo maloobchodní obrat. Tyto údaje ovšem nejsou dnes předmětem českého statistického výkaznictví pro odvětví maloobchodu (služeb), jako tomu bylo před rokem 1989. 
Většina výzkumů založených na anketních šetřeních uvádí, že v podstatě v každé hierarchické úrovni existuje zóna intenzivní dojižd'ky, zóna slabší dojižd'ky a oscilační zóna (např. Berry, 1967). Při anketních šetřeních ve vybraných zařízeních střediska je však problematické stanovení kritérií, kterými určujeme rozsah spádového území i intenzitu vazeb.

Anketní šetření je metodou málo frekventovanou, časově a logisticky velmi náročnou, přičemž jde zejména o vystižení podstaty fungování nákupních center či vnitroměstských středisek maloobchodní vybavenosti a generování jejich sfér vlivu. $V$ aplikační rovině se potom autoři, většinou na konkrétních príkladech, snaží popsat model nákupního chování dané populace vzhledem $\mathrm{k}$ výběru míst jejích nákupů (Coshall, 1985; Timmermans et al., 1982; Bacon, 1995; Marjanen, 1995; Findlay et al., 2001; McEachern, Warnaby, 2006; Jackson et al., 2011).

$\checkmark$ České republice se šetřením dojižd'ky za maloobchodem, resp. nákupním spádem založeným na dotazování respondentů nezabývalo př́liš mnoho autorů. Pokud se v minulosti nějaká zjištování uskutečnila (např. Výzkumný ústav obchodu Praha, Univerzita Karlova Praha, Geografický ústav ČSAV Brno), tak vždy jen na omezených modelových územích. Tradici výzkumů v tomto oboru hledejme zejména v pracích pocházejících z bývalého Geografického ústavu ČSAV, kde mezi nejcitovanější autory patří především Maryáš (1983, 1988, 1992). Ten ve své ojedinělé práci z roku 1988 zhodnotil, pomocí rozsáhlého anketního šetření z přelomu 70. a 80. let, geografické aspekty rozmístění maloobchodu a komunálních služeb v ČSSR (na Slovensku ve spolupráci s Geografickým ústavem SAV) s důrazem na výběr nadmístních středisek a vymezení jejich sfér vlivu. Toto šetření bylo provedeno přes soustavu MNV a MěNV, kdy tajemníci národních výborů byli dotazováni na hlavní i vedlejší cíle obyvatel sídla při nákupech potravin, běžného textilu a obuvi, průmyslového zboží (elektrospotřebičů), léků, knih, nábytku, speciálního výběrového zboží a při návštěvách běžných a speciálních služeb. $Z$ hlediska územního členění byly údaje o spádovosti zjištovány za každou místní část obce (kromě krajských a hlavních měst).

Na základě údajů z již zmíněného anketního šetření Geografického ústavu a na základě údajů ze sčítání občanské vybavenosti 1981 zpracoval Maryáš (1988) studii o střediscích maloobchodu a služeb, která vymezuje střediska základní obsluhy (v ČSSR 419) a základní obslužné regiony (ZOR). Tyto regiony představují rámec, $v$ němž jsou relativně uzavřeny nadlokální obslužné procesy, jako jsou nákupy běžného textilu a obuvi, běžného průmyslového zboží, léků, knih, nábytku a návštěvy běžných a speciálních služeb. Přestože Maryášův př́stup k řešení územně obslužných vztahů a jejich regionalizaci ve své práci kriticky zhodnotili Hampl et al. (1987), a to zejména s ohledem na způsob získávání dat pro územní analýzy, je tato metoda podložena solidním teoreticko-metodologickým aparátem a jako takovou ji Ize považovat za vědecky seriózní. Před rokem 1990 tak autor vytvořil 
unikátní srovnávací platformu, na kterou se, vzhledem ke značné obtižnosti získání srovnatelných dat, bude jen velmi těžko navazovat. ${ }^{9}$

Na stejné metodické bázi (anketní šetření) byl dřive proveden výzkum srovnávající změnu hraničních bodů sféry vlivu v Jihomoravském kraji (Brno a sousední menší jádra), autorů Kroce a Ševery (1974), anketu vymezující zázemí středisek okrskové a vyšší vybavenosti aplikoval na Ostravu, resp. Hradec Králové Ryšavý (1970, 1980). Z autorů, kteří se ve svých výzkumech věnovali Brnu a jeho zázemí, je třeba jmenovat Wokouna $(1981,1983)$, který vymezil nejdřive spádové území města Brna, v druhém případě nákupní spád do obchodního domu Prior. Podobnou metodiku využil ve své práci věnované brněnské aglomeraci také Vaishar (1983).

Na konci 80. let minulého století vznikla řada kvalitních prací (i diplomových) řešících potřebu optimalizace výhledového rozvoje maloobchodní sítě (např. Krásný, 1989; Drtina, Krásný, 1989) či otázky regionální organizace maloobchodního systému (Krásný, 1985; Sýkora, 1988; Drtina, 1989). Praktické vymizení datové základny po roce 1990 znamenalo publikačně hluché období, které na přelomu století oživují práce orientované na kauzální prostorové vztahy transformace maloobchodu (často na příkladu vybraných měst a obchodních zařízení), kde autoři využívají také anketní formu šetření (Tonev, 1998; Szczyrba, 2002) či první případové studie sledující nákupní chování obyvatel v novém fenoménu nákupních center (Spilková, 2003).

V letech 2004-2006 bylo provedeno anketní šetření na území moravských krajů, které organizovala Univerzita Palackého v Olomouci ve spolupráci s Masarykovou univerzitou Brno (viz Szczyrba et al., 2005). Metodicky navazovalo na dotazníkové šetření Geografického ústavu ČSAV z minulého století a bylo provedeno i parciální srovnání výsledků obou šetření na území NUTS 2 Jihovýchod (Mašíček, 2007), i když sféry vlivu obslužných středisek nebyly vymezovány zcela identicky.

Při hodnocení jak geografických, tak sociologických aspektů nákupního spádu do středisek obslužnosti, nákupních zvyklostí, příp. jejich změn, se středem pozornosti stávají v posledních letech modelové velkoplošné maloobchodní prodejny a vznikající nákupní centra (Smolová, Szczyrba, 2000; Spilková, 2003; Ordeltová, Szczyrba, 2006; Mulíček, 2007; Kunc et al., 2012b, 2012c, 2012d, 2012e). Začínají se ovšem objevovat i studie řešící mj. environmentální dopady výstavby velkoplošných konceptů na území (Koželuh, 2010; Spilková, 2010; Spilková, Perlín, 2010).

$9 \quad$ Prakticky nebude možné realizovat podobné územní analýzy, budou-li i nadále služby stát mimo zájem statistického výkaznictví. Chybí zejména územní detail zjištovaných údajů o službách (maloobchodě). Jediné další celorepublikové šetření maloobchodní sítě z roku 1999 (Retail Cenzus 1999) nemělo potřebnou vypovídací hodnotu (odlišná metodika sčítání, nesrovnatelná územní podrobnost publikovaných výsledků apod.). 
Autorem první tuzemské práce věnované vývoji a transformaci maloobchodní sítě s přesahem k nákupnímu chování obyvatel, s př́ipadovou studií podpořenou anketním šetřením při zjištování spádovosti obyvatel za maloobchodem, je Szczyrba (2005). Nově jsou poznatky o dalším vývoji v české i zahraniční maloobchodní síti s ukázkami několika především sociologicky (kvalitativně) zaměřených výzkumů shrnuty v publikaci Spilkové (2012), v níz se autorka kromě jiného věnuje nákupnímu chování a nákupnímu centru jako novodobému prostorovému a společenskému fenoménu $v$ kontextu vybraných ekonomicko-sociálních aspektů spotřebitelské společnosti.

Blízké slovenské maloobchodní prostředí posledních let, také v souvislosti s nákupním spádem obyvatel do hypermarketů a nákupních center a změnami v nákupním chování obyvatel, představují ve svých pracích Fert́alová (2006), Lauko et al. (2008), Mitríková (2008), Križan et al. (2009) či Trembošová (2010). Za zajímavé pro českého čtenáře lze považovat také některé studie německých autorů, kteři se věnují detailnímu hodnocení nákupního spádu a nákupního chování spotřebitelů (Kulke, 1992), popř. analyzují fungování nákupních center v regionech bývalého východního Německa (Jürgens, 1994).

\subsection{Modelování prostorových interakcí, gravitační modely}

Teoretická východiska a historický vývoj modelování prostorových interakcí podrobně rozebírají např. Sheppard (1978), Senior (1979), Haynes, Fotheringham (1984), Fotheringham, O'Kelly (1989), Pooler (1994), Fotheringham et al. (2000), či Wilson (2010), zde však stručně představíme také milníky v jejich vývoji. Modelování toků a pohybů v humánní geografii bylo inspirováno fyzikou (Newtonovým zákonem univerzální gravitace) a první práce využívající fyzikální analogie v geografii se objevily již koncem 19. století (Ravenstein, 1885). Pro naše využití jsou však z hlediska historického nejdůležitější práce Williama Reillyho (1929, 1931), který se zabýval spádovostí oblastí k centrům v oblasti maloobchodu, vlastně tedy modeloval maloobchodní dojižd'ku. V české geografii aplikovali Reillyho model v různých úlohách Řehák (2004), Hubáčková, Krejčí (2007), Řehák, Halás, Klapka (2009) a Halás, Klapka (2010).

Důležitým mezníkem v oblasti modelování prostorových interakcí byly práce Allana Wilsona $(1967,1974)$, který opustil jednoduchou newtonovskou formulaci interakčních modelů a tzv. skupinu či „rodinu“ interakčních modelů založenou na maximalizaci entropie. Zavedením omezení do výchozí situace pak dostáváme čtyři typy modelů prostorových interakcí (Wilson, 1974). Podobný přístup vycházející vždy z fyziky či matematiky zvolili i Snickars, Weibull (1977), Alonso (1978) a Tobler (1983). Teprve koncem 80. let 20. století byla opuštěna fyzikální inspirace pro modely prostorových interakcí (Fotheringham, O’Kelly, 1989; 
a posléze Fotheringham et al., 2000) a modelování interakcí vycházelo z behaviorálních přístupů, kdy se za základ považuje tzv. diskrétní prostorová volba jednotlivce mezi navzájem si konkurujícími destinacemi a hierarchické zpracování informací.

Modely prostorových interakcí obecně vycházejí z předpokladu, že intenzita prostorových interakcí se zvyšuje s měřítkem lokací (tedy s jejich kvantitativním nebo kvalitativním významem, velikostí či masou) a snižuje se se vzdáleností, která lokace odděluje. Tedy interakce $\left(T_{i i}\right)$ mezi dvěma lokacemi $i$ a $j$ je funkcí míry $v$ emitivity (také produktivity) lokace $i$, míry $w$ atraktivity lokace $j$ a míry $d$ vzdálenosti mezi lokacemi $i$ a $j$ :

$$
T_{i j}=f\left(\mu v_{i} ; \alpha w_{j} ; \beta d_{i j}\right)
$$

kde $\mu, \alpha, \beta$ jsou parametry zohledňující vztah proměnných $v, w$ a $d$ k interakčnímu vzoru.

Nejdůležitější roli hraje při modelování prostorových interakcí vzdálenost, respektive funkce poklesu interakce se vzdáleností. Tyto funkce mají většinou nelineární tvar (Taylor, 1971; Johnston, 1973; Wilson, 1974; Sheppard, 1978). Nejčastěji jsou využívány negativní paretovská funkce, exponenciální funkce nebo funkce složené s různými hodnotami parametrů. Roli vzdálenosti a funkcím poklesu intenzity se vzdáleností se věnují napríklad Taylor (1971), Cliff et al. (1974), Wilson (1974), Fotheringham (1981), De Vries et al. (2009), v české geografii pak Halás, Klapka (2012).

V dávnější minulosti, kdy nebyla k dispozici data o dojížd'ce za službami a konkrétně za maloobchodem, se určovalo zázemí obchodních středisek (nebo také sfér vlivu) prostřednictvím gravitačních modelů. Jedním z nejstarších je tzv. Reillyho model maloobchodní gravitace, který byl Stewartem (1948) označen za první případ rozpoznání a aplikace demografické gravitace. Počátky použití gravitačních modelů pro vymezení spádových území nákupních, resp. obslužných středisek můžeme datovat do 20 . let minulého století, kdy na základě anketního šetření prováděného v Texasu formuloval Reilly $(1929,1931)$ tzv. zákon maloobchodní gravitace - později nazývaný Reillyho zákonem - takto: v normálních podmínkách dvě města, která jsou středisky maloobchodu, přitahují nakupující z okolních sídel přímo úměrně síle počtu obyvatel těchto měst a nepřímo úměrně síle vzdálenosti každého $z$ těchto měst $\mathrm{k}$ okolním sídlům. Model byl dále doplněn Conversem (1949) a Huffem (1964).

Původně byl Reillyho model zkonstruován za účelem zjištóvání spádovosti za maloobchodem a vycházel z čistě formálních vztahů. Model byl aplikován především při stanovování tendencí obyvatelstva dojiždět za různými typy služeb do zvolených středisek a také při identifikaci rozhraní vlivů středisek v rámci jednoduchých grafových schémat systému osídlení (např. Fotheringham, O’Kelly, 
1989). Nejčastěji se tedy mimo gravitační modely využívají také modely mezilehlých príležitostí (vývoj koncepcí např. Isard et al., 1998).

Pozdější vývoj vedl k zavedení pravděpodobnostního konceptu a rozšíření počtu středisek (pưvodní Reillyho model dovoloval rozdělit území jen mezi dvě střediska). Rovněž dochází ke zevšeobecnění proměnných, přičemž např. Wilson (1974) zavádí místo počtu obyvatel sídla tzv. produkční proměnnou, což je v podstatě úroveň poptávky $v$ sídle, a tzv. proměnnou atraktivity, což je úroveň nabídky ve středisku, a rovněž vzdálenost je nahrazována tzv. generalizovanou dopravní funkcí. Ve středoevropských sídelních poměrech se nejčastěji používá tzv. Huffův model, resp. jeho zjednodušená varianta typově patřící do skupiny gravitačních modelů s omezením, kdy nahrazujeme proměnnou atraktivity zástupnou proměnnou, např. počtem druhů obslužných zařízení, počtem zaměstnaných v maloobchodě, resp. ve službách, prodejní plochou nebo maloobchodním obratem (viz např. Maryáš, 1983).

V pozdější době poukázal např. Löffler (1998) na různý průběh funkce vzdálenosti u rozdílných velikostí středisek, kdy největší střediska mají častokrát funkci vzdálenosti s inflexním bodem a větší „spodní plochou (plocha pod funkcí vzdálenosti určuje počet klientů nebo zákazníků centra). Löffler dále podává detailní přehled možných vstupních dat do Reillyho modelu, a to dat týkajících se masy i vzdálenosti.

V české odborné literatuře pak Reillyho model diskutují ve svých pracích např. Maryáš (1983), Řehák et al. (2009) či Halás, Klapka (2010). Maryáš (1983) kriticky hodnotí způsoby vymezování sfér vlivu středisek maloobchodu, především v souvislosti s platností původních modelů na území Československa, přičemž závěry učiněné na základě studia zázemí Brna a Prahy odpovídají zahraničním zkušenostem. Halás, Klapka (2010) již poukazují na možné aplikace Reillyho modelu kromě maloobchodu i na obecnější a aktuální výzkumná témata.

Studií, které by se věnovaly prímo vymezování spádových regionů na základě reálné dojižd'ky za službami, není ve světové vědecké literatuře př́liš mnoho. Mezi klasické patři práce Berryho (1967), který se zaměřil na spádovost za službami na př́kladu maloobchodních center ve vybraných amerických městech. Berry se později pokusil své poznatky zobecnit i pro jiné regionalizační úlohy.

Pozměněným typem výzkumu, který je pro nás vzhledem k zaměření publikace nosnější, je vymezování spádových oblastí nákupních center (tedy nikoliv sídel/středisek - např. Lee, Pace, 2005; Baray, Cliquet, 2007). Zde je nutné poznamenat, že zmiňované práce často nejsou jen produktem geografů, ale také prostorových ekonomů. Lee a Pace (2005) se např. zabývají prostorovou distribucí maloobchodního obratu mezi nákupní centra v souvislosti s jejich vzájemnou lokací na príkladě amerického Houstonu; v jiné studii Baray a Cliquet (2007) diskutují o možnostech matematické morfologické analýzy pro vymezování zázemí nákupních center. 



\section{Základní metodický přístup k provedeným šetřením}

Převážná část empirických studií zmiňovaných v předchozím textu se metodicky opírá o anketní (dotazníková) šetření jako nejrozšířenější metody kvantitativního výzkumu (Flowerdew, Martin, 2004). Nejobvyklejším způsobem získávání dat ve výzkumech nákupního spádu do vybraných velkoplošných maloobchodních jednotek je přitom i) metoda dotazování se respondentů prímo $v$ hypermarketech a nákupních centrech nebo v jejich blizkosti (obvykle parkoviště), kdy jsou jim kladeny otázky směřující ke zjištění spádových poměrů, frekvence nákupů, preference míst nákupů apod. Jinou strategii aplikoval Maryáš (1983), který vzhledem k rozsahu zájmového území (celá Česká republika) použil metodu ii) dotazování starostů obcí (obecně lokálních lídrů), jejichž výpovědi měly nahrazovat jinak nedostupné údaje o jednotlivcích bydlících na území dané obce. Je nutné zdůraznit, že Maryášův výzkum byl realizován na úrovni základních sídelních jednotek, což je z hlediska administrace a rozsahu šetření z dnešního pohledu takřka nepředstavitelné. Pro rozsáhlejší území je alternativou také iii) dotazování prostřednictvím učitelů, resp. žáků základních škol.

Další možností je iv) dotazníkové šetrení realizované s respondenty přímo $v$ jejich domácnostech. Metodicky se jedná patrně o nejspolehlivější postup s nejkorektnějšími výsledky. Jeho hlavním omezením jsou však vyšší časová náročnost a menší prostorový záběr (tento přístup je aplikován např. pro výzkum v rámci jednoho města či obce). Obměnou pro městský prostor může být v) dotazování na ulici, jež umožnilo méně formální rozhovor a tazatel byl schopen jeho průběh urychlit. Šetření nebylo vázáno pouze na rezidenty, ale i na dojiždějící za prací, do škol a za službami.

Podle účelů a zaměření našich výzkumů jsme volili jednotlivé způsoby šetření i jejich kombinace (kromě dotazování přes základní školy). Pro šetření v zázemí Brna, ve vazbě na denní a nedenní dojížd'ku za maloobchodem a zjištování nákupního chování, byla použita kombinace dotazování v domácnostech a na ulicích (menší i větší obce). Spádovost za službami v zázemí Brna bylo, po vzoru minulých výzkumů, šetřeno pomocí dotazování lokálních lídrů - starostů obcí (příp. jejich výkonných zástupců). Ve vnitřním městě byl preferován rychlejší a neformálnější způsob dotazování na ulici. V Galerii Vaňkovka byli návštěvníci oslovováni v rámci kvótního výběru prímo v centru.

Co se týče Olomouce, šetření spádovosti za službami v zázemí Olomouce bylo provedeno také prostřednictvím zástupců obcí. Denní urbánní systém tohoto druhého modelového města, na kterém bylo šetření aplikováno, byl explicitně 
vymezen na základě dojížd'ky za prací. Zcela jiný př́stup než v př́padě Brna byl použit při zjišt́ování pohybů obyvatel za nákupy uvnitř města, jednalo se o metodu modelování prostorových interakcí - gravitační modely.

$\mathrm{K}$ šetření byly použity dotazníky, resp. jejich několik různých variant, jako u jiných, podobně zaměřených výzkumů (Maryáš, 1988; Kulke, 1992; Marjanen, 1995; Findlay et al., 2001; Szczyrba, 2002; Trembošová, 2010; Jackson et al., 2011 a další). Získaná data z dotazníků byla digitalizována a v řadě prípadů analyzována ve statistickém programu SPSS s využitím deskriptivních statistik a vícerozměrné regresní analýzy pro testování míry vlivu faktorů ovlivňujících variabilitu v denní dojižd'ce za nákupy a v nedenní dojížd'ce do obchodních center (šetření v Brně a jeho zázemí). Vybraná data byla následně prostorově analyzována a vizualizovaná v prostředí GIS (Geografických informačních systémů). Výsledky šetření a analýz jsou prezentovány také v podobě tabulek a kartografických výstupů.

$Z$ hlediska metodologie výzkumu jsme si vědomi omezení týkajících se interpretace zjištěných výsledků, které jsou zatiženy určitou mírou generalizace (např. kategorizace obcí na základě výpovědí od omezeného počtu respondentů zejména u malých obcí do 100 obyvatel - výzkum v zázemí Brna, taktéž omezený počet respondentů u populačně malých městských částí v případě výzkumu ve vnitřním Brně, schopnosti lokálních lídrů /starostů/ odhadnout „nákupní chování obyvatel obce apod.) a zároveň reflektují prostorová a dopravní specifika modelových území, tj. Brna a Olomouce a jejich zázemí. Výsledky šetření nelze sice považovat $z$ hlediska volby výběrového souboru za reprezentativní obraz celé české populace, přesto mají svoji vypovídací a prediktivní hodnotu a lze z nich vyvodit některé obecné závěry. Hodnotu výsledků je třeba posuzovat i z hlediska akutního nedostatku jiných „tvrdých dat" v této oblasti výzkumu.

Pro větší přehlednost a logiku čteného textu uvádíme jednotlivé konkrétní metodické přístupy v dílčích kapitolách, vždy před výsledky výzkumů. 


\section{Vývoj maloobchodu v České republice}

\section{1. Úvodem}

Maloobchod patří mezi ta hospodářská odvětví, která se vyznačují silným stupněm internacionalizace svých obchodních aktivit. Charakteristickým znakem současného maloobchodu je neustálé pronikání nadnárodních maloobchodních řetězců na zahraniční trhy a zásadní změny na těchto trzích. Podle Dickena (2003) pronikají maloobchodní řetězce na zahraniční trhy zprvu opatrně, posléze ovšem vykazují velmi silný sklon $\mathrm{k}$ lokalizaci na geograficky a kulturně př́buzné trhy.

K hlavním motivacím transnacionální expanze maloobchodních řetězců patří saturace a regulace domácích trhů a intenzifikace soutěživosti na nich, a také dojem, že na nových, rychle rostoucích trzích najdou nové obchodní přiležitosti. Používají k tomu různé cesty - budování vlastních prodejen, převzetí existujících firem, příp. fúze s domácími firmami, budování pozic formou licencování či franchisingu, zakládání joint-ventures a strategických aliancí. Samozřejmostí je budování vlastních logistických a distribučních center pro zásobování sítě svých prodejen. To samo představuje zajímavý geografický problém, umožňující sledovat složité a měnící se vztahy mezi výrobci a prodejci (Birkin et al., 2002). Vývoj v 90. letech 20. století byl ve světě ve znamení silné internacionalizace nově se rozvíjejících trhů v Latinské Americe, jihovýchodní Asii, střední a jižní Evropě. Šlo o internacionalizaci významného měřítka, která umožnila několika maloobchodním firmám rapidní ekonomický růst a posun v žebříčku největších maloobchodních firem světa na nejvyšší príčč (Wrigley, 2003).

Vlivem internacionalizace nastaly nejen významné organizační změny uvnitř odvětví, ale začala také transformace prostorové organizace maloobchodu. Začaly se rychle měnit územní parametry maloobchodní sítě, a to především vlivem vstupu velkoplošných prodejen do území. Nejvíce se změny dotkly měst, které se staly hlavním cílem expanze zahraničních maloobchodních řetězců na nové trhy, a to organizovaně v rámci sídelní hierarchie. Chápeme-li transformaci maloobchodu jako rozvoj maloobchodních sítí jednotlivých maloobchodních firem, pak města plní v tomto procesu úlohu uzlů (Wilk, 2005). Zejména vlivem rozvoje velkých nákupních center a hypermarketů a přesměrováním nákupních toků do těchto center došlo ke zcela zásadní změně uspořádání maloobchodních funkcí ve městech. Postupně začaly vznikat lokality komerční suburbanizace a vlivem decentralizačních tendencí, tolik typických pro velkoplošný maloobchod, nastává oslabení funkcí městského centra a přechod k polycentrickému uspořádání maloobchodních funkcí ve městě (Heineberg, 2006). Tento vývoj v postsocialistických 
městech byl dokumentován na mnoha př́kladech: v Polsku (Wilk, 2005; Namyślak, 2006), na Slovensku (Mitríková, 2008; Trembošová, 2009, 2010) i v České republice (Mulíček, 2004, 2007; Szczyrba, 2005; Szczyrba et al., 2001).

Rozvoj velkoplošné maloobchodní sítě znamenal dále rozsáhlé změny v nákupním chování (Spilková, 2003; Millan, Howard, 2007). Kromě těchto pro geografii již „tradičních" témat se objevují i témata nová, která souvisejí s vlivem velkoplošných maloobchodních prodejen na změny $v$ územní struktuře maloobchodní sítě. Jde např́iklad o vznik tzv. potravinových pouští, které představují území uvnitř většího města s omezeným výběrem prodejen potravin pro bydlící obyvatelstvo (Wrigley, 2002). Na př́kladu blízké Bratislavy se pokusili potravinové pouště vymezit Križan a Danielová (2008) či Križan et al. (2008).

\subsection{Výchozí podmínky transformace - situační analýza před rokem 1989}

Maloobchodní nabídka ke konci 80 . let minulého století byla regionálně a strukturně velmi diferencována. Poslední sčítání maloobchodu (v rámci Sčitání občanské vybavenosti sídel z roku 1987) tak ukázalo mimo jiné zcela neadekvátní sortimentní strukturu maloobchodu. Tehdy většinový podíl v maloobchodní síti tvořily prodejny potravin, zatímco ostatní sortiment byl silně potlačen (viz tabulka 4.1). Maloobchodní obrat realizovaný v síti čtyř vybraných základních sortimentních skupin prodejen dosahoval téměř $4 / 5$ maloobchodního obratu v zemi. Prodejny představovaly více než $86 \%$ stacionární maloobchodní sítě a podílely se zhruba $90 \%$ na její celkové prodejní ploše.

Tab. 4.1: Zastoupení vybraných sortimentně provozních jednotek v maloobchodní síti (k 31. 12. 1987)

\begin{tabular}{|l|c|c|c|c|}
\hline typ prodejny & $\begin{array}{c}\text { podíl v síti } \\
\mathbf{v} \%\end{array}$ & $\begin{array}{c}\text { prodejní } \\
\text { plocha } \\
\mathbf{v} \%\end{array}$ & $\begin{array}{c}\text { pracovníci } \\
\mathbf{v} \%\end{array}$ & $\begin{array}{c}\text { maloobchodní } \\
\text { obrat } \\
\mathbf{v} \%\end{array}$ \\
\hline OD a DNS & 1,8 & 12,7 & 12,6 & 11,4 \\
\hline prodejny potravin* & 57,8 & 47,8 & 48,4 & 41,2 \\
\hline prodejny odívání a obuvi & 12,1 & 14,3 & 12,7 & 12,1 \\
\hline prodejny průmyslového zboží & 14,4 & 14,6 & 12,8 & 15,0 \\
\hline vybrané typy celkem & 86,1 & 89,4 & 86,5 & 79,7 \\
\hline MO sít celkem & 100,0 & 100,0 & 100,0 & 100,0 \\
\hline
\end{tabular}

Zdroj: Szczyrba (2005)

Vysvětlivky: * Prodejny potravin - včetně prodejen smišeného zboží a prodejen tabáku OD - obchodní domy, DNS - družstevní nákupní střediska 
Organizačně a prostorově byl maloobchod v České republice (Československu) v období socialismu řízen na základě tehdejší politické direktivy, která jen omezeně akceptovala reálnou potřebu dostupnosti služeb v území. Socialistický model řízení odvětví obchodu se vyznačoval absolutním zákazem soukromého podnikání a determinací fungování obchodních firem. Typické pro toto období byly velké státní obchodní (Pramen, Prior) a družstevní podniky (Jednota), kterým politická direktiva určovala prostor pro podnikání. Od roku 1952 se tak družstva začala soustřed'ovat na podnikání na venkově, prodejnám státního obchodu byla zase určena města (Szczyrba, 2005). ${ }^{10}$ Zde započal proces prostorové nivelizace nabídky služeb obyvatelstvu, která byla největší mezi socialistickými zeměmi (Drtina, Krásný, 1989).

Odlišně se ve srovnání se západní Evropou vyvíjela i prostorová organizace maloobchodní sítě. Zatímco v zemích západní Evropy byla po krátkém poválečném období, charakterizovaném výstavbou maloobchodní sítě v tradičních centrálních oblastech, zaznamenána expanze na nové lokality (výstavba príměstských velkokapacitních obchodních středisek), maloobchod v českých zemích vykazoval menší prostorovou variabilitu. Lokalizace prodejen nerespektovala rozmístění koupěschopné poptávky, díky čemuž docházelo $k$ přetěžování maloobchodní sítě $v$ centrech většiny měst. Naproti tomu v periferních sídlištních souborech mnoha měst byly kapacity prodejních ploch nedostatečné. Velmi často s tímto obecně neutěšeným stavem kontrastovala nelogická výstavba prodejních kapacit v menších městech a venkovských sídlech (Krásný, 1990).

Řada odborných prací a studií průběžně poukazovala na nedostačující a nevyhovující stav tuzemské maloobchodní sítě, zejména na podprůměrné prodejní kapacity a s tím související přetižení prodejních ploch. Jak investice do rozvoje maloobchodní sítě, tak ukazatele plošného nebo obslužného standardu byly v Československu, ve srovnání se západními zeměmi, na poloviční úrovni (Drtina, Krásný, 1989). Maloobchodní sít před rokem 1989 tak byla v mnoha ohledech nedostatečná v kontextu reálné potřeby a nekompatibilní ve srovnání se zeměmi západní Evropy, např́klad i co se týká sortimentní struktury. Jak již bylo naznačeno, nedostatky $v$ maloobchodní vybavenosti byly vzhledem $k$ reálné poptávce více pozorovatelné u měst než na venkově.

$\mathrm{Na}$ obecně neutěšenou situaci poukazovaly nejen výsledky komplexní pasportizace "Sčítání občanské vybavenosti sídel“ z roku 1987, ale také závěry z provedené optimalizační studie z roku 1988, která modelově vycházela ze souboru 191 měst velikosti nad 10 tisíc obyvatel (Šimůnek et al., 1988). Analytické

10 Dlouho před tímto rozhodnutím byla česká a moravská spotřební družstva typickým městským obchodním prvkem. 
a optimalizační propočty jednoznačně prokázaly prvořadou potřebu kapacitního i kvalitativního rozvoje maloobchodní sítě hlavního města Prahy, a to ve všech sortimentech. Podobně na tom byly i oba moravské kraje, zejména pak jádro brněnské aglomerace a nejvýznamnější střediska osídlení ostravské aglomerace.

$S$ podobnými závěry o úrovni vybavenosti našich měst přišel rovněž Maryáš (1990), který dokumentoval nedostatky v kapacitních ukazatelích za nepotravinářské zboží při hodnocení na úrovni základních obslužných regionů a jejich středisek. Relativně dobře byla v Čechách hodnocena obslužná střediska severočeské regionální aglomerace, severozápadních Čech a jádra východočeské sídelní regionální aglomerace. Naproti tomu nedostatečně vybavenými byly shledány základní obslužné regiony zaujímající rozsáhlou oblast Plzeňska a prakticky celé střední Čechy s výběžky na Liberecko a Děčínsko a také do jižní části východních Čech. Na Moravě šlo o Brno, které mělo velký deficit prodejních ploch nepotravinářského zboží (největší v tehdejším Československu), dále města jihovýchodní Moravy a obslužné regiony v širokém zázemí ostravské aglomerace.

Obr. 4.1: Regionální struktura plošného standardu v roce 1987

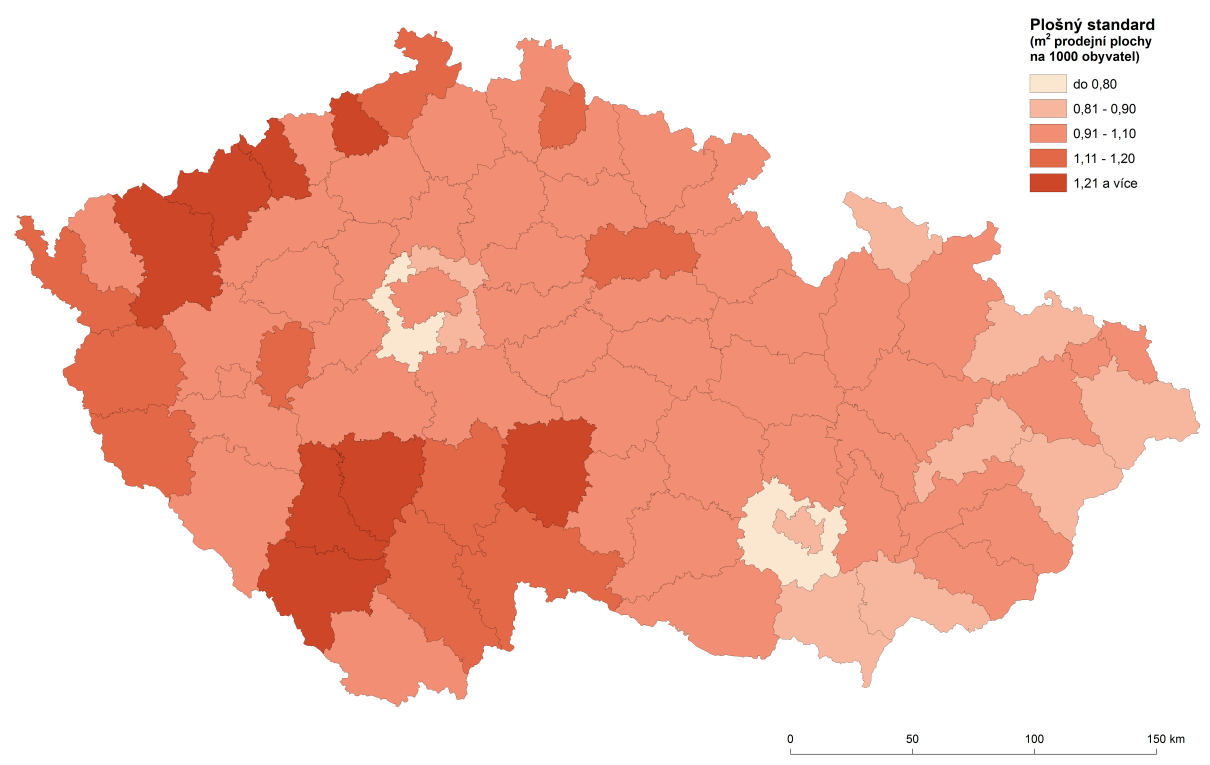

Zdroj: Sčitání občanské vybavenosti sídel, 1987. 
Obr. 4.2: Obchodní dům Koruna v historickém centru města Olomouc

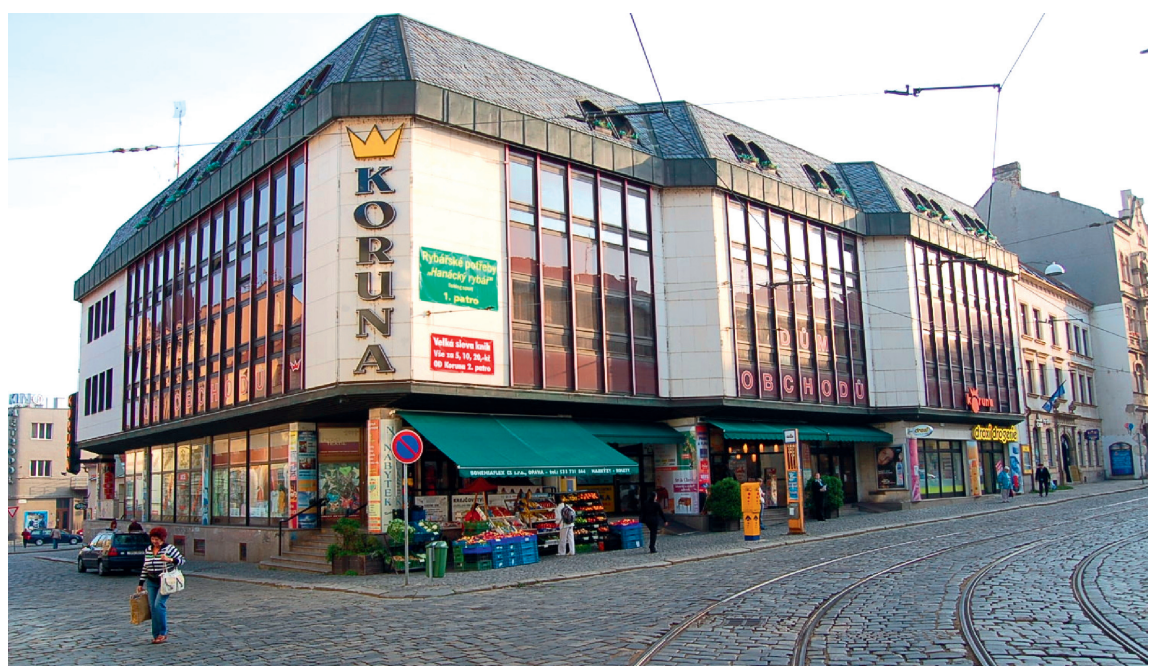

Foto: Zdeněk Szczyrba

Pozn.: Obchodní domy patřily v obdobi pred rokem 1989 k jediným plnosortimentním velkoprodejnám v tehdejším Československu, navíc často lokalizovaným do center měst, zatímco v jiných městských lokalitách byla nabídka maloobchodu nedostačující. Výsledkem byla velmi frekventovaná docházka obyvatel za nákupy do městských center.

\section{Obr. 4.3: Nákupní středisko v Potštejně (okres Ústí nad Orlicí)}

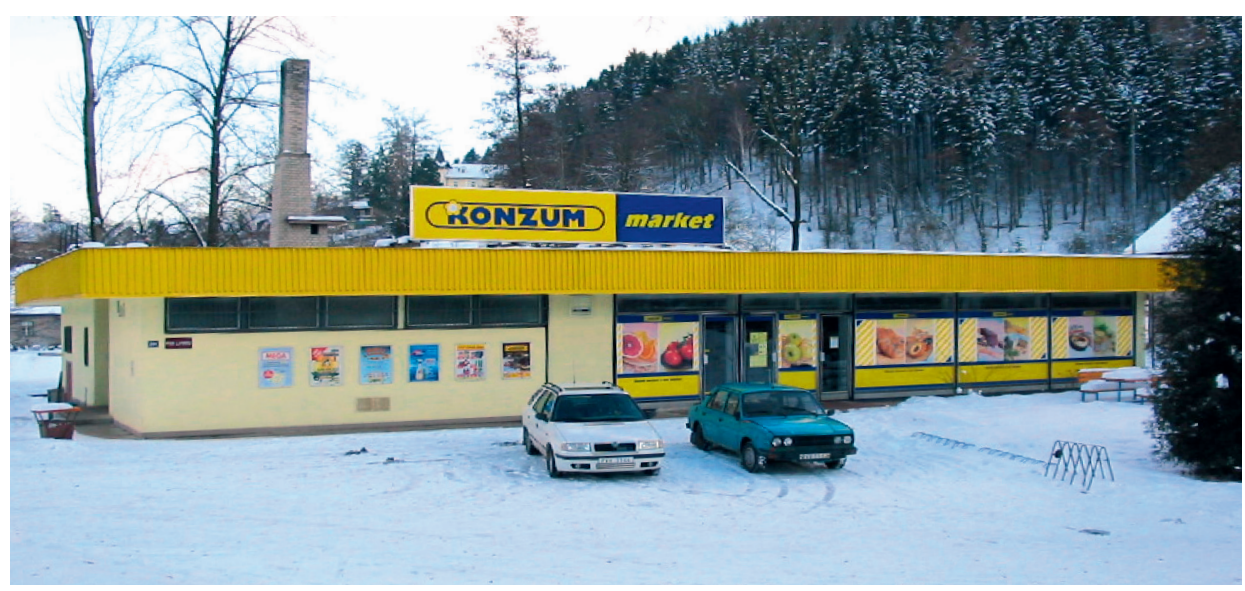

Pozn.: Př́kladová provozní jednotka občanské vybavenosti na českém venkově v 70. a 80. letech 20. století. Výstavba velkorysých maloobchodních kapacit na venkově byla v souladu s celostátní koncepcí strediskové soustavy osídlení a tzv. plošného vyrovnávání rozdílů mezi městem a venkovem. 


\subsection{Etapy rozvoje nové geografické struktury}

Vývoj v odvětví maloobchodu po roce 1989 byl v nových společensko-ekonomických podmínkách velmi dynamický a během více než dvaceti let procházel několika etapami. Z hlediska změn základních rysů geografické struktury českého maloobchodu Ize proces transformace odvětví rozdělit celkem do tří etap:

- Etapa atomizace (1990-1995),

- Etapa internacionalizace (1996-2005),

- Etapa konsolidace (2006-současnost).

\section{Etapa atomizace}

Transformace maloobchodu na počátku 90. let 20. století byla založena na liberalizaci a privatizaci české ekonomiky, jejíž hlavní principy byly zformulovány ještě v období Československa. Privatizační proces byl z velké části založen na modelu tzv. malé privatizace, která umožnila privatizovat do soukromých rukou tisíce prodejen dřive státních podniků (Pramen). Pouze pro část velkých státních podniků (např. Prior) existoval jiný model privatizace (prodej na základě privatizačního projektu nebo formou kupónové privatizace). Výsledkem byla rozsáhlá atomizace maloobchodu a vznik širokého spektra podnikatelských struktur v odvětví, které velmi aktivně začaly vyplňovat deficity maloobchodní sítě. Vedle toho vznikaly tisíce nových prodejen a obchodních podniků vlivem liberalizace české ekonomiky, to vše převážně na bázi domácího kapitálu a formou rodinných podniků.

Velmi názorně počáteční etapu transformace českého maloobchodu ilustrují výsledky Retail Censu 99. Tento census ukázal, že počet maloobchodních prodejen provozovaných na území České republiky se v roce 1998 oproti roku 1989 zvýšil více než dvojnásobně, a to z 41 na téměř 96 tisíc. Nejvýraznější kvantitativní změna během sledovaného transformačního období proběhla u nepotravinářského typu prodejen (více než čtyřnásobný růst). $V$ maloobchodní síti zaujímaly největší podíl malé prodejny do $40 \mathrm{~m}^{2}$ (60\%). Jak dále ukázala data z maloobchodního censu, klesla efektivita provozování prodejen ve venkovském prostoru (výzkumy maloobchodu ve venkovském prostoru v tomto období viz např. Majerová et al., 2003), a to na úkor měst, která naopak začala posilovat své pozice $v$ maloobchodním systému.

Zatímco prodejní plocha v roce 1989 činila přes 3,5 mil. $\mathrm{m}^{2}$, v roce 1998 to již bylo více než 7,1 mil. $\mathrm{m}^{2}$ a prepočteno na počet obyvatel vzrostl plošný standard z 331 na téměř $697 \mathrm{~m}^{2}$. Podíváme-li se do regionů, zjistíme relativně vysokou variabilitu úrovně plošného standardu, která v roce 1998 oscilovala mezi $519-828 \mathrm{~m}^{2}$ prodejních ploch v přepočtu na 1000 obyvatel kraje. Většina krajů ČR vykazovala v daném roce pouze průměrnou úroveň vybavenosti ( $\pm 10 \%$ průměru), ve třech regionech byla zjištěna nadprůměrná (Středočeský, Jihočeský 
a Plzeňský kraj), ve dvou regionech dokonce výrazně podprůměrná úroveň plošného standardu (Zlínský a Moravskoslezský kraj). Tyto rozdíly byly determinovány především počínajícím vývojem velkoplošné maloobchodní sítě, která byla v roce 1998 teprve ve své iniciační etapě (Szczyrba, 2004).

Obr. 4.4: Regionální struktura plošného standardu v roce 1998

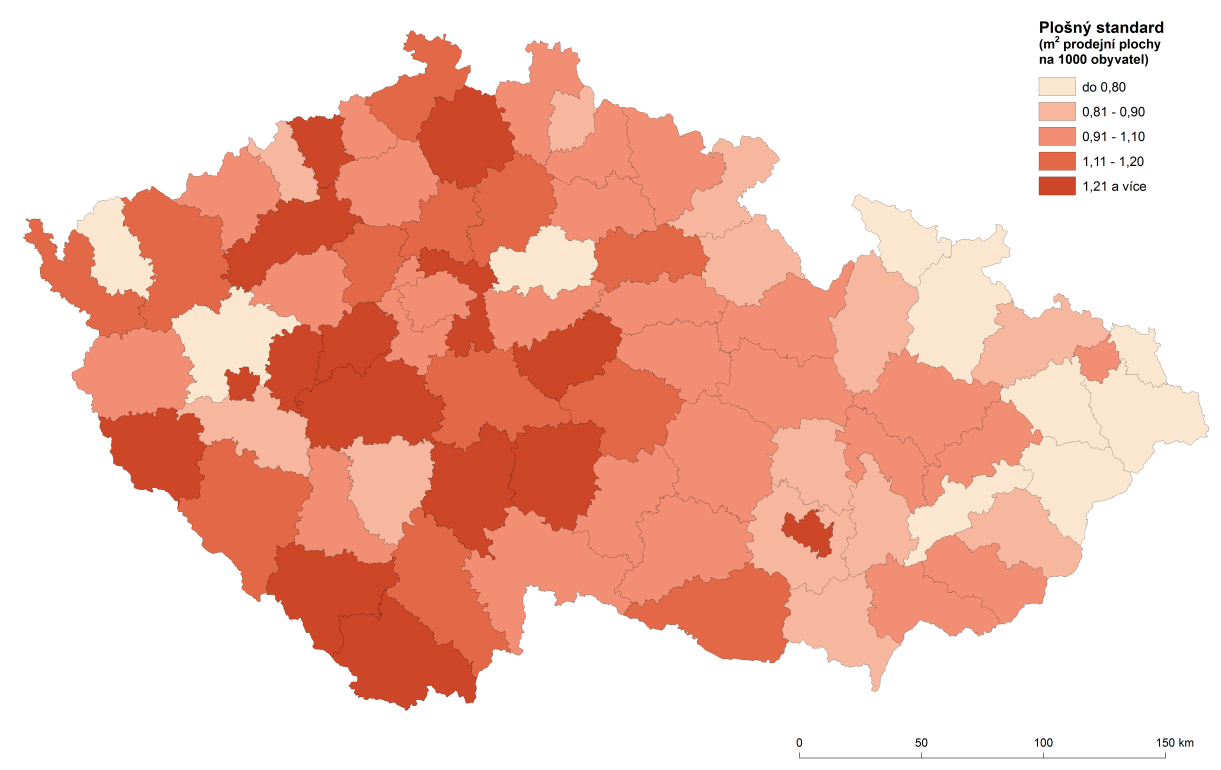

Zdroj: Retail Census 99, Čsú 1999.

\section{Etapa internacionalizace}

Zvýšená expanze zahraničních maloobchodních řetězců na český trh započala až ve druhé polovině 90 . let 20 . století. Do té doby se na českém trhu prosazovaly jen některé zahraniční firmy (např. belgický Delhaize, nizozemský Ahold či německá Billa). Pưsobil zde i americký řetězec K-mart, jehož přítomnost byla výsledkem privatizace šesti obchodních domů Prior (v Praze, Brně, Liberci, Plzni, Pardubicích a Hradci Králové). Aktivity tohoto řetězce na českém trhu skončily již $v$ roce 1996, kdy K-mart prodal své obchodní domy britskému řetězci Tesco. Tato akvizice byla součástí širší strategie internacionálních operací firmy nejen v regionu střední Evropy (Wrigley, 2003). Teprve v druhé polovině 90. let 20. století začala masivnější internacionalizace českého maloobchodu. Jejich pozice na trhu byla od začátku dominantní, bez větší konkurence ze strany tuzemských firem. Jak uvádí Starzyczná (2010), české firmy trpěly řadou kapitálových a profesních 
nedostatků (nedostatek kapitálu, nižší profesionalita řízení nebo absence zkušeností), které jim bránily rozvíjet podnikání v segmentu velkoplošného maloobchodu, a proto byly nuceny ustoupit z trhu.

Postupně se český maloobchod vyvinul ve vysoce konkurenční odvětví a ne všechny maloobchodní řetězce $v$ něm později zůstaly. $V$ roce 2006 opustil český trh francouzský řetězec Carrefour, své hypermarkety prodal konkurenčními britskému řetězci Tesco. Jiným príkladem byl prodej sítě supermarketů Julius Meinl nizozemskému koncernu Ahold (2006) nebo prodej sítě 130 prodejen drogerie Droxi skupiny Julius Meinl německému řetězci Schlecker (2007). Vlivem bankrotu mateřské společnosti v Německu odešel posledně jmenovaný řetězec $v$ roce 2012 zcela z tuzemského trhu. ${ }^{11}$

Charakteristickým rysem této etapy transformace maloobchodu v České republice je dále rostoucí koncentrace odvětví, kterou charakterizuje růst podílu prodejů realizovaných největšími firmami. Zatímco v 90 . letech 20 . století bylo možno spatřit mezi největšími obchodními společnostmi také některé domácí firmy (Interkontakt Group nebo Pronto Plus), dlouhé roky již pozorujeme zcela jinou situaci. Přední pozice $v$ žebříčku TOP 10 patří výhradně zahraničním subjektům. Ve srovnání s výsledky v letech předcházejících ztrácejí tuzemské firmy prokazatelně své tržní podíly ve prospěch mezinárodních obchodních společností, a to i díky tomu, že tyto řetězce převzaly do svých aktivit funkci velkoobchodu, čímž také získaly výhodnou pozici vůči dodavatelům zboží. Největší koncentraci pozorujeme v odvětví širokosortimentního prodeje, kde se podíl deseti největších prodejců blíží hranici 70 \% (Moderní obchod, 5/2010).

\section{Etapa konsolidace}

Podíváme-li se na tempa meziročního růstu největších retailerů za poslední roky, zdaleka již nedosahuji úrovně počáteční fáze internacionalizace, kdy tržby meziročně rostly $v$ řádu desítek procent. $V$ posledních letech dochází ke konsolidaci maloobchodního trhu, který charakterizuje menší dynamika růstu největších obchodních firem a jejich současné posilování tržních pozic. Jak již bylo uvedeno, vliv na to měly i odchody některých velkých maloobchodních řetězců z České republiky počínaje rokem 2006.

Český maloobchodní trh je odborníky řazen mezi vysoce konkurenční a nasycené trhy, a tak udržet se na něm je i pro velké mezinárodní společnosti značně obtížné. Součástí konsolidační etapy tak patrně v blízké budoucnosti budou další prodejen rozšíril sít na více než 700 prodejen. Bankrot Schleckeru v Německu měl za následek zrušení celé sítě, což reprezentovalo kolem dvou tisíc prodejen a více než 10 tisíc zaměstnanců (Hospodářské noviny, 21. 6. 2012). 
odchody velkých firem z trhu. Získáním jejich tržních pozic ještě více posílí koncentrační tendence $v$ odvětví a dojde $k$ posílení některých jiných velkých řetězců.

\subsection{Utváření sítové struktury v českém maloobchodě}

Transformace sittové struktury českého maloobchodu započala rozvojem jednotlivých velkoformátových prodejních konceptů, které reprezentují inovaci v odvětví i území (Pražská, Jindra, 1997). Odhlédneme-li od provozně-organizační struktury maloobchodu z dob před rokem 1990, kterou reprezentovaly regionální sítě vymezené na administrativním principu (Prameny, Jednoty), pak první náznaky utváření nových sítových struktur uvnitř českého maloobchodu na tržním principu byly k vidění již v první vývojové etapě transformace - atomizace (Starzyczná, Steiner, 2000; Szczyrba, 2005).

Na počátku 90. let 20. století vstoupily na český maloobchodní trh (v omezeném rozsahu) první zahraniční společnosti (např. Ahold, Delvita), které začaly budovat svou maloobchodní sít cestou akvizicí stávajících prodejen, technicky i prostorově vyhovujících firemním požadavkům. Skutečný rozvoj nových velkoformátových prodejních konceptů nastal až v druhé vývojové etapě (internacionalizace), kdy do ČR přicházely postupně největší potravinářské i nepotravinářské nadnárodní maloobchodní koncerny (Szczyrba, 2005; Szczyrba et al., 2007).

$V$ souvislosti s příchodem zahraničních maloobchodních řetězců na český trh započala etapa rozvoje maloobchodní sítě formou budování velkoplošných maloobchodních jednotek. Vytvořily se charakteristické sítě velkoplošných provozních jednotek, které postupně začaly dominovat trhu. Podobně se formovaly sítové struktury maloobchodu v dalších zemích regionu, na Slovensku (Mitríková, 2008) či v Polsku (Wilk, 2005).

Charakteristickým rysem vývoje na českém trhu byla časová posloupnost procesu rozvoje jednotlivých velkoformátových prodejních konceptů. Šlo o vývoj, během něhož byly českou spotřebitelskou populací postupně přijímány prakticky všechny moderní velkoplošné prodejny. Rozvoj maloobchodní sítě v České republice byl založen na budování moderní sítě s širokým spektrem velkoprodejen a Ize ho rozložit do jednotlivých subfází (Szczyrba, 2005; Szczyrba et al., 2007):

1. subfáze, dynamický rozvoj v síti supermarketů, $1995 \rightarrow$,

2. subfáze, dynamický rozvoj v síti diskontů, $1997 \rightarrow$,

3. subfáze, dynamický rozvoj v síti hypermarketů, $1998 \rightarrow$,

4. subfáze, dynamický rozvoj v síti nákupních center, $2000 \rightarrow$.

Sítování v linii hypermarketů představuje jeden z nejviditelnějších rysů transformace českého maloobchodu. Hypermarkety se staly rozhodujícím fenoménem dynamiky změn $v$ českém maloobchodě a vzhledem ke své regionální dimenzi 
v územní struktuře a maloobchodní gravitaci představují páteř maloobchodní sítě v ČR. Jak vyplývá z nejnovějších údajů společnosti Incoma GfK (Hypermarket, 2011), preference tohoto formátu u českých spotřebitelů dosahuje již zhruba $45 \%$ u pravidelně nakupujících domácností (potraviny a drogerie). Ve stručném srovnání - supermarkety zastavily pokles obliby a dostaly se na $18 \%$ podíl, diskonty v posledních letech ztrácejí a jsou už pouze těsně nad $1 / 5$; zbylé preference vyčíslené zhruba $17 \%$ si drží menší prodejny typu COOP či Hruška. Na počátku roku 2012 bylo na území České republiky asi 280 hypermarketů, s předpokladem dosažení hranice 300 do konce roku, což by z hlediska kupní síly mohlo znamenat dostatečné pokrytí. S počtem 26 hypermarketů na 1 milion obyvatel se ČR řadí na 4. přičku v pořadí Evropských zemí a s aktuálním tempem růstu Ize očekávat v nejbližších letech posun i na pozici nejvyšší.

Šetření Hypermarket 2011 také poukazuje na skutečnost, že ve vzdálenosti do $20 \mathrm{~km}$ od některého z hypermarketů žije již 88 \% české populace. Pochopitelně existují v dostupnosti hypermarketů poměrně velké regionální rozdíly, sever a východ republiky je vzhledem $\mathrm{k}$ sídelní struktuře pokryt daleko silněji než západ a jih. Je zřejmé, že tzv. „bílých míst“ už přiliš mnoho není (viz obrázek 4.5) a i ta budou postupně ubývat. Hypermarkety začínají pronikat i do malých měst velikosti 10-20 tis. obyvatel (Sušice, Česká Třebová, Rychnov nad Kněžnou a další). Výjimkou jsou zatím řídce osídlená území, kde nelze najít pro umístění hypermarketu vhodnou lokalitu.

Největší relativní koncentrace ke konci desetiletí byla v Karlovarském, Ústeckém a Moravskoslezském kraji (20-30 tis. bydlících na 1 hypermarket), nejmenší v Praze (zhruba 50 tis.), kde je však velké množství jiných typů maloobchodních prodejen. $V$ absolutních číslech dominují silně urbanizované kraje Moravskoslezský a Ústecký, ale i region středních Čech. Průměrná velikost nově otevíraného hypermarketu se dostala z původních řádových 10 tis. $\mathrm{m}^{2}$ hrubé pronajímatelné plochy na současné 3-4 tis. $\mathrm{m}^{2}$.

Hypermarkety začaly být v další fázi svého vývoje (4. subfáze) integrovány do funkční struktury nákupních center. Systém fungování nákupního centra je $z$ velké části založen na př́tomnosti hypermarketu (nejčastěji velkého hypermarketu, tj. více než 5 tisíc $\mathrm{m}^{2}$ prodejní plochy), který plní funkci tzv. kotvy nebo magnetu (primární cíl pro nakupující). $V$ tomto směru je značná část z realizovaných hypermarketů součástí některého z nákupních center.

Velká nákupní centra jsou lokalizována hlavně v Praze a dalších velkých regionálních centrech (Brno, Ostrava, Plzeň, Liberec apod.). Menší nákupní centra se v posledních letech velmi dobře uchytila ve městech střední velikosti (20-50 tis. obyvatel). Obchodní komplexy typu malých retail parků se velmi rychle začínají rozvíjet ve městech kolem 30 tisíc obyvatel, případně i menších (Břeclav, Vyškov, Česká Třebová a další). Jde o nový trend se začátky v letech 2007-2008. O nákupních centrech podrobněji v další kapitole. 
Obr. 4.5: Území vymezená $20 \mathrm{~km}$ vzdáleností od některého z hypermarketů (2010)

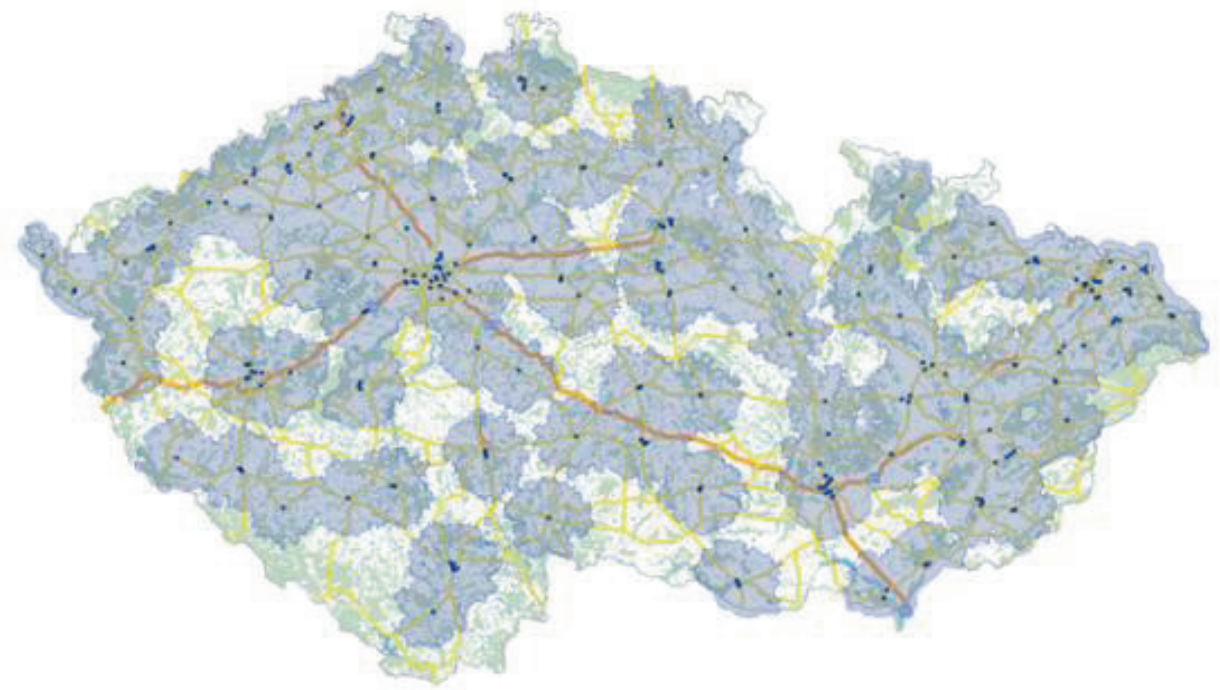

Zdroj: Hypermarket 2011 (Incoma GfK, www. incoma.cz).

Dynamicky se dále rozvíjejí diskontní prodejny, které jsou po hypermarketech hned druhým nejoblíbenějším typem velkoprodejen ( 25 \% pravidelných nákupů českých domácností). Ve své iniciační fázi šlo o rozvoj prodejní sítě německých obchodních řetězců Plus a Penny Market. Razance, s jakou tyto řetězce vstoupily na trh v roce 1997, vyústila v pojmenování této iniciace jako "rok diskontů“."12 Počínaje rokem 2003 započala rychlá expanze dalšího německého diskontního řetězce Lidl. Společně tyto tři řetězce reprezentují více než $4 / 5$ diskontní sítě v ČR.

\subsection{Difúze sítí v českém maloobchodě}

Charakteristickým rysem vývoje ve druhé polovině 90 . let 20. století byla časová posloupnost procesu zavádění jednotlivých prodejních konceptů na trh. Tuto fázi transformace Ize také interpretovat jako interferenci jednotlivých obchodních sítí, kdy se v čase dynamizuje rozvoj určitého typu maloobchodní jednotky (obchodního řetězce), čímž dochází k postupné provozní a prostorové koncentraci 
maloobchodní sítě. Jak ukazuje dosavadní vývoj utváření sítové struktury tuzemské maloobchodní sítě, vykazuje lokalizace velkoplošných prodejen v území difúzní charakter. Inovace v podobě nového prodejního konceptu, at' už se jedná o hypermarket, supermarket, diskont či nákupní centrum, je poměrně rychle adaptována jeho uživateli (spotřebiteli), šírí se rychle prostorem - difunduje tedy bez výraznějších bariér (Szczyrba, 2005; Szczyrba, Toušek, 2006; Szczyrba et al., 2007).

V kontextu změn uvnitř maloobchodní sítě a vzniku její sítové struktury jde o vývoj, který je ovlivňován především faktorem trhu a polohy, tj. dosaženým stupněm urbanizace v kombinaci s ukazatelem kupní síly. Před zhruba 3-4 lety dosažená fáze vrcholné expanze, resp. současná fáze vyplňování, řizená zahraničními obchodními řetězci, se dostává do stadia prostorové koncentrace a maloobchodní sít se zahuštuje. Tato fáze je typická sílícím posunem ve vertikálním směru od větších sídel $k$ menším, resp. posunem $z$ centrálních lokalit v rámci většího obsluhovaného území $\mathrm{k}$ menším střediskưm obsluhujících území menších měřitek (expanzivní hierarchická difúze). Jak již bylo výše uvedeno, v praxi se tak velkoformátové prodejní koncepty typu hypermarketů posouvají do středisek s kritickou populační velikostí střediska a zázemí již pod 30 tis. obyvatel, diskontní řetězce prakticky do všech obchodně významných středisek pro odbyt jejich zboží, tj. na nejnižší hierarchickou úroveň středisek obslužnosti. Pouze nákupní centra se zatím mimo největší střediska nerozšiřují (Szczyrba et al., 2007), další nový prodejní koncept, jímž jsou retail parky, již ovšem ano.

$\checkmark$ posledních letech je pro fázi vyplňování maloobchodní sítě typické zmenšování prodejen. Příčina je především ekonomická, některé obchody, zejména $\checkmark$ menších městech, byly prodělečné, a tedy zavřeny, resp. byly v pronájmu v prostorách bývalých samoobsluh ještě z doby socialismu a vypršel jim pronájem. Většina řetězců však v menších i větších městech zůstává, ale snižuje svoji prodejní plochu. $V$ Praze a dalších velkých městech roste obliba tzv. expresních prodejen, tedy malých konceptů kolem $100 \mathrm{~m}^{2}$ prodejní plochy, které vznikají $v$ místech, kde často nelze zaparkovat auto (centra měst) a zákazník je nucen přijít pěšky. Tyto prodejny nabízejí omezenější sortiment než větší koncepty, jedná se o potraviny a další základní potřeby. Jejich otevírací doba je příznivá i pro zákazníky s pozdějším koncem pracovní doby.

Použití konceptu difúze inovací je nejen názorné, ale dovoluje nám lépe rozumět prostorovým aspektům rozvoje "české" velkoplošné maloobchodní sítě. Maloobchodní řetězce pracují s vlastní expanzní politikou pro jednotlivé spotřební trhy, a i když se tyto modely mohou zdát jako podobné, při detailnějším pohledu tomu tak není. $V$ následující části se zaměříme na obecné modely chování maloobchodních řetězců na českém trhu, na způsoby, jak maloobchodní retězce pronikaly na tento trh. Princip využití konceptu difúzí inovací (Hägerstrand, 1953, 1968; Rogers, 1962, 2003; Łoboda, 1974; Hagget, 1975; Siwek, 1979 
a další) jako vědeckého př́stupu hodnoticího proces společenské adopce inovací, které přicházely na český maloobchodní trh po roce 1989, je založen na sledování roku otevření konkrétní prodejny v daném sídle (změny v čase a prostoru). Data pro tento na první pohled snadný úkol (nikoliv však jejich reálný sběr) byla čerpána z oficiálních databází šetřených řetězců, různých internetových zdrojů a informačních materiálů, popř. byla dopIněna z aktualizované databáze Retail Czech (společná databáze kateder geografie UP v Olomouci a regionální ekonomie a správy MU v Brně).

$\checkmark$ regionálně-geografickém kontextu Ize na území České republiky identifikovat tyto tři základní typy difúze:

a) expanzivní hierarchická difúze se šírí v závislosti na velikosti obsluhovaného území, resp. koncentraci obyvatelstva; velikost prodejny koreluje s významem a velikostí sídla v sídelně obslužném systému a lokalizace velkoprodejen v území probíhá na principu komplementarity. ${ }^{13}$ Reprezentanty modelu je většina maloobchodních řetězců v zemi a budování sítí je postupné a trvá několik let. Pro ilustraci difúze byl zvolen maloobchodní řetězec Tesco, jenž v současné době, kromě výběrového doplňování sítě hypermarketů a supermarketů (fáze vyplňování), posouvá svoji obchodní strategii k menším formátům typu Express (Praha a okolí, další velká města: Ostrava, Havířov, Karviná nebo České Budějovice). Na konci roku 2010 Tesco koupilo od investiční společnosti Penta maloobchodní sít Žabka (ponechalo prodejnám původní název), kterou reprezentují potravinářské prodejny velikosti do $100 \mathrm{~m}^{2} \mathrm{~s}$ jasně vyprofilovanou lokací do městských částí a k pěší docházce. Následným rozvojem sítě došlo k dalšímu vyplňování prostoru. $\checkmark$ tomto si Tesco počíná na domácím trhu dominantně. 
Obr. 4.6: Expanzivní hierarchické difúze sítě hypermarketů TESCO v České republice
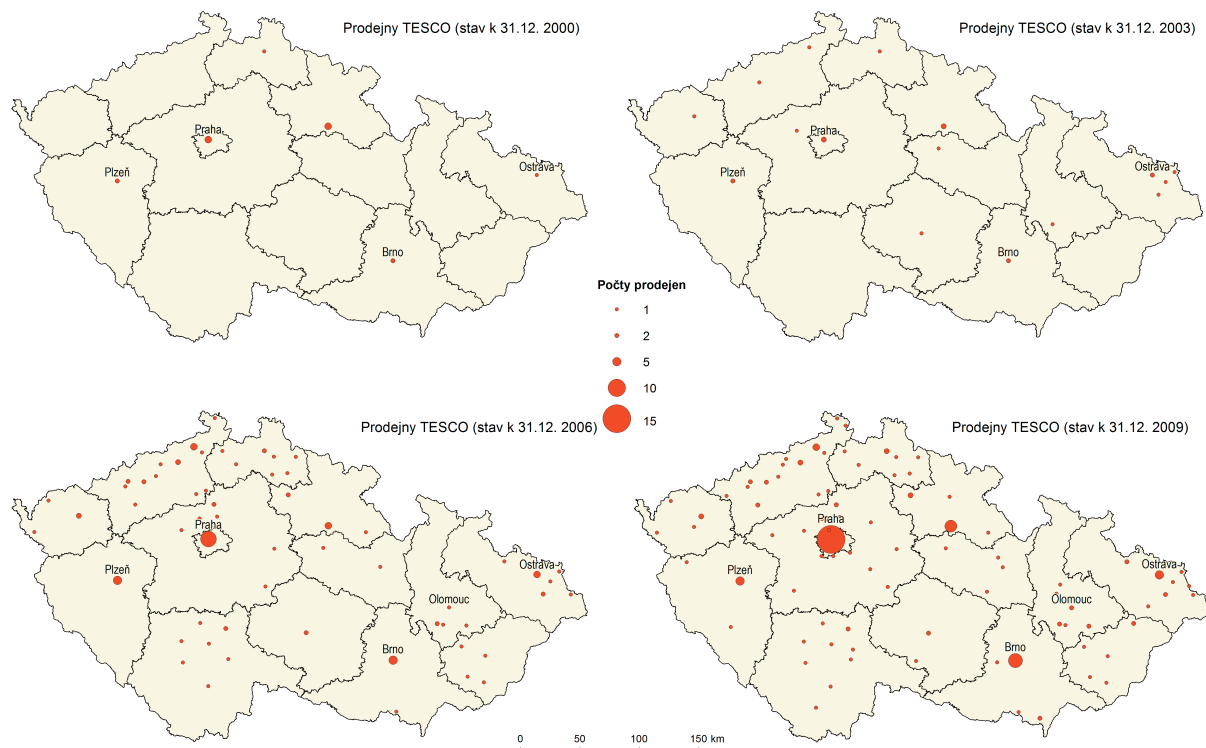

5

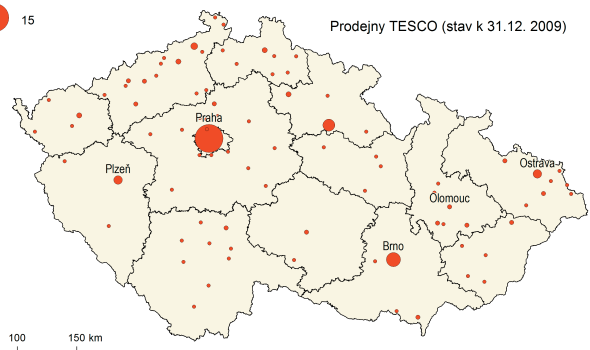

Zdroj: Interní data maloobchodních řetězců, vlastní zpracování.

\section{Rámeček 4.1: Maloobchodní řetězec Tesco}

Prvním typickým představitelem časoprostorové difúze je retailingový gigant, britský koncern Tesco, jenž je dlouhodobě v první pětce globálních maloobchodních lídrů podle výše obratu. Jeho historie v ČR sahá do roku 1996, kdy od amerického řetězce $K$-mart koupil šest obchodních domů. O dva roky později zahájilo Tesco svoji prostorovou expanzi na bázi velkoformátových hypermarketů, strategicky lokalizovaných ve velkých městech (podobně jako prvních šest odkoupených obchodních domů). Postupem času přesouvalo Tesco svoje aktivity i do menších měst a své portfolio rozšířilo na malé hypermarkety, supermarkety a další koncepty. Obchodní strategií je vysoká kvalita prodeje a velké množství prodávaných položek. V roce 2012 provozovalo Tesco na území ČR zhruba 230 obchodů všech typů, navíc také přibližně 140 prodejen Žabka.

b) expanzivní kontaktní difúze s vinovým charakterem je typická pro expanzi maloobchodních diskontních řetězců Penny Market a Plus. inovační vlny se šírily od západu na východ až ke hranici se Slovenskem bez ohledu na velikost sídla a koncentraci obyvatelstva (vyjma Prahy). Jak uvádějí Szczyrba et al. (2007), v průběhu postupující viny docházelo k vyplňování prostoru na již „obsazeném“ území. 
Je otázkou, zda fúze diskontů Penny a Plus znamenala pro nástupníka, jímž se Penny Market stal, prakticky fázi nasycení. Zatím se to tak nejeví, a to i přesto, že společnost REWE musela část svých prodejen odprodat. Sít Penny se zejména v menších městech kolem 5-10 tis. obyvatel často pouští do konkurenčního boje s podobně zaměřeným diskontním konceptem řetězce Lidl a sít vyplňuje i v městech velkých. I když sit́ Discount Plus nepůsobí již několik let na trhu, je tato ukázka šiření vlny důležitým poznáním modelu chování zahraničních maloobchodních řetězců v České republice.

Obr. 4.7: Expanzivní kontaktní (vlnové) difúze sítě diskontních prodejen Penny Market $v$ České republice

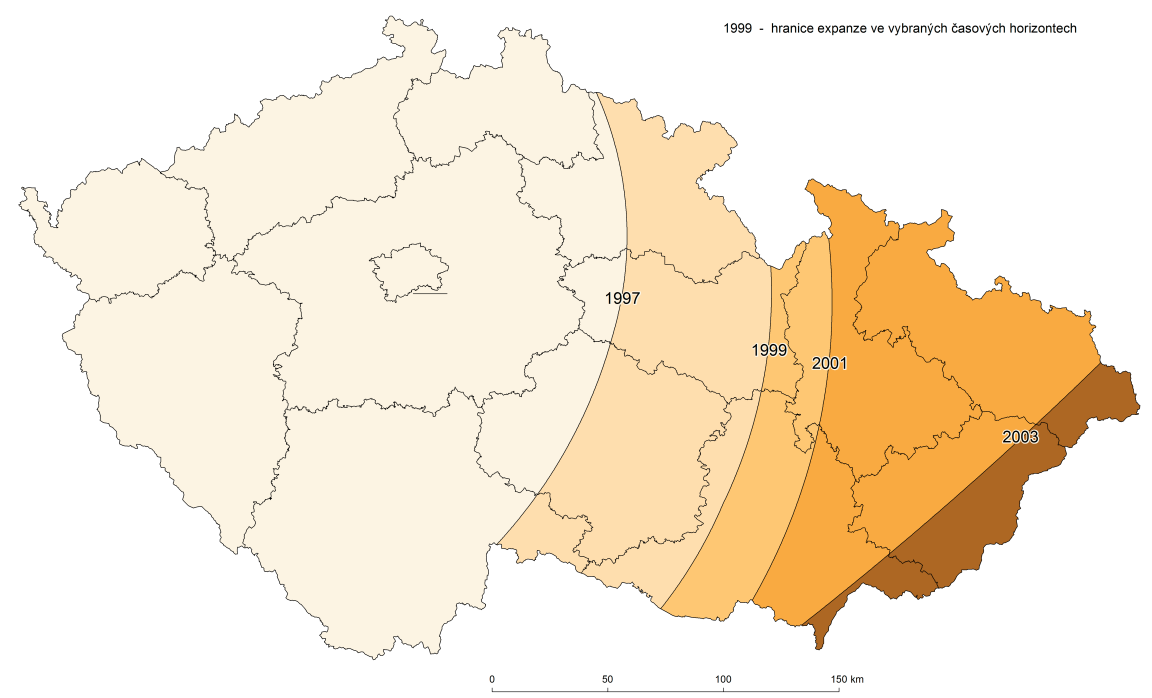

Zdroj: Interní data maloobchodních řetězců, vlastní zpracování.

\section{Rámeček 4.2: Maloobchodní řetězce Penny Market a Plus Discount}

Diskontní řetězec Penny Market je původem německá firma, která je dnes dceřinou společností mezinárodního obchodního řetězce REWE GROUP, jež patří ve světě v oboru mezi největší obchodní společnosti. Na českém trhu působí od roku 1997. Podobně jako konkurenční Lidl se orientuje na jednotky s nižší kvalitou prodeje, menším množstvím prodávaných položek (kolem 1,5 tisíce, což je více, než má Lidl) a nízkými cenami. Koupí dalšího konkurenčního řetězce Discount Plus (na českém trhu od roku 1992) v roce 2008 zdvojnásobil Penny Market svou sit́ na současných zhruba 330 prodejen po celé ČR a stal se podle obratu českou diskontní jedničkou. 
c) expanzivní kontaktní difúze probíhají formou tzv. „plošné expanze“. Jedná se o okamžité celoplošné pokrytí území státu charakteristické zprovozněním několika (desítkami) prodejen v jeden den, kterým firma zahajuje územní expanzi na trhu. Tento prístup v České republice uplatnil zatím jediný zahraniční obchodní řetězec - Lidl. V polovině roku 2003 otevřel v jednom časovém okamžiku 14 diskontů a po určitém období doplnil sít o další podobný počet. Difúze prochází územím bez výraznějších hierarchických střediskových vazeb, růst počtu jednotek je po vstupu poměrně pravidelný, bez výraznějších vln či skokủ. Lidl se nachází ve vrcholné fázi rozrůstání, další expanze je očekávána zejména v menších městech s počtem obyvatel kolem 5 tisíc.

Obr. 4.8: Expanzivní kontaktní difúze (plošná expanze) sítě diskontních prodejen Lidl $v$ České republice
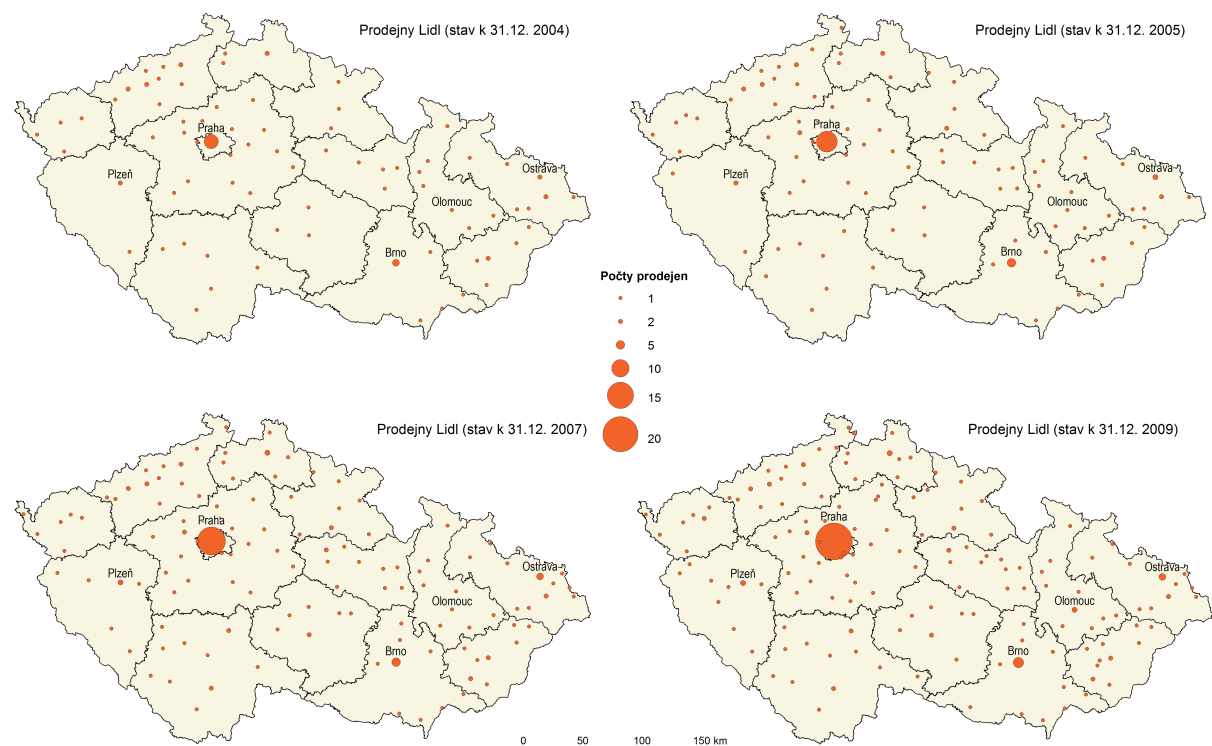

10
15
20
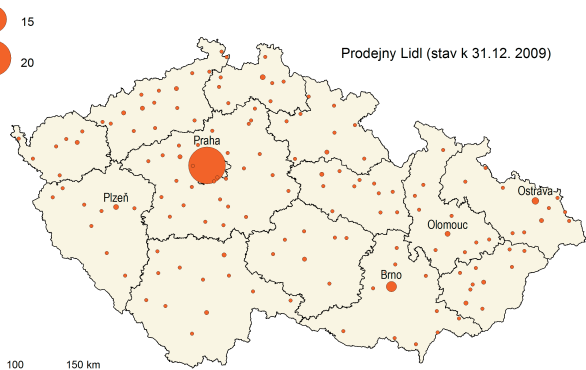

Zdroj: Interní data maloobchodních řetězců, vlastní zpracování. 


\section{Rámeček 4.3: Maloobchodní řetězec Lidl}

Lidl patří spolu s maloobchodním řetězcem Kaufland do německé skupiny Lidl \& Schwarz a jedná se o největší sít diskontních prodejen potravin v Evropě. Podle firemní strategie se zaměřuje na jednotky s nižší kvalitou prodeje, menším množstvím prodávaných položek (méně než tisíc) a nízkými cenami. Provozovny lokalizuje především v malých městech a na venkově, kde mají lidé nižší průměrné příjmy, a mají proto větší zájem o levnější výrobky. Vychází z nízké prodejní marže, rychloobrátkovosti, a tedy i čerstvosti zboží. Kulturou prodeje a dalšími atributy je ještě výraznějším diskontem než v Českém republice tržbami nejsilnější Penny Market. Rozlohy

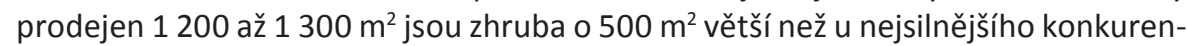
ta Penny. V současnosti provozuje Lidl téměř 300 prodejen a jeho tržní potenciál není ještě nasycen.

\subsection{Plánování v maloobchodě}

Hovoříme-li o plánování maloobchodu, pak máme na mysli především prostorové plánování maloobchodní sítě tak, aby nedocházelo $\mathrm{k}$ nežádoucím změnám uvnitř maloobchodní sítě v intraurbánní struktuře měst. Ze zkušeností z některých zemí v západní Evropě v minulosti víme, že dynamický rozvoj velkoplošné maloobchodní sítě přinesl mnohé problémy ve fungování městského organismu a že vznikla reálná potřeba regulací v maloobchodě. Výstavba hypermarketů, a později velkých nákupních center na periferiích měst, vyvolala řadu negativních efektů jak v samotné maloobchodní sítí, tak v dopravě a dostupnosti maloobchodu, až po destrukce městských funkcí (např. umrtvování městských center). Na druhou stranu začaly nadnárodní společnosti provozující sítě velkoplošných prodejen přenášet na trh nová ekonomická pravidla, plynoucí z jejich ekonomické síly.

Posilující dominance nadnárodních maloobchodních firem začala narušovat podmínky na trhu a stala se reálnou hrozbou pro menší maloobchodní firmy. Obavy z narušení tržních podmínek a nekalých praktik velkých ekonomických subjektů v maloobchodním prostředí jsou dalším aspektem nutnosti přistoupení k regulaci odvětví maloobchodu. Patří k nim i environmentální důvody, nebot' každá realizace velkoplošné prodejny v území natrvalo degraduje životní prostředí (čím větší prodejny, tím zpravidla větší environmentální dopady do území). Potenciální degradace životního prostředí (zábor půdy nebo ochrana vod) v souvislosti s předpokládanou výstavbou velkoprodejny vyvolává ve společnosti citlivé negativní reakce na narušování podmínek jejich životního prostředí a velmi často se společnost staví na odpor. Následující čtyři důvody pro regulaci a plánování maloobchodu jsou dobrou ukázkou širokospektrálního pohledu na danou problematiku (Spilková, 2012a): 
- Maloobchod: volná ruka trhu musí být pečlivě kontrolována, aby bylo zabráněno přehnanému rozvoji obchodů a aby byl dosažen optimální mix typů obchodů na různých úrovních maloobchodní hierarchie.

- Město: plánování maloobchodu by měla být věnována patřičná péče kvůli vlivu, který mají maloobchodní zařízení na doplňkové využití území a městskou morfologii. Vitalita městského centra je závislá na síti interakcí mezi rozličnými městskými funkcemi.

- Sociální plánování: nutnost plánování v maloobchodě je dána imperativem neznevýhodňování některé ze socioekonomických skupin v př́stupu k maloobchodu.

- Životní prostředí: v plánování maloobchodu by mělo dojít k jeho oddělení od odlišných a vzájemně neslučitelných funkčních ploch a minimalizovat dopad nové maloobchodní výstavby na životní prostředí člověka.

Regulativa v plánování maloobchodu mají rozdílnou formu v různých zemích (Szczyrba, 2005; Mitríková, 2008; Spilková, 2012a). Některé státy uplatňují restriktivnější politiku, jiné přistupují k plánování maloobchodu méně přísně. Nejčastěji se regulace opírá o stanovení velikostních limitů pro novou výstavbu velkoplošných prodejen a konkrétní lokaci ve městě.

Plánování maloobchodu má v západní Evropě dlouhou tradici a vyvíjelo se postupně do 70. let minulého století. Zatímco v Německu, Belgii nebo ve Francii došlo $v$ tomto období $k$ rozvolnění plánování a $\mathrm{k}$ první větší vlně výstavby velkoplošných prodejen i v lokalitách na periferiích měst, v Nizozemsku, Velké Británii nebo skandinávských zemích byla výstavba přísně regulována podle hierarchických stupňů maloobchodní vybavenosti ve městech. Na jihu Evropy převládala v maloobchodní síti jednotlivých zemí tradiční atomizovaná struktura maloobchodu s vysokým podílem menších prodejen.

Jak dále uvádí Spilková (2012a), v 80. letech minulého století se rozdíly v plánování maloobchodu u jednotlivých zemí ještě zvýšily. Začaly se objevovat první negativní dopady spojené s výstavbou velkoplošných prodejen, což vedlo k návratu restrikcí v plánování maloobchodu ze strany některých zemích (Německo, Belgie). Francie, která je "kolébkou hypermarketu“ (1963), musela dokonce přijmout zákon regulující dynamicky se zvyšující počet těchto velkoplošných formátů. Nizozemsko a skandinávské státy zůstaly u restriktivní plánovací politiky podobně jako Švýcarsko a Rakousko a nově se začaly objevovat negativní zkušenosti s výstavbou hypermarketů a jiných velkoplošných prodejen v Irsku, Španělsku a Portugalsku. Devadesátá léta minulého století byla ve znamení slad'ování regulačních politik pro oblast plánování maloobchodu.

V současnosti existují v západní Evropě v zásadě dva př́ístupy v regulaci maloobchodu (Spilková, 2012a):

i) na úrovni státu není žádná specifická legislativa a rozhodování provádějí místní dotčené plánovací úřady (Německo, Velká Británie, Skandinávie, Nizozemsko a další), 
ii) stát má k dispozici specifické zákony regulující novou výstavbu maloobchodu jakožto část legislativy v oblasti hospodářské soutěže (Francie, Belgie, Itálie, Španělsko).

Proces vyhodnocování vlivů plánované výstavby velkoplošných prodejen na maloobchodní sit i životní prostředí je založen ve většině zemí západní Evropy na předchozím zpracování př́ślušné dokumentace. Tou je vyhotovení dokumentace EIA (Environmental Impact Assessment) nebo RIA (Retail Impact Assessment). Zatímco první dokument je dnes základní podmínkou před každou větší stavbou, tedy nejen maloobchodní velkoprodejnou ( $\mathrm{v}$ ČR od velikosti tř́ tis. $\mathrm{m}^{2}$ zastavěné plochy), dokument RIA se týká výlučně vyhodnocování dopadů plánované výstavby maloobchodní prodejny určité velikosti na dopravu, městské funkce nebo podnikatelské prostředí. Velikostní kritéria pro vyhodnocování plánů na výstavbu maloobchodních prodejen i okruhy témat pro zpracování RIA se liší v rámci jednotlivých zemí. $V$ České republice není RIA součástí plánovacího procesu.

\section{Vývoj plánování v maloobchodě v ČR}

$\checkmark$ souvislosti s dynamickým rozvojem velkoplošného maloobchodu v České republice $v$ druhé polovině 90 . let se začaly objevovat první signály o přehliživém postoji nadnárodních maloobchodních řetězců vůči územnímu plánování, životnímu prostředí, resp. zesílily obavy malých prodejců, že vlivem nekontrolovaného vývoje velkoprodejen dojde k významnému omezení jejich podnikání či až ztrátě obživy.

Ptáme-li se na příciny masivní výstavby velkoplošných prodejen u nás, je třeba hledat odpověd'v koncepci územního plánu, který sehrává rozhodující úlohu v lokalizaci ekonomických aktivit do území. Spilková a Perlín (2010) považují za klíčový problém prípravu územního plánu a rozhodnutí o budoucí formě zastavěné oblasti a o její architektonické a funkční regulaci, tedy praxe pocházející z územního plánování v 80. letech minulého století. První územní plány v 90. letech tak představovaly seznam potenciálních volných pozemků, které mohou být využity, budou-li dodrženy základní podmínky ochrany. Developerům se otevírala snadná cesta k rozvoji svých maloobchodních plánů, navíc jim nebyly kladeny větší překážky ze strany obecních zastupitelstev.

Jak konstatují Spilková a Perlín (2010), všechny velké maloobchodní stavby vznikly v souladu s územním plánem, a tudíž bez jakýchkoliv problémů. Tam, kde k problémům došlo a města si kladla podmínky nad rámec představ maloobchodní firmy, bud'to odešla bez dohody do jiné lokality na území ČR, nebo k dohodě došlo, a to se sousední obcí a projekt velkoplošné prodejny byl realizován v těsné blízkosti administrativních hranic města (např. Makro ve Velké Bystřici u Olomouce). Vše opět v souladu se stavebním zákonem.

Zcela bezprecedentní situace byla v Praze, které až do roku 1999 chyběl územní plán a praxe $v$ plánování maloobchodu byla založena na vydávání opatření jednotlivými městskými částmi. Získat rozvojové pozemky nebyl tehdy žádný 
problém a dnešní situace, po změně př́slušné legislativy (stavební zákon z roku 2006), se nijak významně nezměnila proti tehdejšímu stavu. Důvodem je stále chybějící legislativa na národní úrovni - stavební zákon v jeho územně plánovací části je nedostačující a obcím chybí jasná pravidla pro posuzování projektů chystané výstavy hypermarketů nebo nákupních center. Přitom podíváme-li se do okolních postkomunistických zemí regionu střední Evropy, Polsko i Mad’arsko vyžaduji jak zpracování studií EIA a RIA, tak si kladou tvrdé podmínky pro povolování nových komerčních zařízení (Spilková, 2012a).

Další príklad jen dokresluje nezvládnutý problém regulace a plánování maloobchodu v České republice, a to když v roce 1998 nechalo Ministerstvo průmyslu a obchodu ČR zpracovat metodickou př́ručku "Rozvoj a optimalizace dimenzí maloobchodních síti v území (odborný materiál pro obce)“. Takzvaná „žlutá brožura" měla nejen informovat obce o dosavadním vývoji maloobchodu v České republice, ale především jim poskytnout metodickou podporu a návod, jak „optimalizovat" maloobchodní sít na jejich území. Doporučení měla charakter stanovení předpokládané sortimentní struktury plošného standardu a umístění skladů velkoplošných prodejen v obchodním mixu na území obcí v horizontech let 2000 a 2010.

Jak se nakonec ukázalo, ani Ministerstvo průmyslu a obchodu ČR, ani mnohé renomované konzultační firmy $v$ oblasti maloobchodu nedokázaly predikovat skutečný rozsah výstavby na území státu. Vývoj byl daleko razantnější a přepokládaná „optima“ v metodické příručce byla překročena na mnoha místech České republiky daleko dříve, než bylo plánováno. Např́klad v Olomouci, kde byl prováděn průběžný monitoring maloobchodní sítě, byly již v roce 2005 překročeny předpokládané prodejní kapacity plánované až ke konci dekády (Szczyrba, 2005).

\subsection{Rozvoj velkoplošného maloobchodu v urbánním prostředí}

Jedno z klíčových témat, které vyvstaly po roce 1989 v souvislosti s transformací českého maloobchodu, byly změny v městské maloobchodní sítí a s tím spojená otázka nového urbanismu (Drtina, 1998; Körner, 1998). Hned na začátku transformačního období se ukázalo, že česká města nebyla vůbec připravena na tak dynamické změny, proto se hledala, velmi často chaoticky, řešení vzniklých situací. Jistou inspirací byly př́iklady ze zahraničí (zejména ty negativní), které přinesl překotný vývoj maloobchodu ve východoněmeckých městech (Kulke, 1997). Pořádaly se semináře, některá města začala dokonce mapovat svou maloobchodní sít (např. Brno a Hradec Králové), aby bylo možné kvalifikovaně stanovit prípadné regulace územního rozvoje maloobchodní sítě v nových podmínkách tržní ekonomiky. Jak známo, česká legislativa byla a stále je nedostačující pro plánování maloobchodu. Chybí povinnost investora předložit studii RIA, jejíž 
implementace do územního plánování by jistě dokázala účinně regulovat vývoj maloobchodní sítě a omezila by výstavbu velkoplošných prodejen na okrajích měst (Nagy, 1998; England, 2000). Vývoj byl ovšem převážně určován expanzivní politikou maloobchodních koncernů a retailového developmentu.

Relativně rychle, v souvislosti s výstavbou prvních hypermarketů a nákupních center $v$ periferních lokalitách měst, započal proces decentralizace maloobchodních funkcí v hierarchii maloobchodní vybavenosti těchto měst. Maloobchod $v$ městských centrech, kde mu tradičně patří důležitá funkce $v$ rámci urbánní struktury, začal postupně ztrácet své klíčové postavení. Na městské periferii a v prríměstském prostoru se začala formovat nová ohniska maloobchodu, která postupně rozšírila svou obchodní dimenzi o další neobchodní funkce (gastronomie, cestovní kanceláře, ordinace lékařů, multiplexy a další služby). Velmi dobře tuto skutečnost ilustrují následující dva příklady. Jedná se o město Brno, druhé největší město $v$ České republice a druhé po hlavním městě Praze co do investiční atraktivity. Druhým je regionální centrum Olomouc s dobrou dopravní polohou a atraktivitou pro maloobchodní řetězce danou svým obslužným regionem.

\section{Brno - proměny městské maloobchodní sítě}

Již v první etapě transformace maloobchodu na sebe město významně upoutalo pozornost zahraničních maloobchodních řetězců, které zde začaly rozvíjet svou mezinárodní obchodní sít'. $V$ roce 1996 se Brno stalo prvním městem na území České republiky, kde byla realizována výstavba velkého hypermarketu (Globus). Šlo o důležitý impulz k rozvoji velkoplošných maloobchodních jednotek nejen na území města. Jak uvádí Muliček (2004), dynamika rozvoje nových velkoplošných maloobchodních forem byla odlišná od ostatních měst $v$ ČR a jediné srovnatelné procesy se ve stejné době odehrály v Praze.

Data z posledního provedeného průzkumu maloobchodu v Brně v roce 2009 jasně ukazují, že dochází kontinuálně k provozní koncentraci maloobchodu na území města, který charakterizuje růst maloobchodní plochy při snižování počtu maloobchodních prodejen. Prodejní plocha ve srovnání s rokem 2006 vzrostla o $12 \%$ a počet prodejen ve stejném období klesl o $11 \%$. Adekvátně tomu vzrostla průměrná prodejní plocha ze 134 na $165 \mathrm{~m}^{2}$. Jak dále ukazují autoři studie (Mulíček, Osman, 2009), bylo v roce 2009 ve velikostní kategorii nad $5000 \mathrm{~m}^{2}$ koncentrováno již $30 \%$ celkové prodejní plochy na území města. Naproti tomu zastoupení nejmenších prodejen do $50 \mathrm{~m}^{2}$ stále klesalo a ve sledovaném roce 2009 byl jejich podíl pouze $11 \%$.

Sledujeme-li vývoj plošného standardu v období transformace maloobchodní sítě Brna, pak i ten rostl v souladu s růstem prodejních ploch. $V$ roce 2009 dosahoval plošný standard úrovně $1780 \mathrm{~m}^{2}$ (bez započtení vnějšího nákupního spádu). Výrazným způsobem se změnila také sortimentní struktura plošného standardu, která v období socialismu měla víceméně vyrovnané zastoupení potravinářských 
a nepotravinářských prodejen. $\mathrm{V}$ roce 2009 již převažovaly prodejny nepotravinářského zboží, jejichž podíl na maloobchodní síti Brna dosahoval 80 \%.

$Z$ výše uvedeného je zřejmé, že transformace maloobchodu v Brně byla během posledních dvaceti let doprovázena velkými prostorovými změnami. Výrazné změny nastaly ve vnitřním městě a v okrajových lokalitách, zejména v periferní suburbánní zóně Brna. Od roku 1997 zde několikanásobně vzrostly prodejní kapacity. Za povšimnutí stojí rozsáhlá výstavba velkých nákupních center a dalších velkoprodejen na okraji města, které zvýšily plošný standard na více než $5000 \mathrm{~m}^{2}$. Více o velkoplošných prodejnách v Brně v další kapitole.

Obr. 4.9: Prodejní plochy v územní struktuře města Brna v letech 1997 a 2009 ( $v$ prepočtu na 1000 bydlících obyvatel podle morfogenetických zón města)

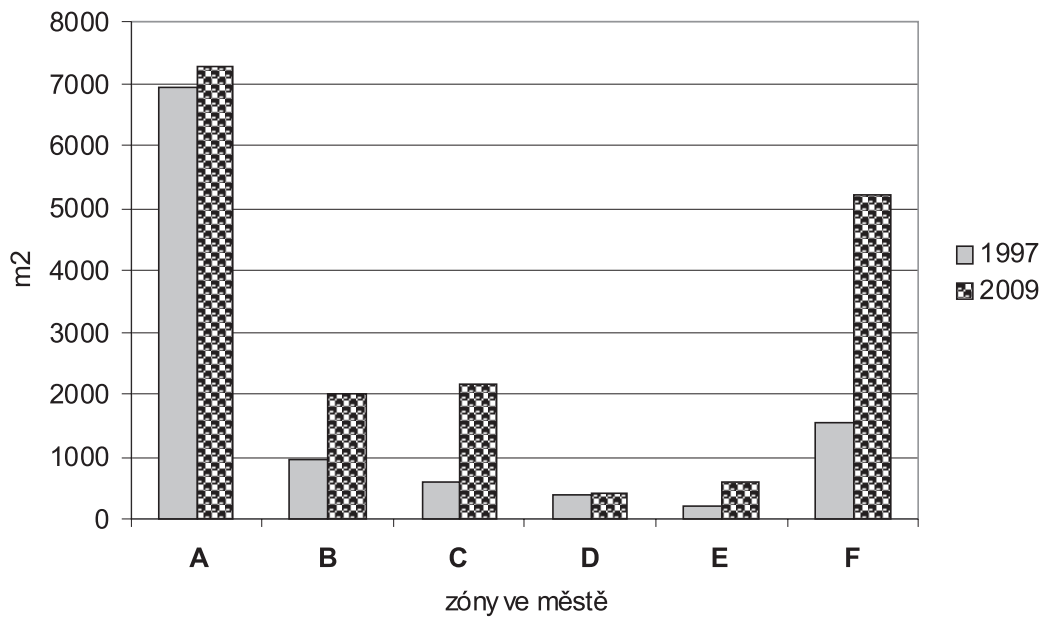

Zdroj: Muliček, Osman (2009).

Pozn.: zóny města: $A$ - centrum, $B$ - vnitřní město, $C$ - širši vnitřní město, $D$ - vilové čtvrti, $E$ - sídliště, $F$ - suburbánní zóna

\section{Olomouc - proměny městské maloobchodní sítě}

Olomouc, páté největší město České republiky (100 tis. obyvatel), vykazuje shodné znaky transformace maloobchodu jako Brno a další velká česká města. Pouze s tím rozdílem, že vývoj velkoplošné maloobchodní sítě byl oproti jiným velikostně srovnatelným městům (Liberec, České Budějovice ad.) o několik let zpožděn, jelikož prvními obsazovanými lokalitami byla největší česká města a regionální centra západně od moravského sídelního prostoru (vývoj na principech expanzivní hierarchické a kontaktní difúze). 
Reálně až do roku 1997 byla maloobchodní sít města Olomouce silně atomizovaná s omezeným podílem velkoplošné maloobchodní sítě a minimálním zastoupením zahraničních obchodních společností. Maloobchod se z hlediska nabídky i mobility obyvatel soustřed'oval zejména do historického centra města. Tato část byla ještě v roce 1998 nejdůležitějším místem maloobchodní nabídky ve městě, když koncentrovala až $35 \%$ prodejních ploch ve městě a $38 \%$ prodejních jednotek (Szczyrba, 2005).

První velkoplošná prodejna zahraničního maloobchodního řetězce byla v Olomouci otevřena v roce 1996 (hobbymarket bauMax). První komerční suburbánní lokalitou byla lokalita Horní lán na jihovýchodním okraji města (blízko sjezdu z R 46 směr Prostějov-Brno), kde byl v roce 1997 otevřen první hypermarket na území Olomouce (Terno). Nejen v lokalitě Horní lán, ale i v jiných lokalitách ve městě byly zprovozněny další velkoprodejny zahraničních maloobchodních řetězců (viz tabulka 4.2). Tato nová situace zásadně ovlivnila celkovou transformaci a restrukturalizaci městské maloobchodní sítě, včetně prostorové reorganizace maloobchodu i nákupního chování obyvatelstva.

Tab. 4.2: Rozvoj velkoplošných prodejen nad $3000 \mathrm{~m}^{2}$ na území Olomouce a jeho zázemí po roce 1989

\begin{tabular}{|c|c|c|c|c|}
\hline název velkoprodejny & $\begin{array}{c}\text { rok } \\
\text { otevření }\end{array}$ & lokalita & $\begin{array}{c}\text { prodejní } \\
\text { plocha } v \mathrm{~m}^{2}\end{array}$ & prodejní formát \\
\hline bauMax & 1996 & vnitřní město & 4000 & hobbymarket \\
\hline Terno** & 1997 & periferie & 3000 & hypermarket \\
\hline $\mathrm{OBI} * *$ & 1999 & periferie & 7000 & hobbymarket \\
\hline Makro & 1999 & $\begin{array}{l}\text { sousední obec } \\
\text { (Velká Bystřice) }\end{array}$ & 10000 & $\begin{array}{l}\text { cash \& carry market } \\
\text { (hypermarket) }\end{array}$ \\
\hline Globus* & 2000 & periferie & 15000 & hypermarket \\
\hline Kaufland & 2001 & vnitřní město & 3500 & hypermarket \\
\hline OC Haná** & 2002 & periferie & 11500 & $\begin{array}{l}\text { nákupní centrum } \\
\text { (Tesco) }\end{array}$ \\
\hline Olympia & 2004 & $\begin{array}{l}\text { Sousední obec } \\
\text { (Velký Týnec) }\end{array}$ & 30000 & $\begin{array}{l}\text { nákupní centrum } \\
\text { (HyperAlbert) }\end{array}$ \\
\hline Olomouc City* & 2005 & periferie & 24500 & $\begin{array}{l}\text { nákupní centrum } \\
\text { (Globus) }\end{array}$ \\
\hline Hornbach & 2007 & vnitřní město & 10000 & hobbymarket \\
\hline $\begin{array}{l}\text { Asko, GigaSport, } \\
\text { Electro World ** }\end{array}$ & 2005 & periferie & 16000 & retail park \\
\hline Galerie Moritz & 2012 & centrum města & 8400 & nákupní centrum \\
\hline Galerie Šantovka & 2012 & vnitřní město & 46000 & nákupní centrum \\
\hline
\end{tabular}

Zdroj: Vlastní šetrení.

Pozn.: * komplex nákupního centra Olomouc City

** velkoplošné prodejny v lokalitě Horní lán 
Významně do maloobchodního systému Olomouce zasáhlo otevření regionálního nákupního centra Olympia v příměstské zóně na území sousední obce Velký Týnec. I když jde o lokalizaci mimo administrativní hranice města (podobně jako v prípadě Olympie $v$ Modřicích u Brna), jedná se o funkčně propojenou provozní jednotku s olomouckou maloobchodní sítí (kyvadlová doprava mezi nákupním centrem a centrem města Olomouce), a je tak nutné počítat toto nákupní centrum do celkové bilance maloobchodu ve městě. V srpnu 2005 byl otevřen třetí koncept nákupního centra ve městě, a to nákupní centrum Olomouc City, které rozšírilo původní prodejní kapacitu hypermarketu Globus o zhruba 25 tis. $\mathrm{m}^{2}$. Součástí centra je multikino se sedmi kinosály, lékařské ordinace a dalších 70 prodejních jednotek v nákupní galerii. Tento projekt je zatím největším v oblasti nákupních center na střední Moravě. Na rok 2013 je ovšem plánováno otevření nového maloobchodního gigantu v blízkosti historického jádra - nákupního centra Galerie Šatovka. Hrubá pronajímatelná plocha má dosáhnout 46 tis. $\mathrm{m}^{2}$ a v nabídce má být zhruba 180 nových prodejních jednotek a 1000 parkovacích míst.

Když byla v roce 2002 naposledy provedena pasportizace maloobchodní sítě (Szczyrba, 2002), ukázalo se, že významně své pozice v maloobchodní síti Olomouce ztratilo městské centrum (pokles podílu na $20 \%$ ). Z hlediska sortimentní struktury převažovaly již nepotravinářské prodejny, mezi nimiž nejvýrazněji rostl podíl prodejen s oblečením. Postupně ale vývoj v městském centru Olomouce viditelně ovlivnily procesy secondhandizace a asiatizace maloobchodní sítě, které patří mezi další viditelné rysy současné transformace maloobchodu ve městě (Szczyrba, 2005). Nejnověji byla na konci roku 2012 otevřena Galerie Moritz, která představuje úspěšnou revitalizaci obchodního domu Prior v centru města (zvýšení prodejní plochy z 5000 na 8400 m²).

V souvislosti s otevřením výše zmíněné Galerie Šantovka, která se stane svojí prodejní plochou největším nákupním prostorem v Olomouci (viz tabulka 4.2), dojde zároveň s největší pravděpodobností k narušení intraurbánních vazeb $v$ městském maloobchodním systému, a to nejen vlivem velikosti tohoto nákupního centra, ale i omezením prodejních kapacit v některém z olomouckých nákupních center na periferii města. Stávající obchodní dimenze Olomouce budou významně překročeny a bude nutné redukovat prodejní plochy. Ve hře je také částečné „umrtvení“ obchodní funkce městského centra, což je jev, který není v západní Evropě neznámý (např. Marjanen, 2005; Crosby et al., 2005) a který se jeví jako jeden z reálných scénářů dalšího vývoje, právě díky umístění velkokapacitního nákupního centra Galerie Šantovka v lokalitě na styku s městským centrem (městskou památkovou rezervací). 


\subsection{Shrnutí}

Změny, kterými prošel maloobchod $v$ České republice během posledních dvaceti let, byly významně ovlivněny internacionalizací odvětví. Velké nadnárodní firmy v relativně rychlém čase uskutečnily svými velkoplošnými prodejními koncepty zcela zásadní změnu prostorově-funkčního modelu města (Matlovič et al., 2001; Sýkora, 2003; Mulíček, 2004, 2007). Šlo o vývoj, který znamenal decentralizaci maloobchodních funkcí a iniciaci nových jader maloobchodní vybavenosti na městské periferii, jež odpovídají současnému prostorovému modelu postindustriálního města (Knox a Pinch, 2000; Hall, 2001).

Podobně jako v mnoha zemích na západ od hranic České republiky se začínají ve zdejším urbánním prostředí etablovat nové prostorově-funkční prvky představující mix obchodních a neobchodních funkcí a rozšiřující vliv multifunkčních velkoplošných prodejních formátů na utváření nákupního chování (Pacione, 2009; Heineberg, 2006). Současně s tím pozorujeme rozvoj velkých nákupních center v př́městských lokalitách, které významně napomáhají prostorovému rozpínání města do okolní krajiny (Sýkora, 2003; Mulíček, 2007; Andráško, Biolek, 2011). Tento vývoj, označovaný jako komerční suburbanizace, je v současné době viditelný ve většině krajských měst České republiky a pochopitelně nejvíce v hlavním městě Praze, která představuje „výkladní skřrin“" všech klíčových změn urbánního prostředí vlivem transformace maloobchodu v České republice během posledních dvaceti let.

V obecné rovině poznání dosavadního vývoje maloobchodní sítě v území se současná etapa expanze dostává do fáze prostorové koncentrace, kterou charakterizuje sílící posun ve vertikálním směru od větších sídel $k$ menším. $V$ praxi se tak velkoformátové prodejny typu hypermarketů (menší formáty), hobbymarketů či retail parků posouvají do menších středisek, diskontní řetězce prakticky do všech obchodně významných středisek pro odbyt jejich zboží (města i pod hranicí 5 tis. obyvatel). Jiným efektem prostorové koncentrace maloobchodních funkcí je současný přesun investorských aktivit z městských periferních lokalit, kde fungují četná nákupní centra, do centrálních lokalit (Cushman \& Wakefeld, 2012; EIA). Dochází zde nejen k nové výstavbě, ale stále častěji také k revitalizaci objektů (včetně brownfieldů) z doby před rokem 1989 (např. nákupní centra Nový Smíchov v Praze, Galerie Vaňkovka v Brně, Galerie Moritz v Olomouci nebo Breda \& Weinstein v Opavě - revitalizace bývalého pivovaru). Jde o novou vinu výstavby nákupních center poté, co došlo k vyčerpání maloobchodních investic na městské periferii. 



\section{Nákupní centra a jejich specifika}

\subsection{Vývoj a současný stav nákupních center se zaměřením na Českou republiku}

Za předchůdce nákupních center Ize s určitou nadsázkou považovat obchodní domy, které znamenaly skutečnou změnu ve způsobu nakupování. Za patrně nejstarší obchodní dům je považován Le Bon Marché v Paříži, založený roku 1838 jako malý obchod a přestavěný do podoby obchodního domu po rozsáhlé rekonstrukci k roku 1887. Obchodní dům byl poprvé otevřen pro všechny společenské vrstvy, zákazníci nebyli nuceni koupit konkrétní zboží, měli volnost pohybu a výběru, mohli zboží vrátit a novinkou byla také donáška do domu a občasné slevy (Klaffke, 2003; Coleman, 2006). Koncept obchodního domu a pozdějších obchodních či nákupních center se stal jedním z nástrojủ hlubších společenských a ekonomických změn, jež znamenaly obrat od nákupů $z$ "nutnosti“ k nákupům pro zábavu. Lidé se mohli začít odlišovat, zvýraznila se jejich osobní identita a začaly být uspokojovány více než pouze základní lidské potřeby (Schiffmann et al., 2004).

Snižující se ceny průmyslově vyráběného zboží, ale i jeho rostoucí kvality způsobily, že konzumní způsob života se dostal nejen do všech koutů Evropy a Severní Ameriky, ale také téměř ke všem společenským třídám. Tomuto vývoji také pomohl fakt, že se během 19. století zvýšil počet majetných lidí. Vyšší třída dávala na odiv své bohatství luxusním vybavením svých domů i šatníků - věk konzumního způsobu života mohl začít (Timothy, 2005).

Koncem 19. století byla ve vyspělém světě budována a modernizována infrastruktura. V centrech amerických (New York, Chicago) i evropských (Londýn, Paříž, Berlín ad.) měst na sebe nenechala dlouho čekat také výstavba nových nákupních center (Timothy, 2005). Definice nákupního centra (viz níže) není nijak jednoznačná, proto je také poměrně obtižné zpětně stanovit vznik prvních nákupních center, která by rámcově odpovídala daným parametrům. Wrigley (2003) považuje za jedno z prvních nákupních center Market Square v Chicagu (1916), jež bylo nekryté a připomínalo spíše skupinku obchodů stojících vedle sebe. Mezinárodní asociace obchodních center (International Council of Shopping Centers, dále také ICSC) považuje za první moderní nákupní centrum Highland Park Shopping Village $v$ Dallasu, které bylo vybudováno $v$ roce 1931 v unikátním mediteránním španělském stylu. Tato centra přirozeně disponovala parkovišti, připojen byl také stále oblíbenější supermarket a drogerie.

Během 1. světové války a zejména po ní prošla společnost výraznou proměnou. Střední měštanská třída značně narostla a zbohatla, došlo k první významnější emancipaci žen, které se aktivně zapojily do dění, jež patřilo dříve výhradně 
mužům. Změnil se také způsob odívání, velmi rychle se ujal nový sportovnější a pohodlnější styl, který naplnil vznikající obchodní domy a nákupní centra nejen ve světovém městě módy - v Pařiži, ale postupně po celé Evropě a Severní Americe (Fukai, 2006).

\section{Obr. 5.1: Jeden z prvních obchodních domů světa - Le Bon Marché v Paříži}
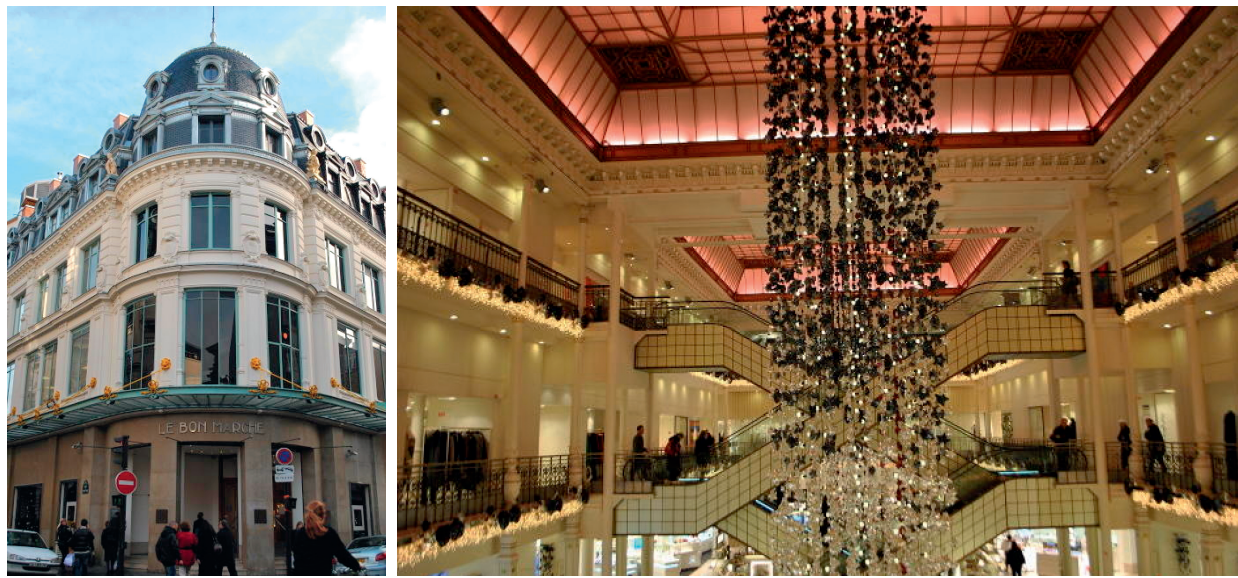

Zdroj: http://pariz-pro-pokrocile.blog.cz/1202/obchodni-dum-le-bon-marche.

Dalším mezníkem ve vývoji nákupních center byla 2. světová válka a 50 . léta. Zatímco se Evropa potýkala s poválečnou reparací a obnovovala především průmysl a bydlení, válkou nezničené USA zažily rychlý rozvoj téměř okamžitě po jejím skončení. Celková prosperita, rychlé bohatnutí země a rozšíření nabídky produktů mělo za následek další šíření konzumního chování. Po válce nastal také velký baby boom a obyvatelstvo, které mělo k dispozici nejnovější automobily, opouštělo přeplněná města a stěhovalo se do satelitních městeček na periferii a s nimi se stěhovala také nákupní centra. Vznikl tak nový koncept s názvem mega mall, umístovaný na okraje měst v návaznosti na rozsáhlé městské aglomerace ${ }^{14}$ (Buttler, 1991).

Za první předměstské nákupní centrum v USA a zřejmě i ve světě je považováno Northgate v Seattlu. Toto původně nezastřešené nákupní centrum s 18 obchody bylo otevřeno r. 1950 a mělo k dispozici také parkovací plochy a divadlo. 
V této době vznikala také první plně zastřešená nákupní centra, v r. 1955 bylo dokončeno Valley Fair Shopping Center v americkém Appletonu, které samo sebe označilo jako první nákupní centrum, které dokáže kontrolovat počasí. Hned o rok později bylo vybudováno Southdale Center v Edině, což bylo první zastřešené centrum regionálního významu, které přivedlo kontrolu vnitřního prostředí o úroveň výš, a to díky termostatu, který zde udržoval teplotu $24{ }^{\circ} \mathrm{C}$. Toto nákupní centrum pořádalo také různé události, např. koncerty či plesy (Coleman, 2006).

\section{Obr. 5.2: Jedno z prvních krytých nákupních center na světě - Northgate v Seattlu}

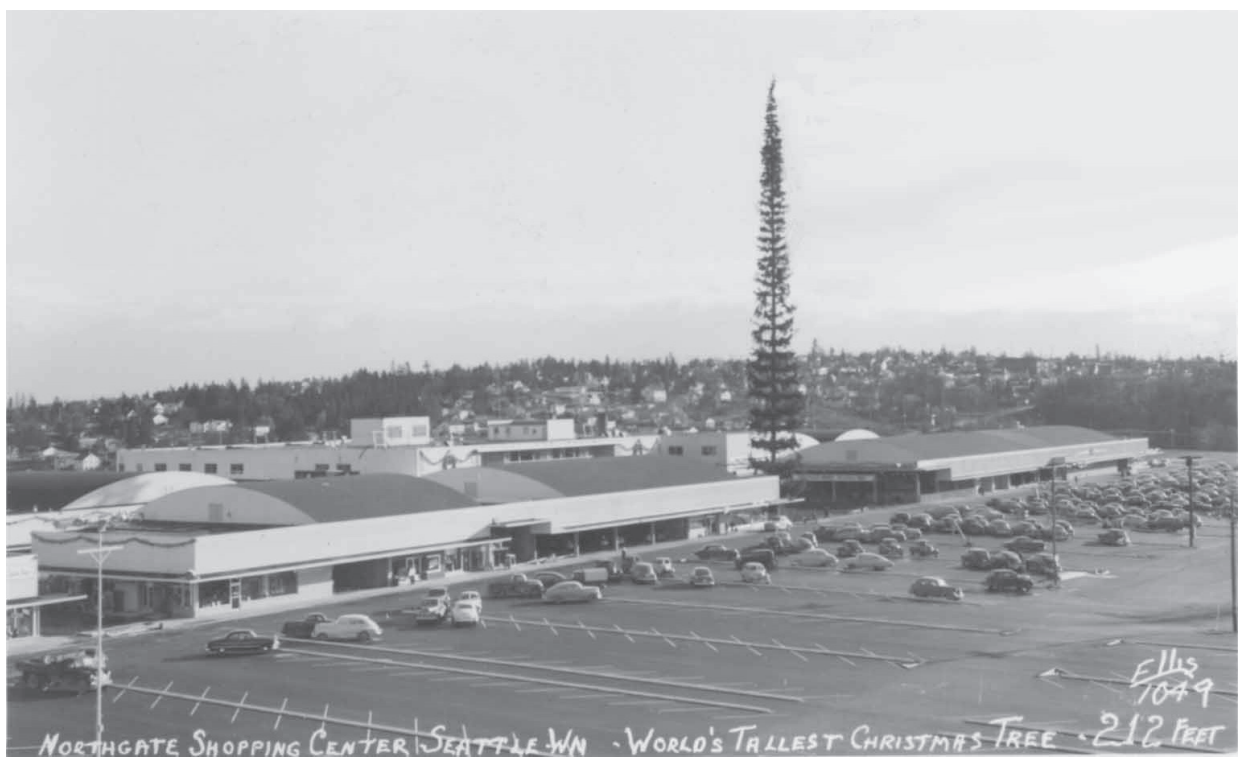

Zdroj: http://blsciblogs.baruch.cuny.edu/his1005fall2010/2010/11/16/one-stop-shop/.

V Evropě přišla vlna budování moderních nákupních center až počátkem 60. let, klíčovými hráči byla první dvě krytá centra ve Velké Británii i v celé Evropě: Bull Ring Centre v Birminghamu (1964) a Elephant and Castle v Londýně (1965), které se řadí dodnes k nejnavštěvovanějším nákupním centrům ve Velké Británii (Dawson, Lord, 2012). Obecně byla v Evropě nákupní centra menší a nedošlo zde $k$ tak rozsáhlé výstavbě na zelené louce ani $k$ vylidnění center jako v USA. V 60. letech se v západní Evropě stavěla nákupní centra na zelené louce především v blízkosti velkých dálničních křižovatek, přičemž se jednalo o jednopodlažní stavby. PIně se $v$ této době začala prosazovat pásová výroba a $s$ ní spojená rostoucí spotřeba, vznikaly nové technologie a materiály (Fukai, 2006). 
Díky snaze vynálezců, architektů a developerů neustále posouvat pokrok kupředu nabral vývoj nákupních center rychlý spád. Téměř každé nové nákupní centrum překonávalo to předešlé.

Významná výstavba nákupních center probíhala i v severských zemích, a to formou nezastřešených pěších ulic mezi objekty a v návaznosti na stanice metra. Samozřejmostí bylo přízemní parkoviště (Scott, 1970; Szczyrba, 2005). Později se výstavba na zelené louce přesunula do intravilánů měst a do satelitních městeček. Ohledy byly brány i na zákazníky nevlastnící auto. Centra byla dvoupodlažní a uvnitř vznikaly hotely, zóny volného času a jiná zařízení, která mohla být využita i jiným způsobem než jen jako prodejní jednotka ${ }^{15}$ (Guy, 1998b; Pražská, Jindra, 2002).

$\checkmark$ další etapě v 80. a 90. letech byla v západní či severní Evropě preferována většinou centra o střední velikosti prodejní plochy v rozmezí 20-40 tis. $\mathrm{m}^{2}$. Vývoj pokračoval $v 90$. letech zejména modernizací či rozšiřováním již postavených center a také transformací. Zábavní parky a možnosti využití volného času, restaurace, multikina apod. se staly nutným standardem, výjimkou již nebylo etážové parkování. Zatímco v ekonomicky vyspělých zemích tak byly spíše vyplňovány mezery na trhu ve spojení s širíi nabízených aktivit mimo obchod a nebyl kladen důraz na pouhý růst pronajímatelné plochy, $v$ tranzitních zemích střední a v posledních letech i východní Evropy nastal téměř nekontrolovatelný boom.

Obchodní zóny $v$ centrech měst dříve vznikaly bez předešlého plánování, zatímco dnešní nákupní centrum je (resp. mělo by být) předem plánovaným záměrem. Jeho velikost by měla odpovídat velikosti kupní síly ve spádové oblasti, nabízený sortiment by měl být dostatečně atraktivní, aby přilákal poptávku. $\checkmark$ České republice i dalších postsocialistických zemích se nákupní centra etablovala až ve 2 . polovině 90 . let a jejich skutečný rozmach nastal až v minulém desetiletí, tedy s více než čtyřicetiletým odstupem za ekonomicky vyspělou Evropou.

Dynamika vstupu a šíření tohoto nového prodejního konceptu však byla o poznání rychlejší než v USA nebo západní Evropě (důvodem byla především tehdejší výrazná podvybavenost prodejními plochami, ale i počáteční vstřícnost vůči zahraničním investorům), a to se všemi doprovodnými neduhy, spojenými např. s nedokonalým územním plánováním a průzkumem trhu či s negativním dopadem na sociokulturní i fyzické prostředí a výraznými změnami v nákupním chování obyvatel (viz např. Kok, 2007).

Po vstupu zahraničních řetězců na český trh a zavedení moderních maloobchodních formátů (supermarket, hypermarket, diskont) začala na konci 90. let Česká republika přitahovat i developery velkých nákupních center, která byla 
v tržním prostředí západní Evropy již dávno známým fenoménem. Rozvoj nákupních center je totiž do značné míry podmíněn stabilním politickým prostředím hostitelského trhu, což byla Česká republika schopna nabídnout až necelých 10 let po pádu komunismu (Szczyrba, 2005). Prvním moderním nákupním centrem v České republice se stalo Centrum Černý Most v Praze, které bylo otevřeno $v$ roce $1997 .{ }^{16} \mathrm{~V}$ dalším roce byly uvedeny do provozu např. nákupní centra Průhonice, Borská Pole v Plzni či Avion Shopping Park v Brně. Vývoj a dynamika výstavby nákupních center jsou uvedeny na obrázku 5.3.

Počet nákupních center se od roku 1997 každoročně postupně zvyšoval, přičemž výstavba kulminovala v letech 2005-2008 (vrchol ekonomické konjunktury). Poslední tři roky jsou ve znamení útlumu ve výstavbě center, přičemž důvodem není jen celosvětová ekonomická krize.

Obr. 5.3: Vývoj výstavby nákupních center v České republice v letech 1997-2012

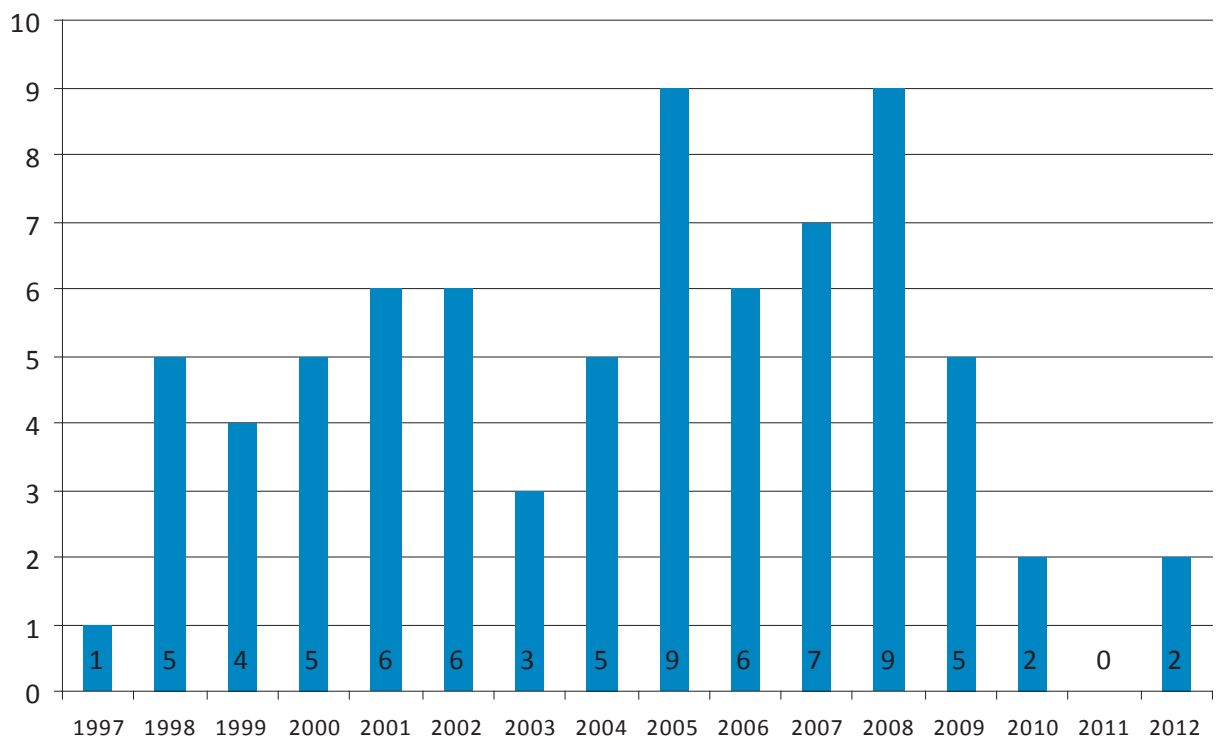

Zdroj: Centers DATA, 2010. Webové stránky jednotlivých center, tiskové zprávy, vlastní šetrení. 
V roce 2010 byla otevřena pouze dvě nákupní centra, a to Galerie Harfa v Praze a Chomutovka v Chomutově. Do poloviny roku 2011 nebylo v ČR, podobně jako v dalších deseti evropských zemích (mj. i v blízkém Rakousku a Mad’arsku), otevřeno žádné nové nákupní centrum. Až v listopadu téhož roku pak zahájilo provoz menší OC Lihovar v Říčanech, jehož rozloha 3,4 tis. $\mathrm{m}^{2}$ pronajímatelné plochy nesplňuje parametry mezinárodní definice (viz dále), a proto ho do našeho seznamu nezařazujeme. $V$ roce 2012 byly uvedeny do provozu dvě nová nákupní centra - Nová Karolina v Ostravě $\left(55\right.$ tis. $\left.\mathrm{m}^{2}\right)$ a pred koncem roku Breda \& Weinstein v Opavě (26 tis. $\left.\mathrm{m}^{2}\right)$, které ještě není zcela zaplněno. Přestože je aktuálně výstavba nových nákupních center slabá, investoři ve velkém nakupují retailové nemovitosti. Předpokládá se, že objem investic do maloobchodu přesáhne v roce 2012 o celou třetinu doposud nejsilnější rok 2007.

Regionální rozmístění nákupních center je nerovnoměrné a je primárně odrazem hierarchického postavení měst v sídelním systému. Proto nepřekvapí, že nejvíce nákupních center je v hlavním městě, tedy v Praze (19), dále v Jihomoravském kraji ( 8 , z toho 7 v Brně) a Moravskoslezském kraji ( 8 , z toho 5 v Ostravě).

Dalším kritériem při rozhodování developera o výstavbě nového nákupního centra je, mimo koupěschopnost obyvatel v rámci velkých městských aglomerací, i exponovaná poloha, např. vůči státní hranici, jako je tomu v případě Liberce. Zde se uplatňuje mj. i zájem o nákupy vybraného levnějšího zboží z populačně silného zázemí Polska a Saska. $V$ př́padě Středočeského kraje, kde reálně nenalezneme s krajskými městy srovnatelná urbanizovaná území, je zřejmý vliv Prahy na lokalizaci nákupních center i v populačně menších sídelních útvarech blízko hlavního města (Říčany u Prahy, Čestlice). Celkový počet nákupních center splňujících mezinárodní parametry ICSC se pohybuje v České republice v roce 2012 kolem hodnoty 75.

Česká republika se s velkou pravděpodobností již ocitla za zenitem boomu výstavby nových nákupních center a, podobně jako mnoho dalších evropských zemí, bude hledat také jiná řešení (rozšiřování a modernizace stávajících center) či koncepty (retail parky, menší hypermarkety a supermarkety). V roce 2011 a 2012 byla v České republice otevřena de facto dvě větší nákupní centra a od roku 2008 pokračuje propad výstavby. V evropském kontextu je ČR (téměř $200 \mathrm{~m}^{2} \mathrm{GLA}^{17}$ v přepočtu na 1000 obyvatel - viz následující graf) ovšem stále pod průměrem zemí EU $27\left(237 \mathrm{~m}^{2}\right)$, a určitý prostor pro růst zde tedy stále zůstává. 
Obr. 5.4: Regionální rozmístění nákupních center v České republice (2012)

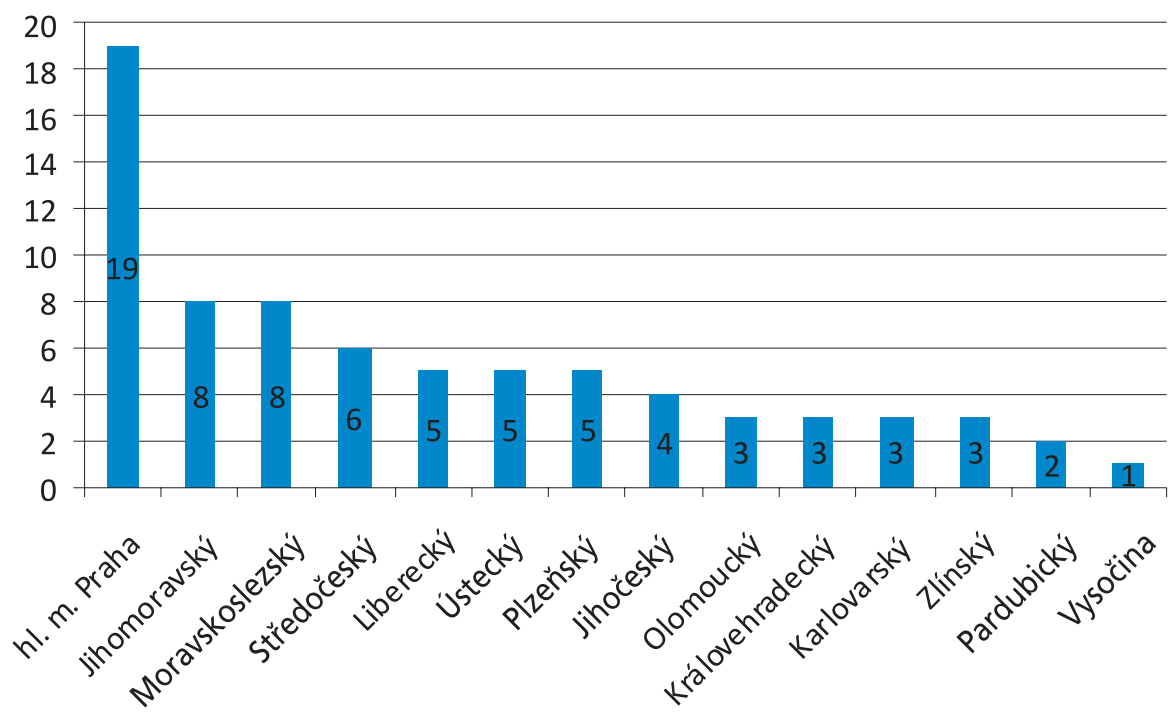

Zdroj: Centers DATA, 2010. Webové stránky jednotlivých center, tiskové zprávy, vlastní šetření.

Na tomto místě je vhodné čtenáři stručně představit situaci týkající se nákupních center $v$ České republice $v$ evropském kontextu. $V$ první polovině roku 2011 přibylo v Evropě 71 nových nákupních center k dosavadním zhruba 6,5 tisícům, což znamenalo 2,1 mil. $\mathrm{m}^{2}$ nové hrubé pronajímatelné plochy v nákupních centrech (Gross Leasable Area - GLA). Do konce roku 2011 je vývoj odhadován na 6,8 mil. $\mathrm{m}^{2} \mathrm{~s}$ tím, že druhá polovina roku bude, podobně jako $v$ minulých letech, výraznější. Oproti roku 2010 se jedná o predikovaný čtvrtinový nárůst. Rokem 2010 se s velkou pravděpodobností také zastavil pád vývoje GLA v nákupních centrech související s celosvětovou ekonomickou krizí po dlouhém období konjunktury (maximum v roce $2008-9,5$ mil. $\mathrm{m}^{2}$ ). $\mathrm{K}$ polovině roku 2011 dosáhla celková GLA v nákupních centrech v Evropě 135 mil. m² (Cushman \& Wakefield, 2011). 


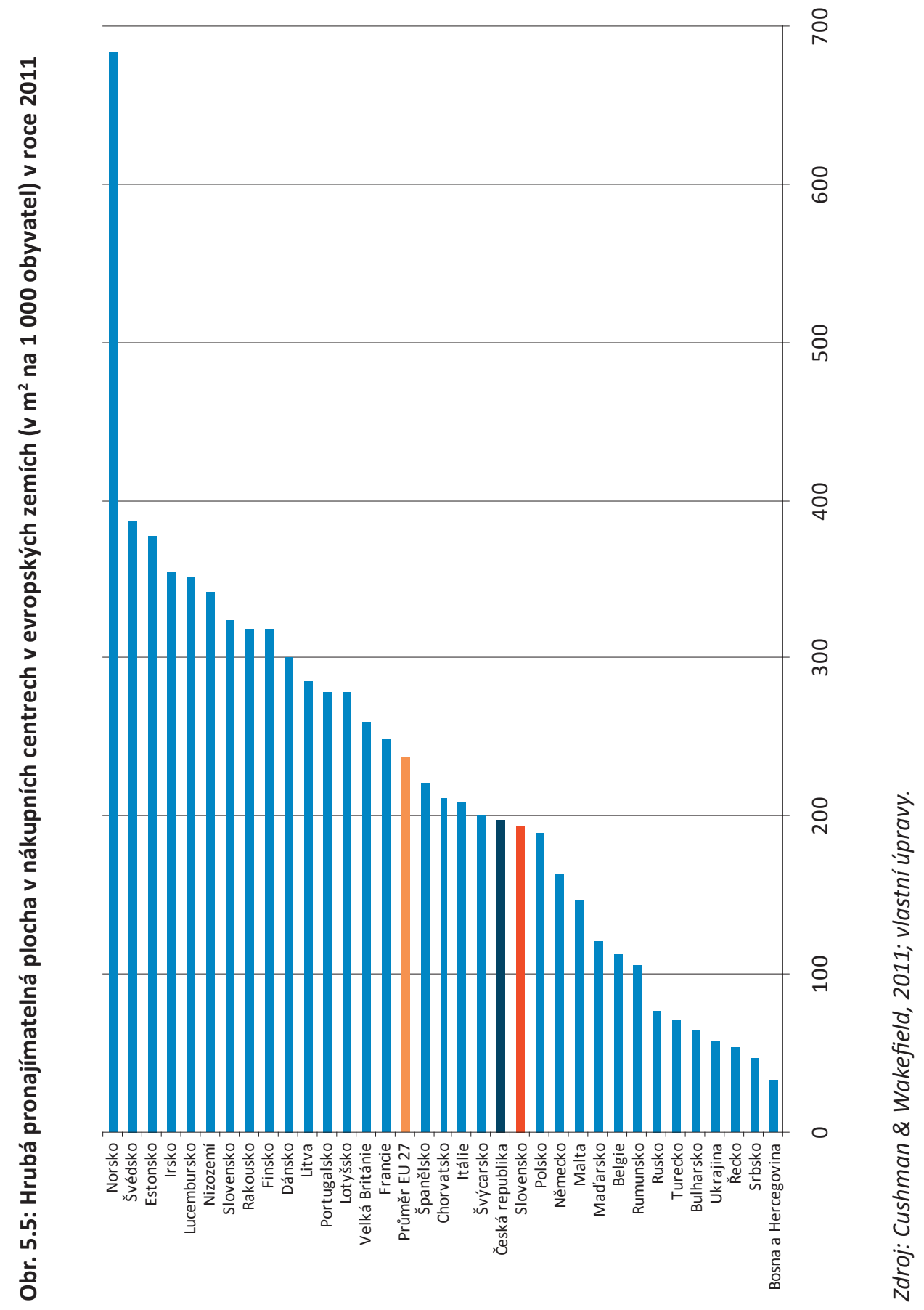


Zhruba 90 \% kapacit nákupních center je lokalizováno v západní Evropě, zbylých 10 \% připadá na střední a východní Evropu. Tato situace se však bude postupně vyrovnávat $v$ souvislosti s přesunem stavebního boomu ze západu na východ. Pro druhou polovinu roku 2011 a rok 2012 si podle renomované realitní společnosti Cushman \& Wakefield jen Rusko a Turecko připíší asi 40 \% z celoevropského účtu nové plochy nákupních center, přičemž trh není zdaleka nasycen ani na Ukrajině, v Polsku, Rumunsku, Bulharsku a většině zemí bývalé Jugoslávie. Převaha nově budovaných konceptů nákupních center ve východní Evropě a zejména v Rusku a Turecku je zřejmá i z následující tabulky. Rozlohou největší nákupní plochu si ovšem připsalo londýnské Stratford city.

Tab. 5.1: Největší projekty nákupních center v Evropě v letech 2011 a 2012

\begin{tabular}{|l|l|l|c|c|}
\hline Stát & Město & Název NC & GLA v m & $\begin{array}{c}\text { Rok } \\
\text { otevření }\end{array}$ \\
\hline Velká Británie & Londýn & Stratford City & 176500 & 2011 \\
\hline Rusko & Krasnodar & OZ mall & 163000 & 2011 \\
\hline Španělsko & Zaragoza & Puerto Venecia & 123500 & 2012 \\
\hline Rusko & Ufa & MEGA Ufa & 114700 & 2011 \\
\hline Rusko & Samara & MEGA - Samara & 103000 & 2011 \\
\hline Turecko & Istanbul & Marmara park & 100000 & 2012 \\
\hline Slovinsko & Ljubljana & Sportni Park Stožice & 96300 & 2012 \\
\hline Itálie & Villesse & Villesse Shopping & 90000 & 2012 \\
\hline Turecko & Istanbul & IspartaKule & 85000 & 2012 \\
\hline Chorvatsko & Zagreb & Supernova Zagreb & 80000 & 2012 \\
\hline Rusko & St. Petersburg & Leto & 77700 & 2011 \\
\hline Rusko & Nižnyj Novgorod & Nebo & 75000 & 2012 \\
\hline Rusko & Perm & SC Speshilova & 75000 & 2012 \\
\hline Rusko & Tjumen & Tjumen & 75000 & 2012 \\
\hline
\end{tabular}

Zdroj: Cushman \& Wakefield, 2011, 2012; vlastní úpravy.

\subsection{Definice a členění nákupních center}

Obecná definice nákupního centra je podle Mezinárodní asociace nákupních center následující: nákupní centrum je soubor maloobchodních a jiných obchodních zařízení, který je plánován, postaven, vlastněn a řízen jako jeden celek, typicky $s$ vlastní možností parkování. Nejčastější kombinací je nákupní galerie a kotevní nájemce (magnet) v podobě hypermarketu nebo většiho supermarketu (ICSC, 2012). Definice renomované poradenské společnosti Cushman \& Wakefield je obdobná a říká, že: nákupní centrum je centrálně rízené, účelově postavené 
maloobchodní zařizení, zahrnující jednotkové i společné prostory, s hrubou pronajímatelnou plochou větší než $5000 \mathrm{~m}^{2}$. Outletové prodejny a retail parky nejsou mezi nákupní centra zahrnovány (Cushman \& Wakefield, 2011).

Tab. 5.2: Mezinárodní standard pro jednotlivé typy evropských nákupních center

\begin{tabular}{|c|c|c|c|}
\hline $\begin{array}{l}\text { Maloobchodní } \\
\text { formáty }\end{array}$ & Typ zástavby & $\begin{array}{l}\text { Hrubá pronajímatelná } \\
\text { plocha (GLA) v m² }\end{array}$ & $\begin{array}{l}\text { Maloobchodní } \\
\text { formáty }\end{array}$ \\
\hline \multirow{5}{*}{ Tradiční } & Velmi velké NC & & 80000 a více \\
\hline & Velké NC & & $40000-79999$ \\
\hline & Střední NC & & $20000-39999$ \\
\hline & \multirow{2}{*}{ Malé NC } & Comparison-based & $5000-19999$ \\
\hline & & Convenience-based & $5000-19999$ \\
\hline \multirow{6}{*}{ Specializované } & \multirow{3}{*}{ Retail Park } & Velký & 20000 a více \\
\hline & & Střední & $10000-19999$ \\
\hline & & Malý & $5000-19999$ \\
\hline & Factory Outlet Center & & 5000 a více \\
\hline & \multirow{2}{*}{ Theme-oriented Center } & Leisure-based & 5000 a více \\
\hline & & Non-leisure-based & 5000 a více \\
\hline
\end{tabular}

Pozn.: NC = nákupní centrum

Zdroj: LAMBERT, Jean (2006): One Step Closer to a Pan-European Shopping Center Standard. International Council of Shopping Centres. Dostupné z WWW: <http://wWw.icsc. org/srch/lib/euro_standard_only.pdf>.

Základem členění nákupních center dle studie ICSC je prostorově-technické řešení a hrubá pronajímatelná plocha. Za tradiční model nákupního centra Ize považovat víceúčelový projekt koncepčně řešený jako uzavřená stavba, ale i stavba na volném prostranství, jenž může být dále členěn podle velikosti. Specializovaný model nákupního centra zahrnuje specifické účelové maloobchodní jednotky, které jsou postaveny typicky na otevřeném prostranství a mohou být opět členěny podle velikosti.

Comparison-based jsou centra, jejichž nájemníci jsou výhradně prodejci módy, obuvi, bytového zařízení, elektroniky, drogerie a parfumerie, hraček, luxusního a dárkového zboží apod. Jsou obvykle součástí větších maloobchodních oblastí (například městských center) a nemají tzv. magnet v podobě výrazného super- či hypermarketu ${ }^{18}$ ( $v$ ČR např. IGY Centrum České Budějovice, Varyáda v Karlových 
Varech). Jde o nákupní centra, kde má zákazník možnost provést srovnání (comparison) kvality a ceny a podle toho vybírat.

Convenience-based jsou centra zaměřená zejména na běžný spotřební sortiment, s dominantním magnetem (supermarket, hypermarket), kolem něhož se nacházejí menší obchodní jednotky jako květiny, potřeby pro zvířata, drogerie, ale i vybrané specializované obchody. Tento typ center je umistován na okraj měst nebo mimo město do suburbánní zóny. Jako př́klad malých center lze uvést EuroCenter v Hradci Králové nebo DBK Budějovická v Praze). V České republice nalezneme všechny velikostní typy nákupních center od velmi velkých až po malé.

Retail park je projektem zahrnujícím tři a více maloobchodních jednotek $v$ rámci jednoho objektu. Součástí objektu je parkoviště, jež je sdíleno všemi nájemci. Retail park mívá jednotný design vytvořený jediným developerem. ${ }^{19}$ Velkým retail parkem v ČR je např. Avion Shopping Park v Praze, středním Haná $\checkmark$ Olomouci a malým Retail park Most. Typem prodejního konceptu, jenž občas připomíná maloobchodní parky, je klastr (cluster). Jedná se o skupinu minimálně tří samostatně stojících jednotek vedle sebe, s vlastním vstupem a venkovní promenádou. Každá z nich může mít odlišného majitele. Retail parky se díky své cenové politice (zpravidla méně renomované značky a nižší ceny než v nákupních centrech) rozšiřují i do menších měst s 20-30 tis. obyvateli. Součástí bývají parkoviště, která jsou bud'to sdílená, nebo samostatná pro jednotlivé operátory. ${ }^{20}$

Factory outlet centrum je projekt s oddělenými maloobchodními jednotkami, kde prodejci nabízejí se slevami zejména značkové oděvy a obuv starších kolekcí. Díky velkým slevám a menší konkurenci mají obvykle větší spádové území než klasické nákupní komplexy. ${ }^{21} \mathrm{~V}$ České republice jsou zatím pouze dvě outletová centra, a to Freeport Hatě na Znojemsku a v Praze-Štěrboholích. Leisure-based centrum je většinou vybaveno multikinem, které zde představuje magnet, ale i jinými zařízeními (např. restaurace, bary, fitness centra, bowling). Non-leisurebased centrum je naopak zaměřeno na určitou specifickou oblast (móda, bytové vybavení) nebo cíleně na určitý typ zákazníků (např. obchody na letištích). Vzhledem k velikosti trhu se v českých podmínkách tyto poslední dva typy center prakticky nerozlišují.

V České republice provádí každoročně průzkum nákupních center společnost Incoma GfK a ta ke konci roku 2010 uváděla zhruba 300 nákupních center všech velikostí. $V$ tomto počtu jsou však zahrnuta také centra s menší pronajímatelnou

\footnotetext{
19 http://www.realit.cz/clanek/velky-boom-zazivaji-retail-parky

20 V praxi je však pro běžného zákazníka odlišení retail parku od nákupního centra značně obtižné a často i nemožné. 
plochou než 5 tis. $\mathrm{m}^{2}$, dále hypermarkety s malou obchodní pasáží a všechny tradiční obchodní domy. ${ }^{22}$ Vzhledem ke skutečnosti, že nalézt jednotná kritéria pro klasifikaci nákupních center je stále obtižné, budeme se metodicky držet členění ICSC $\mathrm{s}$ hraniční hodnotou 5 tis. $\mathrm{m}^{2}$ hrubé pronajímatelné plochy. Do námi zjištěného a analyzovaného souboru 75 nákupních center nebyly, $z$ hlediska metodické korektnosti, zařazeny ani zmíněné hypermarkety a obchodní domy.

Tab. 5.3: Členění nákupních center v České republice dle hrubé pronajímatelné plochy k roku 2012

\begin{tabular}{|l|c|c|}
\hline Velikostní typ & GLA v m $^{2}$ & Počet jednotek \\
\hline Velmi velká & více než 80 000 & 4 \\
\hline Velká & $40000-79999$ & 23 \\
\hline Střední & $20000-39999$ & 37 \\
\hline Malá & $5000-19999$ & 2 \\
\hline Outletová centra & více než 5 000 & 74 \\
\hline Celkem (bez outletů) & - & 23 \\
\hline
\end{tabular}

Zdroj: Centers DATA, 2010. Webové stránky jednotlivých center, tiskové zprávy, vlastní šetření.

Velikost nákupních center je určována např. prodejní plochou, v našem případě se přikláníme $k$ dostupnějšímu i mezinárodně srovnatelnějšímu ukazateli hrubé pronajímatelné plochy. Pořadí největších nákupních center v ČR uvádí následující tabulka. V návaznosti na definici ICSC Ize nákupní centra rozčlenit do kategorií: velmi velká, velká, střední a malá. Čtveřici velmi velkých nákupních center nad 80 tis. $\mathrm{m}^{2}$ nalezneme v Praze, Brně a Ostravě. Velkých center s GLA mezi 40-80 tis. $\mathrm{m}^{2}$ je $v$ ČR deset, většina $z$ nich v Praze. Nejčetnější zastoupení mají střední a malá nákupní centra. obchodních domů vybudovaných před rokem 1990. Proto nebyly do seznamu nákupních center tyto, dnes často fungující, obchodní domy zahrnuty. Výjimkou je např. nákupní centrum Forum Liberec, jež je funkčně i prostorově propojeno s původním obchodním domem, dnes My Tesco. 
Tab. 5.4: TOP 10 největších nákupních center v České republice k roku 2012

\begin{tabular}{|l|c|c|c|}
\hline Název & Lokalita & Rok otevření & GLA v $\mathbf{~}^{\mathbf{2}}$ \\
\hline Letňany & Praha & 1999 & 125000 \\
\hline Olympia Brno & Brno & 1999 & 110000 \\
\hline Nový Smíchov & Praha & 2001 & 85150 \\
\hline Avion Shopping Park & Ostrava & 2001 & 85100 \\
\hline Avion Shopping Park & Brno & 1998 & 60137 \\
\hline Centrum Chodov & Praha & 2005 & 55000 \\
\hline Metropole Zličín & Praha & 2002 & 55000 \\
\hline Centrum Černý Most & Praha & 1997 & 53320 \\
\hline Avion Shopping Park & Praha & 1998 & 52400 \\
\hline Galerie Harfa & Praha & 2010 & 49000 \\
\hline
\end{tabular}

Zdroj: Centers DATA, 2010. Webové stránky jednotlivých center, tiskové zprávy, vlastní šetření.

\subsection{Lokalizace nákupních center: Česká republika, Slovensko}

Důležitým aspektem nákupních center je jejich lokalizace, jelikož bývá často diskutována při územním plánování a musí podléhat regulacím a odpovídat také environmentálním hlediskům tak, aby nenarušovala životní prostředí (Koželouh, 2010). V zásadě Ize rozlišit tři možnosti lokalizace nákupního centra (Guy, 1998a): i) okraj centra města (edge-of-centre), ii) mimo centrum města (out-of-centre) a iii) mimo město (out-of-town). Při stavbě nového nákupního centra je třeba respektovat všechny aspekty, které může mít výstavba na území v jeho okolí. Největším konfliktem nové zástavby je především nahrazení do té doby zcela jinak využívaného půdního fondu. Dále jde o zásah do městské či príměstské kulturní krajiny, což s sebou může nést i negativní postoj dotčeného obyvatelstva.

Prostorové rozložení nákupních center poměrně věrně odráží postavení jednotlivých měst v hierarchii sídelního systému České republiky (jasná dominance Prahy, následovaná Brnem, Ostravou a dalšími velkými krajskými městy, přičemž jen minimum nákupních center se nachází mimo krajská města) a kupní sílu obyvatelstva v př́slušných regionech (např. centra v Mladé Boleslavi nebo i v Chebu - blízkost zákazníků z Německa). 


\section{Obr. 5.6: Nákupní centra v České republice (2012)}

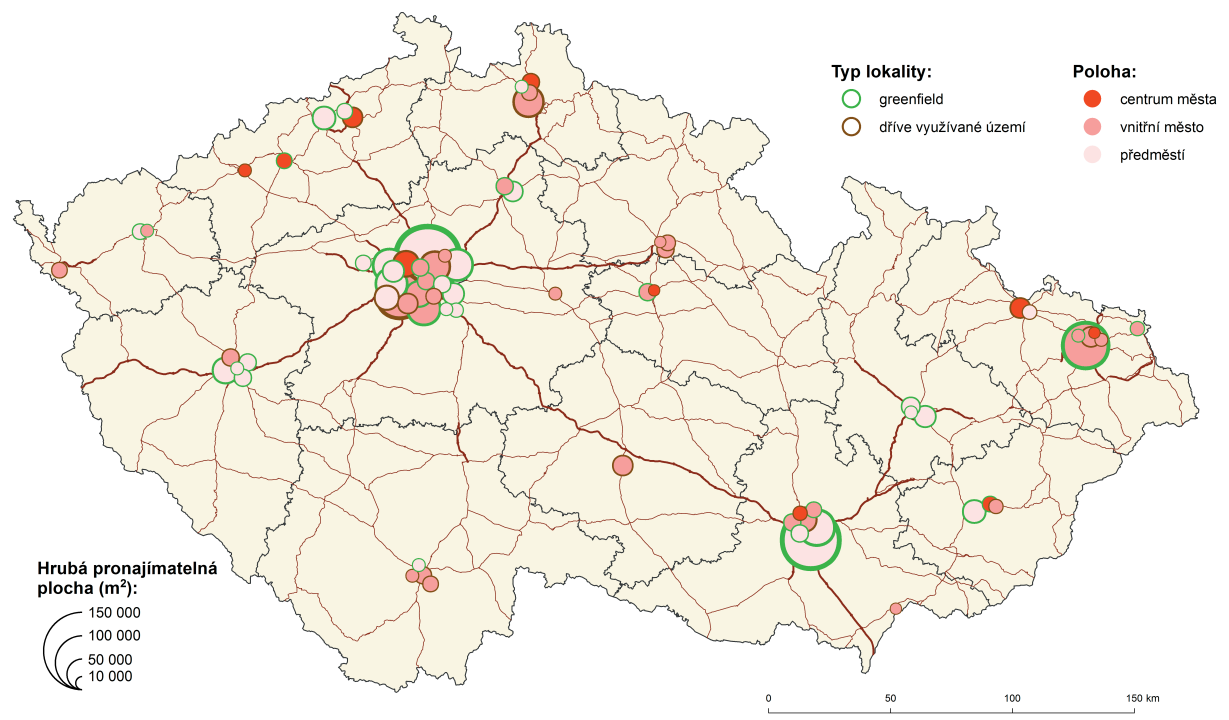

Zdroj: Centers DATA, 2010. Webové stránky jednotlivých center, tiskové zprávy, vlastní šetrení.

Především zpočátku developeři preferovali jednodušší cestu, kterou je výstavba na zelené louce - ze 75 nákupních center jich tímto způsobem vzniklo 42 a z toho 31 do roku 2005, většinou (2/3) v předměstských lokalitách. Teprve poté se pozornost developerů zaměřila i na vnitřní části měst a od roku 2006 jsou dvě ze tří nákupních center otevírány na dříve zastavěných územích. Ovšem centra postavená na zelené louce zůstávají významnější z hlediska nabídky ploch (65 \% celkového objemu pronajímatelné plochy), a to především ta, jež jsou lokalizovaná v suburbánní zóně.

Ve srovnání s Českou republikou je u vývoje výstavby nákupních center na Slovensku možné pozorovat určité zpoždění. První nákupní centrum bylo otevřeno v Bratislavě (Polus City) až v roce 2000, přičemž dynamika výstavby byla $\checkmark$ dalších letech velmi nízká (viz také obrázek 5.7). Vrcholem stavebního a investičního boomu byl na Slovensku rok 2010, což bylo o dva roky později než v ČR. Následující propad byl ovšem v obou zemích obdobně strmý.

Regionální rozmístění nákupních center na Slovensku je podobně jako v ČR také značně nerovnoměrné. $V$ Bratislavě a dalších čtyřech krajích je koncentrována většina center; slovenské hlavní město ovšem nemá tak dominantní pozici jako Praha. Pokud se podíváme na další podobnosti či rozdíly mezi oběma země$\mathrm{mi}$, tak na Slovensku obdobně věnovali developeři zpočátku pozornost výstavbě 
nákupních center na zelené louce. Ze 44 center jich tímto způsobem vznikla polovina a z toho 16 do roku 2007 (pouze 8 na dřive jinak využívaném území); až na výjimky to bylo $v$ předměstských lokalitách.

Od roku 2008 se pozornost developerů více zaměřila také na vnitřní části měst a do současnosti byly téměř $2 / 3$ nákupních center postaveny na dřive zastavěných územích. Opět podobně jako v ČR (ovšem méně výrazně) zůstávají centra postavená na zelené louce významnější z hlediska nabídky ploch (56 \% celkového objemu pronajímatelné plochy), a to především ta, jež jsou lokalizovaná v suburbánních zónách. V ČR nemají kotevní hypermarket nebo supermarket pouze dvě nákupní centra, na Slovensku plných osm - zde jsou nákupní centra častěji součástí retail parku nebo smíšené nákupně-administrativní zóny, kde se nachází samostatná velkoplošná jednotka s převahou potravinářského zboží.

\section{Obr. 5.7: Vývoj výstavby nákupních center na Slovensku v letech 2000-2012}

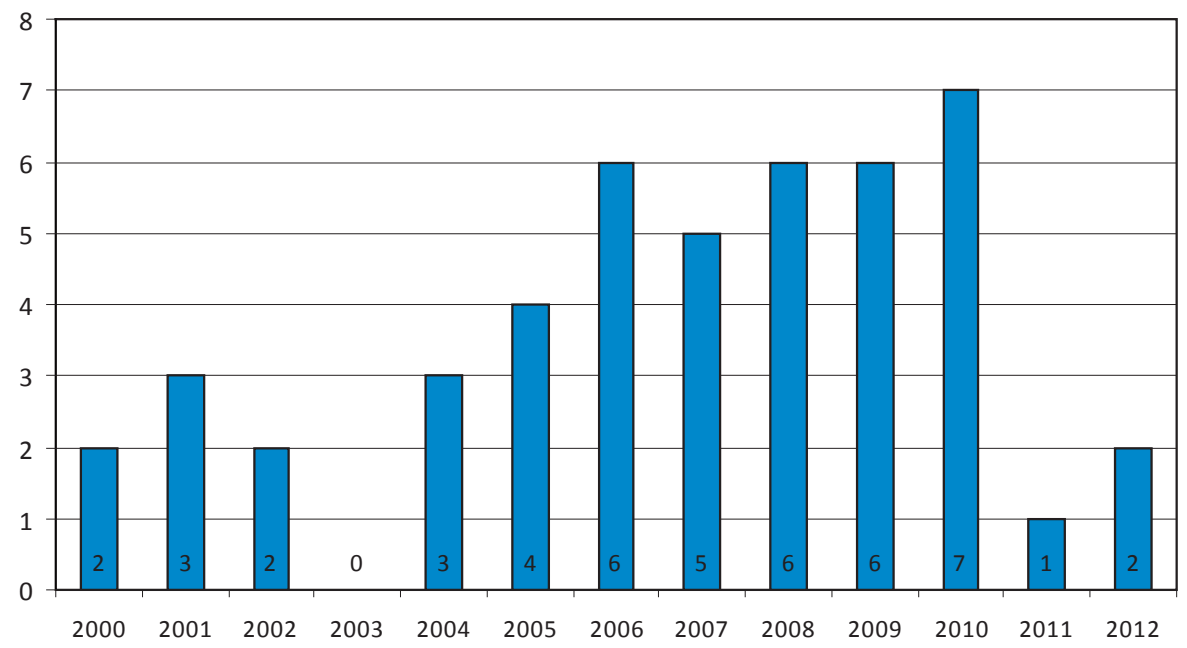

Zdroj: Centers DATA, 2010. Webové stránky jednotlivých center, tiskové zprávy, vlastní šetrení. 


\section{Obr. 5.8: Regionální rozmístění nákupních center na Slovensku}

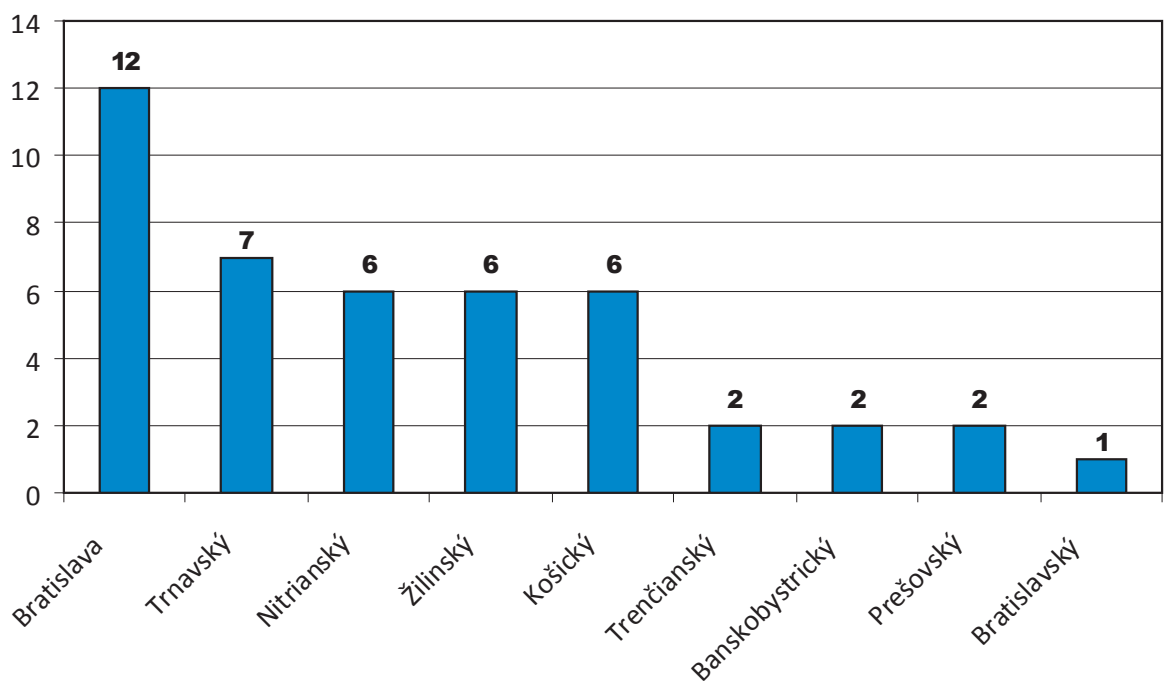

Zdroj: Centers DATA, 2010. Webové stránky jednotlivých center, tiskové zprávy, vlastní šetření.

\section{Obr. 5.9: Nákupní centra na Slovensku (2012)}

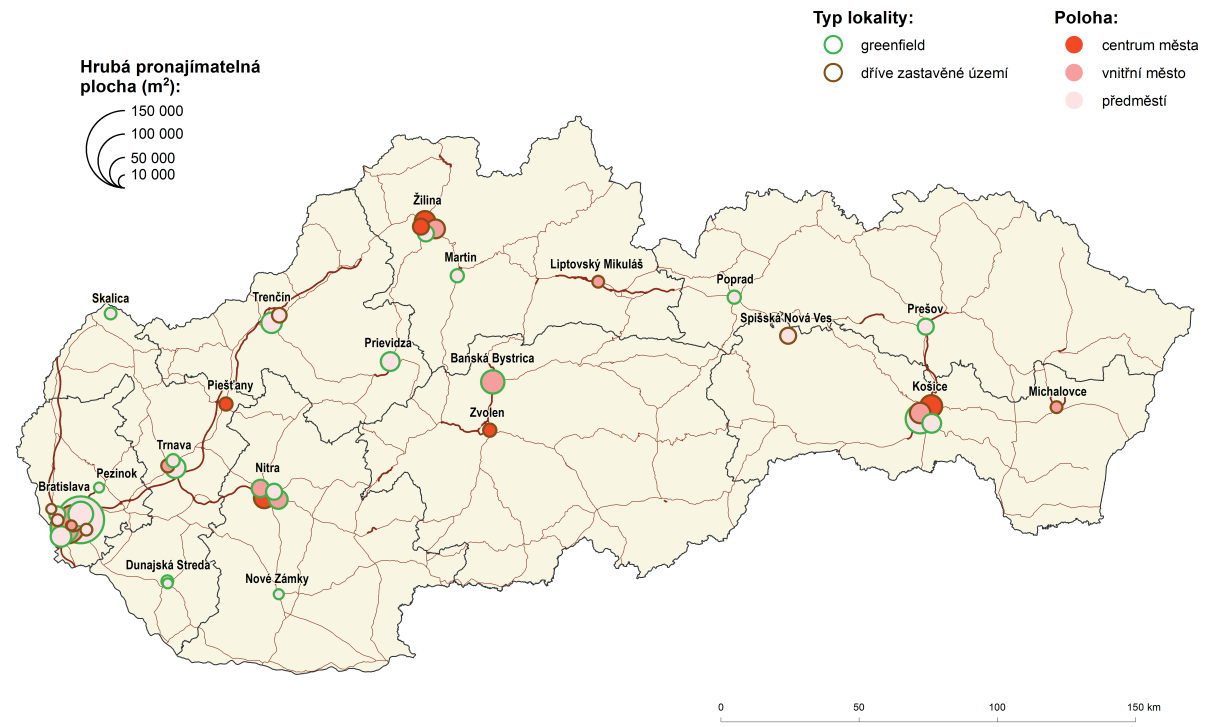

Zdroj: Centers DATA, 2010. Webové stránky jednotlivých center, tiskové zprávy, vlastní šetření. 
Průměrná velikost nákupního centra v České republice je 27 tis. $\mathrm{m}^{2}$, na Slovensku 21 tis. $\mathrm{m}^{2}$. Největší hrubou pronajímatelnou plochu na obyvatele nalezneme v Liberci $\left(924 \mathrm{~m}^{2}\right)$, resp. v Nitře $\left(1135 \mathrm{~m}^{2}\right)$, jak dokládá také tabulka 5.5. Obě hlavní města jsou shodně na třetím místě.

Tab. 5.5: Hrubá pronajímatelná plocha v nákupních centrech na obyvatele ve vybraných městech

\begin{tabular}{|l|l|}
\hline Česká republika & Slovensko \\
\hline 1. Liberec $\left(924 \mathrm{~m}^{2}\right)$ & 1. Nitra $\left(1135 \mathrm{~m}^{2}\right)$ \\
\hline 2. Brno $\left(730 \mathrm{~m}^{2}\right)$ & 2. Žilina $\left(1015 \mathrm{~m}^{2}\right)$ \\
\hline 3. Praha $\left(625 \mathrm{~m}^{2}\right)$ & 3. Bratislava $\left(816 \mathrm{~m}^{2}\right)$ \\
\hline 4. Ostrava $\left(614 \mathrm{~m}^{2}\right)$ & 4. Košice $\left(543 \mathrm{~m}^{2}\right)$ \\
\hline
\end{tabular}

Zdroj: Centers DATA, 2010. Webové stránky jednotlivých center, tiskové zprávy, vlastní šetření.

Kde lze aktuálně hledat trendy pro nejbližší budoucnost? V ČR i na Slovensku aktuálně tento trh spíše stagnuje, zastavila se či odložila výstavba některých dlouhodoběji plánovaných objektů. V ČR byla v roce 2012 otevřena pouze dvě nákupní centra (Nová Karolina v Ostravě s 58 tis. $\mathrm{m}^{2}$ a Breda \& Einstein v Opavě s 26 tis. $\mathrm{m}^{2}$ ), dostavuje se Nová Šantovka v Olomouci. Některá úspěšná centra se budou remodelovat nebo rozšiřovat (Ostrava, Hradec Králové, Olomouc, Zlín). Předpokládá se výstavba 1-2 center ročně, gigant typu Nová Karolina bude spíše výjimečný.

Na Slovensku je situace obdobná, k nově otevřeným centrům v Trnavě a Zvolenu má přibýt také Central v Bratislavě (35 tis. $\left.\mathrm{m}^{2}\right)$ a čeká se jeho vliv na ostatní nákupní centra v hlavním městě Slovenska. Rozšiřuje se centrum Madaras ve Spišské Nové Vsi a Avion v Bratislavě. Některá další města mají do budoucna potenciál absorbovat nové nákupní plochy - Poprad, Trnava, Levice, Banská Bystrica, Prešov, Košice a další, což v príípadě tolika měst v ČR říci nelze.

\subsection{Počínající krize nákupních center?}

Jak již bylo výše naznačeno, přestože určitý prostor pro výstavbu, rozšiřování či remodelaci nákupních center v České republice ještě existuje, nekoordinovaný boom s velkou pravděpodobností v blízké době nenastane. Naopak dnes nalezneme v ČR nákupní centra, která mají problémy a bojují s krizí. Ve srovnání s prostorem západní Evropy to není nic neobvyklého (Cummins, Macintyre, 1999; Severin et al., 2001; Crosby, 2005). První nákupní centrum v ČR bylo zavřeno již v roce 2009 (Stodůlky v Praze), Galerii Nové Butovice v Praze převzala banka 
a Olomouc City bylo prodáno v nedobrovolné dražbě. Příčin těchto nepřehlédnutelných problémů je celá řada. $V$ roce 2012 vzrostla snížená sazba DPH z 10 na $14 \%$, což se mimo jiné dotklo potravin, nealkoholických nápojů, knih, léků a dalšího sortimentu, který nákupní centra nabízejí. Spolu se společensky stále silně vnímanou hospodářskou krizí to odrazuje zákazníky od objemu nákupů, na které byli majitelé center zvyklí.

Problémy nákupního centra však nejsou většinou otázkou jednoho roku, ale tří a více let. Jeden rok v současné době již k zavedení nového centra nestačí. Vše je dáno fungováním nákupního centra. Vstupní investice $v$ řádu mnoha set milionů až miliard Kč leží na bedrech majitele $v$ podobě dluhu u banky, příp. u mateřské společnosti. Dluh je následně splácen z tržeb za pronájem prodejních ploch obchodníkům, kteří se po rozhodnutí vstoupit do daného centra snaží přilákat zákazníky, aby mohli nájem platit. Aby tento vytvořený kruh fungoval, je zapotřebí vhodně seskládat celou mozaiku existence nákupního centra.

Prioritní je výběr místa, protože lidé v České republice nejsou př́liš ochotni chodit nakupovat jinam, než jsou zvyklí. Pokud je centrum postaveno mimo pravidelné cesty potenciálních zákazníků, je třeba je dostatečně motivovat ke změně nákupního chování a spádu. Ale ani motivace v podobě různých doplňkových atrakcí či služeb (kluziště, dinopark apod.) nemusí znamenat úspěch. Velice důležitá je lokalizace s prímým napojením na MHD či v blízkosti velkého dopravního uzlu (viz dále). Dále je to vhodná skladba nájemců. Zejména renomované značky v oblasti módy a módních doplňků (C \& A, H \& M, Marks \& Spencer, Zara a další) jsou důležitým indikátorem úspěšnosti centra. $V$ zavedených centrech není problém tyto nájemce udržet, do těch méně úspěšných se jim ovšem nechce. Majitelé jsou potom nuceni se podílet na riziku velkých kotevních nájemců a udržet je v centru za cenu pobídek typu „čistě obratové nájemné“, kdy obchodník platí jen určité procento $z$ tržby, a nikoliv fixní nájemné, nebo vlastník zainventuje část vybavení prodejny.

Jak se tedy takové neúspěšné nákupní centrum vlastně pozná? Nepřehlédnutelná jsou poloprázdná parkoviště u center v periferní poloze. Některá nákupní centra v hustější zástavbě ovšem mohou sloužit jako „parkoviště“ pro zaměstnance blízkých kancelárí nebo návštěvníky různých úřadů a institucí zejména pokud je parkoviště v pracovní dny po určitou dobu zdarma. Pokud pomineme uvnitř nezaplněné prostory, většinou překryté barevnými tapetami s reklamními motivy, nabízí se další „indicie“. Podle Zdeňka Havelky (ředitel realitní skupiny $\mathrm{CPI})^{23}$ začne centrum postupně šednout, zavírají se některé výlohy a stahují se vývěsky typu „....zde pro Vás připravujeme nový obchod...", resp. 
„....otevíráme již..." a nakonec do centra přijdou ordinace, nábytkářská studia a různé poradenské firmy. Tyto firmy platí nižší nájem, renomované značky často neprodlouží smlouvy (nejčastěji pětileté).

Obr. 5.10: Ukázky uzavřených a připravovaných obchodů

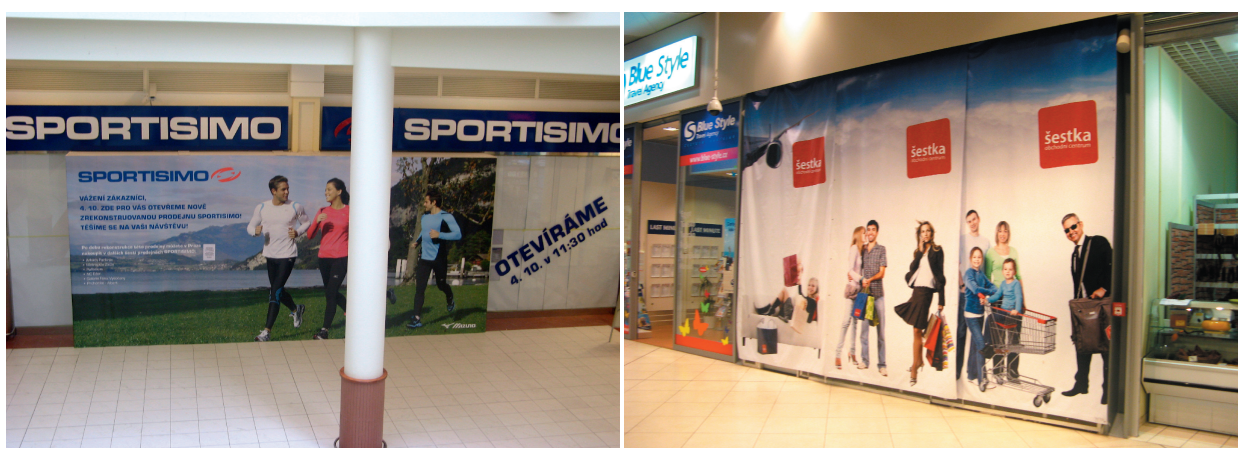

Foto: Josef Kunc

Dalším příladem náhrady uvolněných prostor po původních nájemcích jsou různé formy společenských kulturních a zábavních aktivit. Typická jsou tzv. „family centra", což nejsou prostory, kde mohou rodiče za úplatu předat dítě odbornému personálu na hlídání, ale místa pro divadélka, dílničky a další nárazové akce pro děti. K vidění jsou také galerie a výstavní prostory, kosmetické a ozdravné salony, prodejci nábytku a kuchyňského zboží. Častým náhradním programem bývá zábava ve formě bowlingu, restaurace a heren s ruletou, což jsou ideální aktivity k výplni velkých ploch. Typickou indicií je také obchod s erotickým zbožím.

Obr. 5.11: Ukázky náhradních řešení uvolněných prostor v nákupních centrech
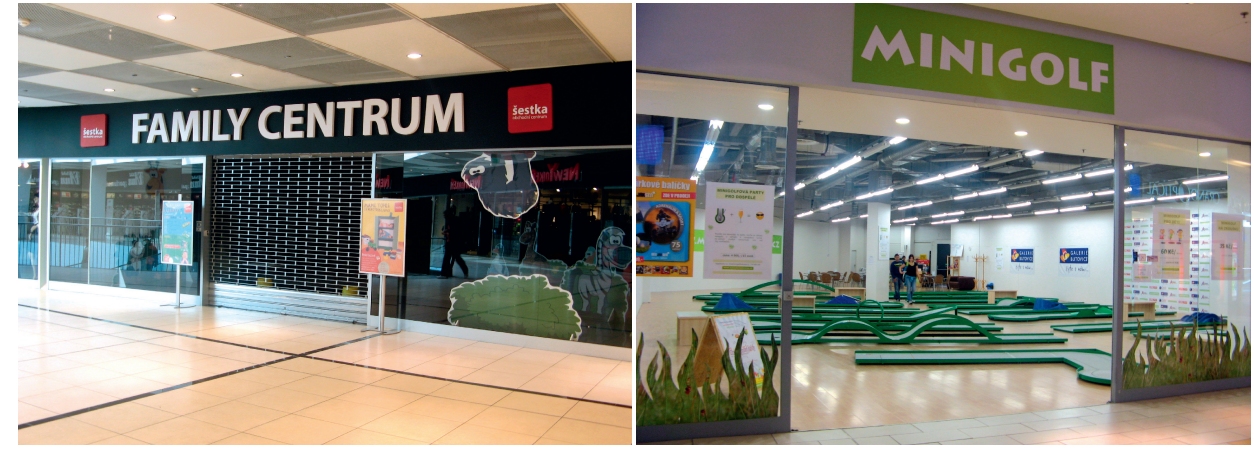

Foto: Josef Kunc 
Pokud se blíže podíváme na některá nákupní centra v Praze, kde je těch problematických nejvíce, dojdeme $k$ určitým skutečnostem, jež mohou jejich potiže indikovat. Nejčastěji se hovoří o nákupním centru Stodůlky (jediné skutečně zavřené centrum v ČR), Nové Butovice, Novodvorská Plaza a Šestka.

Tab. 5.6: Vybrané charakteristiky problematických nákupních center

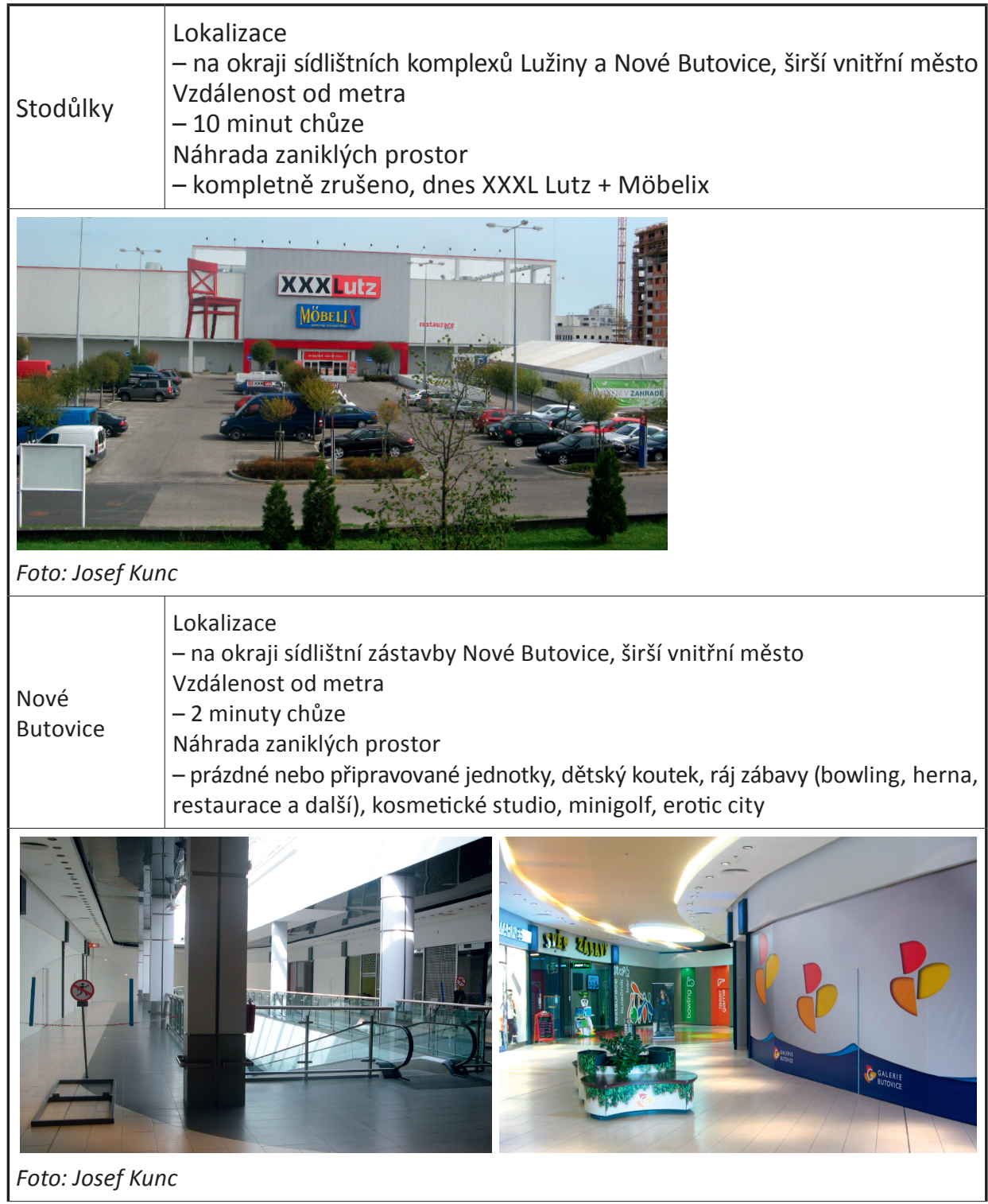




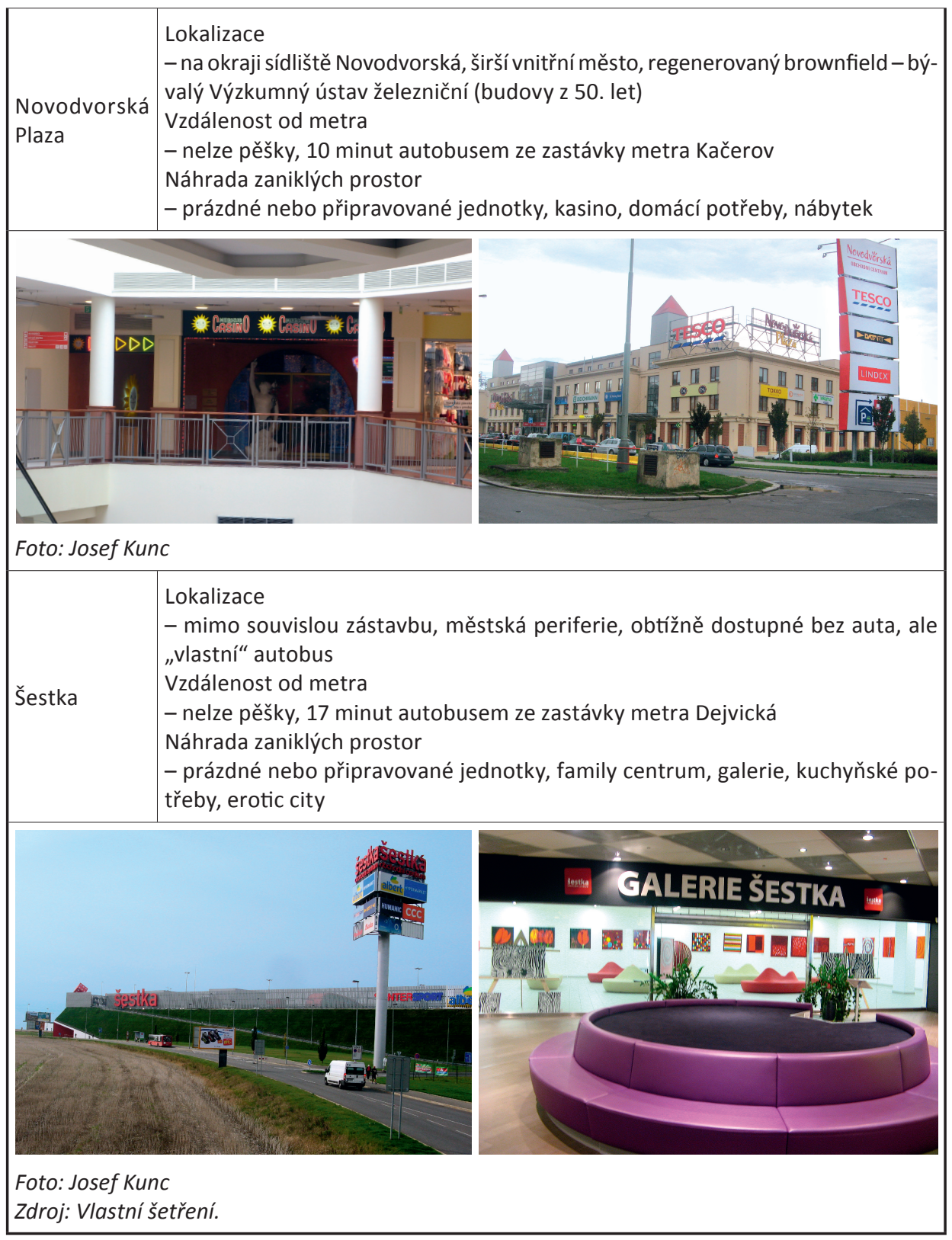




\subsection{Modelový př́klad města Brna}

V kontextu metodických definic ICSC a společnosti Cushman \& Wakefield a s přihlédnutím k lokálním podmínkám jsme v Brně, jako modelovém městě, vymezili devět nákupních center. Parametry hrubé pronajímatelné plochy vyšší než $5000 \mathrm{~m}^{2}$ nesplňuje pouze centrum Omega. Výjimkou je také hypermarket Globus, který je s hobbymarkety Baumarkt a Bauhaus spíše retail parkem, ale prakticky plní funkci nákupního centra a jeho spádové území (pokud bereme v úvahu pouze maloobchod, ne zábavu a volný čas) je reálně srovnatelné s Olympií na jihu města. Obchodní a multifunkční domy, galerie a ostatní hypermarkety s pasáží nebyly do sledovaného vzorku zařazeny. Na obrázku 5.12 jsou v morfogenetických zónách města Brna ${ }^{24}$ lokalizována nákupní centra, $\mathrm{k}$ nimž se také váže další text. Na konkrétním příkladu města Brna tak lze poukázat na funkční a prostorové aspekty lokalizace nákupních center, jež budou koncepčně obdobné, resp. typické i v dalších městech podobné velikosti.

Tab. 5.7: Základní údaje o nákupních centrech v Brně

\begin{tabular}{|l|c|c|c|c|c|}
\hline Název & $\begin{array}{c}\text { Rok } \\
\text { otevření }\end{array}$ & $\begin{array}{c}\text { Lokalizace } \\
\text { v rámci města }\end{array}$ & $\begin{array}{c}\text { GLA } \\
\text { v m² }\end{array}$ & $\begin{array}{c}\text { Počet } \\
\text { nájemních } \\
\text { jednotek }\end{array}$ & $\begin{array}{c}\text { Počet } \\
\text { parkova- } \\
\text { cích míst }\end{array}$ \\
\hline Globus Hypermarket & 1996 & příměstská zóna & 13500 & 15 & 1100 \\
\hline Avion Shopping Park & 1998 & příměstská zóna & 60100 & 58 & 2550 \\
\hline Olympia & 1999 & příměstská zóna & 111000 & 220 & 4030 \\
\hline Velký Špalíček & 2001 & historické jádro & 12800 & 43 & 80 \\
\hline Futurum & 2001 & příměstská zóna & 32300 & 91 & 1500 \\
\hline Královo Pole & 2004 & širší vnitřní město & 21400 & 81 & 860 \\
\hline Vaňkovka Gallery & 2005 & vnitřní město & 37000 & 130 & 1000 \\
\hline Omega & 2006 & historické jádro & 3500 & 30 & 0 \\
\hline Campus Square & 2008 & panelová sídliště & 22000 & 55 & 620 \\
\hline
\end{tabular}

Zdroj: Centers DATA, 2010. Vlastní šetření.

- Centrum města - tradiční obchodní, obslužná i administrativní část města s nákupními centry vsazenými do historické zástavby (např. Velký Špalíček a Omega v historickém jádru). 


\section{Obr. 5.12: Lokalizace nákupních center v Brně}

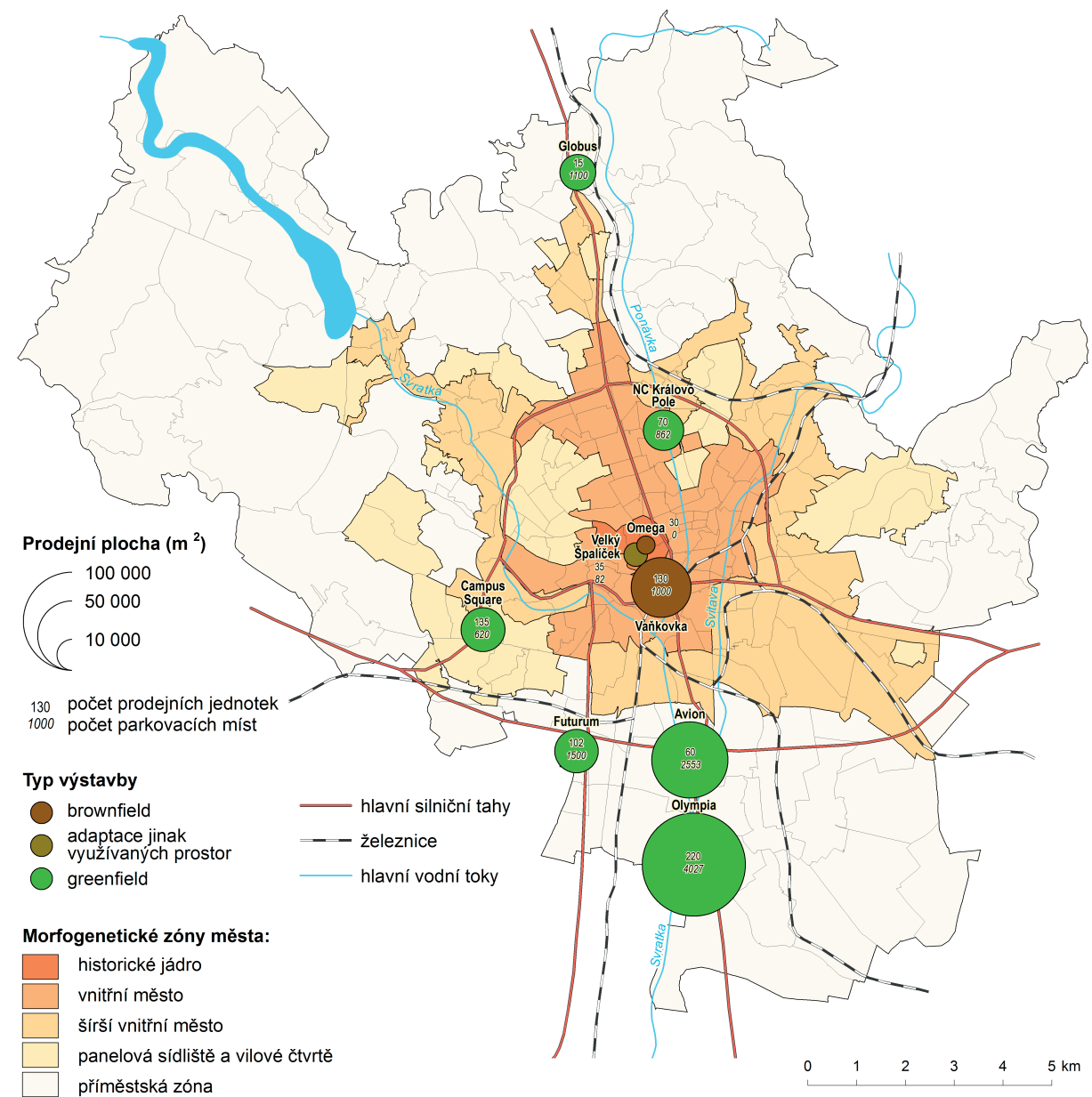

Zdroj: Vlastní zpracování. Morfogenetické zóny upraveny dle Mulíček (2007). 
Obr. 5.13: Nákupní centrum Omega v Brně na náměstí Svobody - historické jádro

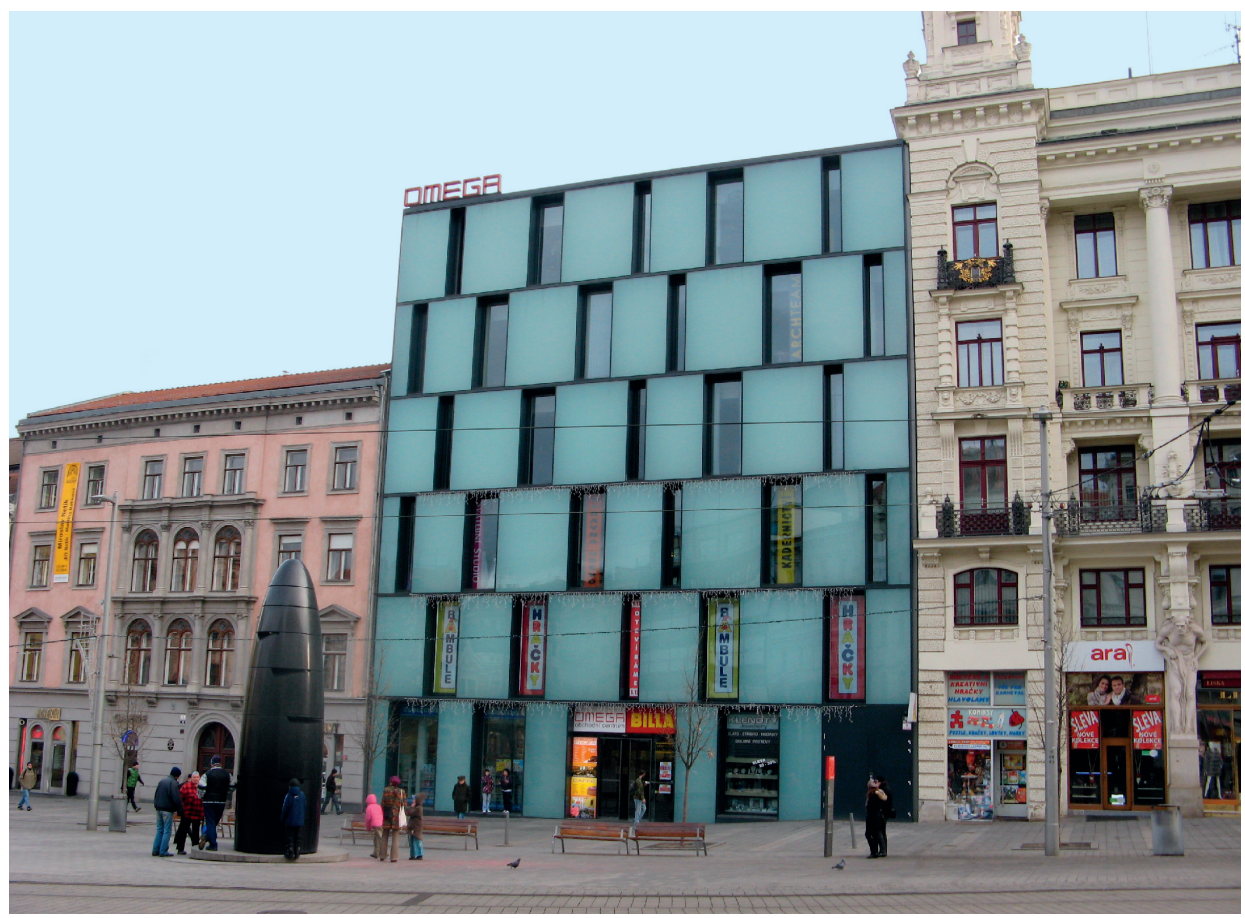

Foto: Josef Kunc

- Okraj městského centra - část města již také s jinými než maloobchodními plochami (např. průmysl, administrativa, vzdělávací instituce apod.), centrum je velmi dobře dostupné (např. Galerie Vaňkovka volně navazující na historické jádro z jihu).

- Širší vnitřní město - městské čtvrtě navazující na historické centrum, často s významnou rezidenční, ale i průmyslově-administrativní funkcí, kde je výstavba nákupních center již lépe realizovatelná na volnějších plochách (např. Nákupní centrum Královo Pole s hypermarketem Tesco severně od centra).

- Příměstská oblast - nákupní centra vsazená většinou do okrajových sídlišt' doplňují dřívější občanskou vybavenost (např. Campus Square na JZ Brna, rozhraní sídlišt' Bohunice - Nový/Starý Lískovec). 
Obr. 5.14: Nákupní centrum Královo Pole - širší vnitřní město a Campus Square - příměstská oblast

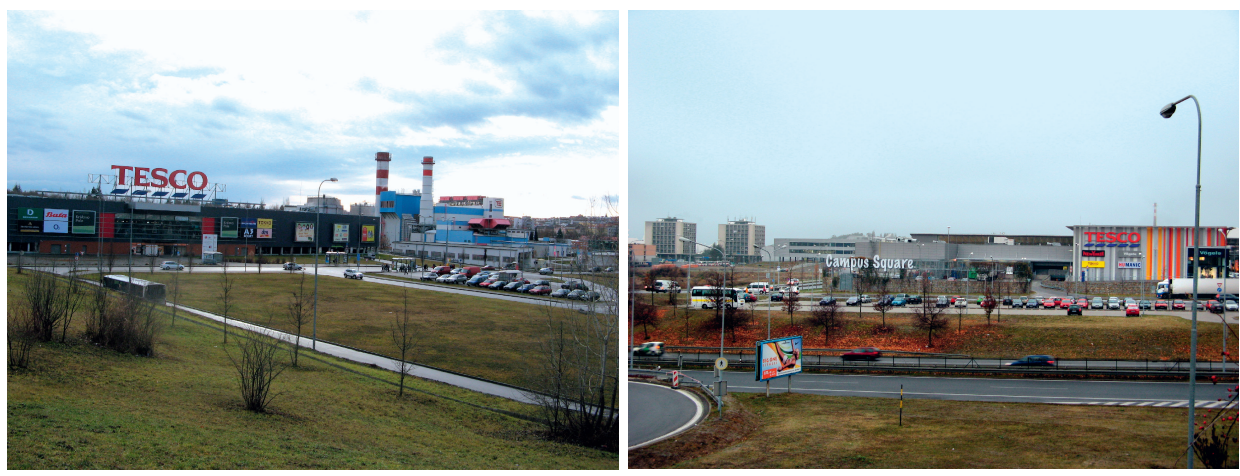

Pozn.: Campus Square je z územního hlediska součástí nového univerzitního kampusu Masarykovy univerzity. Uspořádáním maloobchodních jednotek je reálně moderní kombinací nákupního centra a retail parku.

Foto: Josef Kunc

- Suburbánní oblast - výstavba nákupních center je minimálně omezována původní zástavbou, většinou na hranici či mimo administrativní hranice města ve volné krajině nebo v původní vesnické zástavbě s nižším maloobchodním standardem (např. Nákupní centrum Olympia Brno na katastru města Modřice, jižně od města, nebo hypermarket Globus na severním okraji města na katastru městské části Brno-Ivanovice).

Obr. 5.15: Nákupní centrum Olympia Brno v Modřicích a hypermarket Globus v Ivanovicích - vnější suburbánní oblast
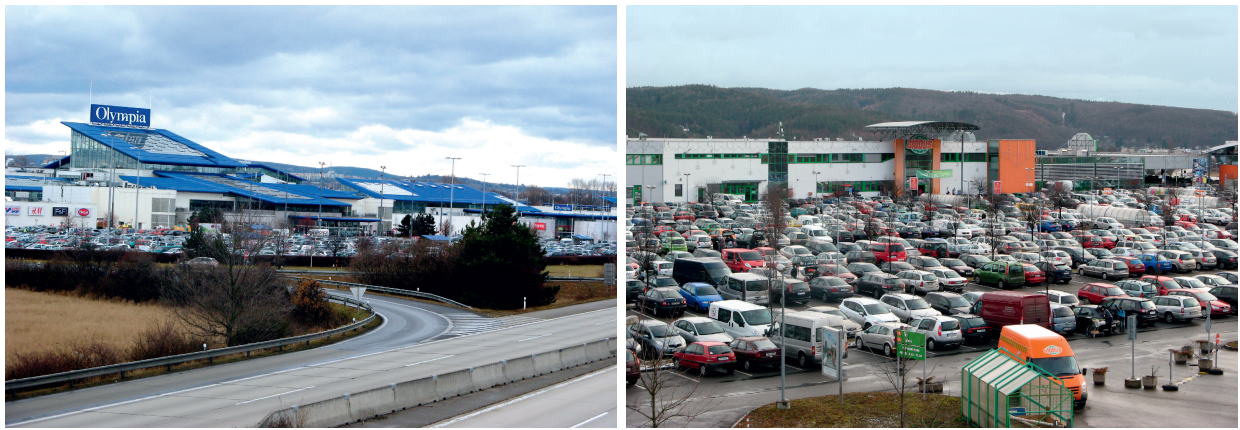

Foto: Josef Kunc 
V centru města a na okraji městského jádra Ize nalézt nejčastěji nákupní centra vsazená do původní husté zástavby, kde dochází k propojení historických prvků s moderní architekturou, ve více či méně zdařilé podobě (např. kontroverzní Palladium Praha, Velký Špalíček v Brně, Forum v Ústí nad Labem, Zlaté Jablko ve Zlíně apod. - někdy se v negativním smyslu hovoří o tzv. „fasádismu“). Zřídka se může jednat také o zcela novou stavbu bez provázanosti s původními prvky, jako je tomu v prípadě brněnského obchodního centra Omega na náměstí Svobody. Centrum bylo vybudováno v domovní proluce a odborníky i veřejností je vnímáno spíše pozitivně.

Výstavba a další rozšiřování center v rámci vnitřních městských struktur jsou vždy limitovány kulturně-historickou hodnotou původní zástavby. Jedná se typicky o vícepodlažní objekty s nižší celkovou pronajímatelnou plochou, kde často neIze umístit jako magnet velkoplošnou prodejnu typu hypermarket. Magnetem se ovšem může stát např. multikino, které spolu s maloobchodními a obslužnými jednotkami přispívá k oživení historických městských jader. Ve specifických případech (u nás např. Ostrava) může město i v centru či jeho blízkosti disponovat dostatečnou plochou pro výstavbu velkého nákupního centra v poloze označované jako "in town" nebo „inner-city". Příkladem může být WestQuay Shopping Centre $\left(75000 \mathrm{~m}^{2}\right)$ v Southamptonu. Výstavba centra byla důležitou součástí regenerační strategie města, pro kterou se vzhledem k zásadní roli nákupního centra užívá označení „retail-led urban regeneration“, maloobchodem stimulovaná/ /tažená obnova města (Lowe, 2005).

Vzhledem $\mathrm{k}$ dopravním omezením $v$ centrech měst je nejčastějším a přirozeným způsobem dopravy chůze. Za určitý problém může být považován nedostatek parkovacích míst $v$ zázemí centra, což je zejména $v$ rámci pěších zón v historických jádrech pochopitelné, resp. kompenzované polohou a docházkovou vzdáleností $k$ veřejné dopravě či odstavným parkovištím.

Dnes již ne zcela ojedinělou formou výstavby nákupních center jsou revitalizace starých průmyslových objektů (většinou na okraji centra nebo v širším vnitřním městě) s využitím původních a někdy i architektonicky cenných objektů. Zdaleka přitom nemusí jít vždy jen o obchodní či komerční plochy, nicméně jak poukazuje Kok (2007), maloobchod je v těchto př́padech spolehlivým a důležitým zdrojem príjmů a stává se tak nepostradatelným, resp. klíčovým faktorem ovlivňujícím proveditelnost celého záměru. Výstavba je často omezena okolní zástavbou či dopravní infrastrukturou, parkovací místa bývají zpravidla v podzemí nebo na střeše. Příklady budiž patrně nejznámější nákupní centra tohoto typu u nás - Nový Smíchov v Praze ${ }^{25}$ a Galerie Vaňkovka v Brně. V obou prípadech 
došlo k vylepšení sociálního, ekonomického, ale i urbanistického prostředí dříve nepřitažlivé průmyslové části města. Vzhledem $\mathrm{k}$ exponované poloze $\mathrm{v}$ blízkosti centra se Nový Smíchov i Vaňkovka staly vyhledávanými pulzujícími organismy v každodenním rytmu města.

Obr. 5.16: Nákupní centrum Nový Smíchov v Praze a Galerie Vaňkovka v Brně
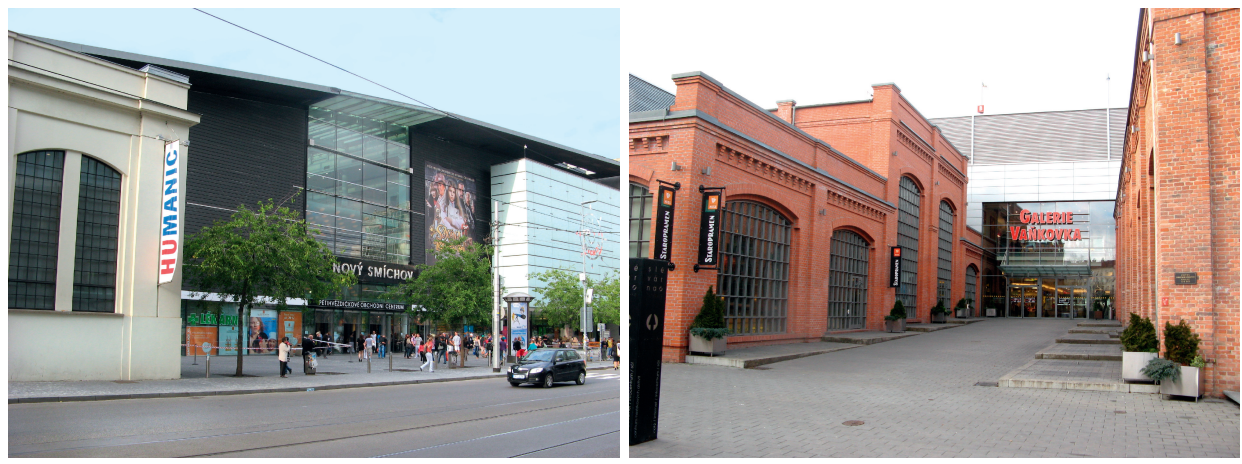

Pozn.: V popredí levého snímku je vidět část pưvodní budovy Ringhofferových závodů, později Tatry Smíchov. Na pravém snímku restaurovaná část původní slévárny a strojírny Friedrich Wannieck, později Zetor Brno.

Foto: Josef Kunc

Mimo střed města a jeho blízký okraj jsou možnosti prostorového rozmachu větší, centra vznikají přestavbou bývalých objektů občanské vybavenosti, ale i na volných plochách v sídlištních komplexech nebo po asanaci výrobních prostor. Součástí nákupních center bývá zpravidla hypermarket, hobby market, restaurace a zařízení služeb (např. Nákupní centrum Arkády Pankrác v Praze, Královo Pole v Brně, Nisa centrum v Liberci či Futurum v Ostravě). Na předměstích, resp. mimo samotné město pak vznikají obři projekty s rozsáhlými velkoplošnými objekty a úrovňovými parkovišti na volné ploše pro tisíce vozidel. Magnetem nemusí být vždy hypermarket $s$ prevahou potravinářského zboží, ale i jiný subjekt (typicky IKEA). Součástí mohou být a často bývají multikina, restaurace a občerstvení typu fast food, různá sportoviště, odpočinkové plochy a další zařízení služeb a volného času, ale i hobby markety a retail parky (např. nákupní centra Černý Most v Praze, Olympia v Modřicích u Brna, Haná v Olomouci, Géčko $v$ Liberci a mnoho dalších).

Nelze zcela popř́t, že výstavbou velkých nákupních center mimo urbanizované prostory se zvýší možnosti nákupů a trávení volného času nejen obyvatel samotného města, ale i z venkovských obcí v zázemí. Na druhé straně znamená 
tato výstavba značný zásah do kulturní krajiny a kvality života obyvatel dotčeného území (nová technická a dopravní infrastruktura, vznik nových linek MHD, zvýšení intenzity automobilové dopravy se všemi neduhy, zábor kvalitní půdy a další). $V$ tomto ohledu je na místě poznamenat, že $v$ mnoha západoevropských zemích již od 60. let existovala snaha výstavbu tohoto typu center nějakým způsobem regulovat, která postupně sílila s tím, jak se začala zřetelněji projevovat jejich hlavní negativa spojená s nárůstem individuální automobilové dopravy a oslabením či úpadkem tradičních nákupních míst v centrech měst (např. Guy, 1998b; nebo Poole et al., 2002). Oproti tomu tuzemští autoři (Spilková, 2010; Spilková, Perlín, 2010) opakovaně poukazují, že ačkoliv už i některé bývalé země východního bloku podobná opatření príijaly, v ČR dosud absentuje jednotný a efektivní nástroj či opatření pro regulaci velkoplošných maloobchodních zařízení mimo zastavěná území (resp. regulaci velkoplošných maloobchodních zařízení vůbec).

Na druhou stranu, výstavba nákupních center v rámci zastavěných rezidenčních prostor může přispět, a v řadě případů se tak stalo, k oživení historických jader a navazujících čtvrtí, jež ztrácejí své obchodní a obslužné funkce právě na úkor obřích center budovaných na zelené louce na okraji měst. Příspěvek městotvorné funkci spojený s přirozenou dojižd'kou či docházkou za obchodem a službami do vnitřního města zde není vůbec zanedbatelný.

\subsection{Shrnutí}

V roce 2012 dvě nově otevřená nákupní centra s více než 5 tis. $\mathrm{m}^{2}$ prodejní plochy v Ostravě a Opavě a od roku 2008 trvající propad výstavby nových objektů signalizuje, že v České republice skončila hlavní vlna expanze. Podle plánu bylo také rozšířeno Nákupní centrum Futurum v Hradci Králové. Přesto je vývoj $\checkmark$ roce 2012 možno brát jako mírné oživení po nulovém stavu v roce předchozím, kdy nebylo v ČR otevřeno žádné nákupní centrum. V roce 2013 bude dokončena Galerie Šantovka v Olomouci, plán na rozšíření existuje v př́padě pražských center Chodov a Metropole Zličín, u brněnské Vaňkovky a jiných. Na další roky je v plánu několik velkých projektů, zejména v Praze, většinou ovšem v kombinaci nákupní zóny, bydlení a administrativy.

Na rozdíl od aktuální slabší výstavby nákupních center jsou pro investory velmi velkým lákadlem retailové nemovitosti. Podle informací společnosti Cushman \& Wakefield a dalších zdrojů nakoupili investoři v roce 2011 na tuzemském trhu maloobchodní nemovitosti za 28,4 mld. Kč, což je téměř sedminásobný růst oproti roku 2010. V České republice byl zájem investorů o dobře fungující nákupní střediska velice silný v průběhu celého roku. Transakce byly uzavírány jak v Praze, tak i v dalších městech. Prodány byly například Palác Flóra v Praze, brněnská 
Olympia, Forum Ústí nad Labem, Forum Nová Karolina v Ostravě a další menší regionální centra. Rok 2011 byl oproti předchozím třem rokům v ČR i celé Evropě na trhu maloobchodních nemovitostí rokem oživení.

Kam tedy budou aktivity investorů a majitelů, co se týče nákupních center, $v$ příštích letech směřovat? $\vee$ prvé řadě do rozšíření či modernizace starších center ve velkých městech, a to hovoříme o objektech starých 6-10 let. Zavedená velká centra si modernizací (remodelingem) budou snažit udržet pozici na domácím trhu. $V$ současné konkurenci to ovšem nemusí stačit, dủležitá je řada dalších aspektů. Jedním ze zásadních je atraktivní lokalita spojená s dobrou dopravní dostupností. Zákazníci vyhledávají pohodlný př́ijezd na neplacené kapacitní parkoviště (např. Europark Štěrboholy a Černý Most v Praze či Olympia v Brně), př́p. kratší docházkovou vzdálenost od terminálů MHD (typicky Metropole Zličín a Centrum Chodov v Praze či Galerie Vaňkovka v Brně). Na druhé straně nemá zcela ideální dostupnost Palladium v centru Prahy, kde sice kolem projdou tisíce turistů denně, ale domácího zákazníka může odrazovat přehuštěný provoz a placené parkoviště.

Dalším faktorem úspěchu obchodního centra je profilace, resp. vhodná skladba nájemců. Již i na tuzemském trhu se etablovaly některé značky (zejména oděvní) - C \& A, H \& M či New Yorker, jež jsou považovány za tahouny mezi oděvními řetězci a za „záruku“ úspěchu u zákazníkủ. Klíčoví obchodníci si také pečlivěji vybírají lokality, kromě obecně přeplněné Prahy je znát menší zájem i o další města, jako je Brno, Plzeň, Liberec či České Budějovice. Některá centra zkoušejí lákat zákazníky na různé zábavní programy - módní přehlídky, autogramiády, výstavy apod. nebo na kulinářské speciality.

Je tedy zřejmé, že v úspěšném nákupním centru je třeba vytvořit prostor jak pro komunitní účely, tak zajistit širší nabídku společenských a sportovních aktivit, služeb i odpočinkových míst. Za úspěšná a již zavedená nákupní centra Ize považovat Nový Smíchov, Chodov, Černý Most a Metropoli Zličín v Praze, Galerii Vaňkovku a Olympii v Brně, ostravský Avion Shopping Park nebo plzeňskou Olympii. Na druhé straně jsou u nás i neúspěšná nákupní centra. $V$ roce 2009 bylo v pražských Stodůlkách uzavřeno první nákupní centrum (umístění mimo stanici metra a mnoho hypermarketů v okolí), s problémy bojují Galerie Nové Butovice, Šestka či Novodvorská Plaza v Praze, brněnské Futurum, plzeňská Plaza a řada dalších.

$\checkmark$ rámci městských struktur bude docházet $\mathrm{k}$ dalšímu pronikání tohoto velkoformátového konceptu do měst o velikosti 50-70 tis. obyvatel, jež svojí populační masou a koupěschopností dokáží středně velké či malé nákupní centrum "uživit". V současné době již v ČR neexistuje padesátitisícové město, kde by nestálo nebo nebylo plánováno nákupní centrum. Investoři se patrně budou také více ohlížet po centrech měst, kde je možné revitalizovat staré opuštěné objekty a přeměnit je na nákupní centra. Tento vývoj není dán primárně tím, že by 
nechtěli stavět v městských centrech, ale spíše nevhodnými podmínkami pro existenci moderního maloobchodu a nevyjasněnými vlastnickými vztahy. Stále vysoká návštěvnost městských center by měla být pro investory nejen impulzem, ale i dostatečnou zárukou.

V souvislosti s pronikáním nákupních center do menších měst je zajímavé sledovat jejich koexistenci s retail parky (kterými se sice $v$ př́spěvku primárně nezabýváme, ale jsou neodmyslitelnou součástí dnešní maloobchodní strategie), jež aktuálně zažívají významný rozmach. Na rozdíl od stotisícových a větších měst se $v$ centrech $s 50$ tis. a méně obyvateli nevytváŕí zóna širšího vnitřního města či velkých sídlišt', a jak centrum, tak periferie jsou velmi dobře dostupné. Retail parky představují možnost, jak přibližit obchodníky i do území, kde je nereálné vybudování klasické obchodní pasáže, resp. nákupního centra. Vhodný mix prodejen a služeb a zájem nakupujících dnes dovolují expandovat retail parkům i do měst o velikosti 15-20 tisíc obyvatel.

Ožehavou a diskutovanou otázkou je výstavba velkých nákupních center na zelené louce na periferii, resp. za administrativní hranicí města. Takto lokalizovaná centra mimo urbánní rezidenční prostory jsou často terčem kritiky jak ze strany urbanistů a městských plánovačů, tak od obyvatel okolních obcí. Obří velkoplošné formáty a rozsáhlá parkoviště zabírají území bez dostatečného respektu ke krajině a životnímu prostředí, podzemní parkoviště jsou v našich podmínkách (zejména s ohledem na finanční nákladnost) nemyslitelná. Je také pravda, že nákupní centrum velikosti pražských Letňan či brněnské Olympie dokáže efektivně zlikvidovat řadu menších obchodů nejen ve svém okolí, ale i v centru města. Celodenní víkendová návštěva (často nejde jen o samotný nákup) nákupního centra se stala trendem i určitou formou životního stylu jak mladé generace, tak i rodin s dětmi a seniorů. Historickým jádrům ubývá návštěvníků.

Na druhé straně lze pozitivně hodnotit výstavbu nákupních center ve velkých sídlištních komplexech, jež jsou často maloobchodně poddimenzovány. Obchodní pasáže, zařízení služeb a zábavy, korza a volné plochy k odpočinku mají tendenci stát se přirozeným místem setkávání lidí a vlastně novým centrem městské části, resp. obecně silně urbanizovaného území. Příkladem budiž úspěšná centra Chodov, Černý Most a Letňany v Praze či perspektivní Campus Square $v$ Brně-Bohunicích. Tato centra mívají velmi dobrou dostupnost jak autem, tak MHD. Také revitalizované objekty v blízkosti městských jader či v širším vnitřním městě jsou $v$ našich podmínkách většinou přínosem pro oživení přirozené obchodní funkce městského centra. Nemusí tomu tak být ovšem vždy, viz opět př́klad z Brna, kde je Galerie Vaňkovka vnímána jako spíše nekonfliktní subjekt vymezující se vůči historickému jádru, ale připravovaná výstavba Auparku v Jižním centru již jako vážná hrozba pro další ztrátu obchodní a obslužné funkce a odliv návštěvníků jádra. 
Tyto obavy mohou být opodstatněné. Studie dopadů otevření nákupního centra The Oracle v Readingu (centrum mělo při otevření 90 obchodů, desetisálový multiplex a 2300 parkovacích míst; celkem 65 tis. $\mathrm{m}^{2}$ prodejní plochy - čímž zvýšilo nabídku ploch ve středu města o $25 \%$ ), které se nachází prímo uprostřed města, zjistila, že důsledky jsou velmi podobné jako v případě out of town center. Dopady v centrální části města byly pouze mírnější, resp. méně intenzivní, protože si střed města díky prítomnosti nákupního centra zachoval atraktivitu a uvolněné prostory po prodejnách, které nevydržely konkurenci The Oracle, se dařilo lépe znovu obsazovat zcela jiným, popř. levnějším sortimentem nebo provozovnami služeb, restauracemi apod. Relativně lépe si vedly menší řetězce, nejvíce otevření nákupního centra dopadlo na malé nezávislé obchodníky. Změny v maloobchodní nabídce a využití nemovitostí, které se odehrávaly v centrální části města (což byla zájmová oblast studie) v závislosti na vzdálenosti od The Oracle, však naznačují, že v okrajových částech města byly negativní dopady silnější (Crosby et al., 2005).

O úspěchu či neúspěchu nákupního centra, po patnácti letech existence tohoto fenoménu na českém trhu, bude tedy rozhodovat již nejen (ne)příznivá ekonomická situace a důležitý mix nájemců, ale stále více i výběr lokality, nabídka zábavy, služeb a programových akcí, schopnost vhodného zasazení do prostředí a v neposlední řadě architektonické ztvárnění. To vše nehledě na politickou vưli výstavbu daného subjektu prosadit. 



\section{Případová studie: Galerie Vaňkovka}

\subsection{Metodika výzkumu a základní informace o šetřeném souboru}

Pro prípadovou studii, která nám umožnila podobnější pohled na nákupní spád a nákupní zvyklosti návštěvníků konkrétního nákupního centra, jsme zvolili jedno z nejznámějších a nejnavštěvovanějších nákupních center v ČR - Galerii Vaňkovka v Brně (viz také Kunc et al., 2010, 2011).

V červnu a záři 2010 se uskutečnilo v Galerii Vaňkovka šetření nákupního spádu a vybraných nákupních zvyklostí návštěvníků. Šetření probíhalo formou standardizovaného dotazníku, a to vždy v průběhu celého týdne, aby byly podchyceny pracovní i volné víkendové dny. Tazateli byli vyškolení studenti Ekonomicko-správní fakulty Masarykovy univerzity, místem šetření se stala centrální obchodní pasáž uvolněná $k$ tomuto účelu vedením Vaňkovky. $V$ intencích doporučené pohlavní a věkové struktury opírající se o hodnoty za Jihomoravský kraj se jednalo o kvótní výběrový vzorek respondentů. Kvótní výběr, jenž imituje ve vzorku známé vlastnosti dané populace, považujeme přes některá úskalí (vliv tazatele a obtižná kontrola jeho práce) pro tyto typy šetření za vhodný metodický přístup.

Datová základna byla opřena o výběrový soubor 1777 respondentů, z nichž bylo $53 \%$ žen a $47 \%$ mužů. Věková struktura byla, s přihlédnutím ke známým skutečnostem, určitým obrazem zájmu osob v určitém věku k návštěvě Vaňkovky. Mladí lidé většinou v predproduktivním věku (do 24 let) jsou, v poměru k věkové struktuře celé české populace, nejsilnější cílovou skupinou (čtvrtina respondentů). Neméně významnou, a do značné míry finančně nezávislejší skupinou, jsou lidé v produktivním věku (25-59 let). Nejméně početně zastoupeným populačním segmentem byli lidé formálně se pohybující za hranicí produktivního věku, s posunem hranice odchodu do důchodu k 65 letům, nezř́íka však stále ekonomicky aktivní.

Vzdělanostní struktura respondentů opět nekorespondovala s celorepublikovou strukturou, byla posunuta $k$ vyššímu dokončenému vzdělání - téměř čtvrtina vzorku měla vysokoškolské vzdělání, více než polovina oslovených dosáhla maturity a u značné části z nich šlo reálně odhadovat studium na vysoké škole.

Trvalé bydliště v Brně uvedlo $43 \%$ dotázaných (viz tabulka 6.1), z nichž téměř všichni (95\%) v Brně i pracovali. Téměř tři pětiny respondentů v Brně nebydlely, ale dvě pětiny z nich v Brně pracovaly. Studenti, kteří neměli trvalé či přechodné bydliště v Brně, tvořili pouze $0,5 \%$ vzorek respondentů, což bylo statisticky 
nevýznamné. Ostatní větší část mimobrněnských ve Vaňkovce pouze nakupovala, projížděla Brnem a zavítala tam k různým přiležitostem apod. Zde se zřetelně projevila lokalizace Vaňkovky mezi dvěma hlavními nádražími - vlakovým a autobusovým - což ji činí jak objektem průchozím, tak místem řady různých setkání a schůzek.

\section{Tab. 6.1: Základní charakteristiky respondentů}

\begin{tabular}{|c|c|c|}
\hline $\begin{array}{l}\text { Pohlaví } \\
\text { muži - } 47 \% \\
\text { ženy - } 53 \%\end{array}$ & $\begin{array}{l}\text { Věk } \\
15-24-25 \% \\
25-59-60 \% \\
60+-15 \%\end{array}$ & $\begin{array}{l}\text { Vzdělání } \\
\text { ZŠ - } 8 \% \\
\text { SŠ bez maturity - } 15 \% \\
\text { SŠ s maturitou - } 54 \% \\
\text { VŠ - } 23 \%\end{array}$ \\
\hline \multicolumn{3}{|c|}{$\begin{array}{l}\text { Bydliště } \\
\begin{array}{ll}\text { v Brně }-43 \% \\
\text { mimo Brno }-57 \% \quad-\text { z toho do Brna dojiždí za prací - } 40 \% \\
\text { - ostatní (pouze nakupují, projíždějí) - } 60 \%\end{array}\end{array}$} \\
\hline
\end{tabular}

Zdroj: Šetření v Galerii Vaňkovka, červen a září 2010.

Respondenti bydlící v Brně strávili cestou do Vaňkovky průměrně 20 minut na rozdíl od bydlících mimo Brno, jejichž cesta trvala téměř 4krát déle. Nerezidenti, ale dojíždějící do Brna za prací, uvedli časový horizont cesty do Vaňkovky téměř 70 minut, což je číslo velmi vysoké a pro denní dojížd'ku do práce (at již autem či veřejnou dopravou) prakticky nereálné. Zde se patrně projevila poloha Vaňkovky v blízkosti centra, jež však nekoresponduje s místem výkonu zaměstnání, ale naopak je zde nutnost přestupů, doplňkového využití MHD či pěší chůze. Pouze ve Vaňkovce nakupujícím či projíždějícím trvala cesta průměrně ještě o 10 minut déle. Podle našich zkušeností z předchozích studií se také projevuje poměrně výrazná zkreslující tendence respondentů časový odhad navyšovat.

\section{Tab. 6.2: Doba cesty do Vaňkovky (průměr v minutách)}

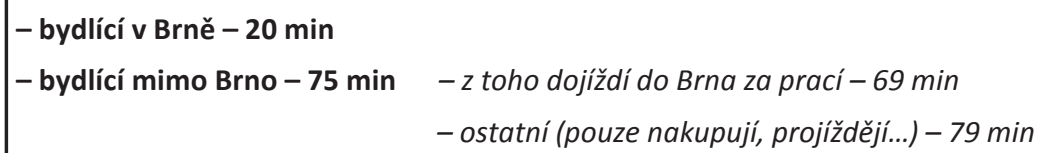

Zdroj: Šetřenív Galerii Vaňkovka, červen a záŕí 2010. 
Obr. 6.1: Prostorové rozmístění respondentů dle trvalého bydliště

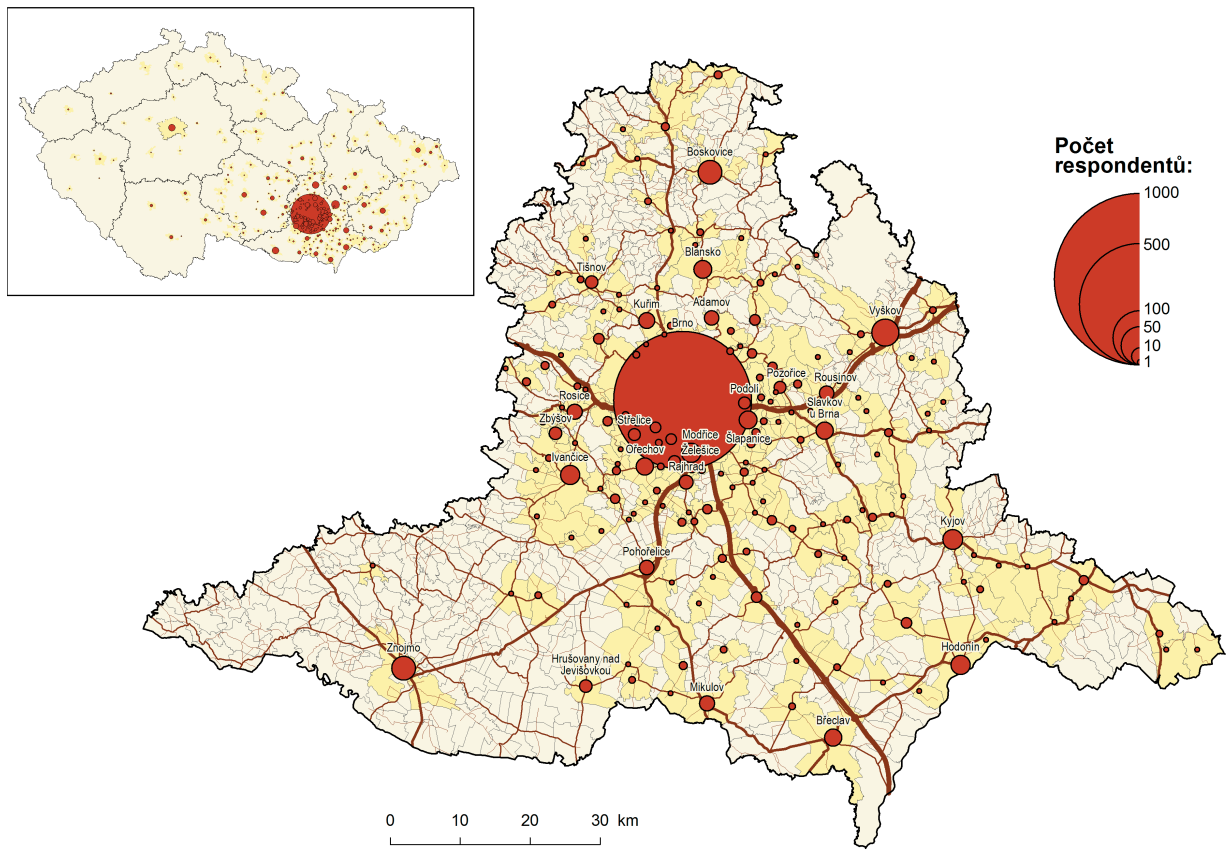

Zdroj: Šetření v Galerii Vaňkovka, červen a září 2010.

\subsection{Vybrané výsledky šetření}

Průměrná doba návštěvy Vaňkovky je zhruba 90-100 minut, ovšem ze zkušenosti víme, že tento odhad je velmi hrubý - nakupující či relaxující lidé nejsou často schopni reálně posoudit uběhnuvší čas. Mladí lidé a lidé v produktivním věku zde stráví asi o 10-15 minut více než senioři. Mimobrněnští respondenti uvedli o 30 minut delší pobyt ve Vaňkovce než ti v Brně bydlící, což je, vzhledem k větším možnostem návštěv Brňanů „dle potřeby“, pochopitelné.

Podobně jako strávený čas je i průměrná útrata návštěvníků během jedné návštěvy Vaňkovky (900-1000 Kč) odpovědí velmi subjektivní. Z uvedených hrubých odhadů nelze vyslovovat významnější závěry, Ize snad poukázat na některé rozdíly, které mohou být obecněji platné. Více jsou schopni utratit lidé v produktivním věku, tedy často zaměstnaní, než mladí a zejména senioři s nižší životní úrovní. Rozdíl je také patrný u dotazovaných v Brně nebydlících, kteří utratí při svých méně frekventovaných nákupech až o několik set korun více než Brňané, kteří sem mohou zavítat častěji, resp. podle potřeby. Tří- a vícečlenné 
domácnosti (většinou rodiny s dětmi) průměrně utratí dle předpokladů o něco více než jedno- a dvoučlenné domácnosti. Zde ovšem vyvstává problém se sebezařazením - do dvoučlenné domácnosti se řadí jak mladé, tak seniorské páry, do jednočlenné dospělí pracující bez závazků, rozvedení a ovdovělí, ale také studenti, kteří mají mimo Brno rodinné zázemí.

\section{Tab. 6.3: Průměrná útrata ve Vaňkovce}

\begin{tabular}{|l|l|l|}
\hline Věk & Vzdělání & Počet členů domácnosti \\
$15-24-750$ Kč & ZŠ -1000 Kč & Jeden -970 Kč \\
$25-59-1100$ Kč & SŠ bez maturity -850 Kč & Dva -800 Kč \\
$60+-650$ Kč & SŠ s maturitou -970 Kč \\
VŠ -1025 Kč & Tři a více -1050 Kč \\
\hline $\begin{array}{l}\text { Bydliště } \\
\text { V Brně }-775 \text { Kč } \\
\text { mimo Brno }-1100 \text { Kč }\end{array}$ \\
\hline
\end{tabular}

Zdroj: Šetření v Galerii Vaňkovka, červen a září 2010.

Ve způsobu dopravy do Galerie Vaňkovka převažuje podle očekávání automobil ( $34 \%$ respondentů, z toho $75 \%$ mimobrněnských) a autobus ( $31 \%$, z toho $80 \%$ mimobrněnských). Zbylých $20 \%$ bydlících v Brně váže svoji dojižd'ku do Vaňkovky na MHD. Tramvaj (21 \% př́ijezdů ze všech dotázaných) je v drtivé většině způsobem dopravy osob bydlících v Brně, na druhé straně u vlaku je tomu právě naopak. Pouze pěšky nebo na kole se do Vaňkovky dopravuje minimum návštěvníků.

\section{Obr. 6.2: Jakým způsobem jste přijeli nakupovat?}
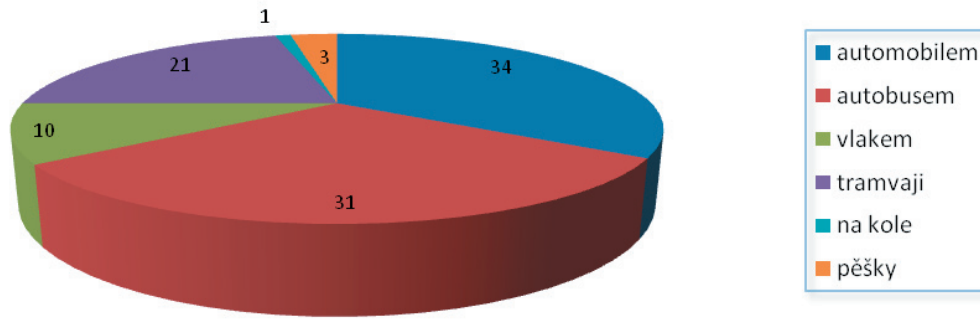

Zdroj: Šetření v Galerii Vaňkovka, červen a zárí 2010. 
Další otázka se vztahovala k četnosti nákupů v Galerii Vaňkovka. Téměř jedna třetina respondentů uvedla, že zde nakupuje príležitostně, což je „standardní odpověd' lidí více pracovně vytižených, kteří si neuvědomují, kolikrát do měsíce tudy vlastně projdou a velmi často i něco nakoupí. Mimobrněnští tuto možnost uvádějí častěji, dotázaní bydlící v Brně se profilují větší pravidelností. Pětina oslovených bydlících $v$ Brně zde nakupuje vícekrát týdně a čtvrtina vícekrát měsíčně. Pouze $1 \%$ Brňanů a $6 \%$ bydlících mimo Brno přiznalo vůbec první návštěvu Vaňkovky.

Obr. 6.3: Jak často nakupujete v Galerii Vaňkovka?

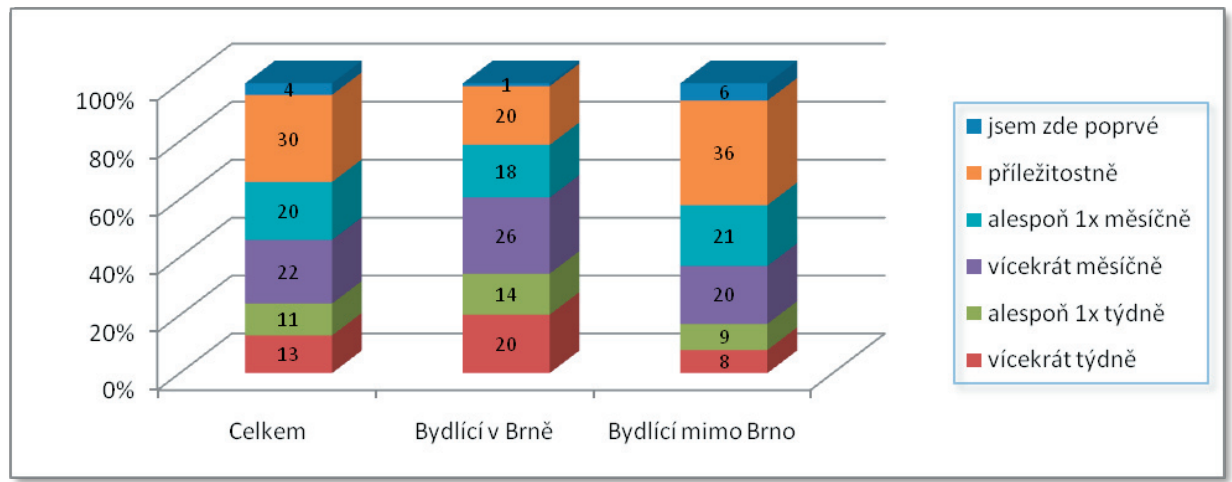

Zdroj: Šetřenív Galerii Vaňkovka, červen a zárí 2010.

Frekvence návštěv vztažená na pracovní týden či víkend vyznívá, i vzhledem k velmi dobře dostupné poloze Vaňkovky, pro pracovní týden, resp. pro návštěvy podle aktuální potřeby. Poměru pracovní týden/příležitostná návštěva ku víkendu Ize vyjádřit intencí 2:1. Drtivá většina oslovených rezidentů (95\%) v Brně také pracuje, $z$ bydlících mimo Brno jich dojiždí za prací do města plné dvě pětiny. Pokud uvažujeme pouze dojíždějící za prací, tak více než polovina (55 \%) jich nakupuje během pracovního týdne, třetina podle aktuální potřeby a zhruba pouze desetina o víkendu. Lze tedy uvést, že ti, co dojížějí do Brna v týdnu za prací, většinou také spojí cestu s nákupem. Jako dopravní prostředek pro dojížd'ku do Brna je nejvíce využíváno auto (55 \%), ostatní jezdí veřejnou dopravou (33\% autobus, $12 \%$ vlak). Na obrázku 6.4 Ize mimo jiné vidět pochopitelný větší zájem o návštěvu Vaňkovky o víkendu u respondentů bydlících mimo Brno. 


\section{Obr. 6.4: Galerii Vaňkovka navštěvujete především?}

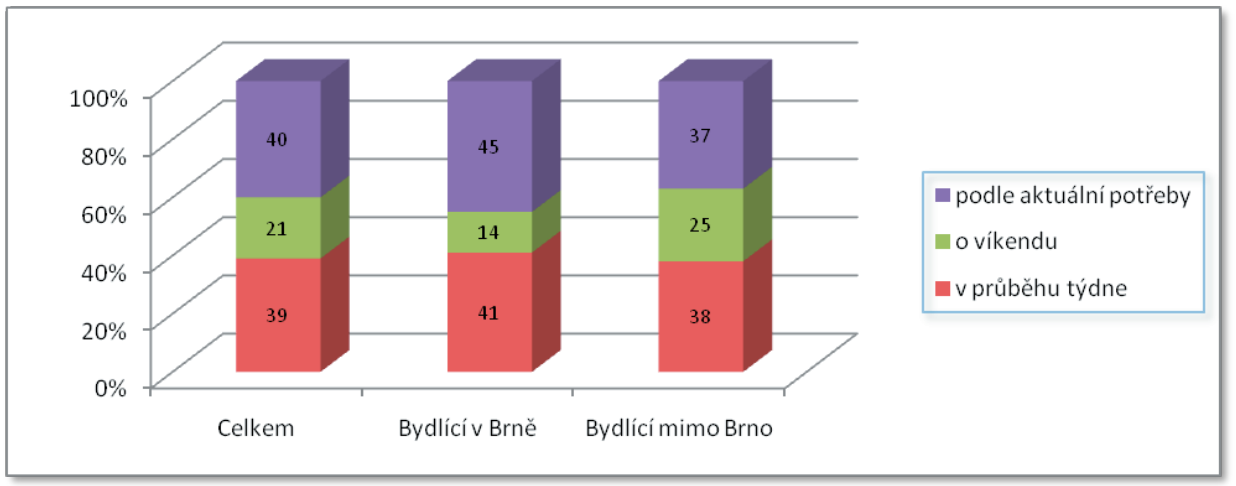

Zdroj: Šetřenív Galerii Vaňkovka, červen a září 2010.

Zhruba třetina dotázaných spojuje svoji cestu do Vaňkovky pouze s nákupem a pětina $s$ cestou do práce či z práce. Na další tři varianty odpověděl přibližně stejný statistický vzorek respondentů - s pracovní nebo soukromou schůzkou, zábavou a volným časem a návštěvou centra města spojuje nejčastěji svoji návštěvu Vaňkovky asi jedna pětina osob. Poslední variantou byly jiné aktivity a zde se zbylých $8 \%$ respondentů nejčastěji přiklánělo k činnostem spojeným s cestováním, což lze opět spojovat s výhodnou polohou Vaňkovky mezi vlakovým a autobusovým nádražím.

Co se týče pohlaví, mají ženy tendenci navštěvovat Vaňkovku cestou do či z práce více než muži, jinak rozdíly mezi pohlavími prakticky nejsou. Dosažená vyšší úroveň vzdělání má vliv na vyšší četnost pracovních nebo soukromých schůzek i na trávení volného času a zábavu - zde se významněji vymezuje skupina osob se středoškolským vzděláním bez maturity. Cestu do práce a z práce spojuje $s$ návštěvou Vaňkovky více respondentů s minimálně maturitním vzděláním, což koresponduje s blízkostí centra a koncentrací institucí, organizací a firem terciárního sektoru. Věková struktura jednoznačně vyčleňuje nejmladší věkovou kategorii a osoby v produktivním věku, jejichž návštěva je značně vázána na cestu z či do školy a práce, na druhé straně si zde mladí lidé přirozeně daleko méně sjednávají pracovní nebo soukromé schůzky. 
Tab. 6.4: Spojitost návštěvy Vaňkovky s aktivitou dle pohlaví, vzdělání a věku

\begin{tabular}{|l|c|c|c|c|c|c|c|c|c|c|}
\hline \multirow{2}{*}{ Varianta/struktura } & Celkem & \multicolumn{1}{|c|}{ Pohlaví (\%) } & \multicolumn{4}{|c|}{ Vzdělání } & \multicolumn{4}{c|}{ Věk } \\
\cline { 5 - 16 } & (\%) & muž & žena & ZŠ & UČ & Sš & VŠ & $\mathbf{1 5 - 2 4}$ & $\mathbf{2 5 - 5 9}$ & $\mathbf{6 0 +}$ \\
\hline cesta do/z práce & 20 & 18 & 23 & 19 & 16 & 22 & 22 & 26 & 21 & 5 \\
\hline návštěva centra & 13 & 13 & 13 & 19 & 9 & 13 & 11 & 14 & 12 & 15 \\
\hline prac./soukromá schůzka & 15 & 16 & 14 & 9 & 17 & 15 & 17 & 7 & 18 & 17 \\
\hline zábava/volný čas & 14 & 14 & 13 & 8 & 18 & 13 & 12 & 12 & 14 & 13 \\
\hline jiné (cestování) & 8 & 8 & 7 & 12 & 6 & 8 & 6 & 11 & 5 & 14 \\
\hline pouze nákup & 31 & 32 & 30 & 34 & 35 & 29 & 32 & 31 & 30 & 35 \\
\hline
\end{tabular}

Pozn.: UČ = středoškolské bez maturity (učňovské).

Zdroj: Šetření v Galerii Vaňkovka, červen a záři 2010.

Polovina respondentů bydlících v Brně spojuje návštěvu Vaňkovky pouze s nákupem, což je zhruba o 10 procentních bodů více než u mimobrněnských. Cestou do či z práce navštěvují Vaňkovku nejvíce dotázaní bydlící mimo Brno, ale dojíždějící do Brna za prací, tento rozdíl je oproti pracujícím mimo Brno podle očekávání přesvědčivý. Na druhé straně využívají mimobrněnští návštěvníci v Brně nepracující Vaňkovku daleko více $\mathrm{k}$ různým schůzkám a návštěvě centra města, což Ize opět považovat za potvrzení předpokladu.

Tab. 6.5: Spojitost návštěvy Vaňkovky s aktivitou dle místa bydliště

\begin{tabular}{|l|c|c|c|}
\hline \multirow{2}{*}{ Varianta/bydliště } & \multicolumn{3}{|c|}{ Bydliště (\%) } \\
\cline { 2 - 4 } & v Brně & $\begin{array}{c}\text { mimo Brno } \\
\text { (dojíždí za prací) }\end{array}$ & $\begin{array}{c}\text { mimo Brno } \\
\text { (nepracují v Brně) }\end{array}$ \\
\hline cesta do/z práce & 27 & 36 & 9 \\
\hline návštěva centra & 14 & 14 & 21 \\
\hline prac./soukromá schůzka & 17 & 15 & 31 \\
\hline zábava/volný čas & 22 & 18 & 18 \\
\hline jiné (cestování) & 5 & 8 & 14 \\
\hline pouze nákup & 51 & 42 & 41 \\
\hline
\end{tabular}

Pozn.: Bylo možno uvést více odpovědí, proto se jedná o četnosti odpovědí, které nejsou prepočteny do $100 \%$.

Zdroj: Šetření v Galerii Vaňkovka, červen a záři 2010. 
Rozdělení času stráveného ve Vaňkovce naznačuje zájem o vybrané typy prodejního sortimentu, služby a další aktivity (viz obrázek 6.5). Nákup oděvů, obuvi a oděvních doplňků tvoří podle výpovědí respondentů více než čtvrtinu celkového času zde stráveného. Trávení volného času, nákupu sportovních potřeb a ostatního zboží věnují respondenti zhruba stejně času, nejméně jsou dle očekávání využívány služby. Nákupu základních potravin věnují návštěvníci asi pětinu zde stráveného času (průměrně 90-100 min).

Vaňkovka rozhodně není místem určeným primárně pro nákup základních potravin a Interspar, bez ohledu na kvalitu, šíri sortimentu a cenovou dostupnost, není magnetem, jako je tomu $v$ jiných prípadech (např. Tesco a v dalších brněnských nákupních centrech Futurum či Královo Pole). Dokládají to také výsledky šetření, kdy potraviny nakupuje nejčastěji právě ve Vaňkovce pouze $10 \%$ respondentů. $V$ prípadě seniorů se jedná o hodnotu dvojnásobnou, což je ovšem typický jev. Mezi ostatními věkovými kategoriemi, pohlavím i věkem není významnějších statistických rozdílů.

Obr. 6.5: Čas strávený ve Vaňkovce dle zájmu o specializované obchody, služby a zábavu (v \%)

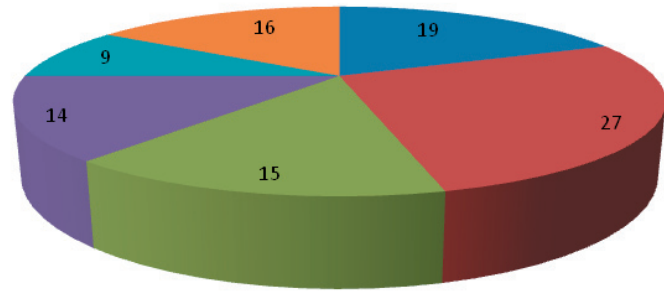

nákup základních potravin

nákup oděvů a obuvi

nákup sportovních potřeb

nákup ostatního zboží

využití služeb

n trávení volného času

Zdroj: Šetření v Galerii Vaňkovka, červen a září 2010.

Dle výpovědí respondentů tráví ženy ve Vaňkovce výrazně více času nakupováním oděvů, obuvi a různých doplňků. Muži naopak tráví více času nákupem sportovních potřeb a chodí do Vaňkovky více za zábavou a trávením volného času. Vzdělanostní struktura není v tomto ohledu nijak významná, Ize snad naznačit, že dotazovaní se základním vzděláním chodí více nakupovat základní potraviny a také oděv a obuv (zkreslení u mladých lidí, jejichž nejvyšší dosažené vzdělání bude u většiny vyšší než základní). 
Tab. 6.6: Čas strávený ve Vaňkovce dle pohlaví, vzdělání a věku

\begin{tabular}{|c|c|c|c|c|c|c|c|c|c|c|}
\hline \multirow{2}{*}{ Varianta/struktura } & \multirow{2}{*}{$\begin{array}{c}\text { Celkem } \\
(\%)\end{array}$} & \multicolumn{2}{|c|}{ Pohlaví (\%) } & \multicolumn{4}{|c|}{ Vzdělání (\%) } & \multicolumn{3}{|c|}{ Věk (\%) } \\
\hline & & muž & žena & Zš & UČ & sš & VŠ & $15-24$ & $25-59$ & $60+$ \\
\hline nákup potravin & 19 & 18 & 20 & 22 & 17 & 18 & 20 & 18 & 18 & 25 \\
\hline nákup oděvů a obuvi & 27 & 24 & 31 & 30 & 27 & 28 & 25 & 32 & 27 & 23 \\
\hline nákup sport. potřeb & 15 & 16 & 13 & 14 & 16 & 15 & 16 & 15 & 16 & 10 \\
\hline nákup ostatního zboží & 14 & 14 & 14 & 14 & 15 & 14 & 15 & 14 & 14 & 16 \\
\hline využití služeb & 9 & 10 & 8 & 8 & 10 & 9 & 8 & 7 & 9 & 11 \\
\hline trávení volného času & 16 & 18 & 15 & 12 & 15 & 16 & 16 & 14 & 16 & 16 \\
\hline
\end{tabular}

Pozn.: UČ = středoškolské bez maturity (učňovské).

Zdroj: Šetření v Galerii Vaňkovka, červen a záři 2010.

Jak již bylo výše řečeno, pro respondenty nad 60 let je Vaňkovka převážně místem nákupu základních potravin, příp. také oděvů a obuvi; méně času než ostatní věkové skupiny se senioři zajímají o sportovní potřeby. Překvapivou skutečností je obdobný časový poměr věnovaný zábavě a trávení volného času u všech tří sledovaných věkových skupin. V tomto případě jsme očekávali určitou převahu mladé či střední generace. Svoji roli zde může hrát i slabší finanční zázemí mladých lidí k návštěvě kaváren, restaurací, fast food provozoven apod., ale i vnímání trávení volného času, který tito věnují pouze prohlížení zboží a „přípravě“ na potenciální nákup. Odpovědi jsou potom často uvedeny jako „nákup“.

Respondenti bydlící v Brně věnují více času nákupu základních potravin než mimobrněnští návštěvníci v Brně nepracující. A právě ti jezdí do Vaňkovky o něco více za zábavou a trávením volného času, ostatní drobné rozdíly jsou statisticky nevýznamné.

A jak se vlastně lidé dozvídají o novinkách v Galerii Vaňkovka? Četnosti odpovědí byly řádově podobné, dle výpovědí respondentů Ize nejvíce vyzdvihnout inzerce v tisku a letáky v MHD, dále pak rádio a rozhlas, magazín Galerie Vaňkovka a internet. Polovina dotázaných chodí pravidelně nakupovat na stejné místo i bez reklamních sdělení, takže jejich nákupní zvyklosti nejsou aktuálně natolik ovlivněny reklamou. Velká část z druhé poloviny návštěvníků se někdy dle inzerce rozhoduje pro nákup určitého zboží, zásadně podle inzerce nakupuje pouze malá část respondentů. O něco častěji nakupují dle inzerce ženy než muži. Výše dosaženého vzdělání zde nemá vliv, avšak věk již ano. Zásadně dle inzerce nakupuje více než pětina respondentů v důchodovém věku, na rozdíl od asi $3 \%$ podílu u mladých lidí a lidí v produktivním věku do 50 let. Návštěvníci Vaňkovky žijící v Brně reagují na inzerci silněji než mimobrněnští. 


\subsection{Shrnutí}

Nákupní spád a nákupní zvyklosti návštěvníků vybraného nákupního centra Ize v teoretické rovině (viz výše v kapitole věnující se teoretickým aspektům) poměrně korektně klasifikovat a třídit. Některé výsledky bude možno zobecnit na centra podobného typu, realita terénního dotazníkového šetření však často odhalí řadu detailů a specifik, jež Ize jen obtižně řadit do „systému“. Neexistence centrálních dat však jiný přístup než anketní šetření nepřipouští a výsledky jsou zajímavé nejen kvůli možnosti potenciální komparace a zobecnění s jinými subjekty, ale i svou informační originalitou.

Galerie Vaňkovka se řadí mezi vnitroměstská centra střední až vyšší cenové úrovně se značnou schopností generovat silný vnitřní i vnější nákupní spád a vyvolat zvýšený městský cestovní ruch spojený s nákupy, relaxací a zábavou. V rámci České republiky patří mezi nejznámější a nejvíce navštěvovaná nákupní centra. Vysoká návštěvnost a obliba je mj. odrazem zdařilé revitalizace bývalé chátrající slévárny v ideální poloze v blízkosti historického centra a mezi hlavním brněnským vlakovým a autobusovým nádražím.

Dílčí výsledky šetření byly průběžně diskutovány v průběhu textu. Zde si shrňme základní zjištěné skutečnosti, které by mohly spíše než k vyslovení rozsáhlých závěrů směřovat k iniciaci dalších obdobných výzkumů umožňujících výsledky porovnat a zhodnotit:

- Do Vaňkovky chodí nakupovat více mladší ženy s maturitním a vyšším dokončeným vzděláním.

- Nadpoloviční většina respondentů nakupujících ve Vaňkovce v Brně bydlí nebo dojíždějí za prací. Na druhé straně je zde velký podíl osob, jež jezdí za nákupy, ale v Brně nebydlí ani nedojíždí do Brna do práce - nadregionální dopad.

- Průměrná délka cesty v rámci Brna trvá zhruba 20 minut, pro mimobrněnské 3,5krát déle.

- Delší čas zde tráví mladí a lidé v produktivním věku, nejvíce utrácejí osoby v produktivním věku a rodiny s dětmi bydlící mimo Brno.

- Ve způsobu dopravy dominuje automobil, autobus a v rámci Brna MHD.

- Převažují příležitostné nákupy jedenkrát či víckrát měsíčně, a to podle potřeby nebo v pracovní dny.

- Cesta do Vaňkovky je nejčastěji spojena přímo s vlastním nákupem, cestou z či do práce a pracovní nebo soukromou schůzkou; jedná se více o osoby s vyšším dosaženým vzděláním v produktivním věku. Brňané zde nejvíce jen nakupují, dojíždějící za prací do Brna spojují svoji návštěvu nejčastěji právě s cestou z či do práce. 
- Ženy stráví nejvíce času nákupem obuvi, oděvů a oděvních doplňků, muži nákupem sportovních potřeb, mají také zvýšený zájem o zábavu a volnočasové aktivity - v obou př́padech se jedná o mladší či střední generaci.

- Nemalý podíl stráví návštěvníci také nákupem základních potravin, ve zvýšené míře se jedná o osoby ve vyšším věku. Brňané tráví nákupem základních potravin více času než mimobrněnští, kteří preferují zábavu a volný čas.

- Polovina dotázaných nemění své základní nákupní zvyky v souvislosti s reklamou. Reklamní sdělení potom jednoznačně nejvíce ovlivňují osoby $v$ důchodovém věku.

Galerie Vaňkovka návštěvníky přitahuje. Stala se fenoménem a celorepublikovým pojmem. Lidé sem nechodí pouze nakupovat, ale mívají zde i schůzky pracovního či soukromého rázu, $\mathrm{k}$ čemuž je motivuje i povědomí velmi dobré možnosti parkování. Vaňkovka však není jen nákupním centrem s desítkami specializovaných obchodů, ale prostorem s galeriemi a volnými plochami, kde se konají různé výstavy, expozice, kulturní akce apod. Již více než 5 let plní funkci komerčního, ale i kulturního a přijemného živého organismu, v němž se vhodně doplňuje dynamika a kultivovanost. $V$ poměrně blízké budoucnosti se Vaňkovka prostorově i funkčně začlení do nově zbudované městské části Jižní centrum a je pravděpodobné, že se stane jeho vlajkovou lodí. 



\section{Brněnská aglomerace: denní i nedenní dojížd'ka za maloobchodem, nákupní spád a nákupní chování obyvatel v zázemí Brna}

\subsection{Metodika výzkumu}

Pro účely našeho výzkumu jsme zvolili jeden z možných způsobů, tedy dotazování $v$ domácnostech a na ulici, resp. v místě bydliště respondentů, což je způsob poměrně časově náročný. Základním souborem výzkumu byli obyvatelé obcí, u kterých byla dojižd'ková vzdálenost do centra Brna ohraničena izochronou 30 minut. Jedná se o obce okresů Brno-venkov, Blansko, Břeclav, Vyškov, Znojmo a Žd'ár nad Sázavou, jež splňují podmínku časové dostupnosti. Obce okresu Brnovenkov, který představuje přirozenou spádovou oblast brněnské aglomerace, jsme do základního soboru zahrnuli všechny.

Předpokládali jsme, že významnou roli při rozhodování o dojížd'ce za nákupy totiž sehrává čas a vzdálenost potřebné pro dosažení cíle dojížd'ky. Izochrony s hranicí 30 minut považujeme za dojížd'kovou vzdálenost, kdy jsou lidé do značné míry ochotni za nákupy dojíždět mimo své bydliště. Na všech kartografických výstupech jsou zřejmé časoprostorové výběžky lemující dálnice a rychlostní komunikace paprskovitě se rozbíhající ven z Brna, ale také „ostrov“ města Adamov ( 5 tis. obyvatel) a okolních obcí v jižní části okresu Blansko. Toto území je velice nepřiznivě dopravně napojeno na centrum Brna a $v$ důsledku přírodních bariér (hluboké údolí řeky Svitavy) trvá cesta autem na Hlavní nádraží v Brně déle než vlakem.

Základní soubor tvořilo celkem 228 obcí, v nichž ke konci roku 2010 bydlelo 252 tisíc obyvatel. Největší obcí byla Kuřim s 10,8 tisíci obyvateli a nejmenší Řikonín s 33 obyvateli. Výběrový soubor obsáhl celkem 6300 respondentů starších 15 let trvale žijících v daných obcích. Výběr dotazovaných měl podobu dvoustupňového kvótního výběru, kdy byly v první fázi nejdřive zvoleny počty respondentů pro jednotlivé obce proporcionálně $k$ jejich celkové populaci (počet respondentů se dle velikosti obce pohyboval v rozpětí od 10 do 100) a v druhé fázi byli vybíráni respondenti na základě kvótního výběru dle základních demografických znaků (pohlaví, věk) proporcionálně k průměru populace Jihomoravského kraje.

Dotazníkové šetření bylo realizováno formou standardizovaných rozhovorů pomocí vyškolených tazatelů (studentů Masarykovy univerzity v Brně). Proběhlo v období květen-listopad 2010. Otázky dotazníku se zaměřily na místo nákupů, 
frekvenci, denní (ne)pravidelnost a způsob přepravy k nákupům základních potravin, spojitost nákupů základních potravin s cestou z (do) práce či jinou činností a další. $V$ následující části byly otázky orientovány na návštěvu nákupních center $v$ Brně, kde jsme zkoumali opět frekvenci a pravidelnost, způsob přepravy a spojitost nákupů s jinou činností, upřednostňování určitého typu sortimentu či služeb, ale také motivační faktory $\mathrm{k}$ nákupům $v$ nákupních centrech, vliv reklamy na intenzitu nákupů, průměrný strávený čas a průměrnou výši útraty v centru. To vše v kontextu základní demografické struktury (pohlaví, věk, vzdělání, počet členů domácnosti) a místa bydliště a pracoviště.

Cílem výzkumu bylo ověřit následující hypotézy:

- Denní dojížd'ka za maloobchodem je determinována převážně socioekonomickými a geografickými faktory. Rozhodující je místo výkonu zaměstnání, velikost obce a její vzdálenost od Brna př́padně jiného lokálního centra, přičemž spotřebitelé upřednostňují lokální nabídku a minimální mobilitu za nákupy.

- Intenzita a směr nedenní dojížd'ky za nákupy (návštěvy nákupních center) jsou výrazněji ovlivněny sociodemografickými charakteristikami jedinců (věk, vzdělání, ekonomická aktivita) a jejich osobními motivacemi nákupního chování. Dojížd'ková vzdálenost nehraje zásadní roli, důležitější je kombinace širre nabídky potravinářského a stále více i nepotravinářského sortimentu a možnosti tráveni volného času.

- Nákupní centra, zejména na okraji města, se kromě nedenních návštěv spojených s nákupy a zábavou stávají také těžištěm denních nákupů základních potravin. Jedná se o významnou změnu socioprostorových preferenci v souvislosti s nákupním chováním obyvatel v zázemí větších měst.

\subsection{Nákupy základních potravin}

Jednoduchá typologie vizualizovaná na obrázku 7.1 představuje převažující směr (více než $50 \%$ ) nákupů základních potravin. Více než polovina šetřené populace (54 \%) nakupuje základní potraviny převážně v místě bydliště, zbylá část stejným dílem (23\%) v Brně či v jiné obci. Při členění dle počtu obcí dojde k růstu podílu převažujících nákupů v místě bydliště ( $60 \%$ obcí) a v jiné obci (30\%), naopak poklesne podíl centrálního Brna. 


\section{Obr. 7.1: Typologie převažujícího spádu nákupu základních potravin}

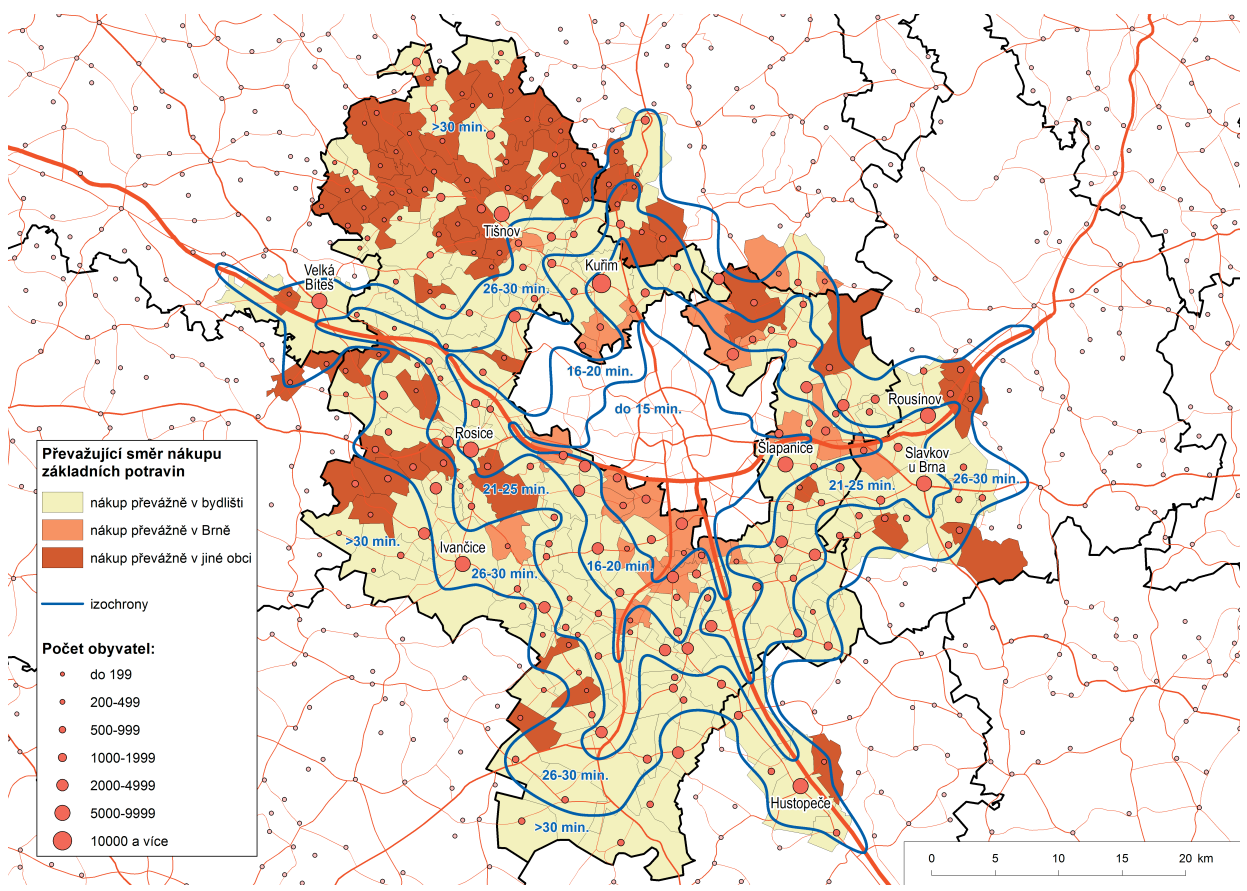

Zdroj: Šetření v zázemí Brna, květen-listopad 2010.

V př́padě nákupu prevážně v místě bydliště (typ 1) se jedná zejména o populačně větši obce v prostoru, kde denní nákup základních potravin obyvatelé řeší $v$ rezidenční obci v důsledku solidní vybavenosti maloobchodními zařízeními.

Nákup převážně v Brně (typ 2) preferují obyvatelé k Brnu přilehlých obcí, kde je bezproblémová možnost dojižd'ky za nákupem (MHD, IDS), přičemž většina obyvatel v Brně také pracuje. Typ 3 , tedy nákup převážně v jiné obci, je nutností pro obyvatele populačně menších obcí s nedostatečnou maloobchodní infrastrukturou. Na obrázku 7.2 Ize vidět zázemí několika lokálních spádových center, z nichž se nejvýrazněji profiluje periferně položené Tišnovsko, které leží také téměř celé mimo izochronu 30 minut. 
Obr. 7.2: Zázemí lokálních center při převažujícím spádu za nákupem základních potravin

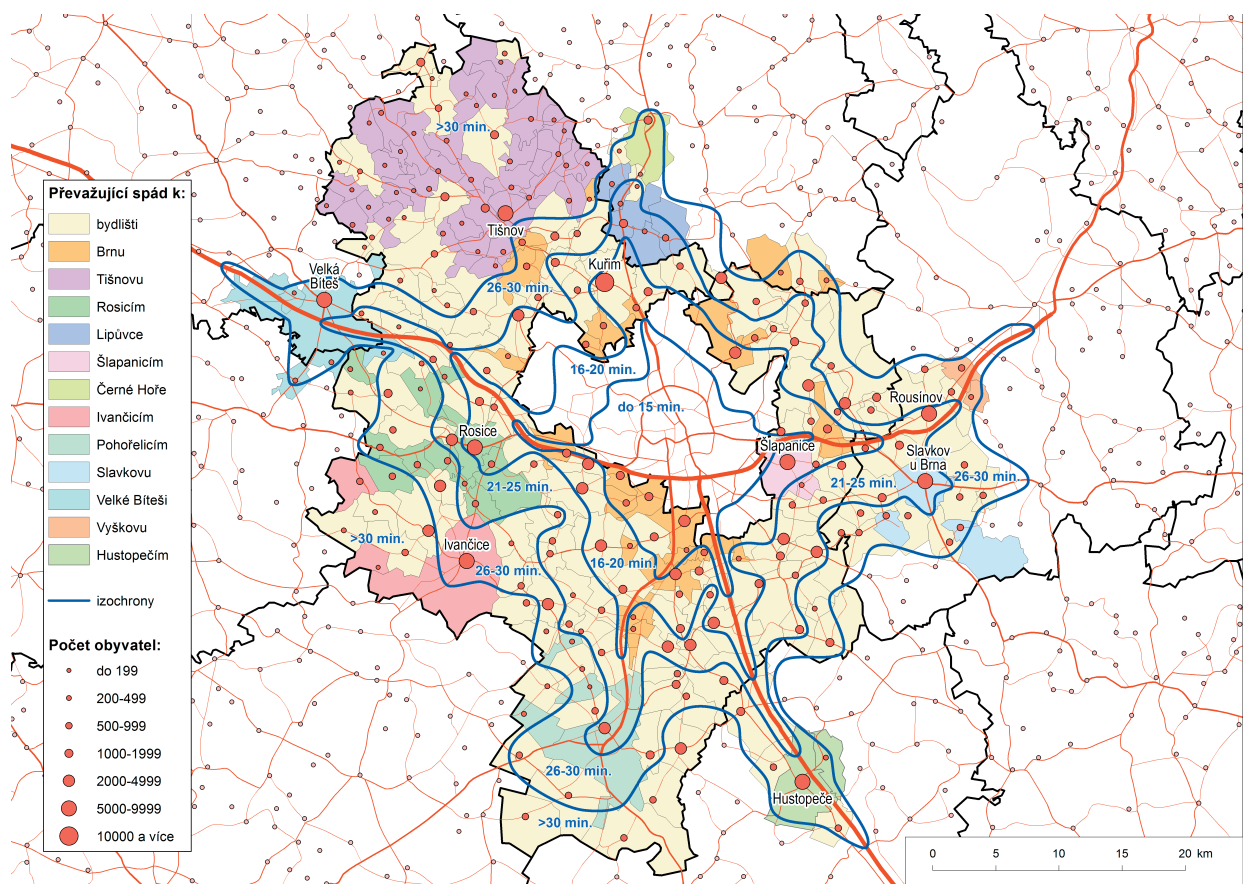

Zdroj: Šetření v zázemí Brna, květen-listopad 2010.

Z analýz vyplývá, že s velikostí obce roste počet nakupujících základní potraviny přímo v obci ( $v$ obcích nad 2 tis. obyvatel až $70 \%$ všech nákupů) a výrazně klesá počet vyjíždějících za nákupy do jiné větší obce či města ve svém okolí. Do Brna jezdí nakupovat zhruba čtvrtina osob, výjimkou jsou pouze nejmenší obce do 200 obyvatel (asi $10 \%)$. S rostoucí časovou vzdáleností od středu města také klesá zájem nakupovat základní potraviny převážně v Brně. S výjimkou nejkratšího časového intervalu převažuje nákup základních potravin v místě bydliště. S rostoucí časovou vzdáleností od Brna využívají obyvatelé menších obcí možnost snadnější denní dojižd'ky do většího střediska v blízkém okolí, jež má dostatečnou maloobchodní vybavenost.

Více než polovina obyvatel obcí vyjiždí za nákupy základních potravin do Brna pouze z několika málo obcí v bezprostředním zázemí a Ize potvrdit očekávanou skutečnost, že s časovou vzdáleností tento podíl klesá. Svou roli zde opět hraje kvalita dopravní infrastruktury, resp. existence silnic vyšších tříd a intenzita dopravní obslužnosti. 


\section{Obr. 7.3: Vyjíždějící za nákupy základních potravin do Brna}

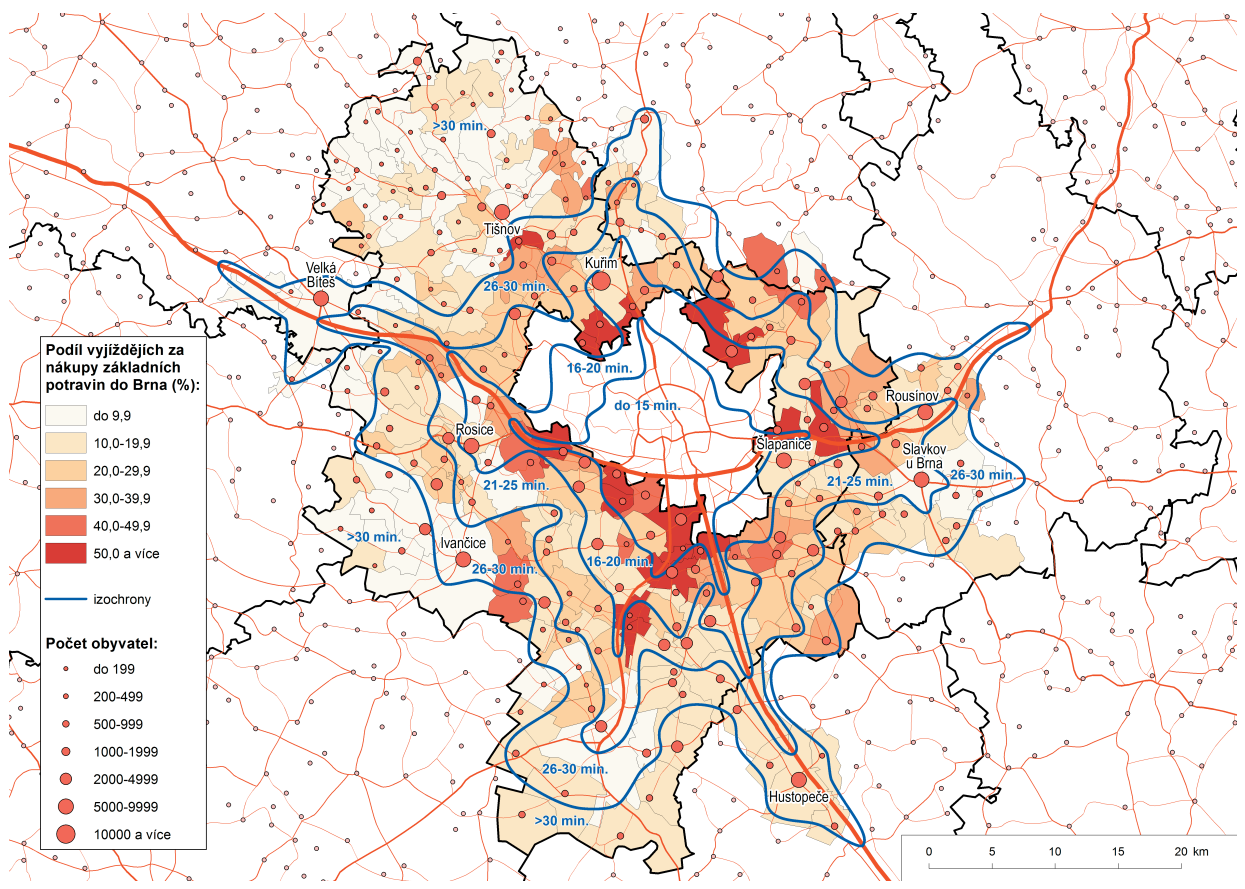

Zdroj: Šetření v zázemí Brna, květen-listopad 2010.

Frekvence nákupu základních potravin je provázána také s převažujícím směrem nákupu $v$ kontextu provedené typologie (převážně $v$ místě bydliště, převážně v Brně, převážně v jiné obci). Denní frekvenci nákupu základních potravin preferuje zhruba $30 \%$ respondentů a činí tak rozhodujícím způsobem v místě bydliště ( $80 \%$ odpovědí v dané obci). Polovina obyvatel nakupuje víckrát týdně, a to $v$ místě bydliště ( $60 \%$ odpovědí) a občas v Brně. Jedenkrát týdně nakupuje základní potraviny $16 \%$ dotázaných, přičemž spádovým místem se v polovině případů stává centrální Brno, v menší míře potom místo bydliště. Rozhodujícím způsobem ( 80 \% odpovědí) se profiluje Brno v nejméně četné frekvenci nákupu základních potravin - víckrát měsičně - přičemž takto nakupují pouhá $4 \%$ respondentů. Je zřejmé, že se snižující se frekvencí nákupu základních potravin roste význam šíre nabídky maloobchodní sítě města Brna, ovšem ve velmi malých absolutních hodnotách. 
Tab. 7.1: Frekvence nákupu základních potravin dle vybraných charakteristik

\begin{tabular}{|l|l|}
\hline $\begin{array}{l}\text { Frekvence nákupu } \\
\text { základních potravin }\end{array}$ & Vybrané charakteristiky \\
\hline Denně & $\begin{array}{l}\text { - typicky lidé z velkých rodin (4 a více členů), nejčastěji prímo v obci } \\
\text { (pěšky) }\end{array}$ \\
\hline Víckrát týdně & $\begin{array}{l}\text { - nerozhoduje ani počet členů domácnosti, ani způsob dopravy a mís- } \\
\text { to nákupu }\end{array}$ \\
\hline Jedenkrát týdně & - typicky „singles“ a malé rodiny, převážně jedou do Brna autem \\
\hline Několikrát měsíčně & $\begin{array}{l}\text { - nerozhoduje ani počet členů domácnosti, ani způsob dopravy a mís- } \\
\text { to nákupu }\end{array}$ \\
\hline
\end{tabular}

Zdroj: Vlastní šetření.

Z odpovědí dotázaných Ize vysledovat také vazbu nákupů základních potravin na průběh týdne. V pracovní části týdne nakupuje většina obyvatel (70\%), a to převážně v místě bydliště ( $60 \%$ odpovědí v dané obci) a někdy v Brně. Víkendový nákup základních potravin je minimální (5\% respondentů) a místem nákupu je převážně Brno. Čtvrtina dotázaných nakupuje dle potřeby, a to převážně v místě bydliště (60 \% odpovědí). Ve způsobu dopravy za nákupem základních potravin převažuje možnost jít pěšky (44 \%) a jet automobilem (37\%), daleko menší podíly zaznamenává veřejná doprava a kolo (15, resp. 5 \%). Následující tabulka 7.2 přehledně prezentuje vztah mezi místem nákupu základních potravin a způsobem dopravy v kontextu výše uvedené typologie převažujícího směru nákupu.

Tab. 7.2: Vztah mezi místem nákupu základních potravin a způsobem dopravy

\begin{tabular}{|l|c|c|c|}
\hline \multirow{2}{*}{ Způsob dopravy } & \multicolumn{3}{|c|}{ Převažující směr nákupu } \\
\cline { 2 - 4 } & Převážně v obci & $\begin{array}{c}\text { Převážně v jiné obci } \\
\text { v okolí }\end{array}$ & Převážně v Brně \\
\hline Auto & $19 \%$ & $39 \%$ & $42 \%$ \\
\hline Veřejná doprava & $18 \%$ & $40 \%$ & $42 \%$ \\
\hline Kolo & $86 \%$ & $11 \%$ & $3 \%$ \\
\hline Pěšky & $93 \%$ & $5 \%$ & $2 \%$ \\
\hline
\end{tabular}

Zdroj: Šetření v zázemí Brna, květen-listopad 2010.

Významný vztah existuje také v případě dojížd'ky za prací a za nákupy. Z tabulky 7.3 zřetelně vyplývá vazba práce v místě bydliště a převažující forma nákupu základních potravin tamtéž. Podobný způsob nákupu preferují také matky na mateřské dovolené a důchodci, kteří se pohybují převážně ve své obci. 
V okolních větších lokálních střediscích (Blansko, Tišnov, Rosice, Slavkov u Brna, Pohořelice a další) nakupují převážně ti, kteří tam také jezdí do práce. $V$ Brně potom nakupují základní potraviny převážně zde také pracující či studující (trvale bydlící či dojíždějící) respondenti.

Tab. 7.3: Vztah mezi místem nákupu a dojížd'kou do zaměstnání

\begin{tabular}{|l|c|c|c|}
\hline \multirow{2}{*}{ Místo práce } & \multicolumn{3}{|c|}{ Převažující směr nákupu } \\
\cline { 2 - 4 } & $\begin{array}{c}\text { Převážně } \\
\text { v obci }\end{array}$ & $\begin{array}{c}\text { Převážně v jiné obci } \\
\text { v okolí }\end{array}$ & $\begin{array}{c}\text { Převážně } \\
\text { v Brně }\end{array}$ \\
\hline V místě bydliště & $62 \%$ & $12 \%$ & $26 \%$ \\
\hline V okolí obce & $45 \%$ & $49 \%$ & $6 \%$ \\
\hline V Brně & $33 \%$ & $12 \%$ & $56 \%$ \\
\hline Důchodce, mateřská dovolená & $68 \%$ & $22 \%$ & $10 \%$ \\
\hline Student & $47 \%$ & $15 \%$ & $38 \%$ \\
\hline
\end{tabular}

Zdroj: Šetření v zázemí Brna, květen-listopad 2010.

Nákup základních potravin spojený s cestou z práce (příp. do práce) je typický pro obyvatele ( $37 \%$ respondentů), kteří pracují v Brně nebo v jiném větším městě v okolí bydliště (Blansko, Tišnov apod.). Cestu z práce tak využijí k nákupu, nejčastějším způsobem dopravy je auto. Pouze na nákup vyráží polovina respondentů, a to především těch, kteří nakupují v místě bydliště, přičemž $50 \%$ z tohoto dílčího vzorku nevykonává pravidelnou pracovní činnost (důchodci, matky na mateřské dovolené, nezaměstnaní). Vazba místa výkonu zaměstnání tedy významně ovlivňuje místo nákupu a nákupní zvyklosti.

\subsection{Nákupní centra}

Brno patři v České republice mezi ta města, kde se relativně brzy, na charakter transformace českého maloobchodu, začala stavět nákupní centra a kde již ke konci roku 1996 byl pro veřejnost otevřen vůbec první velký hypermarket na území státu - Globus (Szczyrba, 2010). S jistou nadsázkou Ize říci, že se Brno stalo místem pro testování nákupního chování a výsledky z četných dotazníkových průzkumů, které stavbě prvních velkoplošných prodejen předcházely a jichž se také účastnil jeden $z$ autorů príspěvku, sloužily $k$ další specifikaci expanze velkoplošného maloobchodu v ČR. A jak vidno i z následující tabulky 7.4, ochota zákazníků $v$ Brně a širším okolí změnit své nákupní zvyky rychle přivedla zahraniční developery do města, aby zde realizovali své hypermarkety nebo nákupní centra. 
7. BRNĚNSKÁ AGLOMERACE: DENNÍ I NEDENNÍ DOJÍŽĎKA ZA MALOOBCHODEM...

Tab. 7.4: Největší nákupní centra v Brně

\begin{tabular}{|l|c|c|c|c|c|}
\hline Název & $\begin{array}{c}\text { Rok } \\
\text { otevření }\end{array}$ & $\begin{array}{c}\text { Lokalizace } \\
\text { v rámci města }\end{array}$ & $\begin{array}{c}\text { GLA } \\
\mathbf{v ~ m}^{2}\end{array}$ & $\begin{array}{c}\text { Počet } \\
\text { jednotek }\end{array}$ & $\begin{array}{c}\text { Relativní } \\
\text { návštěvnost }\end{array}$ \\
\hline Globus hypermarket* & 1996 & periferie & 13500 & 15 & $31 \%$ \\
\hline Avion Shopping Park & 1998 & periferie & 60100 & 58 & $20 \%$ \\
\hline Olympia & 1999 & $\begin{array}{c}\text { sousední obec } \\
\text { (Modřice) }\end{array}$ & 111000 & 220 & $43 \%$ \\
\hline Futurum & 2001 & periferie & 32300 & 70 & $19 \%$ \\
\hline Královo Pole & 2004 & širší vnitřní město & 21400 & 68 & $15 \%$ \\
\hline Galerie Vaňkovka & 2005 & vnitřní město & 37000 & 130 & $26 \%$ \\
\hline Campus Square & 2007 & sídliště & 22000 & 52 & $5 \%$ \\
\hline
\end{tabular}

Zdroj: Internetové stránky nákupních center; Centers DATA 2010; vlastní výzkum.

* Globus hypermarket neni typickým nákupním centrem dle standardních mezinárodních definic. Součásti areálu Globusu je hobbymarket Baumarkt a v těsné blízkosti leži také nově vybudovaný hobbymarket Bauhaus. Vzhledem k místním specifikům, kdy na severní periferii Brna je Globus jediným velkoformátovým komplexem s velmi rozsáhlým nákupním spádem, byl tento zařazen do výzkumu i prezentovaných výsledků.

Pozn.: Část údajů již obsahuje tabulka 5.7. na str. 78.

Nákupní centra mají pro obyvatele obcí brněnské aglomerace daleko větší atraktivitu, než je pouze nákup základních potravin. Většinu svých nákupů potravin, ve srovnání s dalšími maloobchodními koncepty, zde uskutečňuje necelá polovina obyvatel řešeného území (45\%), přičemž se nejedná o denní nákup, a ten je často spojen také s jinou činností (zábava, volný čas). Z většiny šetřených obcí vyjižclí do nákupních center za jakoukoliv formou nákupu, využití služeb či zábavy minimálně polovina respondentů (čím blíže k Brnu, tím je podíl větší), podívejme se proto na nákupní zvyklosti obyvatel v zázemí Brna spojené s nákupními centry podrobněji.

Plné dvě třetiny respondentů (67 \%) odpověděly, že navštěvují velká nákupní centra na okraji Brna. S rostoucím věkem dle očekávání klesá relativní četnost návštěv, přičemž mladých do 35 let jezdí do nákupních center až 85 \%, seniorů nad 65 let pouze $30 \%$. S rostoucím vzděláním naopak poněkud překvapivě výrazně roste četnost návštěv - nákupní centrum navštěvuje téměř $90 \%$ oslovených vysokoškoláků, na druhou stranu ani ne polovina osob se základním vzděláním. Velikost obce nemá pro rozhodnutí o návštěvě nákupního centra zásadní vliv, o něco více jezdí obyvatelé v nejbližším zázemí Brna (do 15 km).

Pokud respondenti pracují prímo v Brně nebo se jedná o studenty, je četnost návštěv nákupních center až $90 \%$ z šetřeného dílčího vzorku. U respondentů pracujících v obci či blízkém okolí obce se snižuje četnost návštěv nákupních center na zhruba $2 / 3$. Pouze necelá polovina důchodců a matek na mateřské dovolené, 
tedy většinou méně mobilních a finančně nezávislých osob, jezdí do některého z brněnských nákupních center.

Téměř třetina dotázaných vykazuje frekvenci návštěv jedenkrát či víckrát měsíčně, denně je to pouze $1 \%$. Nejčastěji jezdí mladší, do 35 let, nejméně často senioři. Velikost obce nerozhoduje, čím blíže je obec k Brnu, tím častěji jezdí její obyvatelé do nákupního centra nakupovat. Průběh týdne nemá na návštěvu nákupního centra zásadní vliv, lidé jezdí pouze o něco více o víkendu (39\%) než v pracovní dny či různě podle potřeby. Mladší respondenti (až polovina odpovědí) jezdí častěji o víkendu než ostatní populační segmenty, což potvrzuje skutečnost trávení volného času a zábavy v nákupních centrech o víkendu. Vzdělání obyvatel, velikost obce ani vzdálenost od Brna nehraje při rozhodování o návštěvě NC významnější roli.

S čím je nejvíce spojena cesta za nákupem či návštěvou nákupního centra? Zde se podle předpokladů prakticky neprojevila, na rozdíl od nákupu základních potravin, spojitost s pracovními aktivitami, resp. místem zaměstnání. Pouze $15 \%$ respondentů spojuje svoji práci s následným nákupem v centru, 23 \% s jinou činností (nejčastěji zábavou a volným časem, ale i s využitím služeb) a více než 3/5 obyvatel jezdí do nákupních center pouze nakupovat širší sortiment zboží. Střední generace, většinou ekonomicky aktivní mezi 35-60 rokem života, spojuje častěji nákup s cestou ze (popř. do) zaměstnání než mladší do 35 let, kteří preferují nákup s trávením volného času. Osoby v důchodovém věku jezdí nejčastěji cíleně pouze za nákupem. Vzdělání obyvatel, velikost obce ani vzdálenost od Brna nemá významnější vliv.

Drtivá většina osob jezdí na nákupy do nákupních center autem (87 \%), jedná se především o střední generaci s vyšším vzděláním, pravidelnými pracovními návyky a přiměřenou finanční situací. Mladší respondenti a senioři využívají hojně také veřejnou hromadnou dopravu. Čím menší je obec a čím dále leží od Brna, tím častěji její obyvatelé využívají auto. Výjimkou je Galerie Vaňkovka v bezprostřední blízkosti centra města, při jejiž návštěvě je nadprůměrně využívána veřejná doprava a městská hromadná doprava.

Průměrný čas strávený $v$ nákupním centru se pohybuje nejčastěji mezi 30-60 min (30 \% respondentů), resp. 90-120 min (28 \%), průměr všech odpovědí je 110 min. Delší dobu zde stráví mladší a střední generace, nejvyšší útratu mají podle předpokladu lidé v produktivním věku. Vzdělání, velikost obce ani vzdálenost od Brna nehrají při členění významnější roli. Rozdělení času stráveného v nákupních centrech naznačuje zájem o agregované typy prodejního sortimentu, služby a další aktivity. Nákup oděvů, oděvních doplňků a obuvi tvoří podle výpovědí respondentů více než čtvrtinu celkového času zde stráveného. Trávení volného času, nákupu sportovních potřeb a ostatního zboží věnují respondenti zhruba stejně času (asi $15 \%$ ), nejméně jsou dle očekávání využívány služby. Nákupu základních potravin věnují návštěvníci asi pětinu zde stráveného času. 
Co se týče pohlaví, ženy tráví v nákupních centrech výrazně více času nakupováním oděvů, obuvi a různých doplňků. Muži tráví více času nákupem sportovních potřeb a využívají také více možností zábavy a trávení volného času. Vzdělanostní struktura nevykazuje významnější statistické rozdíly, Ize snad naznačit, že dotazovaní se základním vzděláním chodí více nakupovat základní potraviny a také oděvy a obuv. Tato skutečnost může být zkreslena u mladých lidí, jejichž dosažené vzdělání je většinou vyšší než základní. Pro seniory jsou nákupní centra převážně místem nákupu základních potravin, příp. také oděvư a obuvi, o ostatní sortiment jeví nižší zájem. Nejčastější útrata se pohybuje mezi 500-1000 Kč, resp. 1500-2000 Kč (zhruba čtvrtina odpovědí v obou případech), průměrná útrata činí 1600 Kč.

Největším motivačním faktorem pro návštěvu nákupního centra je širší sortiment zboží a možnost většího výběru (51 \% odpovědí), úspora peněz (30 \%), úspora času a aktivity spojené s nákupem (např. zábava) převažují překvapivě pouze u zhruba $10 \%$ respondentů. Z dalších zpracovaných dat ovšem víme, že pokud bychom vynechali z hodnocených nákupních center hypermarket Globus, jenž formálně nesplňuje kritéria pro zařazení mezi nákupní centra, posouvá se atraktivita nákupního chování u zábavy a volnočasových aktivit do podstatně vyšších hodnot. Ukazují to mj. zkušenosti z šetření přímo v nákupních centrech. Pro trávení volného času a zábavu je podle očekávání nejvíce využívána Olympia a Galerie Vaňkovka, nejméně pak Futurum. Největší úsporu peněz a širší sortiment má dle odpovědí Globus a Avion Shopping Park. Úspora času je naopak nejvíce negativně vnímána $v$ Olympii, kde se strávený čas skutečně často stává pouze časem „utraceným“.

A jak se vlastně lidé dozvídají o novinkách v nákupních centrech? Nejvíce Ize vyzdvihnout inzerce $v$ tisku a letáky $v$ MHD, dále pak rádio a rozhlas, vlastní magazíny a internet. Polovina dotázaných chodí pravidelně nakupovat na stejné místo i bez reklamních sdělení, takže jejich nákupní zvyklosti nejsou aktuálně natolik ovlivněny reklamou. Velká část z druhé poloviny návštěvníků se někdy dle inzerce rozhoduje pro nákup určitého zboží, zásadně podle inzerce nakupuje pouze malá část respondentů. O něco častěji nakupují dle inzerce ženy než muži. Výše dosaženého vzdělání zde nemá vliv, avšak věk již ano. Zásadně dle inzerce nakupuje více než pětina respondentů v důchodovém věku, na rozdíl od asi $3 \%$ podílu u mladých lidí a lidí v produktivním věku do 50 let. 
Obr. 7.4: Spádové území dvou nejsilnějších maloobchodních subjektů v Brně - hypermarket Globus a nákupní a zábavní centrum Olympia

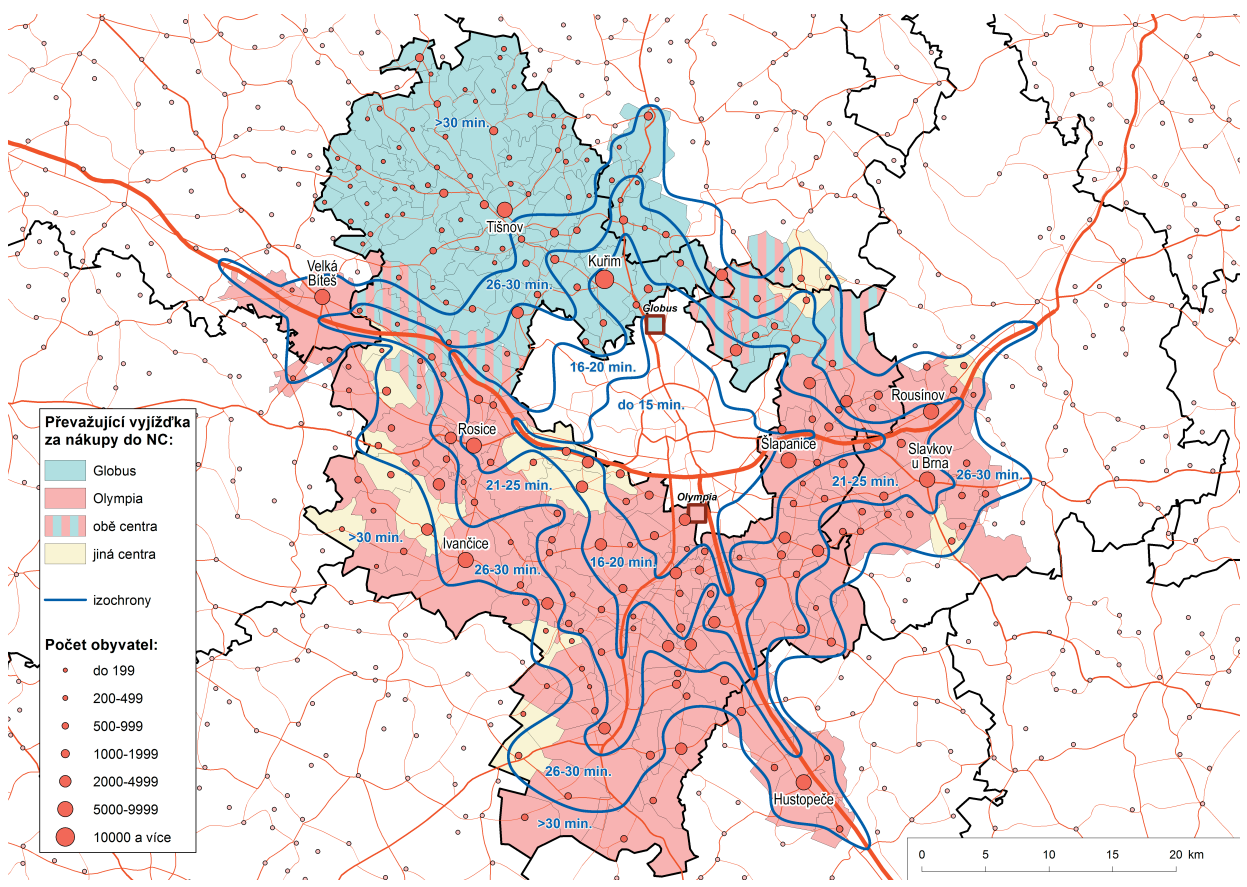

Zdroj: Šetření v zázemí Brna, květen-listopad 2010.

Na obrázku 7.4 jsou představeny oblasti dvou spádově nejsilnějších maloobchodních zařízení brněnské aglomerace, kam obyvatelé jezdí nakupovat a trávit volný čas - Obchodní centrum Olympia Brno a hypermarket Globus (min. 25 \% odpovědí v dané obci). Zatímco nákupní spád Globusu je prostorově vymezen dálnicí D1 a hranicí okresu Vyškov, Olympia svojí „gravitační silou“ zasahuje více obcí v prstenci kolem Brna. Dlužno podotknout, že na severu města ojedinělý Globus, přes svoji výrazně užší specializaci převážně na potravinářské zboží (či díky ní?), stahuje také obyvatele obcí okresu Blansko, výjimkou není ani dojížd'ka ze Žd'árska a Svitavska.

Olympia si kromě dominantního jihu a jihozápadu podmanila také obce na východě aglomerace, kde při vyškovské dálnici D1 není umístěno žádné nákupní centrum či jiná dominantní velkoplošná prodejna. Boj o zákazníka tak Olympia a Globus svádí zejména na severovýchod od Brna, kde se odpovědi respondentů, a tedy i reálné rozhodování obyvatel „kam jet nakupovat na víkend“, překrývají. 
Za konkrétní zmínku stojí také jedno z nejznámějších nákupních center v České republice - Galerie Vaňkovka. Co se týče nákupního spádu návštěvníků z obcí v širším zázemí Brna, nemá Vaňkovka tak silnou pozici jako pro obyvatele v Brně bydlící, resp. pracující v blízkosti centra. Dokládá to i hodnota relativní návštěvnosti v tabulce 7.4 (podíl dotázaných, kteří uvedli, že pravidelně navštěvují dané nákupní centrum), která je nižší než v př́ípadě Olympie a Globusu.

\section{Porovnání faktorů ovlivňujících denní a nedenní dojížd'ku za maloobchodem}

Pro účel zjištění a verifikace relativní významnosti faktorů ovlivňujících variabilitu v dojižd'ce za nákupy do Brna jsme použili metodu logistické regrese. Výsledky zachycuje tabulka 7.5. Porovnání finálních regresních modelů pro obě závislé proměnné (tedy (i) nákupy základních potravin v Brně a (ii) návštěvnost obchodních center na okraji Brna) potvrdilo do značné míry naše výzkumné hypotézy. Můžeme říci, že v prípadě nákupů základních potravin je dominantním faktorem nákupů ve městě Brně denní dojížd'ka do zaměstnání v Brně (tzn. ti, kteří v Brně pracují nebo studují, zde i cestou nakoupí). Druhým nejvýznamnějším faktorem je potom blízkost místa bydliště k Brnu. Zlomovou se v tomto smyslu ukázala být hranice 15 kilometrů, resp. časové vzdálenosti 15 minut. Z obcí ležících v této dojížd'kové vzdálenosti jezdí za nákupy potravin do Brna zhruba polovina dotázaných. Se zvyšující se vzdáleností tento podíl již významně klesá.

Faktor velikosti obce, který fakticky předurčuje její občanskou vybavenost a nabídku obchodů a služeb, má za následek to, že z nejmenších obcí (do 200, resp. do 500 obyvatel) jezdí převážná většina obyvatel za nákupy do měst či větších, tzv. střediskových obcí ve svém okolí. Z hlediska dojížd'ky do Brna však nemá velikost obce takový význam jako faktor vzdálenosti. Ukázalo se také, že častěji v Brně nakupují mladí a lidé v produktivním věku (do 50 let) a lidé s vyšším dosaženým vzděláním, což je do značné míry způsobeno také tím, že právě tyto skupiny do Brna také dojižčěí za prací či studiem (téměř třetina všech dotázaných).

Pokud se podíváme na faktory ovlivňující variabilitu v nedenní dojižd'ce za obchodem, resp. v míře návštěvnosti obchodních center na okraji Brna, zjištujeme, že oslabuje vliv místa zaměstnání a také vliv vzdálenosti bydliště od Brna a naopak nabývají na významu faktory věku a vzdělání. Snižila se také celková míra predikce druhého regresního modelu, což znamená, že návštěvnost obchodních center je více ovlivněna dalšími faktory, které nebyly zahrnuty do analýzy (např. osobní motivace nakupování, preference v trávení volného času apod.). 
Tab. 7.5: Výsledky multinominální logistické regrese - faktory ovlivňující dojížd'ku za nákupy do Brna

\begin{tabular}{|c|c|c|c|c|c|}
\hline \multirow[t]{2}{*}{ Faktory } & \multirow[t]{2}{*}{ Závislé proměnné } & \multicolumn{2}{|c|}{ Nákupy základních potravin } & \multicolumn{2}{|c|}{$\begin{array}{l}\text { Návštěvy obchodních } \\
\text { center }\end{array}$} \\
\hline & & $\operatorname{Exp}(B)$ & Sig. & $\operatorname{Exp}(B)$ & Sig. \\
\hline Konstanta & & & 0,000 & & 0,000 \\
\hline \multirow{3}{*}{ Velikost obce } & do 200 obyvatel & 0,894 & 0,637 & 0,736 & 0,046 \\
\hline & 200-500 obyvatel & 0,840 & 0,030 & 0,732 & 0,010 \\
\hline & 501-1 000 obyvatel & 0,624 & 0,000 & 0,694 & 0,000 \\
\hline \multirow[t]{2}{*}{$\begin{array}{l}\text { Vzdálenost } \\
\text { od Brna }\end{array}$} & do $15 \mathrm{~km}$ & 0,156 & 0,000 & 0,610 & 0,000 \\
\hline & $15-30 \mathrm{~km}$ & 0,459 & 0,000 & 1,003 & 0,972 \\
\hline Práce v Brně & ne & 6,525 & 0,000 & 2,142 & 0,000 \\
\hline Pohlaví & muž & 0,963 & 0,602 & 1,171 & 0,011 \\
\hline \multirow[t]{3}{*}{ Věk } & 16-35 let & 0,358 & 0,000 & 0,107 & 0,000 \\
\hline & $36-50$ let & 0,484 & 0,000 & 0,167 & 0,000 \\
\hline & 51-65 let & 0,589 & 0,001 & 0,370 & 0,000 \\
\hline \multirow[t]{2}{*}{ Vzdělání } & VŠ & 0,412 & 0,000 & 0,378 & 0,000 \\
\hline & SŠ s maturitou & 0,602 & 0,000 & 0,513 & 0,000 \\
\hline \multicolumn{2}{|l|}{ R2 Nagelkerke } & \multicolumn{2}{|c|}{0,344} & \multicolumn{2}{|c|}{0,282} \\
\hline \multicolumn{2}{|l|}{ Predikce } & \multicolumn{2}{|c|}{$82 \%$} & \multicolumn{2}{|c|}{$76 \%$} \\
\hline
\end{tabular}

Zdroj: Vlastní šetření a výpočty. $N=6300$.

Pozn.: Referenční kategorie závislé proměnné: dojižd'ka za nákupy do Brna. Referenční kategorie nezávislých proměnných: velikost obce nad 1000 obyvatel, vzdálenost nad $30 \mathrm{~km}$, práce v Brně, věk 65+, vzdělání základní/vyučení.

\subsection{Shrnutí}

Výzkum, který byl realizován v obcích v zázemí Brna, přinesl řadu zajímavých výsledků. Vybrané výzkumné otázky měly rozkrýt charakter nákupního chování a nákupního spádu spotřebitelů v poměrně širokém zázemí města Brna. Shrňme si nyní nejdůležitější výsledky z provedených analýz.

Co se týče denní dojižd'ky za maloobchodem (tedy v prípadě základních potravin a dalších produktů denní spotřeby), jsou rozhodujícími faktory ovlivňujícími místo nákupu směr dojižd'ky do zaměstnání a blízkost místa bydliště $\mathrm{k}$ Brnu. ${ }^{26}$ Velikost obce, která prakticky předurčuje i její občanskou vybavenost a nabídku

26 Tento dílčí závěr se v obecné rovině shoduje s hodnocením intenzity dojižžd'ky do zaměstnání v zázemí Brna, jak ukazuje studie Krejčího a Touška (Krejčí, Toušek, 2004). 
obchodů a služeb, zapřičiňuje to, že z nejmenších obcí jezdí převážná většina obyvatel za nákupy do měst či větších (střediskových) obcí v okolí. Ve městě Brně nakupují také častěji mladí lidé, lidé v produktivním věku a lidé s vyšším dosaženým vzděláním. Jde o zjištění, která korespondují s dalšími výsledky výzkumů, které byly realizovány v rurálním (venkovském) a urbánním prostoru a jež se týkaly míry ovlivnění dojížd'ky za maloobchodem výstavbou nové velkoplošné maloobchodní sítě ve městech. McEachern a Warnaby (2006) řešili otázku dojížd'ky za nákupy potravin v rurálním prostoru západního Skotska a ukázalo se, že hranicí intenzivní dojížd'ky je vzdálenost 20 mil (32km). Kulke (1992) na příkladu nových nákupních center v bývalé NDR nebo Mitríková (2008) u nákupních center v Košicích a Prešově, stejně jako studie Szczyrby (2002) pro vybraný hypermarket v Olomouci dokládají, že hranice intenzivní dojížd'ky se posouvají v závislosti na charakteru osídlení a rozmístění relevantní maloobchodní konkurence. Navíc Smith a Sparks (2000) posouvají relace dojižd'ky za nákupy potravin a dalšího zboží mezi skotským venkovem a městy na aplikovanou úroveň celospolečensky závažného problému, a to zachování malých nezávislých prodejen v rurálním prostoru. Přesun těžiště nákupních vazeb mezi městem a venkovem směrem k městu, resp. jeho periferii potvrzují také Van Leeuwen a Rietveld (2011). Ti ve své studii, na příkladu pěti evropských zemí, zdưrazňují, že více než polovina nákupů domácností žijících ve městech nebo v jejich bezprostředním zázemí se ve městech také uskutečňuje.

Nákupní centra na okraji města Brna mají pro obyvatele obcí v zázemí daleko větší atraktivitu než pouze v nákupu základních potravin. $Z$ většiny šetřených obcí vyjiždí do nákupních center za nákupem (nejen potravin), službami a zábavou zhruba polovina obyvatel (respondentů). Pokud se tedy zaměříme na faktory ovlivňující variabilitu v nedenní dojížd'ce za obchodem, resp. v míře návštěvnosti obchodních center na okraji Brna, zjištujeme, že oslabuje vliv místa zaměstnání a také vliv vzdálenosti bydliště od Brna, a naopak nabývají na významu faktory věku a vzdělání. Snižuje se také celková míra predikce druhého regresního modelu, což znamená, že návštěvnost obchodních center je více ovlivněna dalšími faktory, které nebyly zahrnuty do regresní analýzy (např. osobní motivace nakupování, preference v trávení volného času apod.).

Do nákupních center jezdí nejčastěji mladší zákazníci ve věku do 35 let, často ekonomicky aktivní a zejména o víkendech. Nejnižší frekvenci mají senioři, přičemž jejich specifikem je převažující forma „čistého“ nakupování, tj. bez využití dalších služeb. Z hlediska základních poznatků nejde o nic překvapivého, nebot zvýšená spotřeba je spojena se zvýšením sociálního statusu. U teenagerů je typickým chováním i prosté prohlížení výkladů a zboží bez vlastního nákupu (také otázka finančního zázemí), přičemž nákupní centra se pro ně stávají místy, kde se mohou potulovat, setkávat s práteli, resp. být viděni svými kamarády (být „in“), 
což dokládají i studie Jarboea a McDaniela (1987), Kunce et al. (2010), Jacksona et al. (2011) či Spilkové (2012b).

Velká většina respondentů jezdí do nákupních center autem, zejména pak střední generace. Čím menší je obec a čím dále leží od Brna, tím častěji její obyvatelé využívají auto. Jde o logickou implikaci, ovšem je třeba si zároveň uvědomit, že charakter nákupních center téměř nepřipouští jinou variantu. Jsou budována především jako místa nákupů pro motorizované zákazníky, což potvrzuje většina podobně zaměřených výzkumů (např. Brown, 1991; Kulke, 1992; Marjanen, 1995; Findlay et al., 2001; Severin et al., 2001; Szczyrba, 2002; Mitríková, 2008; Wagner, Rudolph, 2010 a řada dalších).

Nákup oděvů, oděvních doplňků a obuvi tvoří více než čtvrtinu celkového času stráveného v nákupním centru. Pro seniory jsou nejčastějším nákupem potraviny, príp. také oděvy a obuv. Rozdíly jsou také mezi pohlavími, ženy jsou obecně více citlivé $k$ čistotě daného centra a jeho okolí a mají z nakupování větší „požitek", na což mimo jiné poukazují ve svých studiích také Cleveland et al. (2003) či Jackson et al. (2011). Co se týče sortimentu, ženy inklinují právě k výše uvedeným oděvům, obuvi a doplňkům, muži se více orientují na sportovní potřeby, zábavu a trávení volného času.

Delší dobu v nákupních centrech stráví zákazníci mladší a střední generace, pro které jsou moderní nákupní centra s množstvím obchodních lákadel místem velmi atraktivním, nejen co se týče nakupování, což dokládá ve své studii také Underhill (2004), Teller (2008) nebo Spilková (2012a). Právě Spilková (2012a, 2012b) identifikovala v pražských nákupních centrech generaci takzvaných „, mall junkies“, tedy mladých lidí závislých na pobytu v nákupním centru bez potřeby vlastního nákupu (více viz také Underhill, 2004).

Nejvyšší útratu udávají lidé v produktivním věku, přičemž vzdělání, velikost obce ani vzdálenost od Brna nehrají významnější roli. Největším motivačním faktorem pro návštěvu nákupního centra je širší sortiment zboží a možnost většího výběru, zdánlivě i úspora peněz (ovšem pouze v přepočtu na jednotku, ve skutečnosti zákazníci dělají větší nákupy, než původně zamýšleli). Reklama a inzerce ovlivňují intenzitu nákupů a nákupní zvyklosti u poloviny dotázaných, přičemž více působí na ženy, resp. osoby v důchodovém věku, což opět potvrzují některé výzkumy (např. Marjanen, 1995; Jackson et al., 2011).

Centra českých měst (včetně Brna) jsou vystavena postupnému procesu komercializace (Kolibová, 1999; Sýkora, 2001; Ilnicki, 2009; Kunc et al., 2012a), ale i gentrifikace, jehož jedním z důsledků je vytlačování prodejen potravin z centra města. Tuto skutečnost potvrzují také Mulíček, Osman (2009), kteří uvádějí, že prodejní plocha potravinářských prodejen v centru města Brna (nejen zde, ale i v jiných městských částech) neustále klesá. $V$ této souvislosti Cummins a Macintyre (1999), Zenk (2005) nebo Križan et al. (2009) poukazují, na príkladu 
decentralizace městské maloobchodní sítě a úbytku prodejen potravin v urbánním prostředí, na vznik tzv. potravinových poušt ${ }^{27}$. Výše uvedeným skutečnostem odpovídá přesun těžiště nákupů potravin do sídlištních zón a na městskou periferii, kde jsou lokalizovány supermarkety a hypermarkety, často jako součást nákupních center. Sledujeme-li pohyby obyvatel města v denních urbánních systémech, pak zde vystává vcelku logická otázka, jak se bude dál vyvíjet potravinářský sektor $v$ Brně. Patrně bude současný stav ještě více korigován $v$ neprospěch městského centra, což zvýší zatížení periferních lokalizací.

Následnou otázkou je, jak se bude vyvíjet sít potravinářských prodejen v blízkém zázemí Brna, když již dnes pozorujeme realizaci nadpoloviční většiny potravinářských nákupů $v$ síti prodejen potravin v Brně. Navíc již téměř polovina obyvatel zájmového území nakupuje nedenně potraviny v nákupních centrech (viz také Kunc et al., 2012b). Pokud by tato sít potravinářských prodejen ve venkovských obcích v zázemí Brna měla být dále redukována (jde o obecný trend), pak by se jistě promítla zvýšená frekvence maloobchodních interakcí v rámci denního urbánního systému města Brna. Potravinové pouště by tak vznikaly, resp. již vznikají, i ve venkovském prostoru. Tyto závěry potvrzují dlouhodobé výzkumy z jiných modelových měst, např. z finského Turku (Marjanen, 1995), amerického Orlanda, kanadského Edmontonu či norského Osla (Severin et al., 2001), byt maloobchodní interakce a nákupní chování se, zejména v př́padě obyvatel aglomerace Turku, změnily mezi sledovanými roky méně, než se původně předpokládalo. Crosby et al. (2005) uvádějí ve své studii podobný př́klad z anglického Readingu, kde výstavba nákupního centra The Oracle znamenala významné přeskupení maloobchodních vazeb mezi centrem města a okrajovými částmi. Zde je ovšem nutné poznamenat, že změna frekvence maloobchodních interakcí závisí na celé řadě faktorů, jimiž jsou rozdílné sídelní systémy, regulace vnitřního trhu a pak také kontinuita změn nákupního chování, která byla v zemích s vyspělou tržní ekonomikou značně odlišná nežli v zemích postsocialistických, které byly skokově vystaveny novým tržním (globalizačním) mechanismům. službám i specifickým potravinovým provozovnám. Spotřebitelé jsou limitováni užším sortimentem, vyššími cenami, nevhodnou otevírací dobou apod. (více viz např. Zenk et al., 2005; Shaw, 2006). 


\section{Brněnská aglomerace: spádovost za službami a její vývoj na př́kladě obslužných procesů v zázemí Brna}

\subsection{Metodika výzkumu}

Vztahy mezi místem bydliště a místem maloobchodu a služeb patří mezi základní socioekonomické vztahy a dojižd'ku za maloobchodem a službami můžeme považovat za jeden ze základních regionotvorných procesů (viz např. Hampl et al., 1978). Vedle dojížd'ky do škol, která je pravidelným pohybem, se jedná v našich podmínkách o nepravidelné pohyby obyvatelstva (např. Anděl, Bičík, 1980) a pro jejich analýzu je omezujícím faktorem otázka datové základny. Nedostatek vhodných údajů o dojížd'ce za nákupy a službami (neexistuje jejich centrální zjištování) však nedovoluje detailní poznání těchto procesů mobility obyvatelstva.

Metodicky anketní šetření navazovalo na obdobná dřive uskutečněná šetření mobility obyvatelstva za službami, provedená jednak na přelomu 70. a 80 . let minulého století Geografickým ústavem ČSAV na území celého Československa (viz Maryáš, 1987, 1988), jednak rozsahem omezenější šetření prováděné v letech 2004-2006 na území Moravy Univerzitou Palackého v Olomouci a Masarykovou univerzitou. Obdobně jako ve zmíněných šetřeních byly potřebné údaje zjištovány korespondenční metodou - rozesíláním dotazníků na obecní úřady, formou cílených dotazů pro zástupce veřejné správy (primárně starostové obcí). Otázky byly sestaveny tak, aby mohly být provedeny komparativní analýzy se zmíněnými šetřeními (viz tabulka 8.1).

Tab. 8.1: Otázky dotazníkového šetření

\begin{tabular}{|l|}
\hline Denní nákupy potravin \\
\hline Nákupy běžného textilu a obuvi \\
\hline Běžné služby (holičství, kadeřnictví, čistírna aj.) \\
\hline Návštěva lékárny \\
\hline Nákupy průmyslového zboží (elektrospotřebiče) \\
\hline Speciální služby (např. fotograf, oprava hodin, šití šatů aj.) \\
\hline Nákupy knih a CD \\
\hline Nákupy nábytku \\
\hline Nákupy speciálního výběrového zboží (klenoty, auto moto aj.) \\
\hline
\end{tabular}

Zdroj: Vlastní šetření. 
Šetření bylo provedeno přes soustavu obecních úřadů, kdy starostové úřadů, resp. tajemníci, byli dotazováni na hlavní, vedlejší a výjimečné cíle obyvatel obce v uvedených procesech. Územní rozsah byl zvolen tak, aby pokrýval Jihomoravský kraj a okresy Kraje Vysočina přiléhající k okresu Brno-venkov. Šetření probíhalo v rámci zadaných diplomových prací na území okresů Brno-venkov (Vepřek, 2012), Blansko (Bračok, 2011), Břeclav (Laštůvková, 2012), Hodonín (Laštůvková, 2012), Třebíč (Žák, 2012), Vyškov (Bartáková, 2010), Znojmo (Vacek, 2010; Potůčková, 2012) a Ždár nad Sázavou (Jirásková, 2012).

Po analýzách obslužných procesů byly pro vymezení sfér obslužné spádovosti vybrány ty, které frekvencí využití reprezentují daný hierarchický stupeň. Zde jsme se snažili v co nejvyšší míře navázat na předchozí šetření a hodnotili jsme pouze nákupy textilu a obuvi, průmyslového zboží (elektrospotřebičů), léků, knih, nábytku, a návštěvy běžných a speciálních služeb (nákupy potravin a speciálního výběrového zboží nebyly hodnoceny).

Výběr obslužných středisek vycházel do značné míry z pưvodní metodiky výběru středisek obslužné spádovosti Československa (Maryáš, 1988), která po analýzách vzdáleností, do které se uskutečňují cesty za nákupy a službami a podílu obcí uváděných jako hlavní cíle dojižd'ky v obslužných procesech, stanovila kritéria pro určení obslužných středisek na základě regionální působnosti. Za postačující byla zvolena podmínka, aby obec byla uvedena jako jednoznačný (hlavní) cíl dojížd'ky alespoň pro jednu obec ve výše analyzovaných obslužných procesech.

Rovněž při vymezování sfér vlivu obslužných středisek jsme vycházeli z původní metodiky (Maryáš, 1988). Odpovědi z anketního šetření byly hodnoceny následovně: vykazované směry spádu byly kategorizovány podle intenzity spádu do tří typů - převážný spád 10 bodů, částečný 5 bodů a výjimečný 1 bod. Pro jednotlivé obce byla každému cíli $i$, který byl obcí vykazován v daném obslužném procesu $j$, přiřazena hodnota $v_{i j}$, která určuje relativní význam cíle $i$ pro vykazující obec $v$ tomto obslužném procesu:

$$
v_{i j}=\frac{T_{i j}}{P C_{i j} \cdot P T_{i j}} \cdot 100,
$$

kde: $T_{i j}$ - bodová hodnota typu spádu do cíle $i$ v obslužném procesu $j$, $P C_{i j}$ - počet cílů v tomto typu,

$P T_{i j}$ - součet bodových hodnot všech typů intenzity spádu uváděných obcí v obslužném procesu $j$.

$\checkmark$ každé obci byl součet hodnot $v_{i j}$ roven $100 \%$ pro každý obslužný proces $j$. Každému obslužnému procesu byl dále přiřazen koeficient $k_{j}$ podle významu, resp. frekvence využívání. Celkový relativní význam $c v_{i}$ cíle $i$ pro danou obec za všechny hodnocené obslužné procesy je potom roven: 


$$
c v_{i}=\frac{\sum_{j} v_{i j} * k_{j}}{\sum_{i} \sum_{j} v_{i j} * k_{j}} * 100
$$

Opět platí, že v každé obci $\sum c v_{i}=100 \%$.

Při vymezování sfér vlivu obslužných středisek bylo hlavním problémem ohodnocení jednotlivých obslužných procesů z hlediska frekvence využívání a tím i určité vyjádření důležitosti procesu pro uspokojování potřeb obyvatelstva. Vycházeli jsme především z počtu uváděných cílů, při předpokladu, že nejvíce cílových obcí je vykazováno u nejčastěji využívaných zařízení občanské vybavenosti, a tedy u nejvýznamnějších, resp. současně nejfrekventovanějších, obslužných procesů (viz Maryáš, 1988).

Obslužné procesy byly kategorizovány podle intenzity spádu, a to na základě analýzy hlavních cílů, tj. cílů uváděných jako cíle převážných nákupů, resp. služeb. Každému obslužnému procesu byl stanoven koeficient podle poměrů počtů hlavních cílů uvedených v daných obslužných procesech na území vybraných okresů jižní Moravy a počtu cílů v dojižd'ce za nákupy knih, kde byl spolu s nákupy nábytku nejmenší počet hlavních cílů ze zjišttovaných základních obslužných procesů. Byly rozlišeny čtyři podskupiny základních obslužných procesů a pro další hodnocení byl těmto podskupinám přiřazen rozdílný koeficient.

Poměry byly následující:

- nákupy knih : nákupy nábytku : nákupy běžného průmyslového zboží : speciální služby : nákupy textilu a obuvi : nákupy léků : běžné služby = $1: 1: 1,5: 1,6: 1,6: 2,1: 3,2$.

Koeficienty byly potom stanoveny takto:

- koeficient 1 - nákupy knih, nábytku,

- koeficient 1,5 - nákupy textilu a obuvi, běžného průmyslového zboží, speciální služby,

- koeficient 2 - nákupy léků,

- koeficient 3 - běžné služby.

K vybraným střediskům byly ostatní obce přiřazeny na základě převažujícího spádu - kdy celkový relativní význam nejsilnějšího střediska nedosahoval více než dvě třetiny hodnoty celkového relativního významu prvního nejsilnějšího střediska. Ostatní obce, které nevykazovaly dostatečně významnou spádovitost k určitému středisku, byly považovány za oscilační. 


\subsection{Komparace základního obslužného regionu Brna v letech 1979 a 2010-2012}

Pokud srovnáme současný územní rozsah zázemí Brna na úrovni základního obslužného regionu se situací v roce 1979 (viz obrázky 8.1 a 8.2), Ize konstatovat, že vzrostl vliv Brna na úkor některých okolních středisek v okrese Brno-venkov i okresních měst (Blansko). Tento nárůst vlivu se projevuje především nárůstem oscilačních obcí, které uvádějí jako rovnocenný cíl spádu za službami vedle svého střediska rovněž Brno. Klasická střediska v zázemí Brna (Ivančice, Pohořelice, Rosice, Tišnov a Židlochovice) si většinou udržela svá obslužná zázemí, i když v oblastech dobře dopravně napojených na Brno část svého zázemí ztrácí - především se to týká Rosic a Velké Bíteše. Nicméně posílením obslužné vybavenosti měst (viz např. Szczyrba et al., 2005) došlo i k nárůstu obslužných regionů některých $z$ těchto středisek, zvláště Pohořelic a Ivančic. Ten bude vyžadovat ještě podrobné výzkumy provedené na vzorku obyvatelstva v zázemí jmenovaných středisek.

\section{Obr. 8.1: Spádovost za službami v zázemí Brna v roce 1979}

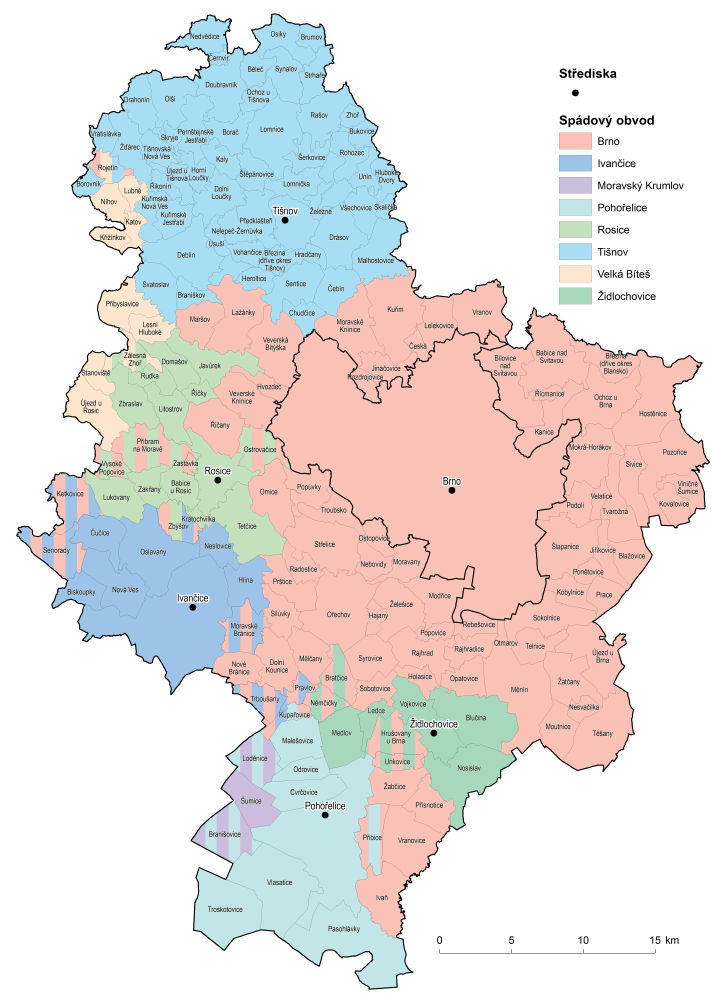

Zdroj: FSÚ (1977); vlastní šetření. 
Na druhé straně však došlo k rozvoji obslužných funkcí měst v suburbánní zóně, často podpořených lokalizací velkoformátových prodejen, což se projevilo rozvojem nových dosud neetablovaných obslužných středisek. Odpovídá to obecným teoriím o nárůstu oboustranných kontaktů mezi střediskem a zázemím v postindustriální etapě rozvoje (viz např. Hampl, 2005). V nejbližší suburbánní zóně Brna patří mezi tato vznikající střediska Kuřim a Modřice a výhledově i Šlapanice.

Porovnávali jsme dále počet hlavních cílů (viz tabulka 8.2) a dojížd'kovou vzdálenost v jednotlivých obslužných procesech (viz tabulka 8.3). Počet hlavních cílů byl zjištován na celém zkoumaném území - tady Jihomoravském kraji a okresech Třebíč a Žd'ár nad Sázavou, dojížd'ková vzdálenost (vzdušná vzdálenost) jen na vybraných modelových územích. Převzali jsme ji ze zadaných diplomových prací za okresy Břeclav, Hodonín, Třebíč, Vyškov a východní část okresu Znojmo, celkem se jednalo o 452 obcí. Výsledná hodnota znázorněná v tabulce 8.3 je váženým průměrem devadesátých percentilů ve jmenovaných územích.

\section{Obr. 8.2: Spádovost za službami v zázemí Brna v letech 2010-2012}

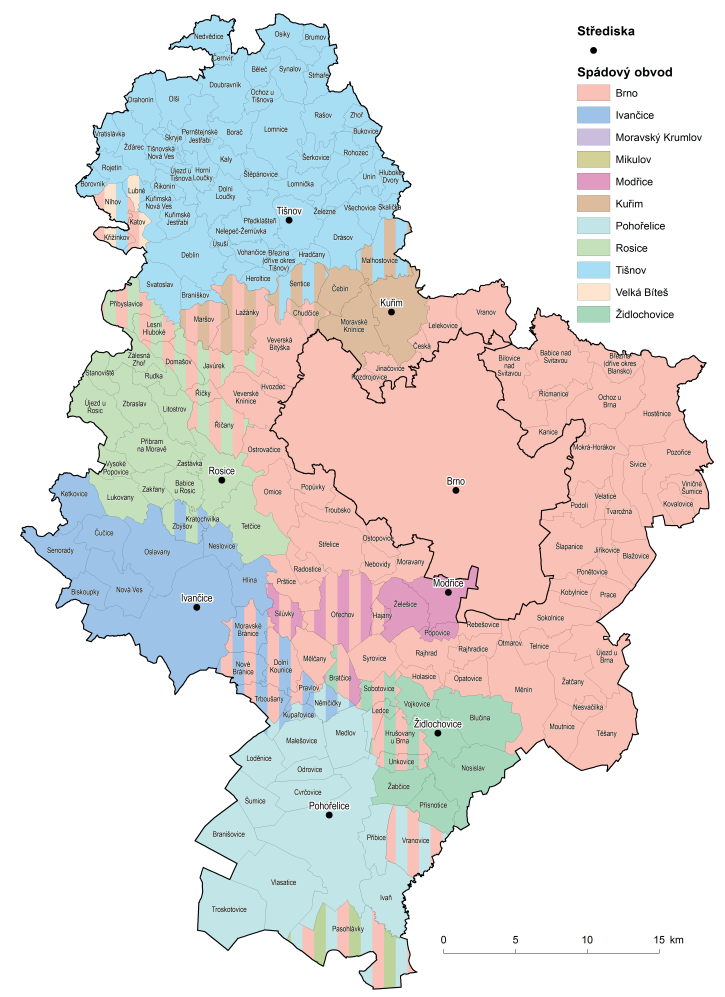

Zdroj: vlastní šetření. 
Přes masivní nárůst služeb po roce 1989 nedošlo k poklesu dojížd'kové vzdálenosti v jednotlivých obslužných procesech. Změnila se ale hierarchie jednotlivých obslužných procesů za službami - zatímco výskyt speciálních služeb byl na konci 70. let etalonem pro typické městské obslužné středisko, a tedy pro mikroregionální úroveň (viz Maryáš, 1988), v současnosti se tyto služby přibližily zákazníkovi a patří do skupiny procesů mezi nadlokální a mikroregionální hierarchickou úrovní (viz tabulka 8.2). Obdobně se změnila i pozice nákupů léků. Nárůst motorismu v posledním dvacetiletí vedl ke změně hierarchické úrovně nákupních procesů vázaných na automobily ( $v$ našem dotazníku byly obsaženy v nákupech speciálního výběrového zboží), které byly ještě v minulém století považovány za oblužný proces vyšší než mikroregionální úrovně (tamtéž).

Tab. 8.2: Poměry počtu hlavních cílů v jednotlivých obslužných procesech $\mathrm{k}$ počtu hlavních cílů $v$ nákupech speciálního výběrového zboží

\begin{tabular}{|l|c|c|}
\hline Nákupy speciálního zboží & ČSR 1979 & Jižní Morava 2010-2012 \\
\hline Běžné služby & 5,8 & 3,0 \\
\hline Nákupy léků & 2,6 & 1,9 \\
\hline Nákupy běžného textilu a obuvi & 5,2 & 1,5 \\
\hline Nákupy běžného prům. zboží & 4,5 & 1,4 \\
\hline Speciální služby & 1,5 & 1,4 \\
\hline Nákupy knih a CD & 1,9 & 0,9 \\
\hline Nákupy nábytku & 1,6 & 0,9 \\
\hline Nákupy spec. výběrového zboží & 1,0 & 1,0 \\
\hline
\end{tabular}

Zdroj: Maryáš, 1992; Bartáková, 2010; Bračok, 2011; Jirásková, 2012; Laštůvková, 2012; Potůčková, 2012; Vacek, 2010; Vepřek, 2012; Žák, 2012; vlastní výpočty.

Nejvýznamnější změny ovšem přinesly koncentrační tendence v maloobchodě a nový fenomén hypermarketů a nákupních center. Výsledkem byl nárůst dojižd'kové vzdálenosti do hlavních cílů v některých obslužných procesech, především v dojižd'ce za nákupy průmyslového zboží a za nákupy textilu a obuvi.

Došlo rovněž k nárůstu vzdálenosti, na které jsou relativně uzavřeny obslužné procesy - měřeno $90 \%$ vzdáleností, do které se uskuteční veškeré cesty za nákupy a službami - a to prakticky u všech obslužných procesů, kromě již zmíněné dojižd'ky za speciálními službami a nákupy lékủ. Relativní uzavřenost se zvýšila i u denních nákupů potravin. 


\subsection{Shrnutí}

Srovnání současných výsledků s výsledky získanými na konci 70. let dovoluje formulovat určité závěry. Oproti stavu před 30 lety můžeme pozorovat následující vývojové tendence:

- růst důležitosti regionálních metropolí - výsledkem je nárůst regionálního dosahu obslužného zázemí Brna;

- zvyšování obousměrných kontaktů mezi metropolí a zázemím, kdy výsledkem je rozvoj nových dosud neetablovaných obslužných středisek v nejbližší suburbánní zóně Brna;

- masivní nárůst služeb, kdy výsledkem je změna hierarchie některých obslužných procesů - dojížd'ky za speciálními službami a dojížd'ky za nákupy léků;

- nárůst motorismu, jehož výsledkem je pokles hierarchické úrovně nákupních procesů vázaných na automobily (nákupy speciálního výběrového zboží);

- koncentrační tendence $v$ maloobchodě a nový fenomén hypermarketů a nákupních center - výsledkem je nárůst dojížd'kové vzdálenosti v některých obslužných procesech, především za nákupy průmyslového zboží a za nákupy textilu a obuvi, a nárůst vzdálenosti, na které jsou relativně uzavřeny hodnocené obslužné procesy.

Tab. 8.3: Vzdálenost v km, do které se uskutečnilo $90 \%$ cest za nákupy a službami

\begin{tabular}{|l|c|c|c|c|}
\hline \multirow{2}{*}{ Formy nákupů } & \multicolumn{2}{|c|}{ ČSR 1979 } & \multicolumn{2}{c|}{$\begin{array}{c}\text { Modelová území } \\
\text { 2010-2012 }\end{array}$} \\
\cline { 2 - 5 } & hlavní cíle & $\begin{array}{c}\text { všechny } \\
\text { cíle }\end{array}$ & hlavní cíle & $\begin{array}{c}\text { všechny } \\
\text { cíle }\end{array}$ \\
\hline Denní nákupy potravin & 0 & 11 & 3 & 15 \\
\hline Nákupy běžného textilu a obuvi & 10 & 18 & 16 & 31 \\
\hline Běžné služby & 10 & 14 & 12 & 18 \\
\hline Nákupy léků & 11 & 16 & 11 & 17 \\
\hline Nákupy běžného prům. zboží & 11 & 20 & 18 & 35 \\
\hline Speciální služby & 15 & 20 & 15 & 21 \\
\hline Nákupy knih a CD & 15 & 21 & 16 & 36 \\
\hline Nákupy nábytku & 15 & 23 & 22 & 36 \\
\hline Nákupy spec. výběrového zboží & 20 & 34 & 20 & 36 \\
\hline
\end{tabular}

Zdroj: Maryáš, 1988; Bartáková, 2010; Jirásková, 2012; Laštůvková, 2012; Potůčková, 2012; Vacek, 2010; Žák, 2012; vlastní výpočty. 



\section{Brněnská aglomerace: denní i nedenní dojížd'ka za maloobchodem, nákupní spád a nákupní chování ve vnitřním Brně}

\subsection{Metodika výzkumu}

Pro účely výzkumu ve vnitřním městě jsme zvolili dotazování respondentů na ulici, což znamenalo vzorek složený z rezidentů, ale i osob s trvalým bydlištěm v jiné lokalitě, kteří se $v$ denním urbánním systému města pohybují v souvislosti s prací, studiem, využíváním služeb apod. Místem dotazování se staly prostorové jednotky - urbanistické obvody města Brna - které byly agregovány podle morfogenetické podobnosti (Mulíček, 2007) v rámci městské struktury (poloha ve městě vůči historickému jádru, typ zástavby apod.) v relativně homogenní celky. Tyto celky je možné ztotožnit s katastrálními územími v rámci Brna, které je pro zjednodušení možné označit také za městské čtvrti. Na této úrovni probíhaly následné analýzy a hodnocení.

Dotazníkové šetření bylo realizováno formou standardizovaných řizených rozhovorů pomocí vyškolených tazatelů (studentů Masarykovy univerzity v Brně) na podzim 2011 a na jaře 2012. Výběrový soubor obsáhl celkem 1600 respondentů starších 15 let trvale žijících v Brně ( $k$ 1. 1. 2012 mělo druhé největší město České republiky 379 tis. obyvatel). Výběr dotazovaných měl podobu dvoustupňového kvótního výběru, kdy byly v první fázi nejdříve zvoleny počty respondentů pro agregované urbanistické obvody proporcionálně $k$ jejich celkové populaci $v$ rozmezí 335 do 25 tisíc. Počet respondentů se dle velikosti městské čtvrti pohyboval v rozpětí od 15 do 100 . Ve druhé fázi byli respondenti vybíráni na základě kvótního výběru dle základních demografických znaků (pohlaví, věk) proporcionálně $k$ průměru populace města Brna. Ve výzkumném vzorku jsme záměrně snížili podíly v nejmladší a nejstarší věkové kategorii ve srovnání s podílem populace Brna v daných kategoriích. Na druhé straně jsou respondenti ve středním věku reprezentující největší kupní sílu ve vztahu k nakupování zastoupeni podílem vyšším (viz tabulka 9.1). 
Tab. 9.1: Struktura výzkumného vzorku

\begin{tabular}{|l|l|c|c|}
\hline \multirow{2}{*}{ Kategorie } & Výzkumný vzorek (\%) & Populace Brna (\%) \\
\hline \multirow{2}{*}{ Vohlaví } & muži & 42 & 48 \\
\cline { 2 - 4 } & ženy & 58 & 52 \\
\hline & $0-14$ & - nezahrnuti & 14 \\
\hline & $15-19$ & 2 & 4 \\
\hline & $20-29$ & 27 & 13 \\
\hline & $30-49$ & 45 & 30 \\
\hline & $50-59$ & 14 & 13 \\
\hline & 60 a více & 12 & 18 \\
\hline & základní & 5 & 30 \\
\hline & střední bez maturity & 20 & 34 \\
\hline & střední s maturitou & 45 & 18 \\
\hline
\end{tabular}

Zdroj: Šetření ve vnitřním Brně, podzim 2011 a jaro 2012.

Základní otázky šetření se zaměřily na místo nákupů a nákupní spád v členění „denní nákupy, víkendové/týdenní nákupy a specializované/nepravidelné nákupy", způsob dopravy a časovou vzdálenost, frekvenci nákupů. Dále jsme se respondentů ptali, zda postrádají ve městě určitý typ prodejny a zda vnímají změny ve struktuře a nabídce maloobchodu $v$ posledních letech $\mathrm{k}$ dobrému či horšímu. V poslední části dotazníku byly otázky orientovány na návštěvu nákupních center $v$ Brně, kde jsme zkoumali motivační faktory $k$ nákupům $v$ nákupních centrech, způsob přepravy, průměrný strávený čas v centru a průměrnou výši útraty v centru. To vše v kontextu základní demografické struktury (pohlaví, věk, vzdělání, počet členů domácnosti) a místa bydliště a pracoviště.

Cílem výzkumu bylo ověřit následující hypotézy:

- Velká nákupní centra a hypermarkety výrazně dominují z hlediska podílu na objemu realizovaných nákupů nad menšími maloobchodními jednotkami.

- Nákupní spád a nákupní chování lidí jsou významně ovlivňovány demografickými (věk) a socioekonomickými (ekonomická aktivita, příjem) charakteristikami jedinců.

- Percepce rozšiřování sítě maloobchodních prodejen v postsocialistických městech (zde reprezentovaných Brnem) a vývoj nabídky sortimentu $\checkmark$ průběhu posledních let vykazuje významně pozitivní hodnoty. 


\subsection{Hlavní výsledky výzkumu}

Frekvenci nákupů nejen ve vnitřním městě je možno jednoduše členit na tři základní typy: denní nákupy, týdenní (víkendové) nákupy a nepravidelné (specializované nákupy). U pravidelných denních nákupů převažuje potravinářské zboží a sortiment osobní potřeby v menším objemu. Víkendové či týdenní nákupy jsou zaměřeny na potravinářské i smíšené zboží (drogerie, domácí potřeby apod.) ve větším objemu nákupu. Nepravidelné nákupy zahrnují široký sortiment spotřebního zboží primárně nepotravinářského charakteru, jako jsou oděvy, obuv, elektronika, nábytek, kuchyňské potřeby, hračky, knihy apod. Toto rozdělení je na úvod pouze orientační, podrobněji dále.

Dle tří uvedených frekvenčních typů nákupů Ize nákupní spád obyvatel města Brna členit do pěti odlišných prostorových lokací:

- v místě bydliště a okolí (okolí je vymezeno hranicí příslušné městské čtvrti);

- v centru Brna (zahrnuje historické jádro a území okolo hlavního vlakového nádraží, kde leží obchodní dům Tesco a nákupní centrum Galerie Vaňkovka);

- $v$ nákupních centrech na okraji Brna (zahrnuje nákupní centra: Globus, Olympia, Avion Shopping Park, Futurum a Campus Square);

- jinde v Brně (území s maloobchodními jednotkami mimo tři výše uvedené lokace);

- jinde mimo Brno (území mimo administrativní hranice města).

Obr. 9.1: Místo realizace nákupů v členění dle tří základních frekvenčních typů nákupů

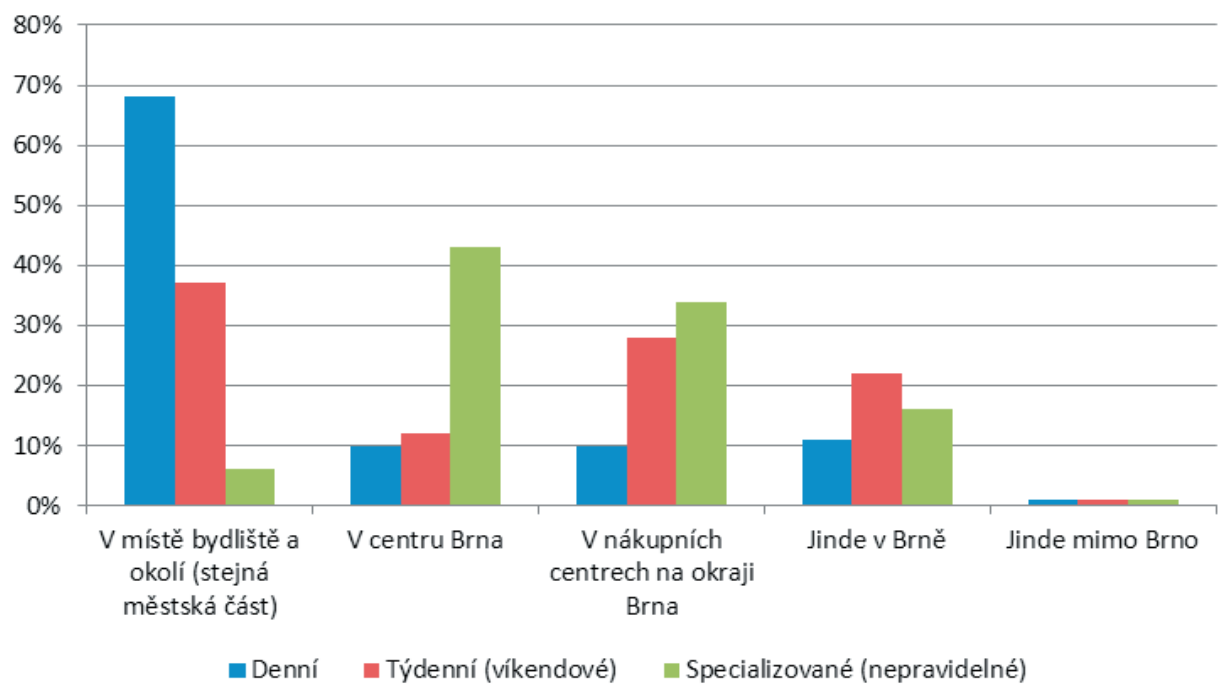

Zdroj: Šetření ve vnitřním Brně, podzim 2011 a jaro 2012. 
Jak dokládají obrázky 9.1 a 9.2, denní nákupy se dle předpokladu s velkou převahou (68 \% odpovědí) uskutečňují zejména v místě bydliště a okolí. Konkrétně se $v$ Brně jedná jednak o městské čtvrti s velkým počtem obyvatel a dobrou maloobchodní vybaveností - Královo Pole, Veveří, Žabovřesky, Židenice, Pisárky a velké sídlištní komplexy Bystrc, Bohunice, Starý Lískovec, Nový Lískovec, Lesná, Líšeň či Slatina, ale i populačně malá předměstí jako Tuřany, Chrlice či Žebětín, kde místní lidé preferují malý obchod, př́p. samoobsluhu.

$\checkmark$ centru Brna nakupují potraviny nejvíce obyvatelé centra samotného a městských čtvrtí ležících v jeho blízkosti: Trnitá, Komárov, Stránice, ale i ze vzdálených periferií Ivanovice a Dvorska. Zde se místo nákupu spojuje s místem pracoviště. Nákupní centra k denním nákupům preferují pouze obyvatelé severních předměstí Mokrá Hora, Útěchov, Ořešín či Ivanovice (vliv hypermarketu Globus, který je vzhledem ke své velikosti a uspořádáním mnoha menších obchodů v nákupní pasáži pod jednou střechou možné považovat za nákupní centrum) a jižních předměstí Dolní Heršpice, Horní Heršpice, Přížrenice a Holásky, kde se projevuje velmi silná koncentrace tří nákupních center Futurum, Avion Shopping Park a Olympia. Obyvatelé ostatních čtvrtí uskutečňují denní nákupy spíše v jiných městských čtvrtích, než je jejich bydliště. Jednotlivé městské čtvrti a lokalizaci nákupních center a hypermarketů Ize konfrontovat na obrázku 9.4.

Místa realizace týdenních (víkendových) nákupů jsou v prostoru vnitřního Brna daleko více vyrovnané (viz obrázek 9.3). Nejvýznamnější část lidí (37 \% odpovědí) nakupuje poněkud překvapivě opět (podobně jako u denních nákupư) v místě bydliště a okolí. To dokazuje, že obyvatelé řady městských čtvrtí využívají stále širší nabídky různých typů maloobchodních konceptů (samoobsluha, supermarket, hypermarket, diskont a další) v blízkosti svého bydliště $k$ větším pravidelným nákupům. Zde se ovšem již také projevuje stále rostoucí význam nákupních center na okraji města ( $28 \%)$.

Týdenní nákupy v místě bydliště a okolí upřednostňují zejména obyvatelé městských čtvrtí Královo Pole a Ponavy - také vliv lokalizace nákupního centra Královo Pole ve stejnojmenné čtvrti, Zábrdovic - hustá zástavba a velmi dobrá maloobchodní vybavenost a sídlišt Starý Lískovec a Vinohrady - také s dostatečnou koncentrací obchodů. Týdenní nákupy v nákupních centrech jsou typické pro severní (Ivanovice, Mokrá Hora) a jižní předměstí (Horní Heršpice, Dolní Heršpice, Přizřenice a Chrlice), kde již výše zmíněná nákupní centra vytvářejí velmi silné nákupní ostrovy (daleko výraznější než v případě denních nákupů).

Týdenní nákupy mimo své bydliště a okolí volí obyvatelé městských čtvrtí ležících především ve východní části města (Obřany, Maloměřice, Husovice), kde není lokalizováno žádné nákupní centrum ani hypermarket. $\mathrm{S}$ trochou nadsázky je možné hovořit o maloobchodně poddimenzované východní části Brna. 
Obr. 9.2: Místo realizace denních nákupů dle jednotlivých městských čtvrtí ve vazbě na místo bydliště respondentů

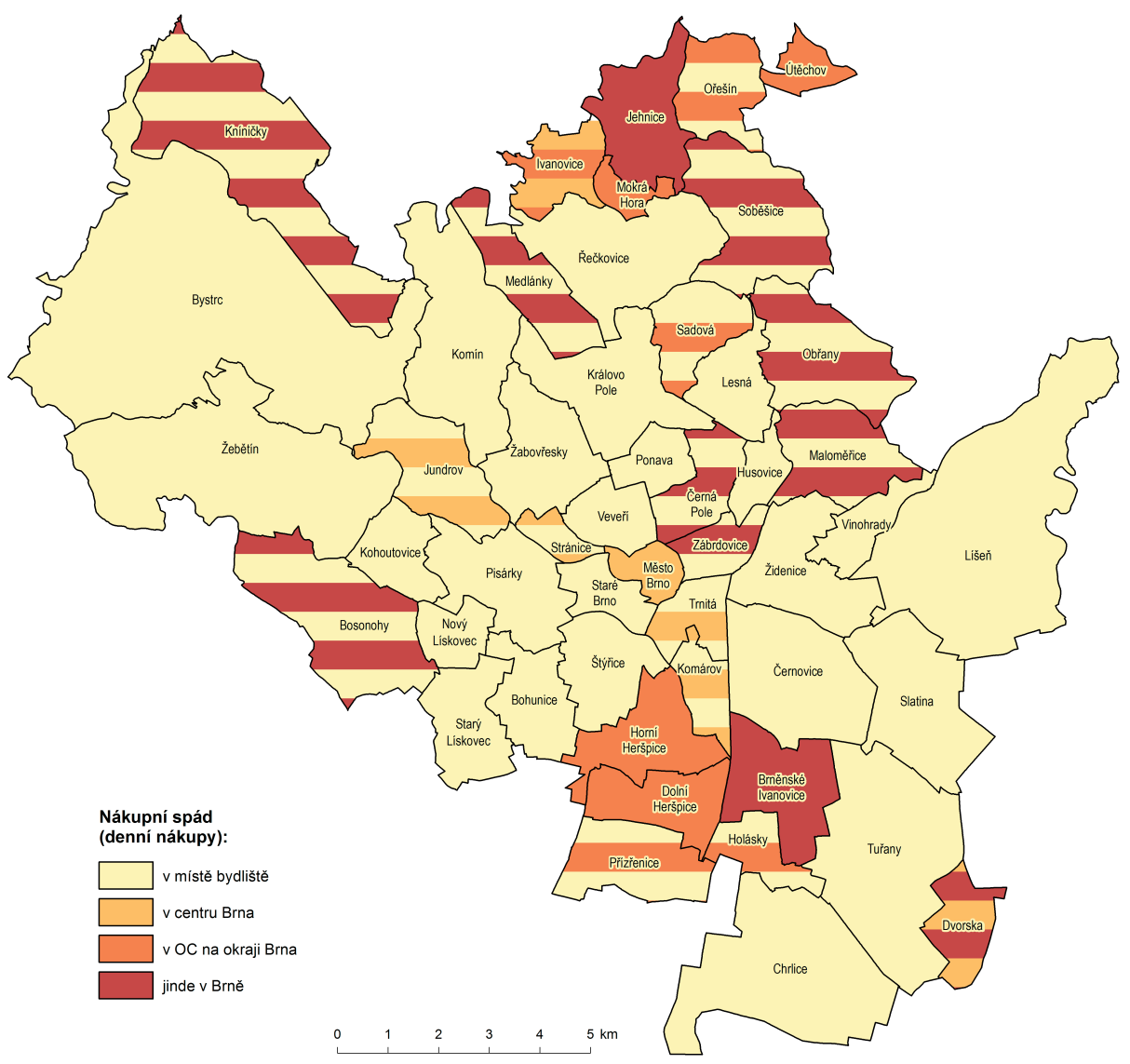

Zdroj: Šetření ve vnitřním Brně, podzim 2011 a jaro 2012.

Obdobně odpověděli také respondenti severního řídce zalidněného předměstí Jehnice a centrálních Pisárek, kde také chybí velkoformátové prodejny, ale mají velmi dobré dopravní spojení s okolními, lépe vybavenými čtvrtěmi. Centrum města není pro spád za týdenními nákupy preferovanou lokací. 
Obr. 9.3: Místo realizace týdenních nákupů dle jednotlivých městských čtvrtí ve vazbě na místo bydliště respondentů

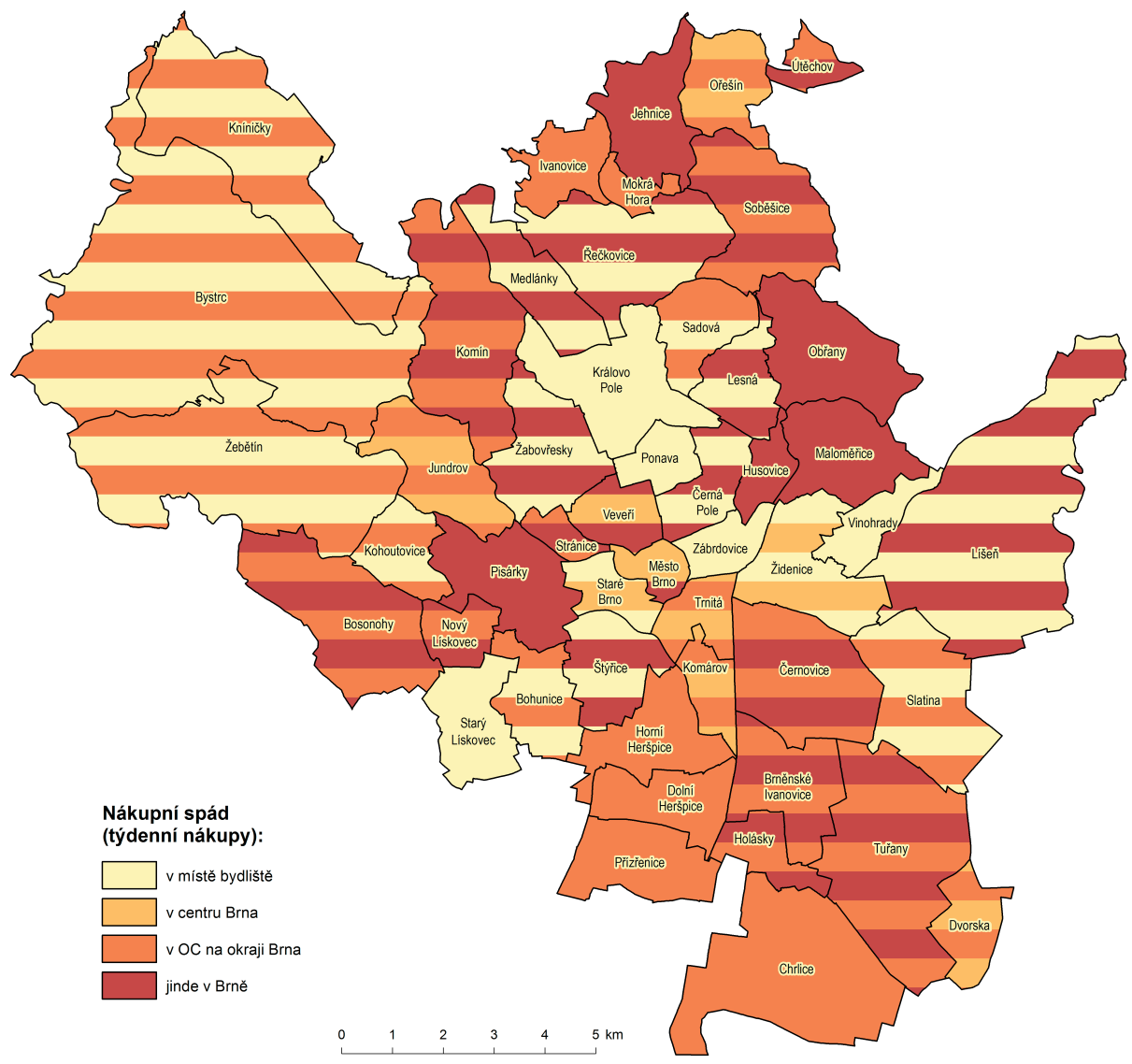

Zdroj: Šetření ve vnitřním Brně, podzim 2011 a jaro 2012.

Pro specializované či nepravidelné nákupy je podle očekávání preferováno centrum města (43\%) a nákupní centra na okraji (34 \%). Vzhledem k oblibě nákupních center v posledních letech a jejich vysoce pravděpodobné „schopnosti“ likvidovat některé malé obchody v centru města bychom u specializovaných nákupů přece jen předpokládali pořadí opačné. Mohl se zde také projevit vliv velmi oblíbeného nákupního centra Galerie Vaňkovka a obchodního domu Tesco (Tesco hypermarket), které, vzhledem k jejich poloze a dostupnosti, řadíme do středu města. 
Spádovost jednotlivých městských čtvrtí, resp. obyvatel v nich žijících k nákupním centrům a hypermarketům představuje obrázek 9.4. Obdobně jako na předchozích obrázcích (denní a týdenní nákupy) se jedná o nejčetněji zastoupený směr nákupů. Severní část města ovládají hypermarkety Globus a Nákupní centrum Královo Pole, jejichž sféry vlivu se do značné míry překrývají. Na jihu jsou dominantní nákupní centra Olympia a Avion Shopping Park, na západě získává stále silnější pozici nejmladší nákupní centrum Campus Square, na východě si drží pozice hypermarkety Interspar a Kaufland. $V$ hustě zalidněném centru města si zákazníky rozdělují nákupní centrum Vaňkovka a hypermarket Tesco (etážovou strukturou se jedná o typický obchodní dům), jejichž konkurenční boj

Obr. 9.4: Spádovost obyvatel městských čtvrtí k nákupním centrům a hypermarketům

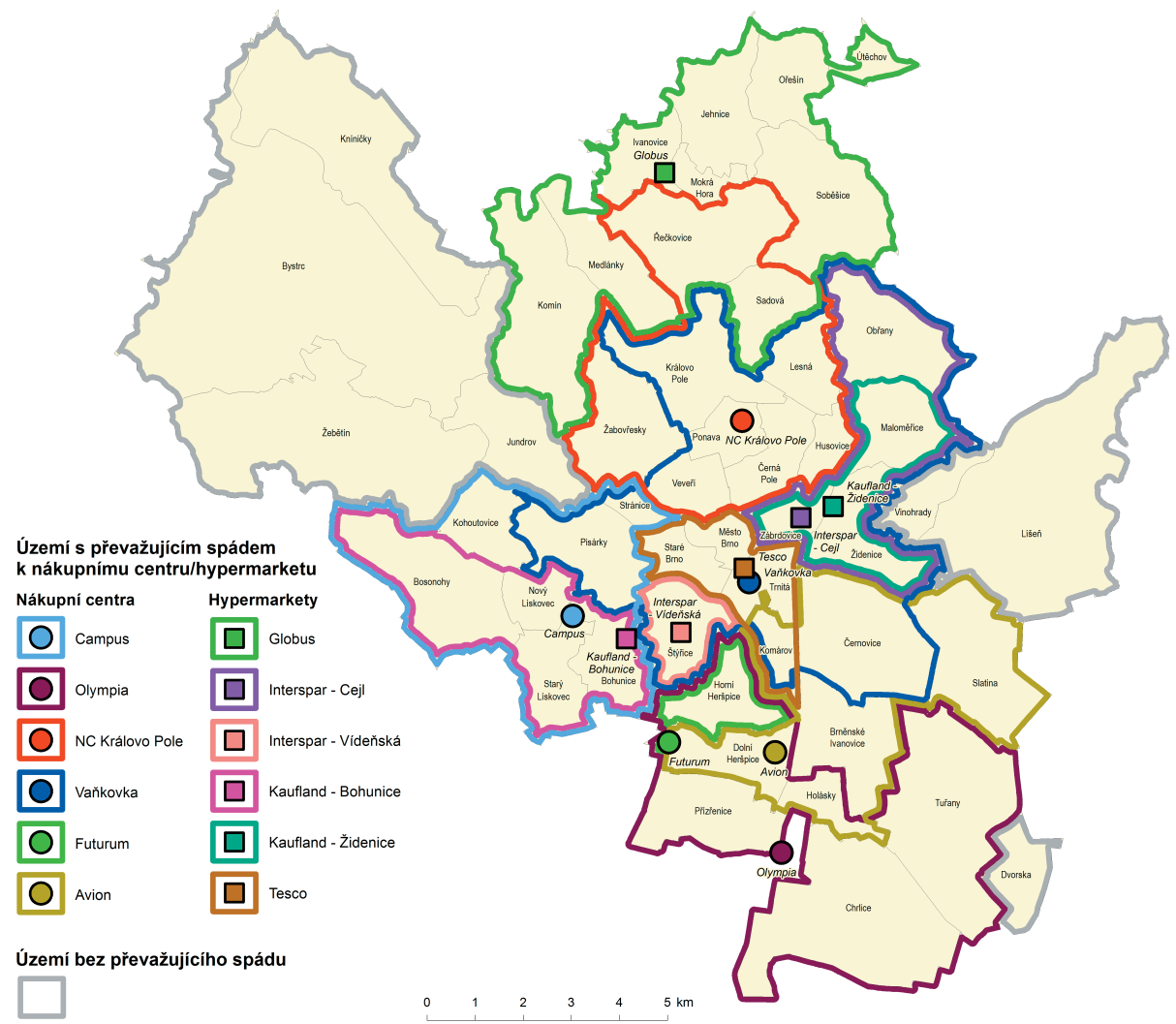

Zdroj: Šetření ve vnitřním Brně, podzim 2011 a jaro 2012. 
v nepotravinářském (specializovaném) zboží zejména u mladé a střední generace jednoznačně vyhrává prvně jmenovaný subjekt. Některé městské čtvrti na severozápadě, východě a jihovýchodě města jsou k nákupním centrům a hypermarketům spádově nevyhraněné, jejich obyvatelé rozdělují př́zeň rovnoměrně mezi více subjektů. Jedná se jak o velké sídlištní komplexy (Bystrc, Kohoutovice, Vinohrady, Líšeň, Slatina), tak o populačně malá předměstí s venkovskou zástavbou (Kníničky, Žebětín, Dvorska).

Tab. 9.2: Rozdíly v nákupním spádu obyvatel dle velikosti městské čtvrtě, věku, vzdělání a ekonomické aktivity

\begin{tabular}{|c|c|c|c|c|c|c|c|}
\hline \multirow[b]{3}{*}{ Faktory } & \multirow[b]{3}{*}{ Kategorie } & \multicolumn{6}{|c|}{ Závislé proměnné } \\
\hline & & \multicolumn{3}{|c|}{ denní nákupy (\%) } & \multicolumn{3}{|c|}{ víkendové nákupy (\%) } \\
\hline & & 올 & 疍 & 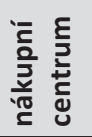 & 올 & 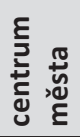 & 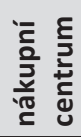 \\
\hline \multirow{4}{*}{$\begin{array}{l}\text { Populační } \\
\text { velikost } \\
\text { čtvrtě }\end{array}$} & do 5000 & $40 \%$ & $16 \%$ & $24 \%$ & $9 \%$ & $14 \%$ & $47 \%$ \\
\hline & $5000-9999$ & $65 \%$ & $20 \%$ & $7 \%$ & $36 \%$ & $16 \%$ & $25 \%$ \\
\hline & $10000-19900$ & $77 \%$ & $8 \%$ & $6 \%$ & $46 \%$ & $10 \%$ & $23 \%$ \\
\hline & 20000 a více & $85 \%$ & $4 \%$ & $1 \%$ & $49 \%$ & $11 \%$ & $13 \%$ \\
\hline \multirow{5}{*}{ Věk } & $15-19$ & $64 \%$ & $24 \%$ & $4 \%$ & $32 \%$ & $16 \%$ & $35 \%$ \\
\hline & $20-29$ & $66 \%$ & $12 \%$ & $10 \%$ & $35 \%$ & $16 \%$ & $28 \%$ \\
\hline & $30-49$ & $67 \%$ & $10 \%$ & $11 \%$ & $35 \%$ & $10 \%$ & $29 \%$ \\
\hline & $50-59$ & $68 \%$ & $11 \%$ & $11 \%$ & $36 \%$ & $15 \%$ & $25 \%$ \\
\hline & 60 a více & $77 \%$ & $6 \%$ & $6 \%$ & $43 \%$ & $11 \%$ & $16 \%$ \\
\hline \multirow{3}{*}{ Vzdělání } & $\begin{array}{l}\text { základní a střední } \\
\text { bez maturity }\end{array}$ & $72 \%$ & $10 \%$ & $8 \%$ & $44 \%$ & $12 \%$ & $19 \%$ \\
\hline & střední s maturitou & $67 \%$ & $12 \%$ & $10 \%$ & $33 \%$ & $12 \%$ & $27 \%$ \\
\hline & vysokoškolské & $67 \%$ & $10 \%$ & $12 \%$ & $32 \%$ & $12 \%$ & $32 \%$ \\
\hline \multirow{6}{*}{$\begin{array}{l}\text { Ekonomická } \\
\text { aktivita }\end{array}$} & pracující v Brně & $69 \%$ & $10 \%$ & $8 \%$ & $37 \%$ & $12 \%$ & $26 \%$ \\
\hline & pracující mimo Brno & $49 \%$ & $18 \%$ & $20 \%$ & $14 \%$ & $4 \%$ & $57 \%$ \\
\hline & studenti & $56 \%$ & $12 \%$ & $24 \%$ & $32 \%$ & $8 \%$ & $48 \%$ \\
\hline & nezaměstnaní & $62 \%$ & $29 \%$ & $0 \%$ & $24 \%$ & $33 \%$ & $33 \%$ \\
\hline & mateřská dovolená & $60 \%$ & $5 \%$ & $20 \%$ & $23 \%$ & $2 \%$ & $35 \%$ \\
\hline & starobní důchodci & $70 \%$ & $9 \%$ & $8 \%$ & $34 \%$ & $15 \%$ & $18 \%$ \\
\hline
\end{tabular}

Zdroj: Šetření ve vnitřním Brně, podzim 2011 a jaro 2012.

Pozn.: Kategorie s největši četností výskytu vážených proměnných jsou v tabulce znázorněny tučně. 
Kromě lokalizace městských čtvrtí v kontextu jejich prostorové vzdálenosti od nákupních center a hypermarketů ovlivňuje významně nákupní spád obyvatel, resp. lokální sílu nabídky a poptávky také faktor populační velikosti dané čtvrtě. Čím větší je velikost čtvrtě, tím vyšší je podíl osob nakupujících v místě bydliště. Platí to zejména pro denní nákupy, u víkendových a specializovaných nákupů je tato korelace slabší. Proto mají obyvatelé menších městských čtvrtí tendenci častěji nakupovat $v$ nákupních centrech a hypermarketech (podrobněji viz tabulka 9.2).

S přihlédnutím k sociodemografickým skupinám obyvatel výsledky šetření prokázaly, že podíl nakupujících v místě bydliště roste s věkem. Rozdíly mezi dalšími věkovými kategoriemi jsou zanedbatelné. Přestože senioři mají tendenci sledovat různé akce a slevy nabízené hypermarkety a nákupními centry na okraji Brna a ve svém volném čase (myšleno „kdykoliv“) za nimi jezdit levněji MHD, tento trend se $v$ preferenci jejich denních nákupů statisticky významně neprojevil. Senioři mají také nejnižší podíl mezi návštěvníky nákupních center, co se týče víkendových nákupů.

Mladí lidé do 20 let jsou nejčastěji zastoupeni mezi nakupujícími ve vnitřním městě v případě denních nákupů (také z důvodu lokalizace velkého počtu středních škol v blízkosti centra) a jsou také nejčastější věkovou kategorií návštěvníků nákupních center. Podíl nakupujících v nákupních centrech roste s dosaženým vzděláním. Míra četnosti nákupů v obchodních centrech také koreluje s ekonomickou úrovní domácnosti (výší měsíčního př́imu). Výsledky Ize interpretovat tak, že v obchodních centrech na okraji města nakupují častěji lidé s vyššími příjmy, které jsou většinou vázány na vyšší dosažené vzdělání. Dojižd'ka do zaměstnání je u těchto osob také častěji realizována automobilem, což jim zároveň umožňuje větší mobilitu při výběru místa obchodů.

Co se týče pracovní aktivity, pak mezi nakupujícími v místě bydliště převažují dle očekávání pracující v Brně a důchodci. Do centra města docházejí za nákupy nejčastěji nezaměstnaní, kteří svoji cestu spojují s dalšími pochůzkami, jež se neváží na pracovní aktivitu (služby, herny, restaurace apod.). Dále v centru města často nakupují také lidé dojíždějící za prací mimo Brno, přičemž se jedná zejména o ty, kteří využívají zastávky veřejné dopravy lokalizované v centru či jeho blízkosti (hlavní vlakové i autobusové nádraží).

Do nákupních center na okraji Brna jezdí především studenti, pracující na městské periferii či mimo město (denně dojíždějí autem) a matky na mateřské dovolené (také nejčastěji využívající auto). Nakupování mimo své bydliště, tedy v jiných čtvrtích Brna, je určeno spíše pro nepravidelné (víkendové) nákupy než pro nákupy denní potřeby. Nejčastěji jezdí mimo své bydliště matky na mateřské dovolené (40 \%) a senioři ( $35 \%$ ) - zde už se projevují jejich cesty za levnějšími nákupy, nikoliv ovšem do vzdálených nákupních center (viz výše), ale do bliže položených hyper- a supermarketů. 
Detailnější analýza výsledků šetření umožňuje zjistit oblibu maloobchodních jednotek u jednotlivých frekvenčních typů nákupů (podrobněji viz tabulka 9.3). Pro denní nákupy jsou preferovány zejména supermarkety, které mají své zastoupení ve většině městských částí (Albert v Brně 23 obchodů, Billa 10 obchodů, Brněnka - regionální řetězec 25 obchodů) a malé obchody s potravinami, príp. smíšeným zbožím. Svoji pozici si udržují také hypermarkety Kaufland (v Brně 3 obchody) a Tesco (v Brně 4 obchody).

U týdenních nákupů se neprojevila větší preference, za již zmiňované řetězce $v$ prípadě denních nákupư se zařadily hypermarket Globus (v Brně 1 obchod) a nákupní centrum Olympia. Specializovaným (nepravidelným) nákupům dominuje ve středu města lokalizovaná Galerie Vaňkovka, následují hypermarkety Tesco a centrum Olympia. $\mathrm{S}$ nevelkým odstupem jsou na čtvrtém místě malé specializované obchody $v$ centru města.

Tab. 9.3: Podíly jednotlivých maloobchodních jednotek na všech realizovaných nákupech

\begin{tabular}{|l|l|l|}
\hline Denní nákupy & $\begin{array}{l}\text { Týdenní (víkendové) } \\
\text { nákupy }\end{array}$ & $\begin{array}{l}\text { Specializované } \\
\text { (nepravidelné) nákupy }\end{array}$ \\
\hline Albert (Ahold) - supermarket & Tesco-hypermarket & Galerie Vaňkovka - nákupní \\
$26 \%$ & $15 \%$ & centrum \\
Malé obchody mimo větší & Albert (Ahold) - supermarket & $26 \%$ \\
řetězce & $14 \%$ & Tesco-hypermarket \\
$15 \%$ & Kaufland-hypermarket & $16 \%$ \\
Billa (Rewe)-supermarket & $14 \%$ & Olympia-nákupní centrum \\
$14 \%$ & Billa (Rewe)-supermarket & $15 \%$ \\
Brněnka-supermarket & $10 \%$ & Malé specializované obchody \\
(regionální řetězec) & Globus-hypermarket & v centru města \\
$7 \%$ & $6 \%$ & $14 \%$ \\
Kaufland-hypermarket & Olympia-nákupni centrum & Avion Shopping Park \\
$7 \%$ & $5 \%$ & - nákupní centrum \\
Tesco-hypermarket & & $6 \%$ \\
$6 \%$ & & \\
\hline
\end{tabular}

Zdroj: Šetření ve vnitřním Brně, podzim 2011 a jaro 2012.

Způsob dopravy za nákupy je primárně určován frekvenčním typem a směrem nákupu (viz také obrázek 9.5). Denní nákupy v blízkosti bydliště jsou uskutečňovány podle předpokladu především pěšky (60 \% odpovědí). K týdenním i specializovaným nákupům je již nejvíce využíváno auto (v obou prípadech 52 \%), což pramení z převážně periferní lokalizace a uzpůsobení nákupních center a hypermarketů pro dopravu automobily. Pokud se týdenní a zejména 
specializované nákupy uskutečňuji v centru města, je hojně využívána také MHD (22, resp. $41 \%)$.

Auto využívají $k$ nákupům o něco častěji muži než ženy, což platí poněkud překvapivě zejména u denních nákupů. Nejčastěji jezdí autem za nákupy střední generace (30-49 let), nejméně dle očekávání senioři nad 60 let. S rostoucím vzděláním roste také používání vozu k nákupům a klesá využití MHD a pěší chůze.

Obr. 9.5: Způsoby dopravy za nákupy v členění dle tří základních frekvenčních typů nákupů

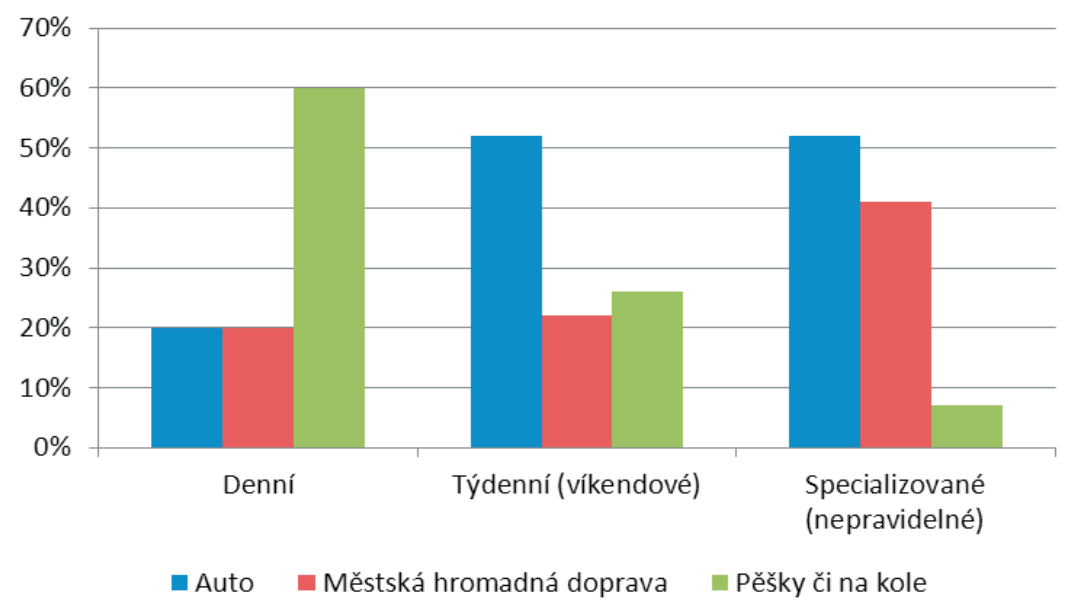

Zdroj: Šetření ve vnitřním Brně, podzim 2011 a jaro 2012.

Pokud se zaměŕíme pouze na základní potraviny, lze vyhodnotit i frekvenci nákupů. Denně (37 \% všech odpovědí) nakupují matky na mateřské dovolené a pracující z větších rodin. Jedná se většinou o nákupy v blízkosti bydliště. Dvakrát až třikrát týdně nakupují potraviny důchodci a nezaměstnaní, jedenkrát týdně či nižší frekvence je typická pro nejmladší věkovou kategorii 15-19 let (většinu nákupů zde zajištují rodiče). Co se týče pohlaví a vzdělání, nebyly mezi kategoriemi zjištěny významnější statistické rozdíly.

$\checkmark$ př́padě nákupů základních potravin jsou dle typů maloobchodních jednotek preferovány supermarkety (více než polovina odpovědí), což dokládá také tabulka 9.4. Na dalších místech jsou hypermarkety a menší prodejny se samoobsluhou. Z pohledu sociálních skupin byl potvrzen předpoklad, že v menších prodejnách a diskontech nakupují především starší věkové kategorie, v supermarketech a hypermarketech mladí lidé a střední generace. Nákupní centra se 
v tomto ohledu prakticky nijak speciálně neprofilují. Pohlaví a vzdělání nevykazuje významnější statistickou korelaci.

Z tabulky 9.4 je patrné, že právě v nákupních centrech se uskutečňuje více než polovina všech nákupů nepotravinářského sortimentu. S velkým odstupem následují hyper- a supermarkety a menší prodejny v centru města. Starší věkové skupiny (nad 50 let) opět preferují menší prodejny v okolí bydliště, příp. supermarkety, mladá a střední generace nakupuje nepotravinářské zboží zejména v nákupních centrech a hypermarketech. Např. v nákupních centrech nakupuje $70 \%$ respondentů ve věku do 20 let, ale jen 25 \% osob starších 60 let. Slabou korelaci vykazuje vzdělání - lidé s vyšším vzděláním podle očekávání nakupují častěji v nákupních centrech či v menších prodejnách v centru města a vyhýbají se supermarketům, kde nakupují nejvíce lidé se základním vzděláním.

Tab. 9.4: Preference typů maloobchodních jednotek u potravin a nepotravinářského zboží (podíly ze všech realizovaných nákupů)

\begin{tabular}{|l|l|}
\hline Potraviny & Nepotravinářské zboží \\
- typ maloobchodní jednotky & - typ maloobchodní jednotky \\
\hline supermarket & nákupní centrum \\
$54 \%$ & $54 \%$ \\
hypermarket & hypermarket \\
$20 \%$ & $15 \%$ \\
menši prodejna se samoobsluhou & supermarket \\
$12 \%$ & $13 \%$ \\
nákupní centrum & menši prodejna v centru města \\
$7 \%$ & $12 \%$ \\
prodejna s pultovým prodejem & menši prodejna v okolí bydliště \\
$4 \%$ & $5 \%$ \\
diskont & diskont \\
$3 \%$ & $1 \%$ \\
\hline
\end{tabular}

Zdroj: Šetření ve vnitřním Brně, podzim 2011 a jaro 2012.

Na otázku „Který typ prodejny ve městě nejvíce postrádáte?“ odpovědělo 77 \% respondentů, že žádný. Tato jednoduchá odpověd' pramení do značné míry z široké nabídky maloobchodních jednotek, jež je pro město velikosti Brna typická. Je to také odezva na současnou vrcholnou fázi transformace maloobchodní sítě, trvající v České republice již 20 let. Pokud se přece jen část respondentů $k$ této otázce konkrétně vyjádřila, tak se jednalo o mladé lidi do 20 let, jimž tradičně chybí více obchodů s textilem, a senioři, kteří postrádají obchody s domácími potřebami. Pohlaví a vzdělání nevykazuje statisticky významné rozdíly.

S předchozí otázkou souvisí také další dotaz, a to na změnu nákupního chování respondentů $v$ posledních zhruba pěti letech. To je doba, kterou jsou respondenti 
schopni si reálně připomenout a dát do souvislostí. Pro větší názornost uvádíme odpovědi v následující tabulce 9.5. Pro více než polovinu oslovených se v blízkosti obvyklých nákupních míst nic zásadního nezměnilo. Rozšíření nabídky prodejen a sortimentu v místě bydliště, resp. potřebu nakupovat mimo své bydliště v důsledku chybějící nabídky pocituje zhruba stejná část respondentů. Pouze $13 \%$ dotázaných preferuje nově otevřené velkoplošné prodejny, což je mimo jiné reakce na to, že hypermarkety a nákupní centra vznikaly v Brně nejvíce před zhruba 10-12 lety.

\section{Tab. 9.5: Změny v nákupním chování obyvatel}

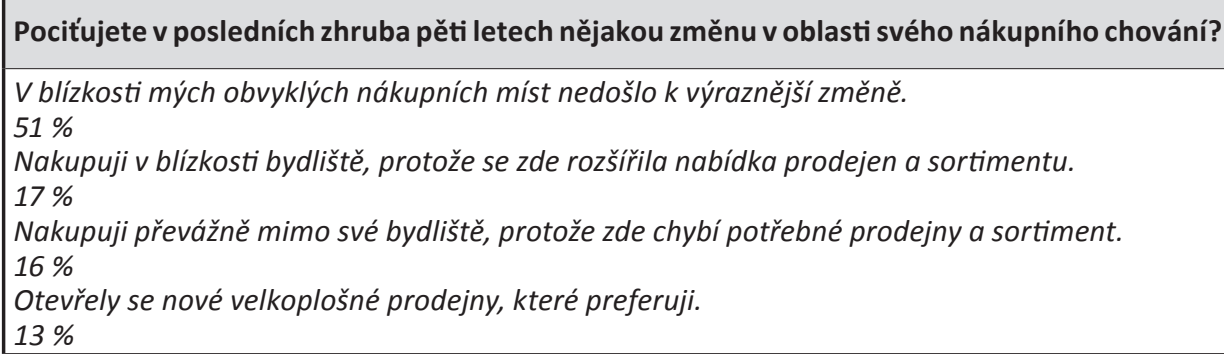

Zdroj: Šetrení ve vnitřním Brně, podzim 2011 a jaro 2012.

\subsection{Shrnutí}

Výzkum realizovaný ve vnitřních hranicích města Brna měl rozkrýt některé specifické oblasti nákupního spádu a nákupního chování obyvatel. Denní nákupy (většinou základní potraviny) jsou uskutečňovány především v místě bydliště (2/3 odpovědí) a blízkém okolí, přičemž preferovanou jednotkou jsou supermarkety a malé obchody, které nejsou součástí etablovaných maloobchodních řetězců. Role hypermarketů a nákupních center je zatím druhořadá, ale jak naznačují také některé práce založené na dojížd'ce za maloobchodem v urbánním prostředí (Marjanen, 1995; Szczyrba, 2002; Mitríková, 2008 a další), bude jejich role do budoucna narůstat.

Týdenní nákupy jsou logisticky daleko vyrovnanější, oproti předpokladům stanoveným v hypotéze převažuje stále místo bydliště a blízké okolí (37 \% odpovědí), následované nákupními centry na okraji Brna a jinými městskými čtvrtěmi mimo místo bydliště. $V$ řadě lokalit byly $v$ minulých letech uvedeny do provozu hypermarkety (ale i supermarkety) se širokou nabídkou sortimentu a s častými slevami, čehož obyvatelé bydlící v okolí využívají. Význam nákupních center na okraji města je však již velmi patrný (28 \%). 
Pro specializované či nepravidelné nákupy je preferováno centrum města (43 \% odpovědí) a nákupní centra na okraji (34 \%), přičemž jsme zde očekávali pořadí přece jen opačné. Sílící pozice nákupních center vůči menším specializovaným obchodům v centru pro nákupy obyvatel města i jeho zázemí je však zřejmá i z dalších výzkumů (Szczyrba, 2002; Lowe, 2005; Crosby, 2005; McEachern, Warnaby, 2006; Van Leeuwen, Rietveld, 2011; Kunc et al., 2012a, 2012b). Při preferenci centra města sehrála svou roli také lokalizace oblíbeného nákupního centra Galerie Vaňkovka a obchodního domu Tesco s hypermarketem. Galerii Vaňkovka, ležící v bezprostřední blízkosti historického jádra a hlavního vlakového i autobusového nádraží, je možné považovat za úspěšný př́iklad regenerace bownfieldu, jež je součástí revitalizace městského centra. (Podobným př́kladem je nákupní centrum Bull Ring $v$ anglickém Birminghamu). Pokud ovšem odhlédneme od frekvenčních typů nákupů, pak pro nákupy nepotravinářského zboží jsou již jednoznačně preferována nákupní centra ( 54 \% všech nákupů), u potravin s totožným podílem dominují supermarkety.

Statistická analýza výsledků šetření prokázala některé korelační vazby jednotlivých populačních skupin a místa realizace nákupů. Potvrdila se hypotéza, že podíl nakupujících v místě bydliště roste s věkem. Naopak se zcela nepotvrdilo, že mladí lidé jednoznačně preferují nákupní centra většinou lokalizovaná na periferii. Právě mladí lidé do 30 let mají největší zastoupení mezi nakupujícími $v$ centru města a až poté v nákupních centrech. Jedná se o určitou potřebu potvrzení sociálního statusu - být viděn ve značkových prodejnách a nákupních centrech, tedy být v "centru dění, což dokládají také studie Kunce et al. (2010), Jacksona et al. (2011) či Spilkové (2012b). Konkrétně v Brně opět sehrává svůj vliv lokalizace nákupního centra Vaňkovka navazujícího bezprostředně na historické jádro. Vzdělání nemá na nákupní spád výraznější vliv, pouze u nákupních center statisticky významněji roste podíl nakupujících s vyšším dosaženým vzděláním.

Z hlediska specifických populačních segmentů a jejich pracovních aktivit ve vazbě na místo nákupů se profilují senioři jako obyvatelé města preferující jak místo bydliště a okolí, tak jiné městské čtvrti v Brně. Mimo své bydliště dojíždějí důchodci zejména za akčními nabídkami a slevami potravin, drogistického zboží apod. nabízenými hypermarkety a supermarkety. $V$ centru města nakupují nejčastěji nezaměstnaní a lidé dojiždějící za prací mimo Brno, v nákupních centrech potom studenti, pracující na periferii či mimo Brno a matky na mateřské dovolené. Část pracujících využívá možností nakupovat v místě pracovního výkonu.

Většina dotázaných (60\%) realizuje své denní nákupy v docházkové vzdálenosti, u týdenních a specializovaných nákupů již dominuje cesta autem (podobně ve svých pracích také např. Brown, 1991; Marjanen, 1995; Findlay et al., 2001; Szczyrba, 2002; Mitríková, 2008; Wagner, Rudolph, 2010 a řada dalších). 
K návštěvám nákupních center na okraji města je ovšem hojně využívána také městská hromadná doprava, což platí především pro seniory, teenagery a částečně i matky na mateřské dovolené.

Poslední testovaná hypotéza neprokázala jednoznačnou odpověd' na zlepšení nabídky maloobchodních prodejen a rozšíření služeb v posledních letech ve většině městských čtvrtí Brna. Převažující neutrální odpověd' na setrvalý stav v místech obvyklých nákupů respondentů je reflexí současného stavu zakonzervovanosti spojeného s globální ekonomickou recesí. Výstavba nových maloobchodních konceptů se $v$ České republice zarazila k roku 2008 a lidé si zřejmě „zvykli“ na nový maloobchodní standard, který se již tak razantně nezvyšuje, ale pouze koriguje v kontextu vyplňování mezer na trhu, zvyšující se konkurence a rostoucí nabídky služeb (viz také Kunc et al., 2012b; Spilková, 2012a).

Centra českých měst, včetně Brna, jsou vystavena stále sílícímu procesu komercializace, jehož jedním z důsledků je vytlačování prodejen potravin z centra města (Sýkora, 2001; Ilnicki, 2001; Poole et al., 2002; Kunc et al., 2012b). Prodejní plocha potravinářských prodejen v centru města Brna (ovšem nejen zde, ale i v jiných městských čtvrtích) neustále klesá (Mulíček, Osman, 2009) a klesá i plocha nepotravinářských specializovaných prodejen. Těžiště nákupů potravin i nepotravinářského sortimentu se přesouvá do sídlištních zón a na městskou periferii, kde jsou lokalizovány supermarkety a hypermarkety, často jako součást nákupních center.

Na druhou stranu je třeba připomenout fakt, že v posledních letech vznikla $v$ centru Brna řada malých specializovaných obchodů např. s masnými a mléčnými výrobky či cukrovinkami, večerek, farmářských prodejen apod., které si své zákazníky našly. Je známo, že např. řetězec Tesco hodlá budovat sít menších obchodů s potravinami v centrech českých měst (koncept Tesco Expres). Do městských center se chystají pronikat velcí developeři s novými nákupními a administrativními objekty, konkurence bude ovšem veliká. Podobně jako v Brně se developeři výstavbě nákupních center v blízkosti historických jader rozhodně nevyhýbají. Stačí se podívat na naše velká města Prahu (např. plánované Copa centrum na Národní třídě, ale nebude to rozhodně jediný objekt tohoto typu) či Ostravu (Nová Karolina), dále blízkou Bratislavu (Aupark), Krakov (Galerie Krakowska) nebo anglický Birmingham (Bull Ring shopping centre) a mnoho dalších.

Jak se tedy bude v kontextu denního urbánního systému vyvíjet maloobchod ve městě velikosti Brna ve střední Evropě? Centrum města bude patrně nadále ztrácet pozici, co se týče týdenních a nepravidelných nákupů. Pro denní nákupy bude sloužit především rezidentům, kteří nemají potřebu cestovat jinam, což prokázal také náš výzkum. Také pracující v centru budou využívat možností nákupu v blízkosti pracoviště. Udrží se některé malé specializované prodejny, velké 
formáty zde budou spíše výjimkou, a pokud se zde některé prosadí, budou svádět ostrý konkurenční boj. Kolem spádově silných nákupních center se budou postupně vytvářet nová sekundární „centra“, která k sobě přitáhnou i rezidenční a administrativní funkci. Potvrzení těchto a dalších podobných předpokladů odhalí již blízká budoucnost. 


\section{Olomoucká aglomerace: spádovost za službami v denním urbánním systému Olomouce}

\subsection{Metodika výzkumu}

Primárním cílem této části monografie je identifikace vybraného okruhu prostorových interakcí v denním urbánním systému Olomouce, tj. v regionu, kde převládají pracovní dojížd'kové toky do města Olomouc. Konkrétně se jedná o interakce dojižd'ky za širším spektrem služeb nekomerčního (sociálního) i komerčního charakteru, a to ve dvou hierarchických úrovních - v rovině lokální a v rovině mikroregionální. U maloobchodu byla pro nejbližší obce v zázemí Olomouce provedena i analýza prostorové diferenciace spádovosti do tří velkých nákupních center. Na základě těchto dojížd'kových toků je možné zkonstruovat jednotlivé spádové regiony pro konkrétní okruhy služeb, resp. syntetické anebo komplexní obslužné regiony. $V$ komparaci s předchozími výzkumy jsme se pokusili i o zachycení základních vývojových trendů v obslužní infrastruktuře a změn v dojížd'ce za službami.

Prvním krokem při regionálně orientovaném výzkumu by mělo být vymezení zájmového území, což bude $v$ našem případě region denního urbánního systému Olomouce. Koncept denních urbánních systémů (DUS) poprvé použil americký geograf Berry (1973), na evropském kontinentu potom britský geograf Hall (např. 1974; Hall, Hay, 1980), přičemž se jedná o systémy, které vyplývají z denního cyklu života obyvatel regionu, jsou vnitřně koherentní a navenek (relativně) uzavřené vzhledem $k$ dennímu pohybu obyvatel. Tomuto konceptu se na území České republiky nejvíce přibližují regionalizace Sýkory a Mulička (2009), resp. Haláse et al. (2010). V obou prípadech jde o vymezení regionů podle denní dojižd'ky obyvatel do zaměstnání, přičemž na označení obce jako centra dojížd'ky jsou ve srovnání např. s Hamplem (2005) kladeny daleko nižší kriteria, což umožňuje blíže identifikovat i mikroregionální až lokální úroveň.

Základní princip obou zmíněných regionalizací je stejný (vymezování podle největšího dojižd'kového toku), liší se jen v detailech, tj. v zařazování obcí, které jsou na pomezí sfér vlivu dvou nebo více center. Region Olomouce má podle Sýkory a Mulíčka (2009) 67 obcí, podle Haláse et al. (2010) 65 obcí (v obou prípadech včetně Olomouce). Oba takto vymezené regiony se překrývají až v případě 63 obcí, což je region, který můžeme označit jako denní urbánní systém (anebo pracovní zázemí) Olomouce a bude to zároveň náš výzkumný region, se 
kterým zde budeme pracovat. Téměř totožné je i vymezení spádového zázemí Olomouce podle základní verze Reillyho modelu (Kladivo et al., 2010).

Zkoumané území spadá celé do Olomouckého kraje, většina obcí leží v okrese Olomouc, dvě obce v okrese Prostějov (Olšany u Prostějova a Slatinky) a jedna obec $v$ okrese Přerov (Brodek u Přerova). Základ zkoumaného území představuje správní obvod obce s rozšířenou působností (ORP) Olomouc (45 obcí), část zasahuje do území správního obvodu ORP Litovel (deset obcí), Šternberk (pět obcí), Prostějov (dvě obce) a Přerov (jedna obec).

Metodický postup vychází z prací Maryáše $(1983,1988,1992)$. Údaje o pohybu obyvatel za službami nebývají běžně statisticky zjištóované, proto je nutné informace o vybavenosti obcí doplnit dotazníkovým šetřením. Maryáš (1988) doporučuje jako nejvhodnější způsob tzv. šetření prostřednictvím lokálních lídrů, nejlépe starostů obcí. I když i tyto informace mohou mít jistou míru subjektivity, odrážejí realitu mnohem více než analýza dostupných statických charakteristik. Dotazování prostřednictvím lokálních lídrů jsme tedy využili i pro náš výzkum. Šetření proběhlo na podzim roku 2009 s pomocí vyškolených tazatelů - studentů Univerzity Palackého v Olomouci. Základem byl poštovní a e-mailový kontakt, chybějící obce byly navštíveny osobně. Každý dotazník byl opatřen razítkem obecního úradu.

Původní, tři desetiletí starý dotazník byl mírně modifikován a přizpůsoben současné realitě. Zjištóvána byla dojižd'ka za veřejnými službami (zdravotnictví, školství), maloobchodem a komerčními službami, resp. za volnočasovými aktivitami (kultura, sport). ${ }^{28}$ Starostové v dotazníku vyplňovali hlavní (převážný spád), vedlejší (částečný spád) i okrajové (výjimečný spád) obce vyjižd'ky za těmito aktivitami a infrastrukturou. $V$ návaznosti na Maryášovu metodiku byla převážnému spádu přidělena hodnota 10 bodů, částečnému spádu 5 bodů a výjimečnému spádu 1 bod. Pro jednotlivé obce byla následně každému cíli $i$, který byl obcí uveden $v$ daném obslužném procesu $j$, přiřazena hodnota $v_{i j}$. Tato hodnota představuje relativní význam cíle $i$ pro určitou obec $v$ určitém obslužném procesu:

$$
v_{i j}=\frac{T_{i j}}{P C_{i j} * P T_{j}} * 100,
$$

kde $T_{i j}$ je bodová hodnota typu spádu do cíle $i$ v obslužném procesu $j, P C_{i j}$ počet cílů v tomto typu a $P T_{j}$ součet bodových hodnot všech typů intenzity spádu uváděných obcí v obslužném procesu $j$. 
V každé obci byl součet hodnot $v_{i j}$ roven $100 \%$ pro každý obslužný proces $j$. Každému obslužnému procesu byl dále přiřazen koeficient $k_{j}$ podle významu, resp. frekvence využívání. Celkový relativní význam $c v_{i}$ cíle $i$ pro danou obec za všechny hodnocené obslužné procesy je potom roven:

$$
c v_{i}=\frac{\sum_{j} v_{i j} * k_{j}}{\sum_{i} \sum_{j} v_{i j} * k_{j}} * 100 .
$$

Opět platí, že v každé obci $\sum_{C v_{i}}=100 \%$.

Obce byly přiřazeny ke střediskům na základě převažujícího spádu v př́padě, kdy celkový relativní význam druhého nejsilnějšího střediska nedosahoval více než dvě třetiny hodnoty významu prvního. Obce nevykazující k žádnému středisku takto definovanou dostatečně dominantní spádovost byly považovány za oscilační.

Obec se jako středisko může uplatňovat na více hierarchických úrovních regionální působnosti. Jako základní obslužnou úroveň jsme definovali tzv. lokální úroveň, v rámci které jsou uzavřeny nejpodstatnější a nejvíce frekventované obslužné procesy. Obec byla považována za středisko lokálního významu v př́ipadě, že byla hlavním (převážným) cílem pro tři obce, přičemž byla zohledněna spádovost za službami i do obcí mimo vymezený region. Jako vyšší obslužnou úroveň jsme definovali tzv. mikroregionální úroveň, ve které jsou zahrnuty o něco méně frekventované obslužné procesy. Centrum takového mikroregionu obslouží v dané službě raádově větší počet obcí (zhruba 10-40 obcí), jejich minimální počet ale není možné přesně stanovit, protože se pohybujeme častokrát na pomezí sfér vlivu dvou a více obslužných mikroregionů. Konkrétní služba byla proto považována za generátor mikroregionální obslužní úrovně $v$ př́padě, že byla jako hlavní cíl v dané skupině služeb uvedena čtyři- a vícekrát méně ve srovnání s nejpočetněji uvedeným hlavním cílem.

Ve snaze zachytit specifický charakter spádovosti za různými typy služeb a zároveň zachovat komplexnost výzkumu budou samostatně vyčleněny parciální regiony zdravotnictví, školství, maloobchodu a služeb, resp. kultury a sportu. Následně se na jejich základě pokusíme o vymezení komplexních obslužných regionů. Za střediska komplexních obslužných regionů budeme považovat obce určené jako střediska ve třech ze čtyř parciálních regionů. Jednotlivým parciálním sférám budou přiřazeny koeficienty na základě jejich celkového regiotvorného významu. 
Vycházíme-li z úvahy, že region školství zahrnuje výlučně dojižd'ku žáků a studentů, a je tedy výrazně selektivní, bude přidělen střediskům školství koeficient 1. Střediskům zdravotnictví, resp. maloobchodu a služeb bude přidělen koeficient 2 , protože vyjadřují potenciální dojížd'ku všech obyvatel zkoumaného území. Střediska kultury a sportu byla sice rovněž vyčleněna na základě dojižd'ky všech obyvatel, i tak jim ale bude priřrazen nižší koeficient 1 . Důvodem je nejen jejich specifická povaha, ale hlavně inovativnost jejich zahrnutí do regionalizace na obslužném principu a snaha o zachování nejvyšší možné míry komparability s předešlými výzkumy, kde spádovost volnočasových aktivit nebyla zohledňovaná. Další postup již bude analogický jako při vymezování parciálních obslužných regionů.

\subsection{Regiony zdravotnictví}

Ve zkoumaném území byla pomocí dotazníků zjištována dojížd'ka za všeobecnými a dětskými lékaři, zubními lékaři, odbornými lékaři a dojížd'ka do nemocnic. Podle zvolené metodiky byla vybavenost ambulancí lékařem prvního kontaktu, tj. všeobecným lékařem, dětským lékařem a zubním lékařem základním identifikačním kritériem pro zdravotnická střediska (ve smyslu obcí) lokální úrovně. Jako střediska mikroregionální úrovně byly potom označeny obce disponující ordinací odborného lékaře. Dojižd'ka do nemocnic byla v dotaznících rovněž zjištovaná, v tomto prípadě se však jedná o proces charakteristický pro vyšší než základní mikroregionální úroveň spádovosti, bylo by možné ji spíše označit za proces mezoregionální. Ze závěrečného vyhodnocení byla proto spádovost do nemocnic vynechána. $V$ případě, že by byla vyhodnocována samostatně, celý výzkumný region by spádoval pod Fakultní nemocnici Olomouc (FNOL), jen některé obce na okraji by oscilovaly mezi Olomoucí a Šternberkem (sedm obcí), Olomoucí a Prostějovem (dvě obce) a Olomoucí a Přerovem (dvě obce). Ve Šternberku, Prostějově i Přerově se nacházejí nemocnice patřící pod zdravotnická zařízení skupiny AGEL, všechny středně náročné a náročné výkony zabezpečuje FNOL.

Na lokální úrovni je identifikovatelný silný vliv centrálního města Olomouc, přesto však bylo možné vyčlenit ve zkoumaném regionu tři vnitřní zdravotnické regiony (Lutín, Velká Bystřice, Tršice) v jeho nejbližším zázemí a několik spádových obcí na jeho okraji (viz obrázek 10.1). Současně se v okrajových obcích uplatňuje vliv větších měst mimo region, projevující se hlavně oscilací dojižd'ky. Vyšší spádovost obcí do Olomouce je možné pozorovat podél dopravních komunikací regionálního významu, dálniční tahy působí spíše negativně. Existuje předpoklad, že na lokální úrovni se dojižd'ky do menších zdravotnických středisek zúčastňuje převážně ekonomicky neaktivní obyvatelstvo. Jedním z následků pracovní migrace obyvatel je totiž i využívání městských zdravotnických zařízení mladou a střední generací pracující v Olomouci. 
Z pohledu zdravotnických služeb mikroregionální úrovně je dominance Olomouce daleko výraznější (viz obrázek 10.2). Přímo v regionu není žádné jiné středisko tohoto hierarchického významu, jen v jeho okrajových částech registrujeme některé obce spádující a hlavně oscilující mezi Olomoucí a středisky mimo region. Nejpatrnější je vliv Litovle v severozápadní části regionu, hlavně v obcích, které i administrativně patří pod ORP Litovel. Zároveň samozřejmě platí, že střediska vyšší obslužní úrovně jsou i středisky na nižších úrovních obsluhy.

Sít zdravotnických zařízení se ve zkoumaném regionu z pohledu časového vývoje př́liš neměnila. Došlo jen k adaptaci na nové (polo)tržní podmínky a ke změnám vlastnických vztahů. Spádovost za zdravotnickými zařízeními je stabilní. Podle práce Szczyrby et al. (2006) sice došlo ve správním obvodu ORP Olomouc k prudkému nárůstu počtu samostatných ordinací (ze 34 v roce 1989 na 61 v roce 2005), většina těchto ordinací však vznikla prímo ve městě Olomouc.

\section{Obr. 10.1: Regiony zdravotnictví lokální úrovně v DUS Olomouce}

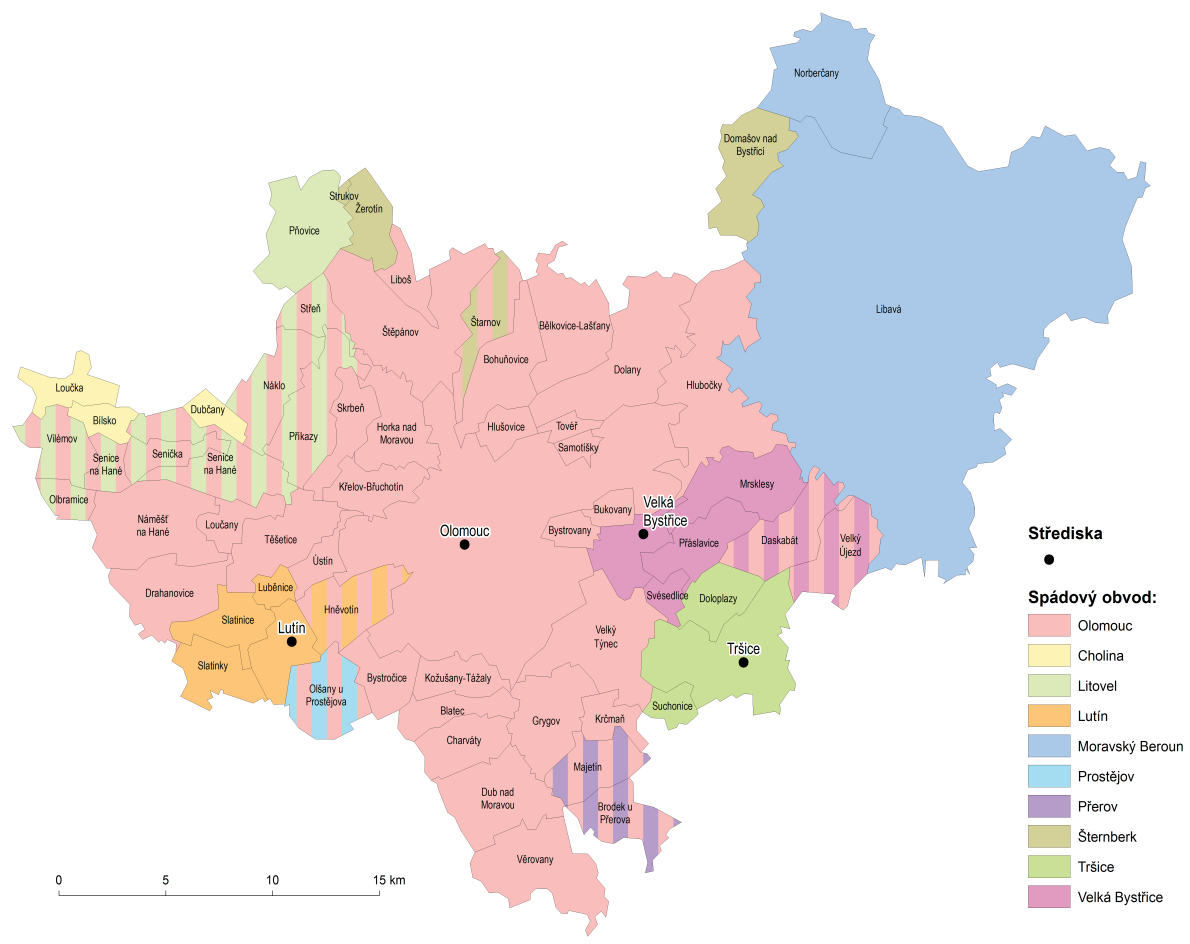

Zdroj: Šetřenív Olomouci a jeho zázemí, podzim 2009. 


\section{Obr. 10.2: Regiony zdravotnictví mikroregionální úrovně v DUS Olomouce}

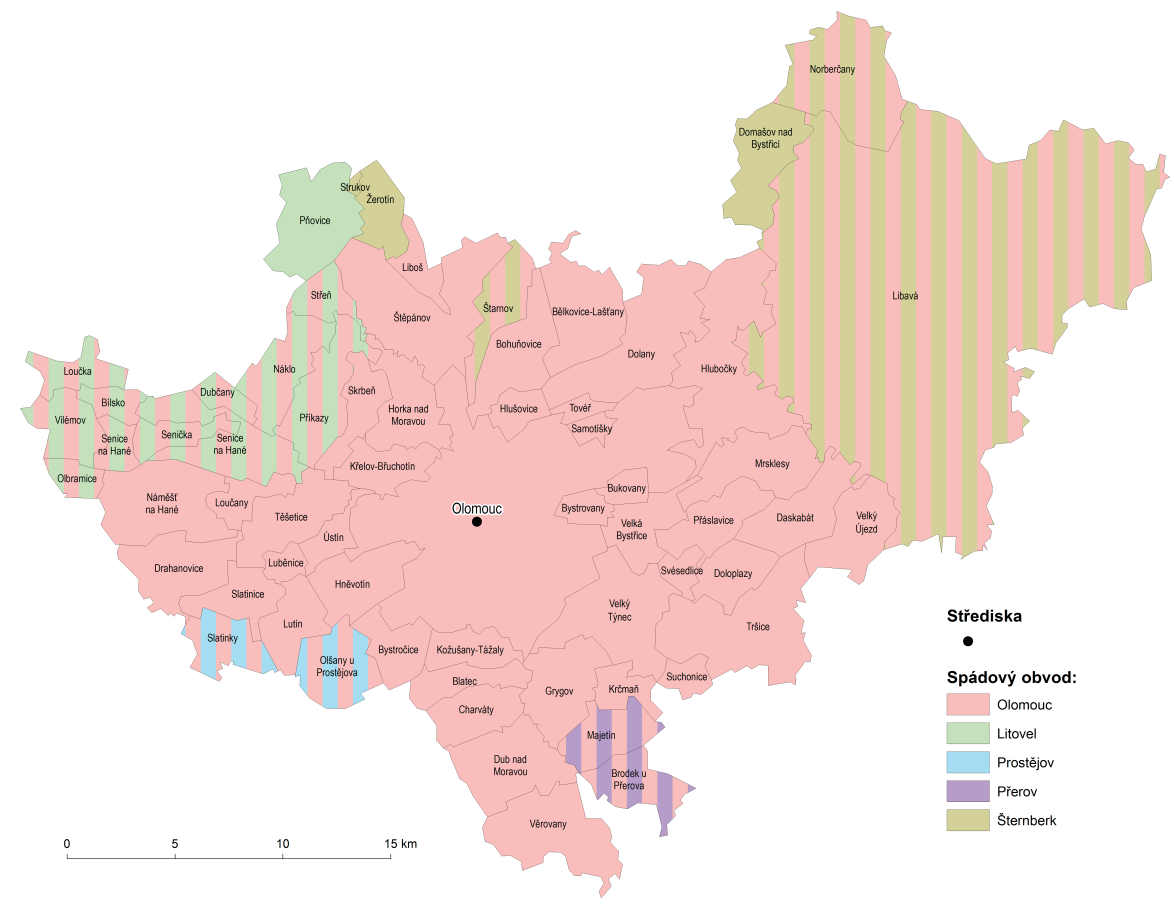

Zdroj: Šetrení v Olomouci a jeho zázemí, podzim 2009.

\subsection{Regiony školství}

Při hodnocení dojížd'ky do škol byla v zájmovém území zjištována a analyzována dojižd'ka do základních a středních škol. Ze základních škol byly brány v úvahu výlučně tzv. úplné základní školy, tj. školy s nižším i vyšším stupněm (1.-9. ročník). Vysoké školství a jeho spádovost je možné považovat za proces uzavřený na mezoregionální, příp. nižší makroregionální úrovni, tudiž nebyl do výzkumu vůbec zahrnut.

Jediným procesem hodnoceným v rámci školství na lokální úrovni byla dojižd'ka do úplných základních škol. Aktéři procesu dojížd'ky do ZŠ jsou děti, proto musí být její přepravní vzdálenost bez ohledu na hierarchii center minimalizována. $Z$ toho důvodu školské regiony lokální úrovně vykazují poměrně vysoký stupeň disperze. Ve sledovaném území se zformovalo až 11 lokálních regionů v okolí těchto sídel - Dub nad Moravou, Libavá, Lutín, Náměšt na Hané, Pňovice, Olomouc, Senice na Hané, Tršice, Velká Bystřice, Velký Týnec a Velký Újezd (viz 
obrázek 10.3). ${ }^{29}$ Úplné základní školy jsou i v jiných obcích, ale tyto školy již nemají spádový region minimálně dvou dalších obcí. V okrajových obcích území se znovu projevuje i vliv Šternberku, Litovle, Přerova a Prostějova, a to bud' jednoznačným spádem, anebo oscilací dojižd'ky.

Důležitým fenoménem, který může měnit lokální úroveň školství, je probíhající proces suburbanizace. Suburbanizační procesy způsobují celkovou změnu sociální struktury obyvatel obcí v zázemí Olomouce (více např. Biolek, Andráško, 2012), a tím i jejich požadavek na vyšší kvalitu služeb poskytovanou spíše městskými školami. Navíc venkovské školy v nejbližším zázemí Olomouce nemusí být schopny absorbovat zvyšující se počty dětí školního věku tam, kde je suburbanizační proces nejintenzivnější (Hlušovice, Samotišky, Tovéř a další). Zároveň se vlastnictví osobního vozidla stává standardem, což snižuje, resp. v některých lokalitách dokonce eliminuje vyžívaní hromadní dopravy.

Dalším problémem školství, tentokrát přímo ve městě Olomouc, je nedostatečná kapacita mateřských škol. $V$ devadesátých letech, kdy došlo k prudkému nárůstu individualismu a poklesu porodnosti, ubývaly ve velkém počty dětí předškolního věku. Proto bylo přistoupeno k rušení mateřských škol (hlavně firemních apod.), do kterých neměl kdo chodit. $V$ posledních letech, kdy dochází k některým odloženým porodům a zejména porodům žen silných populačních ročníků 1974-1980, již narůstajícímu počtu dětí současná kapacita mateřských škol nestačí. Podle údajů z olomouckého magistrátu není ve školkách umístněno více než $15 \%$ dětí předškolního věku.

Na mikroregionální úrovni byla zkoumána dojížd'ka do středních škol, což zahrnovalo široké spektrum středních odborných škol, učilišt' a gymnázií. Standardním postupem bylo $v$ rámci zkoumaného území identifikováno jediné středisko - Olomouc. Jeho spádová oblast ale byla ve srovnání se zdravotnictvím více zúžena vlivem působení okolních měst, konkrétně Šternberku, Litovle, Prostějova a Přerova (viz obrázek 10.4). Středoškolským zařízením sice disponují i některá menší sídla v blízkém zázemí Olomouce (Lutín, Velký Újezd), ta jsou však bud'to soukromá, nebo úzce specializovaná. Jejich využitelnost tedy není univerzální a na regionotvorné procesy mají minimální vliv. Právě profilace a kvalita výuky středních škol do značné míry souvisí s jejich návštěvností. Na rozdíl od lokální úrovně je tady možné pozorovat již nižší vázanost dojižd'ky na vzdálenost od místa bydliště. Celkově je ale možno konstatovat, že sít základních a středních škol se za posledních 20 let v regionu Olomouce př́liš neměnila.

29 Z důvodu přehlednosti byla v obrázku 10.3 použita jiná kartografická metoda než při ostatních grafických výstupech. 


\section{Obr. 10.3: Regiony školství lokální úrovně v DUS Olomouce}

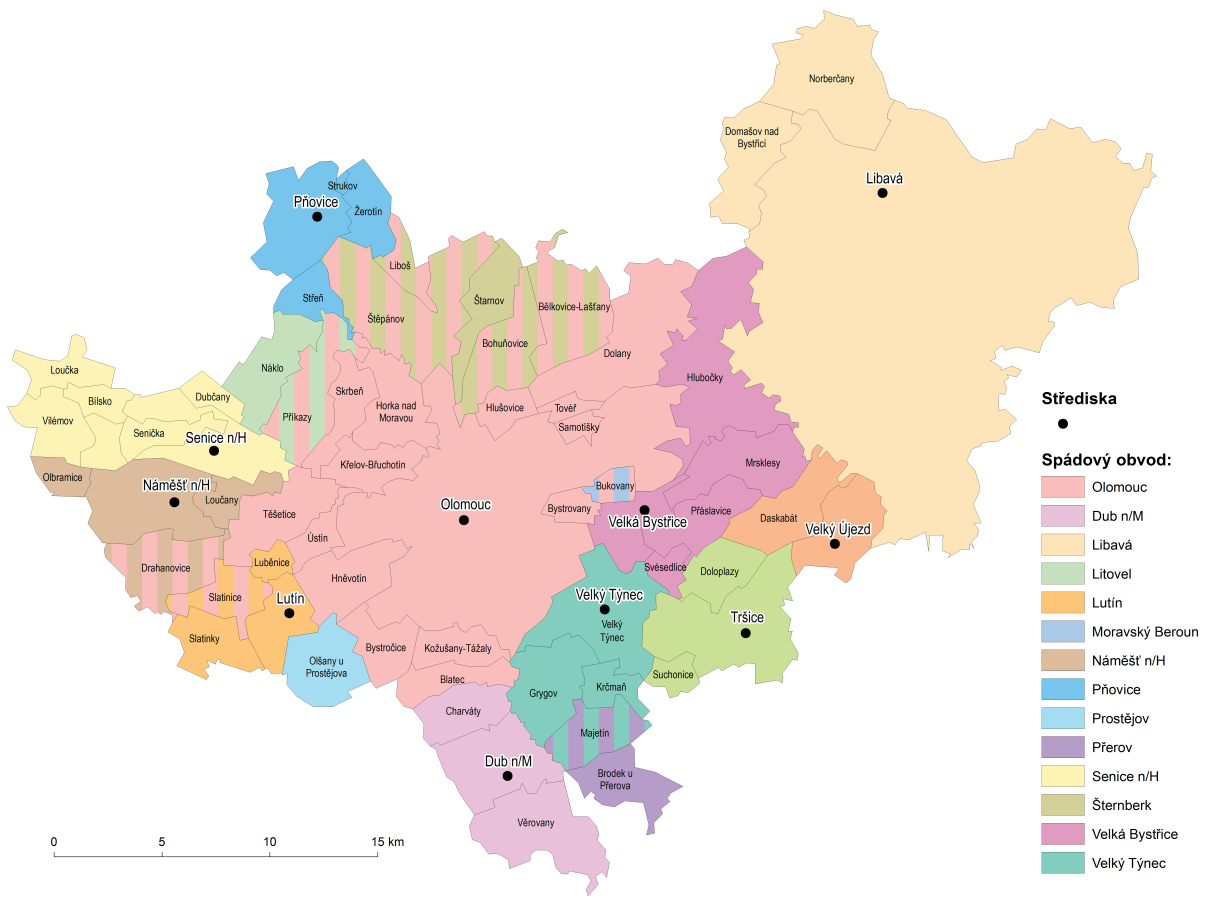

Zdroj: Šetření v Olomouci a jeho zázemí, podzim 2009.

\subsection{Regiony maloobchodu a služeb}

Za procesy nejvíce vystihující aktuální organizaci území podle obslužného principu jsme v našem výzkumu stanovili dojížd'ku za denními nákupy (potraviny a základní drogerie), nákupy běžného textilu a obuvi, nákupy průmyslového zboží (elektro, kola, sportovní potřeby apod.), nákupy nábytku a bytových doplňků, dojižd'ku za běžnými službami (kadeřník, čistírna, oprava obuvi, fotograf atd.), návštěvu banky a pojištovny (příp. její pobočky) a návštěvu lékárny. Nákupy zboží denní potřeby jsou sice u nadpoloviční většiny obcí uzavřené na úrovni samotné obce, záměrem ale bylo zjistit případné odchylky v povaze dojížd'ky obyvatel v zázemí města krajské úrovně, zejména vlivy koncentrace obchodu. I u ostatních procesů je možné předpokládat jistou změnu relativní uzavřenosti, resp. vzdálenosti, na kterou se uskutečňují cesty do cílových obcí ve srovnání s hodnotami z 80. let minulého století.

Komparací s Maryášovými závěry $(1988,1992)$ je možné konstatovat všeobecné zkrácení dojižd'kové vzdálenosti za maloobchodem u všech procesů. Jediný 


\section{Obr. 10.4: Regiony školství mikroregionální úrovně v DUS Olomouce}

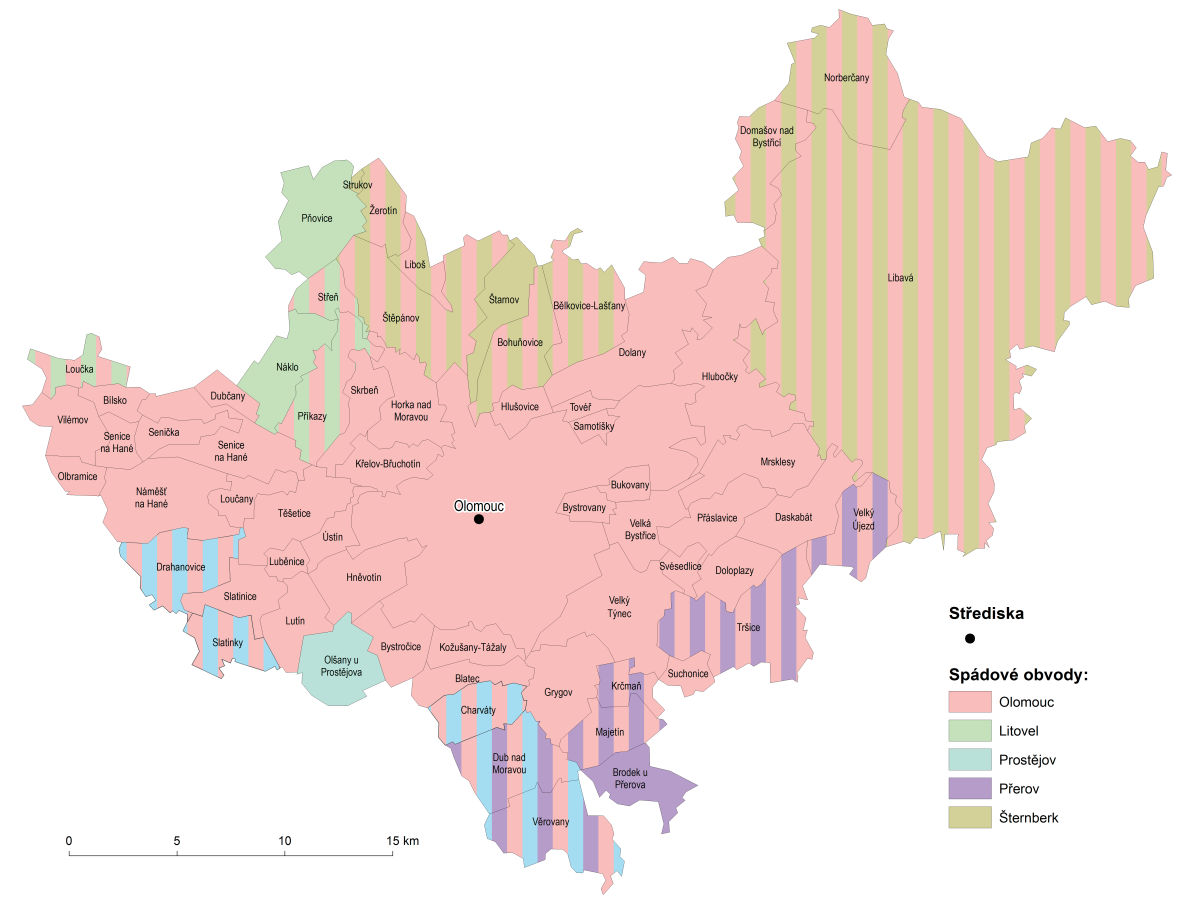

Zdroj: Šetření v Olomouci a jeho zázemí, podzim 2009.

nárůst vzdálenosti je u cílů denních nákupů, a to hlavně zásluhou trendu nakupování ve velkých nákupních centrech a posunu denní periodicity na periodicitu s nižší frekvencí. Jako lokální procesy vystupují podle zvolené metodiky návštěva lékárny, běžné služby, resp. návštěva banky a pojištóvny. Ve srovnání s minulostí se zkrátily především vzdálenosti dojížd'ky do lékáren. Vybavenost lékárnami se podstatně zlepšila, ve srovnání s rokem 1989 se zvýšil počet lékáren ve správním obvodu ORP Olomouc téměř trojnásobně (Szczyrba et al., 2006). Tento fakt nepřímo potvrzuje zlepšení zdravotní péče a vyšší vybavenost obcí základními zdravotnickými potřebami. Ostatní dojížd'kové procesy (textil a obuv, průmyslové zboží, nábytek a bytové doplňky) byly přirazeny k mikroregionální spádovosti. Opačný charakter posunu (zvětšování vzdálenosti) vykazuje dojižd'ka za nákupy textilu a obuvi. Před blízkostí nákupního zařízení je v současnosti upřednostňovaná kvalita (př́p. poměr kvalita/cena), rozsah sortimentu anebo jeho př́slušnost k určité značce. Nový prvek představuje dojižd'ka do finančních institucí, jejichž 
význam v poslední době narůstal. Tyto instituce ale začínají preferovat elektronický kontakt, takže Ize v této sféře očekávat další dynamický vývoj.

$\checkmark$ rámci zkoumané oblasti byla identifikována pouze dvě lokální střediska maloobchodu a služeb, schopná vytvořit si dostatečně velké spádové zázemí Olomouc a Náměšt na Hané. Mimo hranic oblasti se znovu profilují jako střediska Litovel, Šternberk, Prostějov a Moravský Beroun, Přerov má jen oscilační vliv (obrázek 10.5). Ve srovnání se zdravotnickou a školní péčí je možné pozorovat podstatné zvětšení spádové oblasti Olomouce, odpovídající v předešlých parciálních regionech téměř mikroregionální úrovni. Příčina je ve výrazně lepší obslužné vybavenosti města Olomouc a skutečnosti, že lokalizace komerčních služeb se daleko více přizpůsobuje největšímu objemu poptávky a nerespektuje menšinové (např. méně mobilní) skupiny obyvatelstva.

\section{Obr. 10.5: Regiony maloobchodu a služeb lokální úrovně v DUS Olomouce}

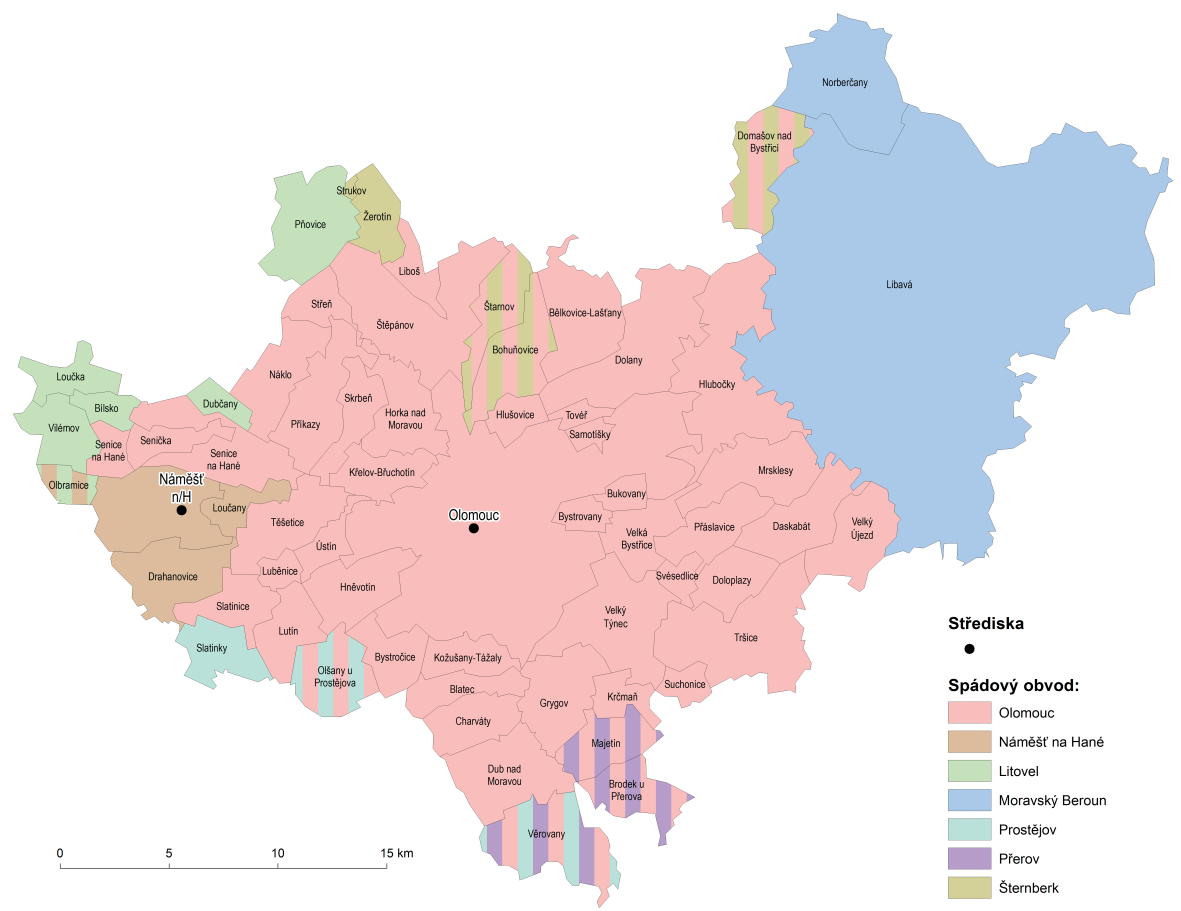

Zdroj: Šetření v Olomouci a jeho zázemí, podzim 2009. 
Zatímco urbánní sít maloobchodu a služeb funguje v podmínkách vysoko koncentrované poptávky a poskytuje širokosortimentní nabídku, rurální maloobchodní sít se uspokojuje s málo koncentrovanou poptávkou a je spojena s vyššími náklady oběhu zboží ve srovnání s městskou sítí. Výjimku tvoří velkoplošné maloobchodní jednotky lokalizované v důsledku suburbanizačních procesů často na okraji sídelních útvarů. Podobná nákupní střediska jsou v katastrech sídel Velký Týnec (Olympia) a Velká Bystřice (Makro). V obou případech je to velmi blízko Olomouce, proto byl jejich význam $v$ odpovědích značně podhodnocen (často jsou brána jako součást města Olomouc).

Na mikroregionální úrovni byla střediskovost ve zkoumaném území přisouzena pouze městu Olomouc, okrajově se projevil vliv Šternberku, Litovle, Přerova a Prostějova (viz obrázek 10.6). Spádová oblast Olomouce pokrývá prakticky celý region, pouze některé hraniční obce se přimykají k jiným městům nebo oscilují. Prostorový obraz dojižd'ky je podobný lokální úrovni, pouze mizí vliv Náměště na Hané a Moravského Berouna.

\section{Obr. 10.6: Regiony maloobchodu a služeb mikroregionální úrovně v DUS Olomouce}

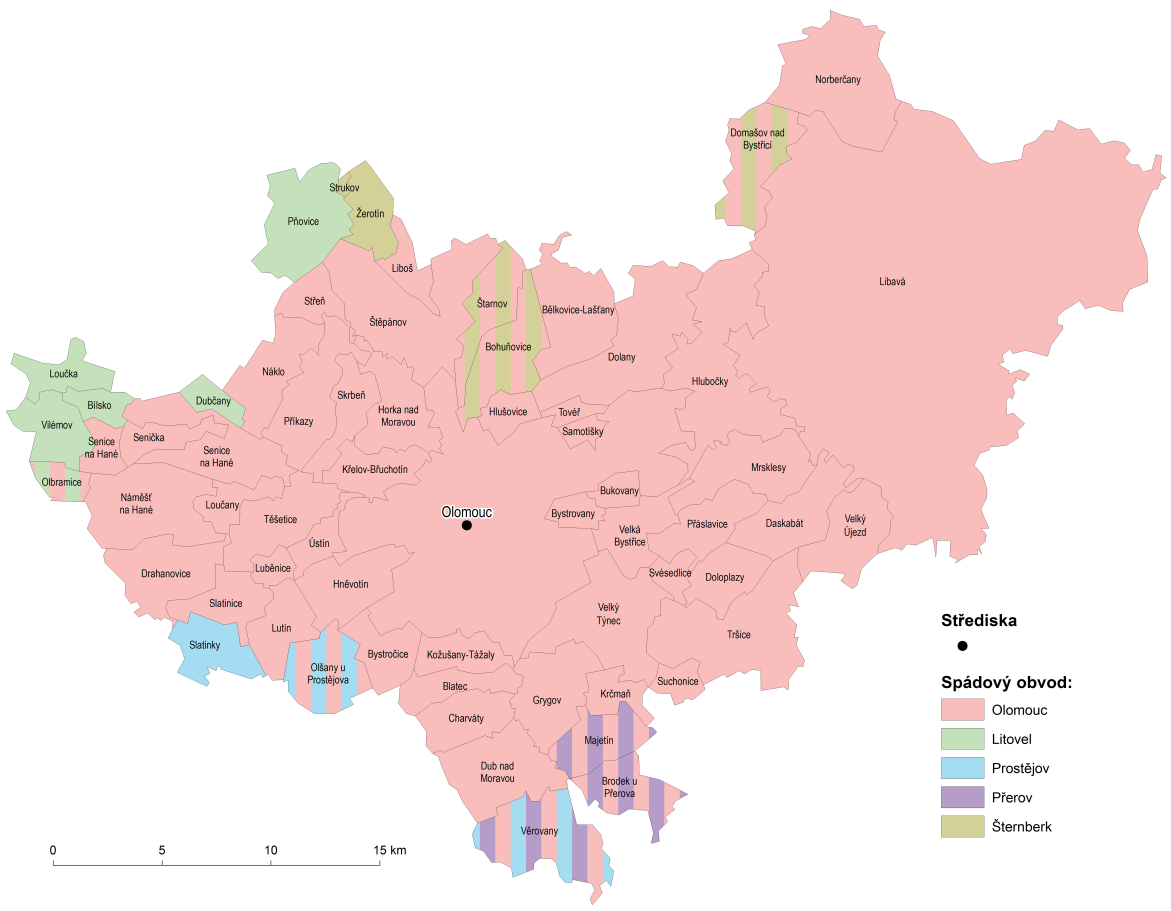

Zdroj: Šetření v Olomouci a jeho zázemí, podzim 2009. 
Kromě již zmiňované Olympie, lokalizované na hranici Velkého Týnce a Olomouce $v$ kontaktu S R 35 a plánovanou $R 55$, se v okrajových částech města Olomouc nacházejí další dvě velká nákupní centra. Obchodní centrum Haná je lokalizováno v blízkosti rychlostní silnice $\mathrm{R} 46$ Olomouc-Vyškov s pokračováním na dálnici $D 1$ směrem na Brno, Globus leží v blízkosti rychlostní silnice R 35 Olomouc-Mohelnice, která by po dostavbě měla pokračovat na Hradec Králové. Na základě dotazníkového výzkumu provedeného v obcích s časovou dostupností Olomouce do 20 minut (podle plánovače cest www.skoda-auto.cz) jsme provedli vymezení spádového zázemí do tří uvedených nákupních center. Výzkumu se v každé obci zúčastnil reprezentativní vzorek minimálně $10 \%$ obyvatel. Jednoznačná spádovost byla označena $v$ př́padě shody alespoň poloviny dotazovaných. Při menší jednoznačnosti odpovědí byla spádovost rozdělena mezi dvě obchodní centra, ke kterým se přiklonila více než třetina respondentů.

\section{Obr. 10.7: Spádovost k nákupním centrům z obcí v zázemí Olomouce}

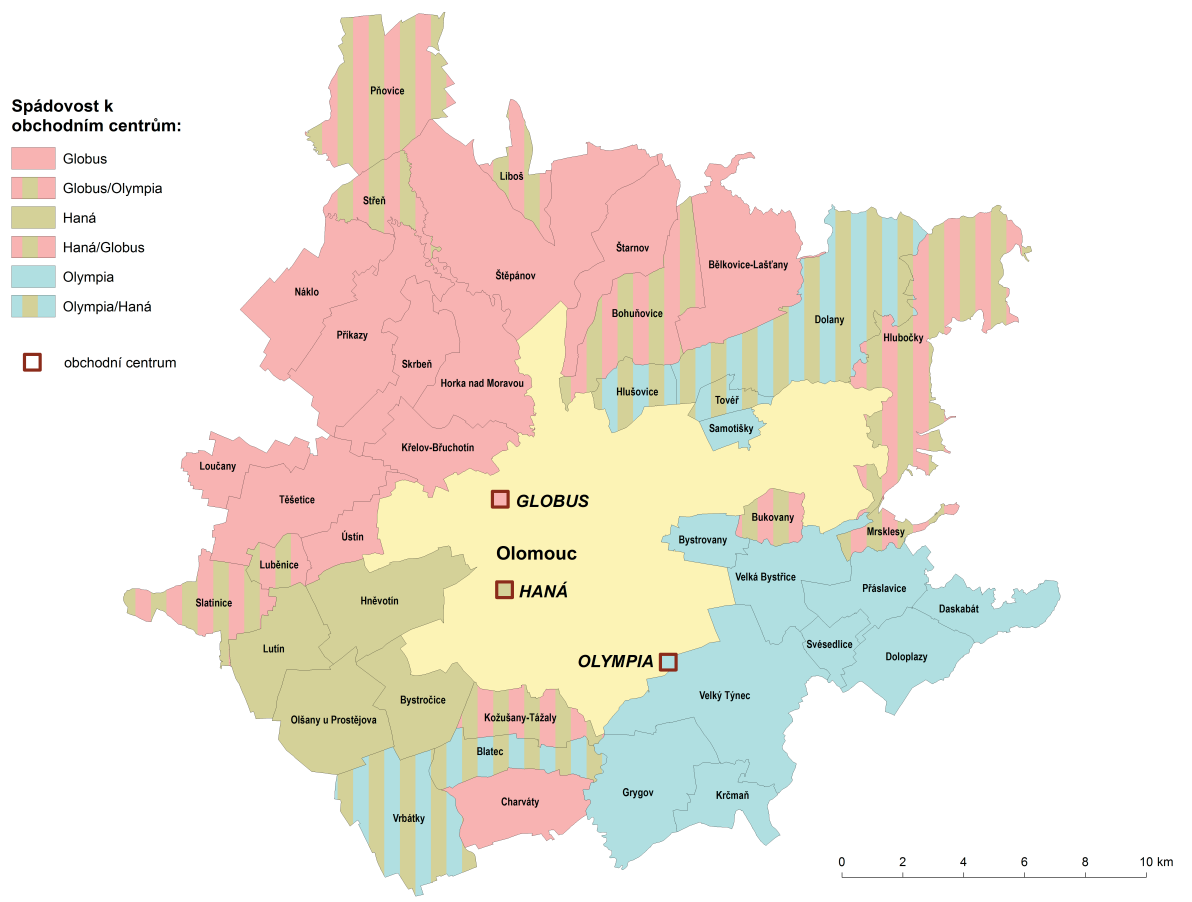

Zdroj: Šetření v Olomouci a jeho zázemí, podzim 2009. 
Plošně i populačně největší zázemí v obcích mimo Olomouc má Globus, nejmenší naopak OC Haná, kterému navíc směrem na jihozápad konkurují i blízké prostějovské hypermarkety a centra. Ukázala se i viditelná závislost preference obchodního centra na vzdálenosti, ale to pouze v nižších vzdálenostních relacích. Pokud se nákupní centrum nachází do vzdálenosti $8 \mathrm{~km}$ od obce, obyvatelé vždy preferují toto centrum. U obcí, které mají větší vzdálenost od nejbližšího obchodního centra (více než 8-10 km), již role vzdálenosti není důležitá. Obyvatelé se v těchto prípadech rozhodují podle jiných kritérií. Největší diverzifikace preferencí je v obcích na severovýchod od Olomouce, kde není lokalizováno žádné velké nákupní centrum. Je to prostor bez vysokokapacitních silničních komunikací v př́ijemném prostředí podhůří Nízkého Jeseníku a Oderských vrchů, kde i z těchto důvodů probíhají po roce 2000 intenzivní suburbanizační procesy. Podrobně znázorňuje prostorovou diferenciaci preferencí nákupních center obrázek 10.7.

\subsection{Regiony kultury a sportu}

Regiony dojížd'ky za kulturou a sportem nebyly doposud na území České republiky vymezeny. Do dotazníkového šetření byly zařazeny otázky zjištúující dojižd'ku za kulturními a sportovními akcemi, diskotékami a kinem. Ve všech př́padech byly dle zvolené metodiky (s výjimkou dojižd'ky do kin) přiřazeny lokální úrovni. Dojížd'ka do kin jako jediná patří pod mikroregionální úroveň a v tomto příspěvku nebude její spádovost graficky prezentována. Téměř celé zkoumané území v jejím případě spáduje pod Olomouc, s výjimkou pěti obcí spádujících $\mathrm{k}$ Litovli a po jedné obci k Šternberku a Prostějovu. Právě kina jsou těmi kulturními zařízeními, kterých prostorově nejvíce ubývalo, ve správním obvodu ORP Olomouc klesl jejich počet oproti roku 1989 na třetinu (Szczyrba et al., 2006). Snížila se i jejich diverzita v prostoru, většina se přesunula do velkých nákupních center. Dokonce i v samotné stotisícové Olomouci zůstalo mimo multiplexu funkční pouze jediné kino.

$\checkmark$ rámci lokální úrovně byla zvoleným metodickým postupem vymezena dvě střediska kultury a sportu, a to Olomouc a Přáslavice. Podobně jako v předešlých parciálních regionech i tu se $v$ hraničních obcích projevil vliv okolních měst, konkrétně Litovle, Šternberku, Moravského Berouna, Přerova a Prostějova (viz obrázek 10.8). Vznik spádového regionu Přáslavic poukazuje na odlišný charakter obslužných procesů volnočasových aktivit. K Přáslavicím deklarovala spádovost populačně několikanásobně větší obec Hlubočky a obec Mrsklesy. Není tady však pouze jediná dominantní aktivita, v roce 2009 se v Přáslavicích vybudovalo víceúčelové centrum, místní jsou aktivní např. také ve florbalu nebo fitness. Ostatní vymezené regiony víceméně kopírují spádovost na základě dojížd'ky za maloobchodem a službami. 


\section{Obr. 10.8: Regiony kultury a sportu lokální úrovně v DUS Olomouce}

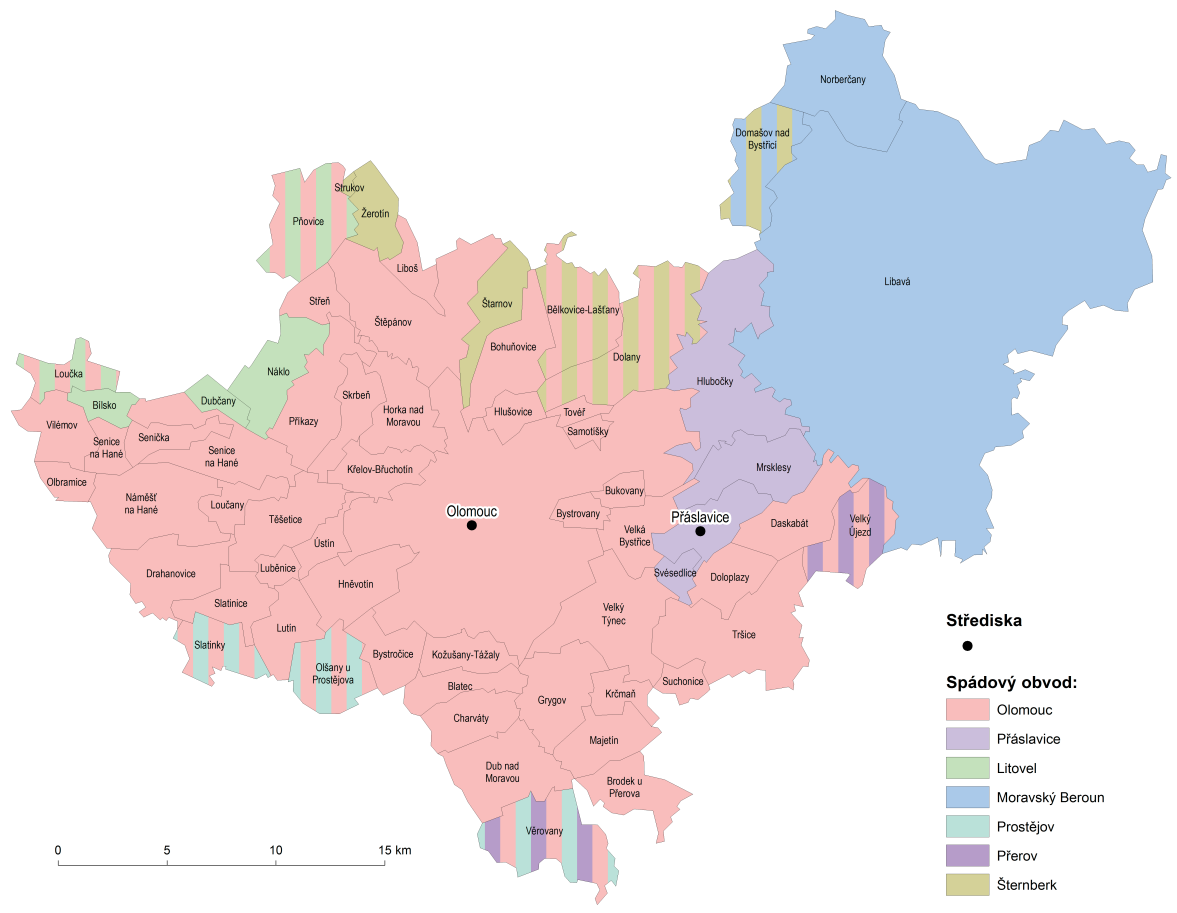

Zdroj: Šetření v Olomouci a jeho zázemí, podzim 2009.

\subsection{Komplexní obslužné regiony}

I když např. Hampl (2005) deklaruje svoji regionalizaci území České republiky jako komplexní sociogeografickou regionalizaci a vymezené regiony za komplexní mikroregiony, mezoregiony a makroregiony, pracoval při vymezování pouze s daty o dojižd'ce do zaměstnání a obslužnou spádovost nahradil dojížd'kou do škol, která se týká jen relativně úzce věkově ohraničené skupiny obyvatelstva a často má jiný směr než celková obslužná spádovost. Obslužná spádovost, či už reálná nebo modelovaná, je zohledňována v dřivějších pracích Hamplova kolektivu, přesto je však možné za nejkomplexnější regionalizační dílo považovat mapový výstup Maryáše a Řeháka (1987) z Atlasu obyvatelstva ČSSR z roku 1987.

$\checkmark$ denním urbánním systému Olomouce se jednoznačně potvrzuje dominantní poloha centrálního města Olomouc a jeho pravidelné koexistence s okolními centry jako Přerov, Prostějov, Litovel, Šternberk či Moravský Beroun. Registrujeme také poměrně vysoký stupeň shody se samotným vymezením denního urbánního 
systému, který byl vymezen na základě nejfrekventovanějšího a nejpočetnějšího pohybu - podle dojižd'ky do zaměstnání. Syntéza poznatků zároveň potvrzuje, že v zázemí tak velkého města, jako je Olomouc, není př́liš velký rozdíl při vymezení obslužných regionů na lokální a mikroregionální úrovni. Vymezené regiony se liší pouze v jedné části (obrázky 10.9 a 10.10) - při lokální úrovni spádují Libavá3 ${ }^{30}$ a Norberčany pod Moravský Beroun, při mikroregionální úrovni si Moravský Beroun již nevytváŕí samostatný region, Libavá a Norberčany proto oscilují mezi Olomoucí a Šternberkem. Na lokální úrovni sice vystupují některá menší centra, ale pouze při parciálních procesech. Co se týče nabídky služeb, nebyla již jejich větší komplexnost potvrzena.

Obr. 10.9: Komplexní obslužné regiony lokální úrovně v DUS Olomouce

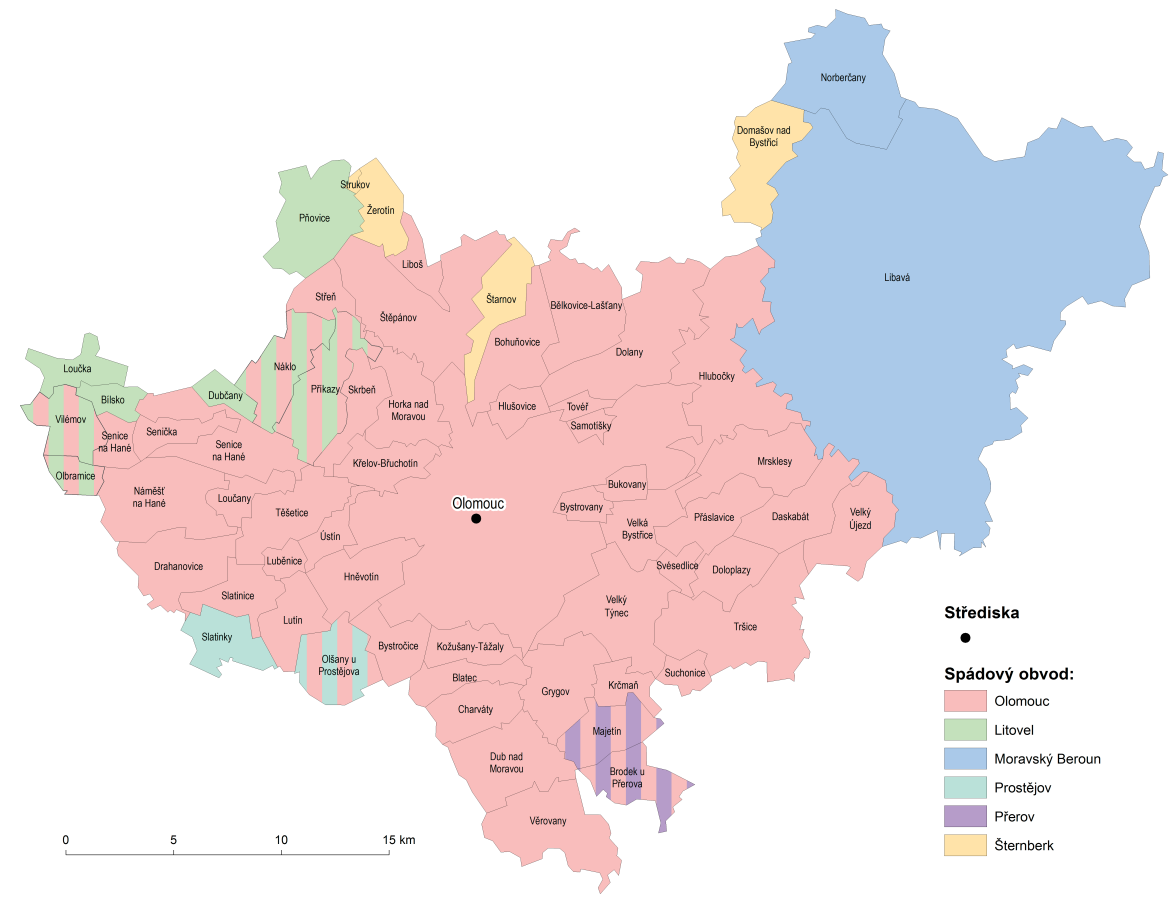

Zdroj: Šetření v Olomouci a jeho zázemí, podzim 2009. 
Z celkového počtu 63 obcí regionu spáduje na mikroregionální úrovni za službami mimo Olomouc pouze devět obcí, z toho čtyři k Litovli (Bílsko, Dubčany, Loučka a Pňovice), čtyři ke Šternberku (Domašov nad Bystřicí, Strukov, Štarnov a Žerotín) a jedna k Prostějovu (Slatinky). Mezi vlivem Olomouce a Litovle oscilují čtyři obce (Náklo, Olbramice, Př́íkazy a Vilémov), mezi Olomoucí a Šternberkem dvě obce (Libavá a Norberčany), mezi Olomoucí a Prostějovem jedna obec (Olšany u Prostějova) a mezi Olomoucí a Přerovem dvě obce (Majetín a Věrovany).

\section{Obr. 10.10: Komplexní obslužné regiony mikroregionální úrovně v DUS Olomouce}

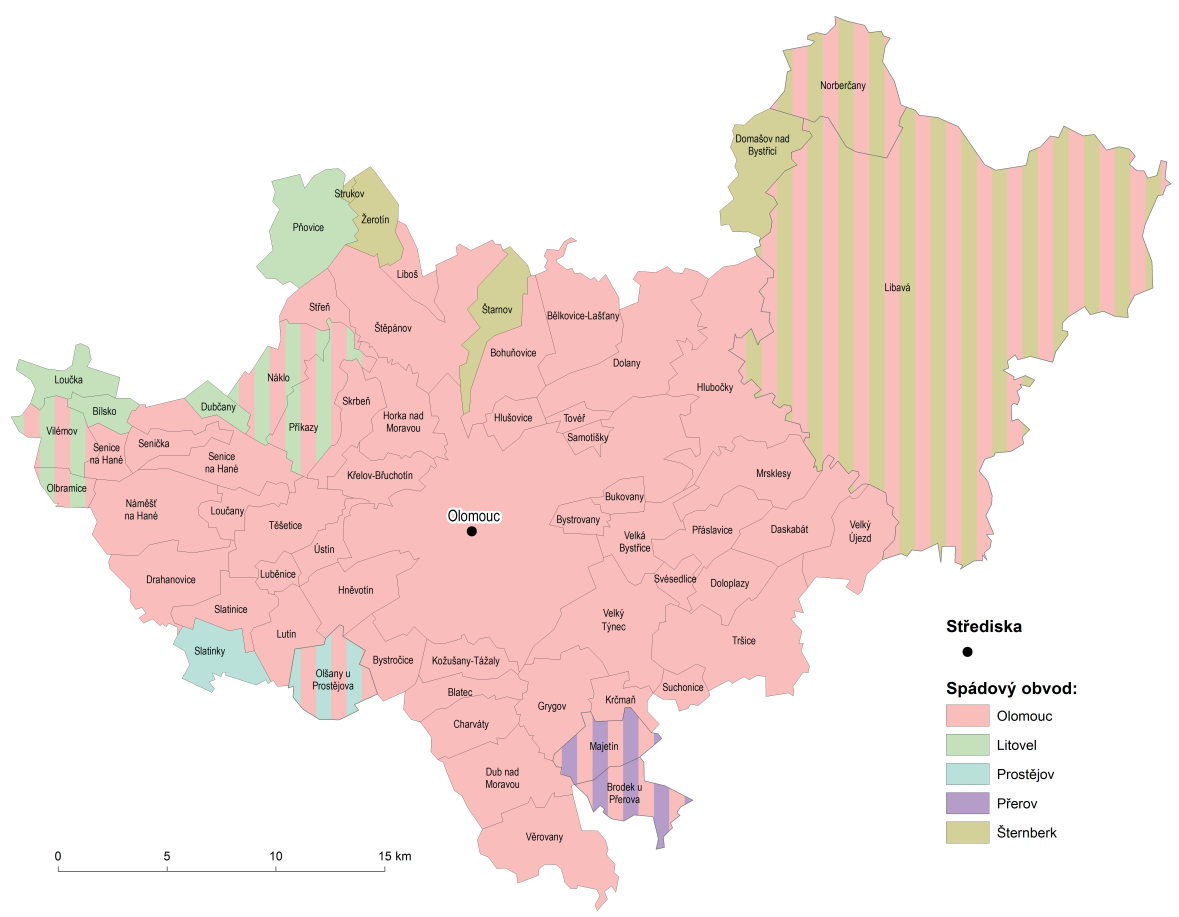

Zdroj: Šetření v Olomouci a jeho zázemí, podzim 2009. 


\subsection{Shrnutí}

Analýza dojížd'ky za službami v denním urbánním systému Olomouce potvrdila některé základní tendence vývoje sektoru služeb v transformačním období. Rozdílný byl hlavně vývoj veřejných a komerčních služeb. Komerční služby se postupně přizpůsobily poptávce, což znamenalo a znamená zlepšení vybavenosti (a tím i snížení dojižd'kové vzdálenosti) větších obcí v zázemí Olomouce především lékárnami, zařízeními poskytujícími běžné služby i pobočkami bank a pojištóven. Nákupy textilu a obuvi se naopak presunuly do velkých nákupních center, kde je v mnoha př́padech preferováno již i nakupování základních potravin. Větší či menší prodejny potravin zůstaly ve všech obcích regionu, $v$ některých prípadech se však jedná jen o večerky a maloplošné pultové prodejny, které mají omezenou nabídku a neodpovídají velikosti obce (např. v Bystrovanech).

Sít zařízení školních a zdravotnických služeb se v regionu měnila méně. Celková organizace prostoru i velikostní struktura obcí dávají dobré předpoklady, aby si všechna tato zařízení spravovaná místní, resp. regionální samosprávou zachovala svoji funkci a sloužila obyvatelstvu $v$ regionu obecně $i$ jeho menšinovým skupinám. Sít úplných základních škol a dojížd'ka do nich určuje nejvíce diverzifikovaný systém regionů na lokální úrovni. Jistým rizikem může být u veřejných služeb vstup soukromého sektoru do nemocničních zařizení v sousedících regionech (Šternberk, Prostějov, Přerov) - hovoříme zejména o riziku nahrazení základní zdravotní péče některými komerčními a finančně výnosnějšími zdravotnickými službami.

Při vymezení komplexních obslužných regionů, resp. přesněji v relaci spádový region Olomouce vs. oscilační regiony, je možné sledovat jejich značnou podobnost ve srovnání s vymezením obvodů ORP. V kontaktu s Prostějovem, Přerovem a Šternberkem je $v$ této relaci téměř shoda, $v$ kontaktu s Litovlí evidujeme tři obce z ORP Litovel (Senice na Hané, Senička a Střeň) absorbované obslužným vlivem Olomouce, a naopak obec Př́kazy z ORP Olomouc osciluje dojižd'kou za službami mezi Olomoucí a Litovlí.

Komplexní obslužní region Olomouce má zhruba 160 tisíc obyvatel. Ze 45 obcí mají dvě statut města, a to Olomouc a Velká Bystřice. Regiotvorný význam Velké Bystřice se ale v obslužné sféře neprojevil kvưli její okrajové poloze vedle vojenského újezdu Libavá. Kromě Olomouce jsou významnými zaměstnavateli v regionu Mora Moravia, s. r. o., Hlubočky, a Sigma Group, a. s., Lutín. I když se jedná o populačně velké obce (4 400, resp. 3200 obyvatel), ani jedna z nich se neprojevila jako významné obslužné středisko $v$ rámci regionu.

Město Olomouc tvoři dominantní jádro řešeného území, v němž se soustřed'uje jak správa území, tak mikroregionální občanská vybavenost, převážná část pracovních príležitostí, a koncentruje více než $60 \%$ celkového počtu obyvatel obslužného regionu. Zbývající část území nemůže mít ambici soupeřit se silou 
spádovosti Olomouce, ale zásluhou dobré dopravní dostupnosti naopak využívá výhody, které jí tato blízkost poskytuje. Zároveň městu vytváří zázemí v podobě zdroje pracovních sil, tradiční zemědělské produkce a možnosti odpočinku a rekreace. Pozitivním zjištěním je skutečnost, že ve větších obcích zůstala zachována občanská vybavenost a v dostupném okolí okrajových částí Olomouce jsou navíc lokalizována další mikroregionální centra. $V$ regionu se tedy prakticky nevyskytuje fenomén tzv. vnitřní periferie. 


\section{Modelování intra-urbánních nákupních pohybů obyvatelstva: príklad města Olomouc}

\subsection{Metodický př́stup}

Při studiu horizontálních interakcí, které organizují denní urbánní systémy (resp. funkční městské regiony), se spoléháme na dva zdroje dat, jež však mají omezené využití. Prvním zdrojem jsou statistická data zjištóvaná ve sčítání lidu, domů a bytů. $K$ jejich nevýhodám patří především desetiletý interval sledování, omezený druh sledovaných interakcí (dojižd'ka do zaměstnání a dojížd'ka do škol) a problém prostorových jednotek, za nichž jsou data dostupná. Druhým zdrojem dat je pak dotazníkové šetření, kde jsme schopni odstranit většinu problémů týkajících se dat ze sčítání lidu, nicméně některé mnohem závažnější problémy teprve vznikají. Máme na mysli především finanční a logistickou náročnost sběru takovýchto dat, vyloženě selektivní charakter z hlediska prostorového pokrytí daty a také určitý faktor subjektivity výzkumu a neporovnatelnosti dat z hlediska jejich kvality.

Existuje však i třetí možnost, jak se s analýzou interakcí v denních urbánních systémech či jejich částech vypořádat, která mnoho z výše uvedených nevýhod odstraňuje a jejiž omezení dosahují pouze takové úrovně, že lze tuto metodu považovat stále za oprávněnou. Touto možností je modelování prostorových interakcí. Modelování není závislé na charakteru základních prostorových jednotek, většinou vychází z běžně dostupných dat, Ize ho považovat za objektivní metodu, není finančně a logisticky náročné, nabízí variantní možnosti. Jednou z jeho největších výhod je, že kromě současného stavu dokáže predikovat i stav budoucí. K nevýhodám modelování pak patři především možnost nekorektní aproximace objektivně existující reality a určité její zjednodušení. Kalibrací modelů však můžeme tyto nevýhody snižit na přijatelnou úroveň.

Cílem této části studie je za pomoci modelování prostorových interakcí odhalit některé aspekty nákupního chování obyvatel města Olomouce. Zaměříme se především na intra-urbánní nákupní toky směřující do vybraných nákupních center poskytujících všeobecný sortiment (potraviny, zboží denní potřeby, oděvy, obuv, sportovní potřeby apod.). Nebudeme tedy brát v úvahu specializovaná nákupní centra (hobbymarkety apod.). V současné době jsou v Olomouci čtyři velká nákupní centra. Nejstarším z nich je Prior (dnes již Galerie Moritz), který se nachází v historickém jádru města a byl dokončen v roce 1982. V současné podobě byl otevřen na konci roku 2012. Zbývající tři nákupní centra vznikla během první poloviny první dekády nového století: Obchodní centrum Haná bylo otevřeno v roce 2002, Olympia v roce 2004 a Olomouc City v roce 2006. Všechna se 
nacházejí v rámci města v periferní poloze, Olympia dokonce již leží těsně mimo katastr města Olomouce. V únoru roku 2012 byla zahájena výstavba pátého nákupního centra Galerie Šantovka, které bude otevřeno koncem roku 2013. Její poloha je v kontaktu s historickým jádrem Olomouce. V souvislosti s touto výchozí situací si klademe následující výzkumné otázky:

- Jaká je současná modelovaná návštěvnost stávajících nákupních center?

- Jak ovlivní dokončení Galerie Šantovka návštěvnost nákupních center?

Abychom byli schopni na tyto otázky odpovědět, využijeme gravitační model s tou výhradou, že budeme zkoumat pouze toky odehrávající se uvnitř města, a rezignujeme tak na situaci v zázemí Olomouce.

Skupina modelů prostorových interakcí, v našem př́padě gravitačních modelů, se skládá ze čtyř variant: neomezený případ, př́pad s produkčním omezením, případ s atrakčním omezením a případ s produkčně-atrakčním (také dvojím) omezením (Wilson, 1974; Fotheringham, O’Kelly, 1989). Pro naše účely, kdy se zabýváme návštěvností nákupních center, poskytuje největší možnosti produkčně omezený gravitační model (příklady modelových studií uvádějí Fotheringham, O’Kelly, 1989; nebo Wilson, 2010). V zásadě tato varianta gravitačního modelu identifikuje způsob alokace nákupních toků z obytných zón k nákupním centrům za předpokladu, že známe počet toků vycházejících z obytných zón. Tato znalost hraje roli produkčního omezení, které Ize vyjádřit následujícím způsobem:

$$
O_{i}=\sum_{j} T_{i j}
$$

kde $O_{i}$ vyjadřuje celkový počet odchozích toků ze zóny $i$ směrem do nákupních center $j$.

Jestliže použijeme omezení definované rovnicí [1], pak můžeme produkčně omezený gravitační model vyjádřit takto:

kde:

$$
T_{i j}=A_{i} O_{i} w_{j} d_{i j}^{-\beta},
$$

$T_{i j}$ vyjadřuje intenzitu interakce mezi $i$ a $j$,

$A_{i}$ hraje roli balančního parametru,

$O_{i}$ vyjadřuje počet odchozích toků z obytných zón,

$w_{j}$ hraje roli zástupné proměnné vyjadřující atraktivitu obchodních center,

$d_{i j}^{j}$ označuje vzdálenosti mezi $i$ a $j$,

$\beta$ je parametr modelu, který kontroluje tvar křivky poklesu intenzity interakce se vzdáleností.

Balanční parametr $A_{i}$ zajištuje, že na produkční straně modelu je celkový počet odchozích toků z obytných zón modelem přesně reprodukován a úplně alokován k obchodním centrům. Nemůže tedy nastat situace, že některý odchozí tok není pririrazen $\mathrm{k}$ obchodnímu centru a naopak celkový počet příchozích toků do obchodního centra (tedy vlastně námi zkoumaná návštěvnost) nemůže být 
teoreticky vyšší, než je celkový počet odchozích toků v námi sledovaném prostorovém systému. Hodnotu balančního parametru pak vyjádříme za použití předchozí symboliky následovně:

$$
A_{i}=\left(\sum_{j} w_{j} d_{i j}^{-\beta}\right)^{-1} .
$$

\section{Proměnné vstupující do modelu}

Odchozí toky jsou sledovány v základních sídelních jednotkách (ZSJ), ty v modelu označujeme jako $i$. Jsou to nejmenší prostorové zóny, za které jsou ve sčítání lidu, domů a bytů 2001 dostupná použitá data, tedy počet samostatně hospodařících domácností (viz tabulka 11.4). Samostatně hospodařící domácnosti byly zvoleny jako masa na produkční straně modelu z prostého předpokladu, že nákupy se obvykle uskutečňují pro celou domácnost. Důležitým momentem je prostorová lokace mas, nebot' ZSJ mají plošný charakter, a pokud chceme spočítat vzdálenosti $\left(d_{i j}\right)$ mezi obytnými zónami a obchodními centry, potřebujeme, aby obě proměnné byly vztaženy $\mathrm{k}$ bodu. Zatímco $v$ prípadě obchodních center není jejich bodová prostorová lokace nikterak obtižná, v případě ZSJ jsme použili jako referenční body zastávky městské hromadné dopravy, které se nacházejí nejbliže ke geografickému středu zastavěné plochy té které základní sídelní jednotky. Z 82 základních sídelních jednotek města Olomouce jich 16 mělo méně než deset samostatně hospodařících domácností ( $v$ sedmi prípadech dokonce nula) - ty byly z dalších analýz vyloučeny. Do interakční matice a do matice vzdáleností pak tedy vstoupilo 66 základních sídelních jednotek.

Destinacemi $j$ byly v prvním kroku čtyři nákupní centra, později pak při modelování prognózy návštěvnosti pět nákupních center. $V$ tomto případě jsme však neměli žádné údaje o příchozích tocích, a byli jsme tedy nuceni použít zástupnou proměnnou $w$ na atrakční straně gravitačního modelu. Tou byla prodejní plocha nákupních center (viz tabulka 11.1).

Tab. 11.1: Prodejní plocha nákupních center

\begin{tabular}{|l|c|}
\hline Nákupní centrum & Prodejní plocha \\
\hline Obchodní centrum Haná & $37500 \mathrm{~m}^{2}$ \\
\hline Olympia & $30000 \mathrm{~m}^{2}$ \\
\hline Olomouc City & $24500 \mathrm{~m}^{2}$ \\
\hline Prior & $5000 \mathrm{~m}^{2}$ \\
\hline Galerie Šantovka & $46000 \mathrm{~m}^{2}$ \\
\hline
\end{tabular}

Zdroj: Internetové stránky developerů a prodejních řetězců.

Pozn.: * plánovaná prodejní plocha.

Poslední proměnná, která do modelu vstupuje, je vzdálenost mezi obytnými zónami (respektive zastávkami MHD) a nákupními centry. Testovali jsme tři typy vzdáleností: délkovou (euklidovskou) vzdálenost, časovou vzdálenost automobilem 
a časovou vzdálenost veřejnou dopravou. Poslední otázkou pak je hodnota parametru $\beta$ ve funkci poklesu intenzity interakce se vzdáleností. $V$ našem prípadě jsme použili negativní mocninnou funkci a testovali jsme čtyři hodnoty parametru $\beta(-1,00 ;-1,33 ;-1,66$ a $-2,00)$, který vyjadřuje odpor prostoru vůči sledované interakci. Haynes, Fotheringham (1984) tvrdí, že hodnota parametru $\beta$ se empiricky nachází mezi $-0,5$ a $-2,0$.

Závěrem je nezbytné učinit několik poznámek $\mathrm{k}$ aplikovanému gravitačnímu modelu a k prezentovaným výsledkům. Námi použitý model není čistě produkčně omezený, je spíše pseudoprodukčně omezený vzhledem ke statickému charakteru použitých dat na produkční straně modelu. Je zde však určitý a výše zmíněný předpoklad, že tento skalární údaj můžeme považovat za proměnnou interakční. Ze všech možností, které nám model poskytl (čtyři hodnoty parametru $\beta$ vs. tři typy vzdáleností), pak prezentujeme jen vybrané, př́ipadně se zaměříme pouze na drobné odlišnosti. Např́klad Fotheringham et al. (2000) považují za nejvýhodnější pro tento typ úlohy a intra-urbánní prostředí nastavit hodnotu parametru $\beta$ na $-1,0$, čehož se tedy v námi prezentovaných výsledcích taktéž držíme.

\subsection{Výsledky modelování}

Za výchozí situaci považujeme variantu modelu se čtyřmi stávajícími nákupními centry a časovou vzdáleností veřejnou dopravou (obrázek 11.1 a tabulky 11.2 a 11.3). Model ukazuje, že ze 43,6 tis. olomouckých domácností získává největší podíl Obchodní centrum Haná $(39,2 \%)$ následována Olympií $(25,5 \%)$, Olomouc City $(23,2 \%)$ a Priorem $(11,1 \%)$ - viz tabulka 11.2 . Tyto údaje se do vysoké míry shodují s podílem jednotlivých nákupních center na celkové prodejní ploše (viz tabulka 11.3). Detailní prostorový vzorec pak ukazuje obrázek 11.1. Distribuce je ovlivněna absolutní lokací nákupních center, relativní lokací vưči základním sídelním jednotkám a také velikostí prodejní plochy. V souladu s tímto zaznamenáváme nejvyrovnanější distribuci domácností mezi nákupní centra v př́padě centrálně položené základní sídelní jednotky „Olomouc - historické jádro“.

Tab. 11.2: Celková modelovaná situace (4 nákupní centra)

\begin{tabular}{|l|c|c|c|}
\hline Nákupní centrum & $\begin{array}{c}\text { Počet } \\
\text { domácností } \\
\text { na } \mathbf{~ m}^{\mathbf{2}}\end{array}$ & $\begin{array}{c}\text { Procento } \\
\text { z celkové } \\
\text { prodejní plochy }\end{array}$ & $\begin{array}{c}\text { Procento získaných } \\
\text { domácností z celkového } \\
\text { počtu domácností }\end{array}$ \\
\hline Obchodní centrum Haná & 0,45 & 38,7 & 39,2 \\
\hline Olympia & 0,39 & 31,0 & 26,5 \\
\hline Olomouc City & 0,42 & 25,2 & 23,2 \\
\hline Prior & 0,97 & 5,1 & 11,1 \\
\hline
\end{tabular}

Zdroj: Internetové stránky maloobchodních řetězců, vlastní výpočty. 


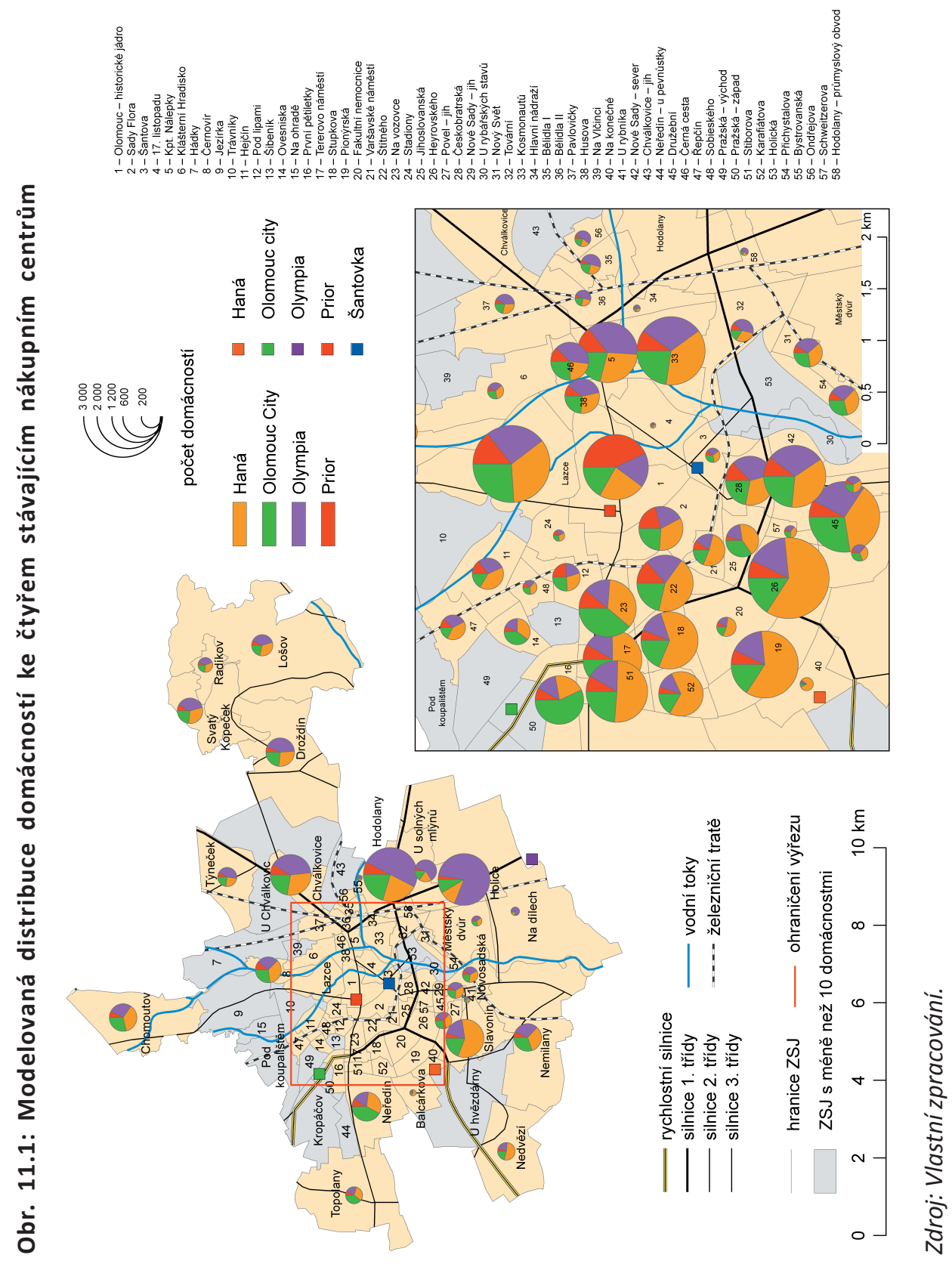


Situaci po dokončení Galerie Šantovka, tedy s pěti nákupními centry, ukazují obrázek 11.2 a tabulky 11.3 a 11.4, opět s časovou vzdáleností veřejnou dopravou. $V$ této situaci má model prediktivní charakter, a vyjadřuje tedy modelované budoucí nákupní chování olomouckých domácností. Otevření Galerie Šantovka podstatně změní celou situaci a také prostorový vzorec. Galerie Šantovka totiž podle výsledků modelu přitáhne $44,9 \%$ olomouckých domácností. S velkým odstupem pak následuje Obchodní centrum Haná $(22,1 \%)$ a s další ztrátou pak Olympia (14,3\%), Olomouc City (12,8 \%) a Prior (5,9 \%) - viz tabulka 11.3. V tomto prípadě se údaje o návštěvnosti shodují s podílem jednotlivých nákupních center na jejich celkové prodejní ploše méně než u výchozí situace, korelace je však stále významná.

Tab. 11.3: Celková modelovaná situace (pět nákupních center)

\begin{tabular}{|l|c|c|c|}
\hline Nákupní centrum & $\begin{array}{c}\text { Počet } \\
\text { domácností } \\
\text { na } \mathbf{~ m}^{2}\end{array}$ & $\begin{array}{c}\text { Procento } \\
\text { z celkové } \\
\text { prodejní plochy }\end{array}$ & $\begin{array}{c}\text { Procento získaných } \\
\text { domácností z celkového } \\
\text { počtu domácností }\end{array}$ \\
\hline Galerie Šantovka* & 0,42 & 32,4 & 44,9 \\
\hline Obchodní centrum Haná & 0,26 & 26,1 & 22,1 \\
\hline Olympia & 0,21 & 20,9 & 14,3 \\
\hline Olomouc City & 0,23 & 17,1 & 12,8 \\
\hline Prior & 0,51 & 3,5 & 5,9 \\
\hline
\end{tabular}

Zdroj: Internetové stránky maloobchodních řetězců, vlastní výpočty.

Pozn.: * Údaje pro plánovanou prodejní plochu.

Podívejme se nyní blíže na modelovanou predikci situace po otevření Galerie Šantovka ze dvou pohledů. První nám ukazuje vliv použité vzdálenosti v gravitačním modelu na interakční intenzity mezi jednotlivými základními prostorovými jednotkami a nákupním centrem Galerie Šantovka (viz obrázek 11.3). Ačkoliv tento pohled nepostrádá jisté aplikační dopady především v oblasti plánování veřejné dopravy, jeho význam je $v$ tomto případě především teoretický. $V$ následujícím odstavci se pokusíme oba aspekty okomentovat synteticky.

Za výchozí situaci, kdy nedochází k deformaci prostoru, lze považovat prostorový vzor využívající délkovou (euklidovskou) vzdálenost v modelu. Při prvním pohledu se tato situace neliší př́liš od prostorového vzoru využívajícího časovou vzdálenost veřejnou dopravou (MHD). Tato shoda je do značné míry dána centrální lokací Galerie Šantovka. Již zmíněné odlišnosti jsou pak dle našeho názoru způsobeny charakterem linkového vedení veřejné dopravy. $V$ prípadě Holice se modelovaná dostupnost Galerie Šantovka zhoršuje, naopak v př́padě Hejčína či 

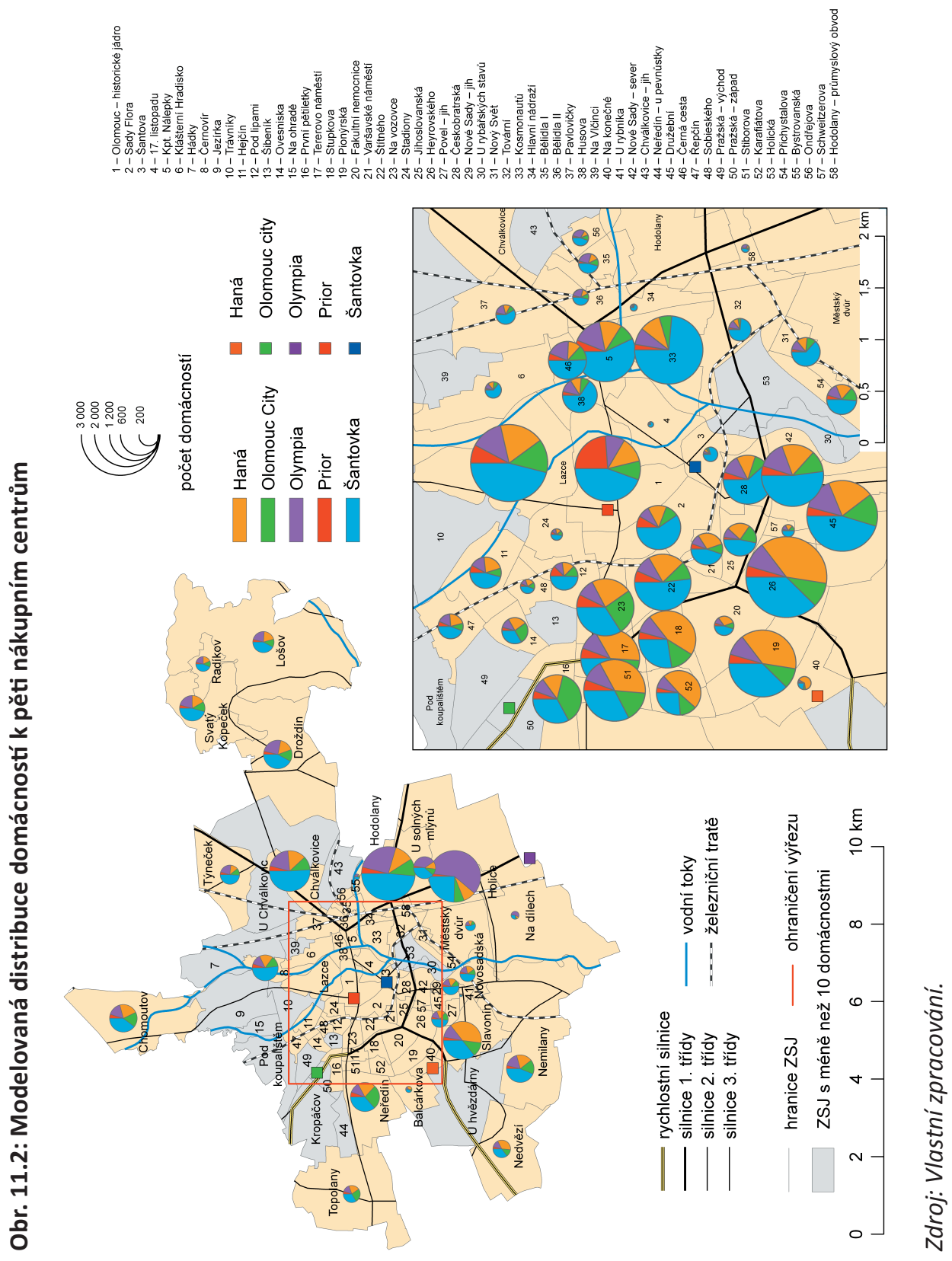


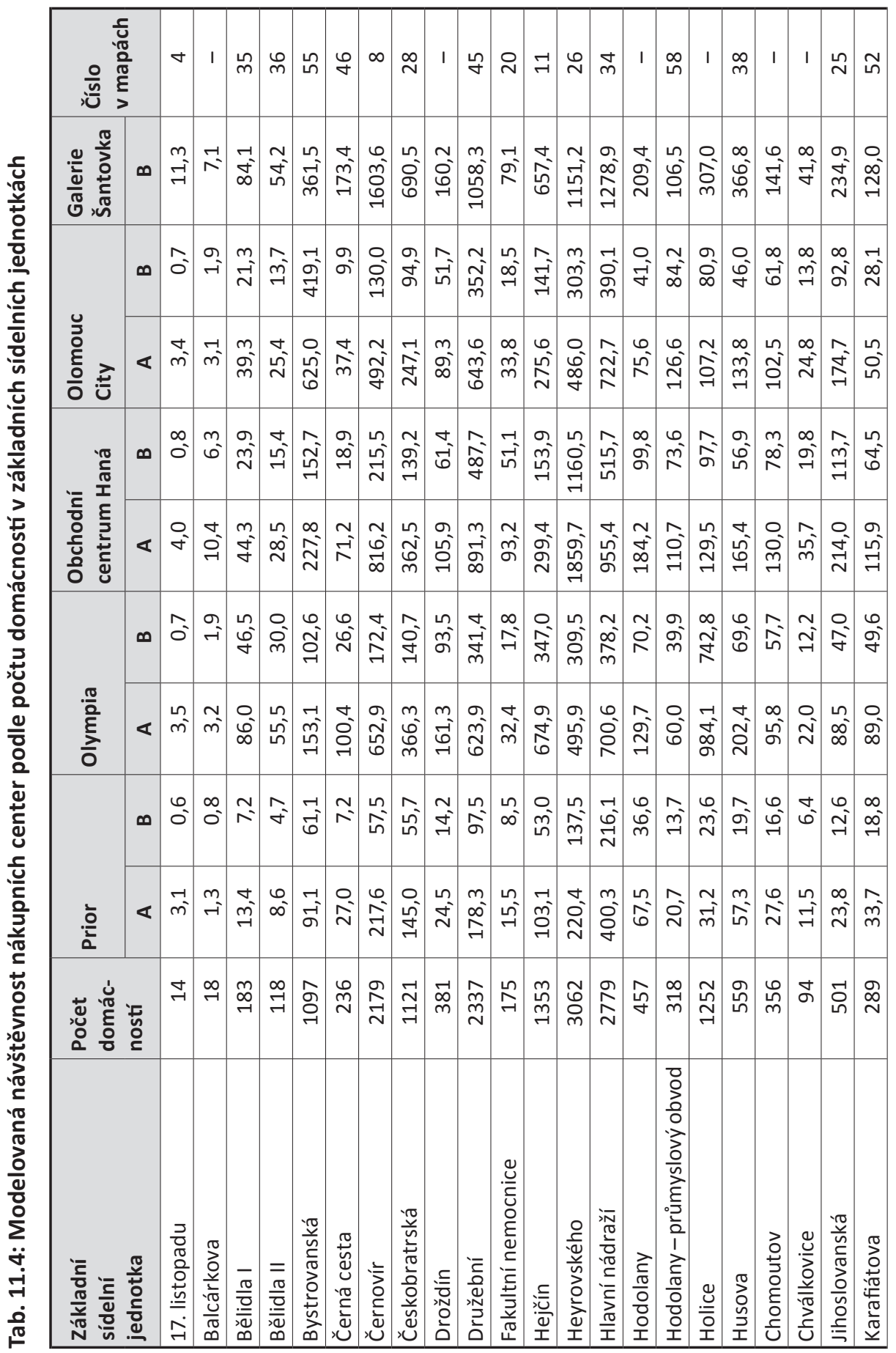




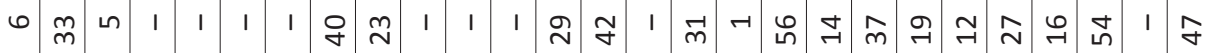

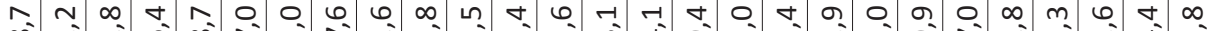

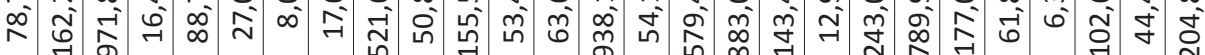

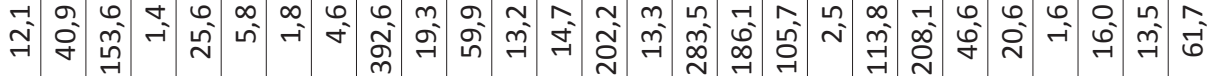

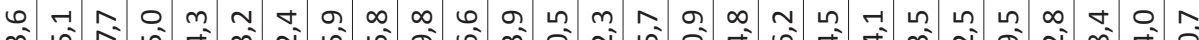

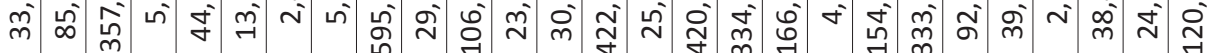
$m=m$ 年

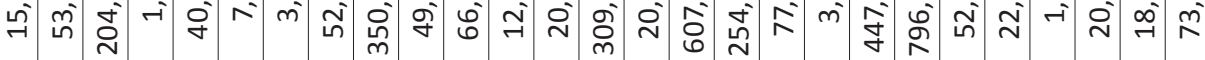

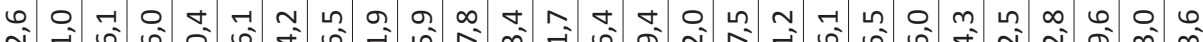
导孚

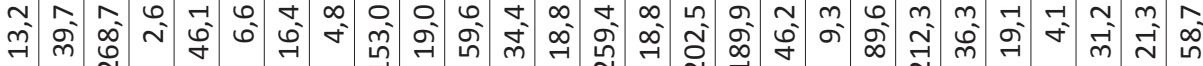

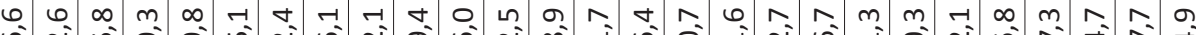
ம்

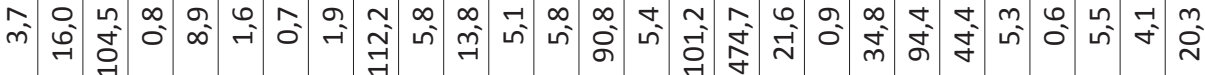

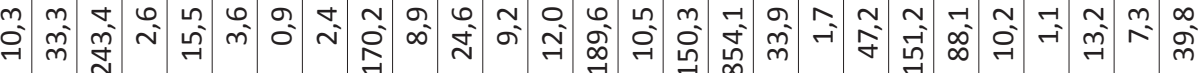

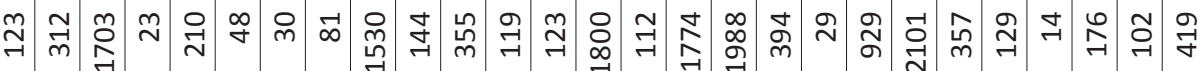

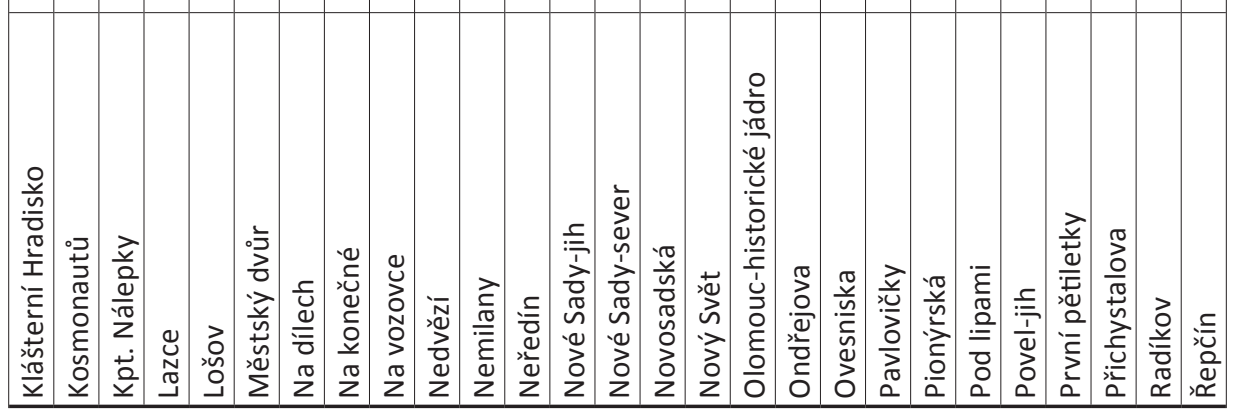




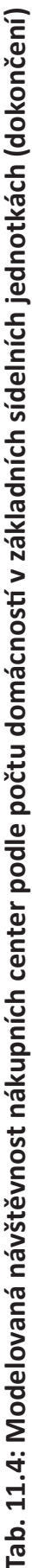

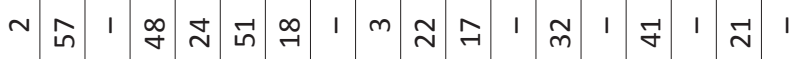

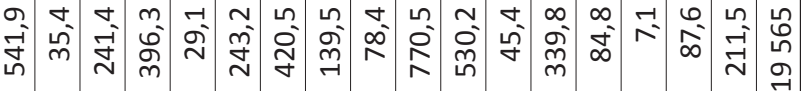

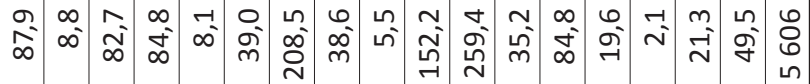

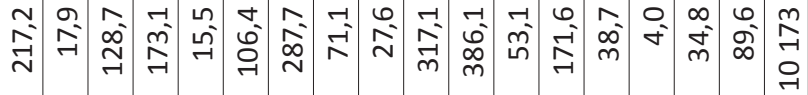

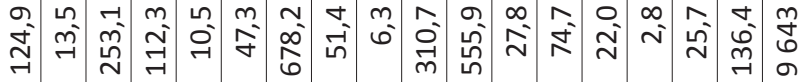

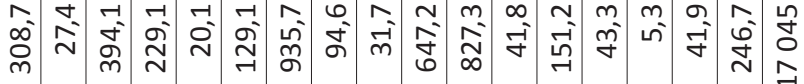

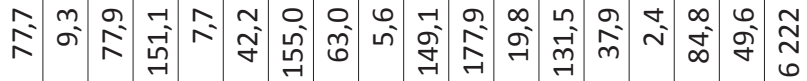

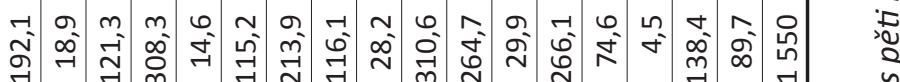

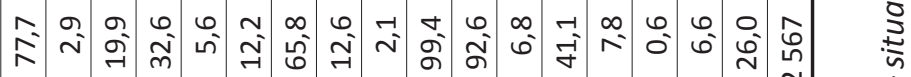

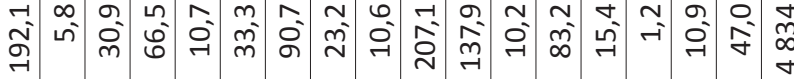

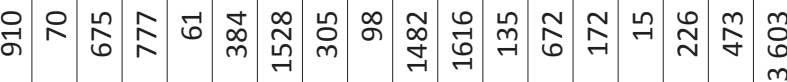

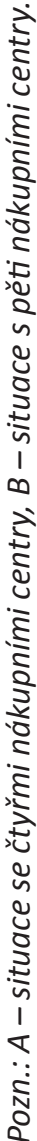




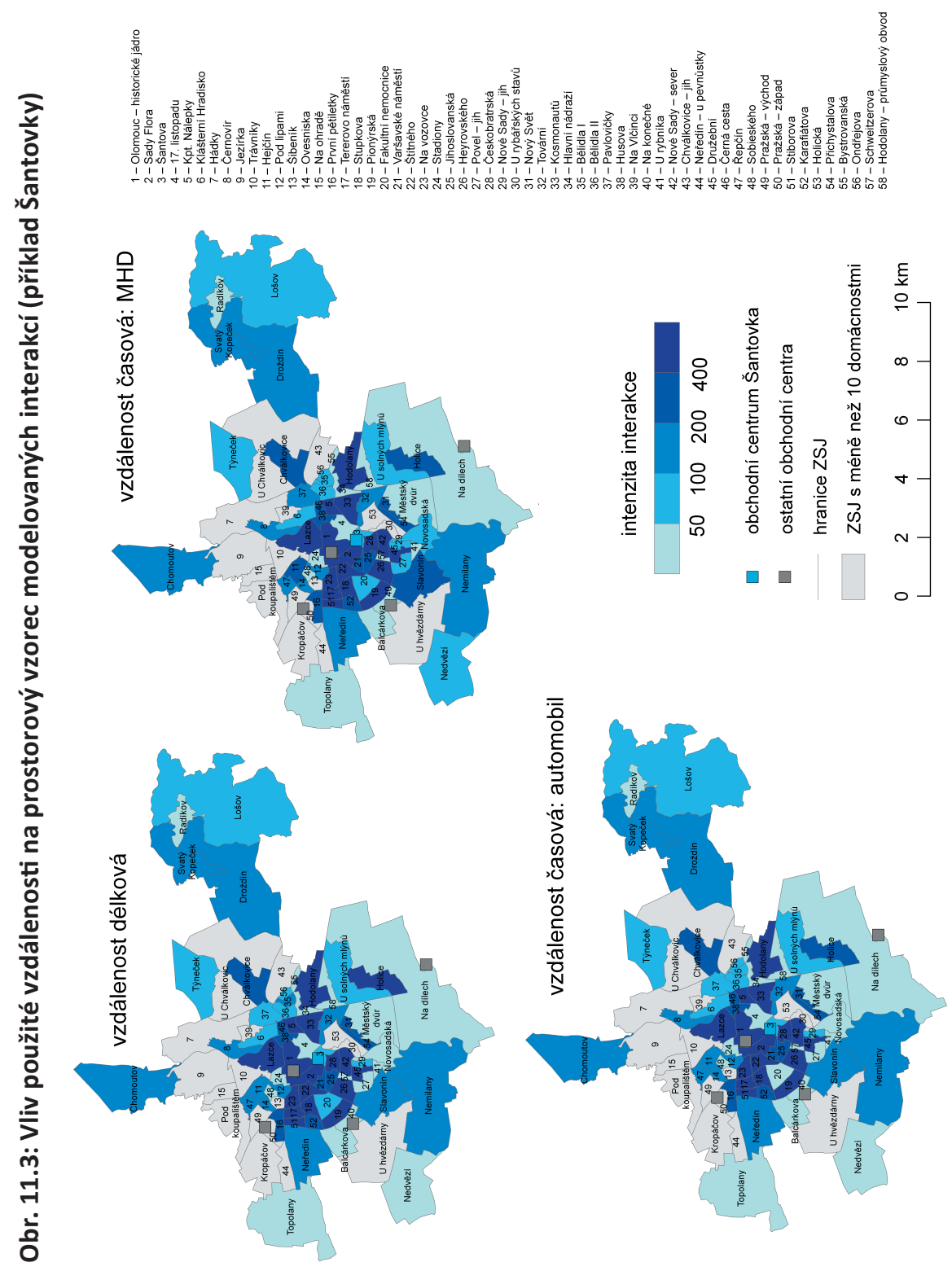

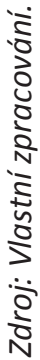


Pavloviček se zlepšuje. Podotýkáme, že v obou uvedených př́padech je počet domácností v základních sídelních jednotkách srovnatelný. Jinak totiž toto číslo podstatně ovlivňuje intenzitu interakce, jak je patrné např. u centrálně lokalizované základní sídelní jednotky „17. listopadu“ s pouhými 14 domácnostmi. Podobně malé jsou také odlišnosti mezi aplikací délkové vzdálenosti a časové vzdálenosti automobilem.

Zajímavé výsledky poskytuje pohled druhý (obrázek 11.4), který ukazuje jednak primární sféry vlivu (dále i spádové oblasti) čtyř existujících nákupních center, jednak procentuální úbytek prostorových nákupních preferencí domácností v základních sídelních jednotkách ve prospěch Galerie Šantovka. V prípadě primárních spádových oblastí stávajících nákupních center ještě zůstaňme také u problematiky zvolené vzdálenosti. Za primární spádovou oblast považujeme ty základní sídelní jednotky, ze kterých modelově do daného nákupního centra dojíždí nejvíce domácností.

Ve všech třech případech (vzdálenost délková, časová veřejnou dopravou a časová automobilem) má největší spádovou oblast Obchodní centrum Haná, následovaná Olympií. Primární spádová oblast nákupního centra Olomouc City je o poznání menší, navíc se podstatně liší podle zvolené vzdálenosti. Podobné rozdíly jsou patrné i na hranici sfér vlivu Hané a Olympie, kdy jmenovitě upozorňujeme na ZSJ „Českobratrská“ a variantu s časovou vzdáleností veřejnou dopravou. Tato ZSJ tvoři exklávu sféry vlivu Olympia, poněvadž s ní má jako jedna ze dvou ZSJ prímé spojení kyvadlovou dopravou. Co se týče Prioru, jeho primární sféra vlivu je pouze ZSJ "Olomouc - historické jádro“, v př́padě časové vzdálenosti automobilem si dokonce toto nákupní centrum svoji sféru primárního vlivu vůbec nevytvoří.

Po dokončení Galerie Šantovka Ize na základě modelu předpokládat, že všechna stávající nákupní centra ztratí více než polovinu teoreticky přitahovaných domácností (Obchodní centrum Haná 56,6 \%, Olomouc City 55,1 \%, Olympia $53,9 \%$ a Prior 53,1\%). Prostorový vzorec ztrát návštěvnosti stávajících nákupních center ve prospěch Galerie Šantovka je uveden na obrázku 11.4 a opět se liší podle zvolené vzdálenosti, kdy se znovu projevuje různá dostupnost lokace Galerie Šantovka daná bud' délkovými, nebo časovými jednotkami vzdálenosti. 


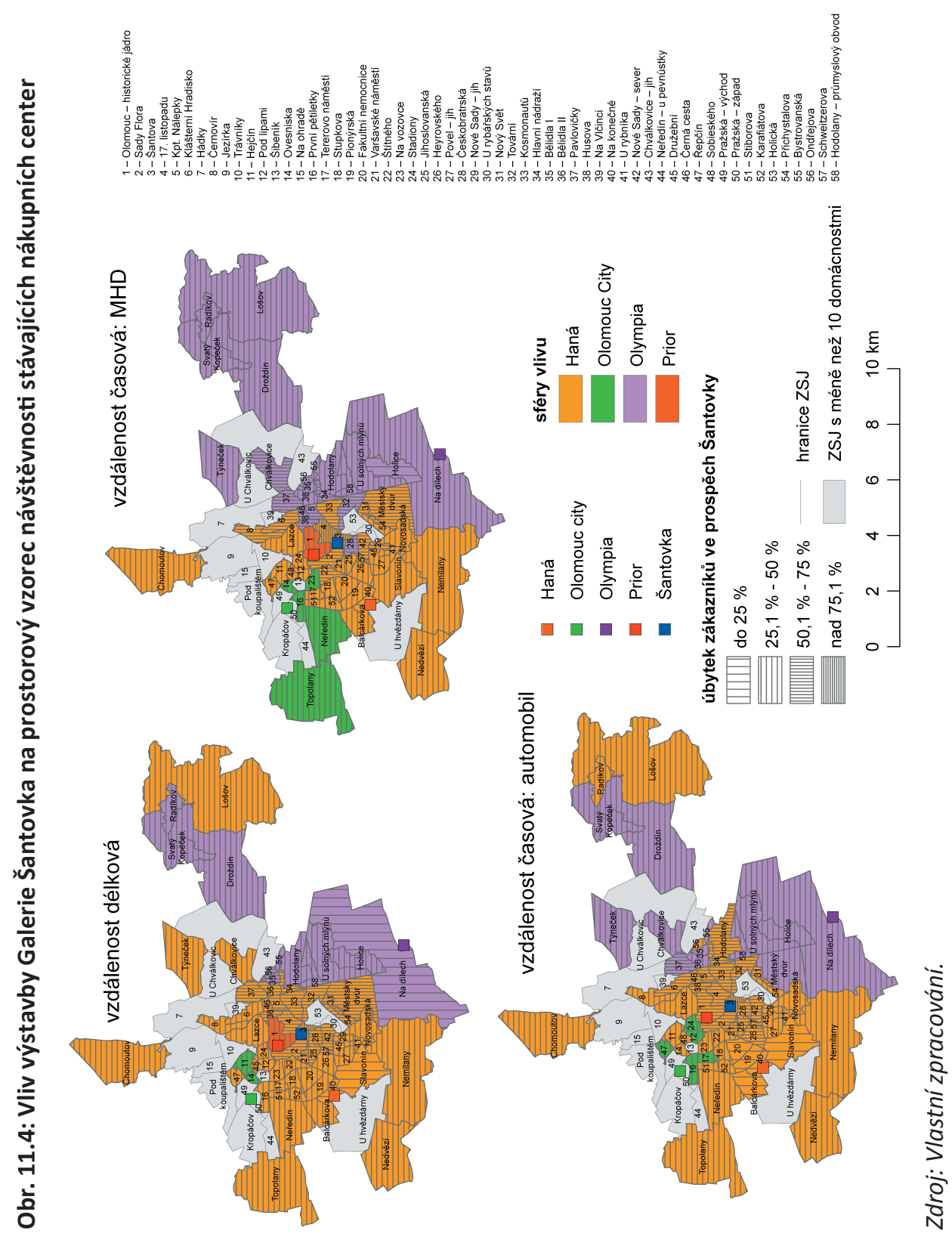




\subsection{Shrnutí}

Není překvapující, že v naší aplikaci gravitačního modelu hrála zásadní roli lokace nákupních center a jejich relativní poloha vưči základním sídelním jednotkám města Olomouce. Tento fakt je naprosto zřejmý z tabulek 11.2 a 11.3 ze sloupců s daty o využití prodejní plochy jednotlivých nákupních center k poměru přitažených domácností. Toto relativní číslo je totiž v obou případech nejvyšší u nákupního centra Prior, který dosud v našich analýzách nevykazoval dobré výsledky z hlediska úspěšnosti v oblasti návštěvnosti.

Při situaci se čtyřmi centry dosáhl Prior výsledku 0,97 domácností/m², při situaci s pěti centry pak 0,51 domácností/ $\mathrm{m}^{2}$. I když se jedná o největší pokles daného ukazatele (Galerie Šantovka s největší prodejní plochou je taktéž centrálně lokalizovaná), ostatní nákupní centra se pohybovala mnohem níže - nejhorší Olympia situovaná mimo katastr města Olomouce dosáhla v případě čtyř nákupních center hodnoty 0,39 domácností/ $\mathrm{m}^{2}$, v prípadě pěti nákupních center pak 0,21 domácností/m². Galerie Šantovka v predikci dosáhla druhé nejvyšší hodnoty 0,42 domácností/ $\mathrm{m}^{2}$.

Z hlediska úspěšnosti investic do nákupních center se tedy v případě Olomouce jednoznačně jeví jako nejvýhodnější centrální lokace (Prior), resp. revitalizovaná brownfields (Galerie Šantovka), než dřívější periferní a suburbánní lokace na zelené louce. V případě Prioru je nezbytné poznamenat, že je již v současnosti zrekonstruován a nově otevřen pod názvem Galerie Moritz s větší prodejní plochou, než která vstupovala do našeho modelu. Modelované výsledky tohoto nákupního centra by tedy v současnosti byly ve sledovaném parametru ještě lepší.

Z hlediska metodologického Ize konstatovat, že aplikace produkčně omezeného gravitačního modelu poskytla odpovědi na otázky kladené na začátku této studie a že se při nedostatku dat a náročnosti jejich zjištování jeví metody modelování prostorových interakcí jako životaschopné, pokud jsou výchozí situace a výsledky interpretovány korektním způsobem. Zde máme na mysli především vytržení území města Olomouce z okolního prostorového kontextu, kdy by například nákupní centrum Olympia lokalizované v blízkosti dálniční křižovatky vykazovalo lepší výsledky ve sledovaných parametrech. 


\section{Závěrečné shrnutí}

Český maloobchod prochází obdobím největších změn v celé své historii. Na kapacitní i kvalitativní nedostatečnost odvětví z konce 80. let minulého století navázala v první polovině let devadesátých etapa atomizace, podpořená malou privatizací, kdy se počet maloobchodních jednotek za deset let zvýšil dvojnásobně na téměř 100 tisíc. Od 2 . poloviny 90 . let začaly ve větší míře pronikat na tuzemský trh zahraniční řetězce a český maloobchod se velmi rychle internacionalizoval. Vstup zahraničního kapitálu byl dominantní, domácí společnosti a podniky nebyly reálně konkurenceschopné (Szczyrba, 2005). Pokračovala transformace maloobchodní sítě, jejiž sítová struktura se opírala o stále větší počet velkoplošných maloobchodních jednotek (super- a hypermarkety, diskonty), objevila se první nákupní centra.

Charakteristickým rysem českého trhu se stala poměrně výrazná časová posloupnost procesu rozvoje jednotlivých velkoformátových prodejních konceptů. Za prvních deset let ekonomické transformace byly českou společností velmi rychle akceptovány prakticky všechny moderní velkoplošné prodejny, a to v pořadí supermarkety, diskonty, hypermarkety a nákupní centra (Szczyrba et al., 2007). Český maloobchod se stal vysoce konkurenčním odvětvím, na němž nebylo místo ani pro některé zavedené mezinárodní firmy, jež byly nuceny odejít (Carrefour, Julius Meinl a další). Probíhá další koncentrace odvětví a roste podíl prodejů realizovaných největšími společnostmi. $V$ posledních zhruba 5-6 letech dochází ke konsolidaci maloobchodního trhu, který charakterizuje menší dynamika růstu největších obchodních firem a jejich současné další posilování tržních pozic.

Dojižd'ka či docházka za obchodem a službami, resp. nákupy a aktivitami volného času, je běžnou součástí života obyvatel naší společnosti. Její frekvence se odvíjí jak od pravidelných lidských potřeb, tak od možností volně nakládat s materiálními prostředky a využívat svůj volný čas. Posledních dvacet let vývoje české společnosti přineslo velké změny v pohledu na průběh a formu nakupování, využívání služeb a trávení volného času. Dříve unifikované nákupní zvyklosti a chování doznaly tak razantních změn, že se tyto odrazily v celkovém prístupu ke kulturním návykům napříč všemi generacemi.

Řada provedených výzkumů potvrdila, že typickou je nejen běžná forma denních nákupů základních potravin v malých neřetězcových prodejnách, ale určitým standardem se stala i denní dojižd'ka za nákupy do specializovaných maloobchodních řetězců (nákupních center), jež svou agresivní cenovou politikou oslovují stále více zákazníků a vytlačují drobné prodejce na okraj trhu. Tato dojížd'ka je často provázaná s dojižd'kou do zaměstnání, škol či za jinými službami. 
Stále více však denní cesta za nákupy získává u obyvatel (nejen městských aglomerací) prioritu v jejich rozhodování, což dotvárí stále silnější vazby v rámci denního urbánního systému. Rozhodující intenzita však přestává být ve vazbě jádro - zázemí a přesouvá se do prostoru zázemí - příměstská zóna, kde jsou největší nákupní centra, retail parky, hypermarkety, hobbymarkety a další prodejní koncepty ponejvíce lokalizovány, kde se začínají utvářet nová uzlová (sekundární) centra maloobchodu, služeb a volnočasových aktivit.

Nákupní centra a retail parky dnes neslouží zdaleka pouze k účelům samotného nákupu, ale svým charakterem vybízejí a podněcují zákazníky $k$ zábavě a trávení volného času. Nákupní centra však nejsou atraktivní pouze pro nákup základního sortimentu, celodenní návštěva nákupního centra spojená s nákupem nejen potravin, drogerie, ale i oděvů, obuvi, kosmetiky, sportovního zboží, knih atd., obědem a zábavou není výjimkou. Zákazníkům jsou nabízeny i další služby jako restaurace, kadeřnictví, čistírny, lékárny, banky apod., mladou a střední generaci silně oslovují magnety typu multikina či imaxu a řada možností sportovnězábavního vyžití (fitness, bowling, bruslení, lezecké stěny a další), což jsou lákadla k neopuštění prostoru nákupního centra. Do nákupních center vyjiždí za nákupem, službami a zábavou již zhruba polovina populace (Kunc et al., 2012d).

Zde nelze uvažovat každodenní aktivitu, pro některé populační skupiny, častěji patrně z příměstských zón a venkovských suburbií, se však uvedený způsob chování stal určitým volitelným standardem, a to nejčastěji víkendovým (rodiny $s$ dětmi, ale i mládež). Zejména mladým lidem nejde $v$ mnohých prípadech o vlastní nákup, ale o společenskou potřebu o možnosti nákupu uvažovat, podělit se o ni s vrstevníky, a priitom se pohybovat v prostředí, které tu možnost vytvárí - být vidět a být „in“ $v$ zavedeném nákupním centru (Underhill, 2004; Spilková, 2012b). Navíc mají možnost vzhledem $\mathrm{k}$ převažující pracovní neaktivitě investovat svůj volný čas i do běžného pracovního dne.

Centra českých měst jsou v posledních letech vystavena stále sílícímu tlaku komercionalizace, jejímž jedním z projevů je vytlačování prodejen potravin právě z center (Sýkora, 2001; Poole et al., 2002; Mulíček, Osman, 2009). Klesá ovšem i prodejní plocha specializovaných nepotravinářských obchodů, přičemž těžiště nákupů potravin i nepotravinářského sortimentu se přesouvá do sídlištních zón a na městskou periferii, kde jsou lokalizovány supermarkety a hypermarkety, často jako součást nákupních center či retail parků.

Na druhou stranu vznikla $v$ centrech měst $v$ posledních letech řada malých specializovaných obchodů zaměřených na (bio)potraviny, „značkové“ sýry a uzeniny, cukrovinky, řemesInné dílny apod., prosazují se restaurace nabízející kulinářskou kvalitu i př́jemné prostředí (Kunc et al., 2012e). Některé maloobchodní řetězce se do center měst vracejí a cílí na pěšky se pohybujícího zákazníka vracejícího se z práce, přestupujícího na MHD s potřebou rychlého nákupu, a to v podobě menších supermarketů (Albert, Billa a další) či nových konceptů (např. 
Tesco Expres). Také developeři na centra měst nezanevřeli, v řadě měst České republiky se chystají stavět a otevírat další specializovaná nákupní centra či multifunkční komplexy, jejichž součástí bude nákupní pasáž. Na atraktivitě získávají zejména centrálně lokalizované, uvolněné a nevyužívané prostory a objekty (Kunc et al., 2012a, 2012e). Lidé a potenciální zákaznící se budou v centrech měst pohybovat i nadále, je ovšem otázkou, jakým způsobem je sem přilákat a hlavně udržet. Maloobchod by v této snaze měl sehrávat nezastupitelnou roli.

Na změny nákupního chování měla a stále má významný vliv také (ale nejen) současná hospodářská recese. Ta vede zákazníky k opatrnosti, větším úsporám a menšímu plýtvání s potravinami. Lze hovořit o racionalitě nakupování a spotřeby. Omezuje se impulzivní styl nakupování podpořený reklamou, lidé častěji napřed přemýšlejí, co a proč chtějí koupit. Druhým výrazným trendem je orientace na kvalitu a hodnotu. Denní nákup čerstvých potravin a rostoucí podíl nákupů kvalitního značkového a levnějšího zboží v akcích a promocích je toho důkazem. Hodnotné zboží a služby si již ted' vytvářejí potenciál získávat v pokrizovém období stále více zákazníků.

Budoucí zákazníci dnes vyrůstají v internetovém prostředí, které povede k aktivnímu vyžadování a sledování vybraných informací. Rozhodujícím faktorem pro uskutečnění nákupu bude relevantní elektronická komunikace mezi prodejcem a zákazníkem, která bude vyžadovat jednoduchost a přímočarost. Nákupní chování se posune od pasivity $k$ aktivitě, od prijímání k vyhledávání. Obchod patří aktuálně $k$ technologicky nejrychleji se rozvíjejícím odvětvím a v horizontu několika let Ize očekávat několik zásadních inovací. Změní se především vlastní nákupní proces, který kromě současných standardních a samoobslužných pokladen nabídne daleko více možností (mutichannel retailing). Postupně bude odstraněna nutnost zadávat při nákupu platební kartou PIN kód (bezkontaktní platební karty), jak se již děje v současnosti. Prostřednictvím prohližečů (smartphone, tablet) se rozšírí příprava doma, zákazník si předem vybere zboží, označí, naskenuje a obchodník mu ho připraví k odběru nebo rovnou doveze domů. Rozširíi se forma virtuálních regálů, které jsou již dnes ve vybraných obchodech $\mathrm{k}$ dispozici. Důraz bude také kladen mimo jiné na udržitelnost a šetrnost $k$ životnímu prostředí, preferováni budou ověření výrobci a kvalitní lokální produkty. 


\section{Final conclusion}

Czech retail trade has been undergoing a period of greatest changes in all of its history. The capacity and quality insufficiency of the sector at the end of the 1980s was followed in the early 1990 s by a stage of atomization incited by small-business privatization; the number of retailing units grew twofold to almost 100,000 within this period. Foreign retail chains started to penetrate the domestic market in the second half of the 1990s and the Czech retail trade has rapidly become internationalized. Foreign capital entry was dominant; domestic companies and businesses were not actually able to compete (Szczyrba, 2005). The retailing network transformation continued - its network structure was based on increasingly larger numbers of large-scale retailing units (super and hypermarkets, discount shops); the first shopping centers appeared.

A rather singular time sequence of the individual large-scale retailing concepts development process has become a characteristic feature of the Czech market. During the first ten years of the economic transformation the Czech society had readily accepted virtually all modern large-scale shops in the following sequence: supermarkets, discount shops, hypermarkets and shopping centers (Szczyrba et al, 2007). Czech retail trade has become a highly competitive field, where several established international companies could not find their place and were forced to leave (Carrefour, Julius Meinl and others). Further sector concentration has been under way and there has been growing the share of sales realized by the largest companies. The retail market has been consolidating for the past 5-6 years; this period has been characterized by a slower dynamics in the growth of the largest companies and continued strengthening of their market positions.

Commuting or walking for commerce and services, i.e. shopping and leisure time activities, has become a normal part of our lives. Its frequency is based both on regular human needs and on the possibility to use the available material resources and free time. The past twenty years of the Czech society's development have resulted in large changes in an attitude towards the process and form of shopping, using services and spending leisure time. Formerly unified shopping customs and behavior have been so greatly modified that they became reflected in the general approach towards cultural habits across all generations.

A number of performed surveys confirmed that the common daily shopping for basic foodstuffs in small non-chain shops is a typical feature and also that daily commuting for shopping to specialized retail chains (shopping centers), whose aggressive pricing policy has been addressing ever increasing numbers of customers and pushing small-scale retailers to the edge of the market, have also 
become a kind of standard feature. This commuting is frequently a part of commuting to work, schools and for other services. The daily trips for shopping have been acquiring increasing priority in the decision making processes of the inhabitants (not only of city agglomerations); this supports shaping ever stronger bonds within the daily urban system. The decisive intensity ceases to be in the center-hinterlands bond and it has transferred into the hinterlands-suburban zone space, where the largest shopping centers, retail parks, hypermarkets, hobby markets and other retailing concepts are mostly located and where the establishment of new nodal (secondary) centers of retail trade, services and leisure time activities has been observed.

Shopping centers and retail parks do not currently serve just the purpose of shopping itself; their features invite and incite the customers to enjoy themselves and spend their leisure time. Shopping centers are not attractive only for basic goods shopping, though - whole day visits to shopping centers connected with shopping for foodstuffs, drugstore goods, clothes, shoes, cosmetics, sports equipment, books, etc. and connected also with a lunch and entertainment are no exceptions. Customers are offered also additional services, such as restaurants, hairdressers, cleaning services, pharmacies, banks, etc., young and middle generations are strongly attracted by multiplex cinemas, IMAX cinemas and also by a number of sports-entertainment facilities (fitness, bowling, skating, climbing walls, etc.) that entice customers not to leave the space of the shopping center. About a half of the total population travel to shopping centers for shopping, services and entertainment (Kunc et al., 2012d).

This is not an everyday activity, yet for some population groups, coming more frequently from the suburban zones and rural suburbs, the above-specified behavior has become a kind of optional standard, mostly enjoyed on weekends (families with children and the youth). Young people, specifically, are frequently not really interested in the shopping itself; for them such a visit is a social need when they can think about shopping, share experience with their peers and be in an environment that brings such an opportunity - to be seen, to be in an established shopping center (Underhill, 2004; Spilková, 2012b). Moreover they can, due to their prevailing labor inactivity, spend their leisure time also during a common working day.

Czech inner cities have been exposed to an ever growing commercialization pressure in recent years and driving of grocery stores out of the inner cities is one of the manifestations of this process (Sýkora 2001; Poole et al., 2002; Mulíček, Osman, 2009). You can also observe shrinking of the specialized non-foodstuffs shops floorspace, while the center of gravity for both foodstuffs and nonfoodstuffs shopping has been transferring to the housing development zones and to the city periphery where you can find supermarkets and hypermarkets, which are frequently parts of shopping centers. 
On the other hand many small specialized shops have recently opened in the inner cities; these mostly offer (bio)foodstuffs, „,brand“ cheeses and meat products, confectionery, crafts shops, etc. and you can increasingly come across restaurants offering high food quality and nice environment (Kunc et al., 2012e). Some retail chains have returned to inner cities and target moving customers returning from work, waiting for public transportation connections and needing to do some quick shopping; smaller supermarkets (Albert, Billa, etc.) and new concepts (e.g. Tesco Express) have appeared for this purpose. Developers do not avoid inner cities either; in several Czech cities they plan to build and open additional specialized shopping centers and multifunctional complexes including shopping arcades. Vacated or unused spaces and buildings located in inner cities have been ever more attractive (Kunc et al., 2012a, 2012e). People and potential customers will keep moving within inner cities; there arises a question, though, how to attract them and keep them there. Retail trade should play a key role in this effort.

Shopping behavior has been significantly influenced by the current economic crisis. This crisis encourages customers to be more cautious, preserve their savings and waste foodstuffs less. You could call it rationality in shopping and consumption. The spontaneous way of shopping incited by advertising has declined - people first think about what and why they want to buy. Focus on quality and value is the second distinct trend. This is demonstrated by daily shopping for fresh foodstuffs and growing share of purchases of high-quality brand products and cheaper products on sale. Valuable products and services have been establishing a potential for acquiring growing numbers of customers in a post-crisis period.

Future customers grow up in the Internet environment, which will result in their active requesting and monitoring of selected information. Relevant electronic communication between the seller and the customer will be the decisive factor for purchase realization and this communication will have to be based on simplicity and directness. Shopping behavior will move from passivity to activity, from receiving to searching. Commerce currently belongs among the technologically fastest developing branches and you can expect several crucial innovations within a few years. The greatest changes can be expected in the shopping process itself, which will offer many more options (multichannel retailing) besides the current standard and self-service cash desks and check-out points. The need for entering a PIN while making a purchase (contactless payment cards) will be removed; you can see this trend even today. Using various browsers (smartphone, tablet) the customers will improve their home preparation; they will select the goods, mark them, scan them and the seller will prepare the goods for pick-up or transport them to the customer. Virtual shelf stands will expand - you can see them in selected shops even today. Sustainability and environmental friendliness will be emphasized; verified manufacturers and high-quality local products will be preferred. 


\section{Použitá literatura}

Anděl, J., Bičík, I. (1980): K některým problémům geografické mobility obyvatelstva. Acta Universitatis Carolinae, Geographica, Supplementum 15: 149-159.

Andráško, I., Biolek, J. (2011): Rezidenční suburbanizace v ČR a její společenské dopady. In Andráško, I., Ira, V., Kallabová, E. (eds.): Časovo-priestorové aspekty regionálnych štruktúr ČR a SR. Bratislava: Geografický ústav SAV: 12-17, 6 Alonso, W. (1978): A Theory of Movement. In Hansen, N. M. (ed.): Human

Settlement Systems: International Perspectives on Structure, Change and Public Policy. Cambridge (Mass.): Ballinger: 197-211.

Bacon, R. W. (1995): Combined Trips and the Frequency of Shopping. Journal of Retailing and Consumer Services 2 (3): 175-183.

Baray, J., Cliquet, G. (2007): Delineating store trade areas through morphological analysis. European Journal of Operational Research 182: 886-898.

Bartáková, I. (2010): Spádovost za službami na Vyškovsku. [Diplomová práce]. Brno: Masarykova univerzita.

Bauman, Z. (1996): From Pilgrim to Tourist - or a Short History of Identity. In Hall, S., du Gay, P. (eds.): Questions of Cultural Identity. London: Sage: 18-36.

Bauman, Z. (1998): Globalisation: The Human Consequences. Political Geography 20 (1): 117-119.

Bauman, Z. (2007): Consuming life. Cambridge: Polity Press.

Bäckström, K. (2006): Understanding Recreational Shopping: A New Approach. International Review of Retail, Distribution and Consumer Research 16 (2): 143-158.

Berry, B. J. L. (1967): Geography of Market Centres and Retail Distribution. New Jersey: Prentice Hall, Englewood Cliffs.

Berry, B. J. L. (1973): Growth centres in the American urban system. Cambridge: Mass. Bezák, A. (2000): Funkčné mestské regióny na Slovensku. Geographia Slovaca 15: 1-89.

Birkin, M., Clarke, G., Clarke, M. 2002: Retail Geography \& Intelligent Network Planning. Chichester: Wiley.

Biolek, J., Andráško, I. (2012): Rezidenční suburbanizace v zázemí největších měst Olomouckého kraje. In Andráško, I., Dvořák, P., Ira, V. (eds.): Časoprostorové změny regionálních struktur ČR a SR. Brno: Ústav geoniky AV ČR, s. 5-11.

Bračok, F. (2011): Spádovost za službami ve vybraném regionu. [Diplomová práce]. Brno: Masarykova univerzita.

Brown, S. (1991): Retail Location: The Post Hierarchical Challenge. The International Review of Retail, Distribution and Consumer Research 1 (3): 367-381. 
Butler, R. W. (1991): West Edmonton Mall as a Turist Atraction. The Canadian Geographer 35 (3): 287-295.

Centers DATA (2010): Retail Book. Praha: Centers Publishing, s. r. o.

Clark, G. L., Feldman, M. P., Gertler, M. S., Williams, K. (2003): The Oxford Handbook of Economic Geography. New York: Oxford University Press.

Cleveland, M., Babin, B. J., Laroche, M., Ward, P., Bergeron, J. (2003): Information Search Patterns for Gift Purchases: A Cross-national Examination of Gender Differences. Journal of Consumer Behaviour 3 (1): 20-47.

Cliff, A. D., Martin, R. L., Ord, J. K. (1974): Evaluating the Friction of Distance Parameter in Gravity Models. Regional Studies 8 (3-4): 281-286.

Coleman, P. (2006): Shopping Environments. London: Routledge.

Converse, P. D. (1949): New Laws of Retail Gravitation. Journal of Marketing 14 (3): 379-384.

Connell, R. (2007): The Northern Theory of Globalization. Sociological Theory 25 (4): 368-385.

Cooper, D. (2007): Being in Public: The Threat and Promise of Stranger Contact. Law \& Social Inquiry 32 (1): 203-232.

Coshall, J. T. (1985): Urban Consumers' Cognitions of Distance. Geografiska Annaler. Series B, Human Geography 67 (2): 107-119.

Crosby, N., Hughes, C., Lizieri, C., Oughton, M. (2005): A Message from the Oracle: The Land Use Impact of a Major In-town Shopping Centre on Local Retailing. Journal of Property Research 22 (2-3): 245-265.

Cummins, S., Macintyre, S. (1999): The Location of Food Stores in Urban Areas: A Case Study in Glasgow. British Food Journal 101 (7): 545-553.

Cushman \& Wakefield (2011): European Shopping Centre Development Report September 2011. In Cushman \& Wakefield: Knowledge Center [online]. Dostupné z: <http://www.cushwake.be/cwglobal/jsp/kcReportDetail.jsp?Co untry=EMEA\&Language $=E N \&$ catld $=700003 \& p \mid d=c 37800004 p>$

Cushman \& Wakefield (2012): European Shopping Centre Development Report September 2012. In Cushman \& Wakefield: Knowledge Center [online]. Dostupné z: <http://www.cushwake.com/cwglobal/jsp/kcReportDetail.jsp? Country $=$ EMEA\&Language $=E N \&$ catld $=100004 \& p l d=c 44300013 p>$

ČTK (2012): VČR loni posílily supermarkety, preference diskontů klesly. ČeskéNoviny. cz: Ekonomika [online]. Dostupné z: http://m.ceskenoviny.cz/ekonomika/v-crloni-posilily-supermarkety-preference-diskontu-klesly/740076

Dawson, J. A., Lord, D. J. (2012): Shopping centre development. New York: Routledge.

De Vries, J. J., Nijkamp, P., Rietveld, P. (2009): Exponential or Power Distance-Decay for Commuting? An Alternative Specification. Environment and Planning $A$ 41 (2): 461-480.

Dicken, P. (2003): Global Shift. London: Sage Publications. 
Douglas, M. J. (1995): Privatisation, Growth and Sustainability of the Retail Sector in Budapest. Moravian Geographical Reports 3 (1-2): 44-52.

Drtina, T. (1989): Geografické hodnocení maloobchodní vybaveností aglomerací Čech. [Diplomová práce]. Praha: Univerzita Karlova.

Drtina, T., Krásný, T. (1989): Mezinárodnísrovnání vývojových tendencímaloobchodní sítě. Praha: Výzkumný ústav obchodu.

Dudek-Mańkowska, S., Križan, F. (2012): Shopping Centres in Warsaw and Bratislava: A Comparative Analysis. Miscelanea Geographica 14: 215-226.

England, J. R. (2000): Retail Impact Assessment: A Guide to Best Practice. London: Routledge.

Fassmann, H. (2009): Stadtgeographie I. Braunschweig: Westermann.

Fertal'ová, J. (2006): Evaluation of Attendance in Selected Hypermarkets and Shopping Stores in the Towns of Prešov and Košice. Acta Universitatis Palackianae Olomoucensis. Geographica 39: 19-29.

Findlay, A. M., Stockdale, A., Findlay, A., Short, D. (2001): Mobility as a Driver of Change in Rural Britain: An Analysis of the Links Between Migration, Commuting and Travel to Shop Patterns. International Journal of Population Geography 7 (1): 1-15.

Flowerdew, R., Martin, D. (2004): Methods in Human Geography. London: Pearson Education.

Fotheringham, A. S. (1981): Spatial Structure and Distance-Decay Parameters. Annals of the Association of American Geographers 71 (3): 425-436.

Fotheringham, A. S., O'Kelly, M. E. (1989): Spatial Interaction Models: Formulations and Applications. London: Kluwer.

Fotheringham, A. S., Brunsdon, C., Charlton, M. (2000): Quantitative Geography: Perspectives on Spatial Data Analysis. London: Sage.

Frič, P., Potůček, M. (2004): Model vývoje české společnosti a její modernizace v globálním kontextu. Sociologický časopis 40 (4): 415-431.

FSÚ (1977): Sčítání občanské vybavenosti ČSR k 31. 12. 1976. Praha: FSÚ.

Fukai, A. (2006): Fashion: A History from the 18th to the 20th Century. Berlin: Taschen Books.

Garreau, J. (1992): Edge of the city: Life on the New Frontier. Anchor: Later Printing Edition.

Giddens, A. (2002): Runway World. How Globalization is Reshaping Our Lives. London: Profile Books.

Golledge, R. G. J., Stimson, R. J. (1997): Spatial Behavior: A Geographic Perspective. New York: Guilford Press.

Goss, J. (1993): The ,Magic of the Mall': An Analysis of Form, Function and Meaning in the Contemporary Retail Built Enviroment. Annals of the Association of American Geographers 83 (1): 18-47. 
Guy, C. M. (1998a): Classifications of Retail Stores and Shopping Centres: Some Methodological Issues. GeoJournal 45 (4): 255-264.

Guy, C. M. (1998b): Controlling new retail spaces: The Impress of Planning Policies in Western Europe. Urban Studies 35 (5-6): 953-979.

Guy, C. M. (1998c): Off-centre Retailing in the UK: Prospects for the Future and the Implications for Town Centres. Built environment 24 (1): 16-30.

Hagget, P. (1965): Locational Analysis in Human Geography. London: Edward Arnold. Hagget, P. (1975): Geography: A Modern Synthesis. 2nd edition. New York: Harper and Row.

Halás, M., Klapka, P. (2010): Regionalizace Česka z hlediska modelování prostorových interakcí. Geografie 115 (2): 144-160.

Halás, M., Klapka, P. (2012): Distance Decay Function and its Application in the Territory of the Czech Republic. Acta Universitatis Palackianae Olomucensis, Facultas Rerum Naturalium, Geographica 43 (1). (v tisku)

Halás, M., Kladivo, P., Šimáček, P., Mintálová, T. (2010): Delimitation of microregions in the Czech Republic by nodal relations. Moravian Geographical Reports 18 (2): 16-22.

Hall, P. (1974): The Containment of Urban England. Geographical Journal 140 (3): 386-408.

Hall, P., Hay, D. (1980): Growth centres in the European urban system. London: Heinemann Education Books.

Hall, P. (2001): Cities in Civilization. New York: Fromm International.

Hampl, M. (2005): Geografická organizace společnosti v České republice: transformační procesy a jejich obecný kontext. Praha: Univerzita Karlova.

Hampl, M., Gardavský, V., Kühnl, K. (1987): Regionální struktura a vývoj systému osídlení ČSR. Praha: Univerzita Karlova.

Hampl, M., Kühnl, K., Ježek, J. (1978): Sociálně geografická regionalizace ČSR. Acta Demographica II. Praha: VÚSEI a ČSDS.

Haynes, K. E., Fotheringham, A. S. (1984): Gravity and Spatial Interaction Models. London: Sage.

Hägerstrand, T. (1953/1968): Innovation Diffusion as A Spatial Process. ChicagoLondon: The University of Chicago Press.

Hägerstrand, T. (1975): Time, Space and Human Conditions. In Karlqvist, A. et al. (eds.): Dynamic Allocation of Urban Space. Lexington: Saxon House: 3-14.

Heineberg, H. (2006): Stadtgeographie. Paderborn: Verlag.

Hubáčková, V., Krejčí, T. (2007): Regionální vliv Slovácka pohledem Reillyho modelu. In X. mezinárodní kolokvium o regionálních vědách. Brno: Masarykova univerzita: $220-227$.

Huff, D. L. (1964): Defining and Estimating a Trade Area. Journal of Marketing 28 (3): 34-38. 
Ilnicki, D. (2009): Przestrzenne zróżnicowanie poziomu rozwoju usług w Polsce. Teoretyczne i praktyczne uwarunkowania badań. Wrocław: Uniwersytet Wrocławski.

International Council of Shopping Centres 2012 [online]. Shopping Centres Definitions. Dostupné $\mathrm{z}<\mathrm{http}$ ://www.icsc.org/srch/lib/SCDefinitions.php>

Ira, V. (2001): Geografia času: prístup, základné koncepty a aplikácie. Geografický časopis 53 (3): 231-246.

Ira, V., Andráško, I. (2008): Quality of life in the urban environment of Bratislava: two-time spatial perspectives. Geografický časopis 60 (2): 149-178.

Isard, W. et al. (1998): Methods of Interregional and Regional Analysis. Aldershot: Ashgate.

Jackson, V., Stoel, L., Brantley, A. (2011): Mall Attributes and Shopping Value: Differences by Gender and Generation Cohort. Journal of Retailing and Consumer Services 18 (1): 1-9.

Jarboe, G. R., McDaniel, C. D. (1987): A Profile of Browsers in Regional Shopping Malls. Journal of the Academy of Marketing Sciences 15 (1): 46-53.

Jirásková, V. (2012): Spádovost za službami ve vybraném regionu. [Diplomová práce]. Brno: Masarykova univerzita.

Johnston, R. J. (1973): On Frictions of Distance and Regression Coefficients. Area 5 (3): 187-191.

Jürgens, U. (1994): Saalepark und Sachsenpark (Grossflächige Einkaufszentrum im Raum Leipzig-Halle). Geographische Rundschau 46 (9): 516-523.

Kladivo, P., Roubínek, P., Halás, M. (2010): Modelové príklady regionalizací a jejich aplikační př́nos na území Olomouckého kraje. Regionální studia 4 (2): 19-28.

Klaffke, P. (2003): Spree: A Cultural History of Shopping. Vancouver: Arsenal Pulp Press.

Knox, P. L., Pinch, S. (2000): Urban Social Geography. London: Pearson Education Limited.

Kok, H. J. (2007): Restructuring Retail Property Markets in Central Europe: Impacts on urban space. Journal of Housing and the Built Environment 22 (1): 107-126. Kolibová, B. (1999): Globalization of Retail Network by Large Corporations in the City of Brno and its Surroundings. Moravian Geographical Reports 7 (1): 44-47.

Kopale, P. K. (2010): Modeling Retail Phenomena. Journal of Retailing 86 (2): 117-124.

Kowalczyk, A. (2005): Nowe formy turystyki miejskiej. Prace i Studia Geograficzne: 155-197.

Koželouh, J. (2010): Environmentální dopady prostorové expanze velkoplošného maloobchodu $v$ České republice 2003-2009 [online]. Brno: Nesehnutí. Dostupné z: <http://www.nesehnuti.cz/publikace/vyzkum_2003-2009.pdf> Körner, M. (1998): Vstup nových (velkých) investic do území a jejich urbanistické, dopravní, sociální a jiné souvislosti. Urbanismus a územní rozvoj 1 (5): 13-14. 
Krásný, T. (1985): Nákupní spád do zařízení maloobchodní sítě. [Diplomová práce]. Praha: Univerzita Karlova.

Krásný, T. (1989): Přehled metod rozvoje maloobchodní sítě v zahraničí. Praha: Výzkumný ústav obchodu.

Krásný, T. (1990): Mezinárodní srovnání maloobchodní sítě. Praha: Výzkumný ústav obchodu.

Krejčí, T., Toušek, V. (2004): Vliv dojižd'ky za prací na situaci na trhu práce ve městě Brně. In Vystoupil, J., Klímová, V. (eds.): VII. mezinárodní kolokvium o regionálních vědách. Brno: Masarykova univerzita: 95-101.

Križan, F. (2009): Globalizácia maloobchodu: definícia základných procesov a ich analýza v slovenskej geografii maloobchodu. Geografický časopis 61 (1): 49-68.

Križan, F., Danielová, K. (2008): „Potravinové púště“ definované na základě merania dostupnosti - prípadová studia města Bratislava. Urbanismus a územní rozvoj XI (3): 26-30.

Križan, F., Tolmáči, L., Lauko, V. (2009): Identifikácia ,potravinových púšti“ na území mesta Bratislava aplikáciou mier dostupnosti. Ekonomický časopis 53 (10): 959-972.

Kroc, S. (1978): Maloobchodní sit'. Praha: Merkur.

Kroc, S., Ševera, M. (1974): Nákupní spád. Výzkumná zpráva. Praha: Výzkumný ústav obchodu.

Kulke, E. (1992): Veränderungen in der Standortstruktur des Einzelhandels: untersucht am Beispiel Niedersachsen. Münster: Lit.

Kulke, E. (1997): Einzelhandel in Europa. Geographische Rundschau 49 (9): 478-483.

Kuda, F., Smolová, I. (2007): Technické a geografické aspekty integrace neprůmyslových brownfieldů do území. Ostrava: VŠB - Technická univerzita Ostrava.

Kunc, J., Frantál, B., Tonev, P. (2010): Galerie Vaňkovka - studie nákupního chování návštěvníků. Brno: Masarykova univerzita.

Kunc, J., Frantál, B., Szczyrba, Z.,Tonev, P., Toušek, V. (2011): Shopping Centres and Shopping Behaviour: Selected Relations and Socio-Geographical Impli-cations (The Vaňkovka Gallery Brno, Czech Republic Example). Acta Universitatis Palackianae Oomucensis, Geographica: 5-17.

Kunc, J., Tonev, P., Szczyrba, Z., Greplová, Z. (2012a): Perspektivy nákupních center v České republice s důrazem na lokalizaci v urbánním prostředí. Urbanismus a územní rozvoj 15 (2): 11-17.

Kunc, J., Tonev, P., Szczyrba, Z., Frantál, B. (2012b): Commuting for Retail Shopping as a Part of the Daily Urban System (Brno, the Czech Republic). Geographia Technica 7 (1): 36-45.

Kunc, J., Tonev, P., Szczyrba, Z., Frantál, B. (2012c): Shopping Centres and Selected Aspects of Shopping Behaviour (Brno, the Czech Republic). Geographia Technica 7 (2): 39-51. 
Kunc, J., Tonev, P., Frantál, B., Szczyrba, Z. (2012d): Nákupní spád, nákupní chování a nákupní centra: príklad brněnské aglomerace (příspěvek ke studiu denních urbánních systémů). Sociologický časopis 48 (5): 879-910.

Kunc, J., Frantál, B., Tonev, P., Szczyrba, Z. (2012e): Spatial Patterns of Daily and Non-daily Commuting for Retail Shopping: Case of the Brno City, Czech Republic. Moravian Geographical Reports 20 (4): 39-54.

Kuruvilla, S. J., Josuu, N. (2010): Influence of Demographics, Shopping Orientation, Mall Shopping Attitude and Purchase Patterns on Mall Patronage in India. Joural of Retailing and Consumer Services 17 (4): 259-269.

Lambert, J. (2006): International Council of Shopping Centres. One Step Closer to a Pan-European Shopping Center Standard [on-line]. Dostupné z: <http:// www.icsc.org/srch/lib/euro_standard_only.pdf>

Laštůvková, H. (2012): Spádovost za službami ve vybraném regionu. [Diplomová práce]. Brno: Masarykova univerzita.

Lauko, V., Križan, F., Tolmáči, L. (2008): Potravinársky maloobchod na Slovensku: rurálne prostredie, čas a miesto nákupu. Acta Facultatis Rerum Naturalium Universitatis Comenianae. Geographica 51: 41-55.

Lee, M.-L., Pace, R. K. (2005): Spatial Distribution of Retail Sales. The Journal of Real Estate Finance and Economics 31 (1): 53-69.

Löffler, G. (1998): Market Areas - a Methodological Reflection on Their Boundaries. GeoJournal 45 (4): 265-272.

Lentnek, B., Lieber, S. R., Sheshkin, I. (1976): Consumer Behavior in Different Areas. Annals of the Association of American Geographers 66: 38-545.

Lloyd, R., Jennings, D. (1978): Shopping Behavior and Income: Comparisons in an Urban Environment. Economic Geography 54 (2): 157-167.

Łoboda, J. (1974): Niektóre geograficzne problemy dyfuzji innowacji. Acta Universitatis Wratislaviensis 237, Prace Instytutu Geograficznego, seria B: 49-61.

Lynch, K. (1960): The Image of the City. Cambridge: MIT Press.

Majerová, V. et al. (2003): Český venkov 2003. Situace před vstupem do EU. Praha: Česká zemědělská univerzita v Praze.

Maryáš, J. (1983): K metodám výběru středisek maloobchodu a sfér. Zprávy Ggú ČSAV 20 (3): 61-81.

Maryáš, J. (1988): Nadmístní střediska maloobchodu a služeb v ČSSR a jejich sféry vlivu. [Kandidátská disertační práce]. Brno: Geografický ústav ČSAV.

Maryáš, J. (1990): Vybrané aspekty hodnocení obslužné vybavenostiv Československu (Výzkumná zpráva). Brno: Geografický ústav ČSAV.

Maryáš, J. (1992): Vybrané aspekty hodnocení obslužných středisek v ČSFR. Zprávy Geografického ústavu ČSAV 29 (3-4): 85-126.

Maryáš, J. (2010): Atraction Zones of Services in Hinterland of Brno. In Alternativi za razvítije na svremenija turizm. Sbornik dokladi ot naučna konferencija. Varna: Ikonomičeskij Universitet: 612-616. 
Maryáš, J., Řehák, S. (1987): Regionální působnost středisek osídlení. Mapový list III.4 In Atlas obyvatelstva ČSSR. Brno: Geografický ústav ČSAV - Federální statistický úřad.

Marjanen, H. (1995): Longitudinal Study on Consumer Spatial Shopping Behaviour with Special Reference to Out-of Town. Experiences from Turku, Finland. Journal of Retailing and Consumer Services 2 (3): 163-174.

Mašíček, P. (2007): Střediska regionu Jihovýchod a jejich vybavenost v obchodu a ve službách. [Diplomová práce]. Brno: Masarykova univerzita.

Matlovič, R. (2001): Transformačné procesy a ich efekty v intraurbánnych štruktúrach postkomunistických miest. Acta Facultatis Rerum Naturalium Universitatis Matthiae Belii. Geografické štúdie 8: 73-81.

Matlovič, R., Ira, V., Szczyrba, Z., Sýkora, L. (2001): Procesy transformacyjne struktury przestrzennej miast postkomunistycznych (na przykładzie Pragi, Bratysławy, Ołomuńca oraz Preszowa). In Jażdzewska, I. (ed.): Miasto postsocjalistytczne - organizacja przestrzeni miejskiej i jej przemiany (II), XIV Konwersatorium Wiedzy o Mieście. Łódź: Uniwersytet Łódzki: 9-21

Matlovič, R., Sedláková, A. (2004): Suburbanizácia - transformačný proces priestorovej organizácie postkomunistických miest (empirický príklad Prešova). In Acta Facultatis Studiorum Humanitatis et Naturae Universitatis Prešoviensis. Folia Geographica 7. Prešov: Prešovská univerzita: 75-103.

McEachern, M. G., Warnaby, G. (2006): Food Shopping Behaviour in Scotland: The Influence of Relative Rurality. International Journal of Consumer Studies 30 (2): 198-201.

Millan, E. S., Howard, E. (2007): Shopping for pleasure? Shopping Experiences of Hungarian Consumers. International Journal of Retail \& Distribution Management 35 (6): 474-487.

Miller, E. J., O'Kelly, M. E. (1983): Estimating Shopping Destination Choice Models from Travel Diary Data. The Professional Geographer 35: 440-449.

Mitríková, J. (2008): Geografické aspekty transformácie maloobchodu a nákupného správania sa na Slovensku (prípadové štúdie z miest Prešov a Košice). Prešov: Prešovská univerzita.

Moderní obchod (5/2010).

Moody, S. (1996): Nakupovanie a architektúra. Projekt Revue 38 (4): 56-57.

Mowen, J. C. (1987): Consumer Behavior. New York: Macmillan.

Mulíček, O. (2004): Město Brno v období transformace. [Disertační práce]. Brno: Masarykova univerzita.

Mulíček, O. (2007): Prostorové aspekty současného vývoje maloobchodní sítě. Urbanismus a územní rozvoj X (6): 14-20.

Mulíček, O., Osman, R. (2009): Průzkum maloobchodní sítě na území města Brna 2009. Brno: Masarykova univerzita. 
Mulíček, O., Osman, R., Seidenglanz, D. (2010): Časoprostorové rytmy města industriální a postindustriální Brno. In Barbora, V., Ferenčuhová, S., Galčanová, L. (eds.): Československé město včera a dnes: Každodennost - reprezentace - výzkum. Červený Kostelec, Brno: Pavel Mervart, Masarykova univerzita: 195-220.

Musil, J. (2001): Vývoj a plánování měst ve střední Evropě v období komunistických režimů. Sociologický časopis 37 (3): 275-296.

Nagy, E. (1999): Fall and Revival of City Centre Retailing: Plannig an Urban Function in Leicester, Britain. Discussion papers. Pécs: Centre for Regional Studies of Hungarian Academy of Science.

Namyślak, B. (2006): Rozwoj wielkopowierzchniowych obiektow handlowych we Wroclawiu. In Jazdzewska, I. (ed.): XIX Konwersatorium Wiedzy o Miescie: Nowe przestrzenie w miastach, ich organizacja i funkcje. Łódź: Wydawnictwo Uniwersytetu Łodźkiego: 265-276.

Ordeltová, M., Szczyrba, Z. (2006): Současná situace v maloobchodní síti českých měst - geografická sonda Zlín. Urbanismus a územní rozvoj IX (3): 13-16.

Ouředníček, M., Tmelová, J., Macešková, M., Novák, J., Puldová, P., Romportl, D., Chuman, T., Potǔčková, M., Kolář, J., Kupková, L. (2008): Suburbanizace.cz. Praha: Univerzita Karlova v Praze.

Pacione, M. (2009): Urban geography. A Global Perspective. London: Routledge.

Poole, R., Clarke, G. P., Clarke, D. B. (2002): Growth, concentration and regulation in European food retailing. European urban and regional studies 9 (2): 167-186. Pooler, J. (1994): An Extended Family of Spatial Interaction Models. Progress in Human Geography 18 (1): 17-39.

Pospěch, P. (2010): Význam a normalita ve veřejném prostoru a v nákupním centru. In Vacková, B., Ferenčuhová, S., Galčanová, L. (eds.): Československé město včera a dnes: Každodennost - reprezentace - výzkum. Červený Kostelec, Brno: Pavel Mervart, Masarykova univerzita: 113-136.

Potter, R. B. (1979): Perception of Urban Retailing Facilities: An Analysis of Consumer Information Fields. Geografiska Annaler, Series B, Human Geography 61 (1): 19-27.

Potůčková, E. (2012): Spádovost za službami ve vybraných regionech v českorakouském pohraničí. [Diplomová práce]. Brno: Masarykova univerzita.

Pražská, L, Jindra, J. (1997): Retail management. Praha: Management Press.

Pred, A. (1977): The Choreography of Existence: Comments on Hägerstrand's Time-geography and its Usefulness. Economic Geography 53 (2): 207-221.

Ptáček, P. (2002): Surbanizace v USA a Německu: zdroj inspirace a poučení. In Sýkora, L. (ed.): Suburbanizace a její sociální a ekologické důsledky. Praha: Ústav pro ekopolitiku, o. p. s.: 55-80.

Ravenstein, E. G. (1885): The Laws of Migration. Journal of the Statistical Society of London 48 (2): 167-235. 
Reilly, W. J. (1929): Methods for the Study of Retail Relationships. Austin: University of Texas (University of Texas Bulletin no. 2944).

Reilly, W. J. (1931): The Laws of Retail Gravitation. New York: Knickerbocker Press. Retail Info Plus 1-2 (2013a): Jak ovlivní obchod internetová generace? [online]. Dostupné z: http://www.retailinfo.cz/plus/2013/1/?pn=18

Retail Info Plus 1-2 (2013b): Př́jemný nákup pro zákazníka, zvýšení efektivity pro obchodníka. [online]. Dostupné z: http://www.retailinfo.cz/plus/2013/1/ ?pn=18

Reynolds, J. (1992): Generic Models of European Shopping Centre Development. European Journal of Marketing 26 (8-9): 48-60.

Ritzer, G. (1999): Mcdonaldizace společnosti. Praha: Academia.

Rogers, E. M. (1962/2003): Diffusion of Innovations. Fifth edition. New York: Free Press.

Ryšavý, Z. (1970): Územní rozbor obchodní sítě a sítě služeb v Ostravě. Výstavba a architektura 6: 7-11.

Ryšavý, Z. (1980): Analýza občanské vybavenosti města Hradce Králové. Hradec Králové: Dům techniky ČSVTS.

Rushton, G. (1969): Analysis of Behavior by Revealed Space Preference. Annals of Association of American Geogpraphers 59 (2): 391-400.

Řehák, S. (2004): Metodický dodatek. In:Jeřábek, M., Dokoupil, J., Havličcek, T. (eds.): České pohraničí, bariéra, nebo prostor zprostředkování? Praha: Academia: 269-273.

Řehák, S., Halás, M., Klapka, P. (2009): Několik poznámek k možnostem aplikace Reillyho modelu. Geographia Moravica 1: 47-58.

Saarinen, T. F. (1976): Environmental Planning, Perception and Behavior. Boston: Houghton Mifflin Company.

Scott, P. (1973): Geography and Retailing. London: Hutchinson.

Scott, D. M., He, S. Y. (2012): Modeling Constrained Destination Choice for Shopping: A GIS-Based, Time-Geographic Approach. Journal of Transport Geography 23: 60-71.

Senior, M. L. (1979): From Gravity Modelling to Entropy Maximising: a Pedagogic Guide. Progress in Human Geography 3 (2): 174-210.

Severin, V., Louviere, J. J., Finn, A. (2001): The Stability of Retail Choices Over Time and Across Countries. Journal of Retailing 77 (2): 185-202.

Shaw, H. J. (2006): Food Deserts: Towards the Development of a Classification. Geografiska Annaler, Series B, Human Geography 88 (2): 231-247.

Shepherd, I. D. H., Thomas, C. L. (1980): Urban Consumer Behavior. In Dawson, J. A. (ed.): Retail Geography. New York: Wiley: 18-94.

Sheppard, E. S. (1978): Theoretical Underpinning of the Gravity Hypothesis. Geographical Analysis 10 (4): 386-402.

Shields, R. (1992): Lifestyle Shopping: The Subject Consumption. London: Routledge. 
Schiffmann, L. G., Kanuk, L. L. (2004): Nákupní chování. Brno: Computer Press. Siwek, T. (1979): Příklad využití teorie difuze inovace v geografii na území Slovenska. Geografický časopis 31 (3): 297-303.

Smailes, A. E. (1967): Hierarchia miast w Anglii i Walii. Przeglad z zagranicznej literatury geograficznej 2. Geography. The Quarterly Journal of the Geographical Association 144 (29): 41-51.

Smith, A., Sparks, L. (2000): The Role and Function of the Independent Small Shop: The Situation in Scotland. The Internacional Review of Retail, Distribution and Consumer Research 10 (2): 205-226.

Snickars, F., Weibull, J. W. (1977): A Minimum Information Principle: Theory and Practice. Regional Science and Urban Economics 7 (1-2): 137-168.

Spilková, J. (2003): Nový fenomén: nákupní centrum a utváření nákupního chování spotřebitelů v transformačním období. Geografie 108 (4): 277-288.

Spilková, J., Hochel', M. (2009): Toward the Economy of Pedestrian Movement in Czech and Slovak Shopping Malls. Environment and Behavior 41 (3): 443-455. Spilková, J. (2010): Retail Development and Impact Assessment in Czech Republic:

Which Tools to Use? European Planning Studies 18 (9): 1469-1484.

Spilková, J. (2012a): Geografie maloobchodu a spotřeby. Praha: Karolinum.

Spilková, J. (2012b): The Birth of the Czech Mall Enthusiast: The Transition of Shopping Habbits from Utilitarian to Leisure Shopping. Geografie 117 (1): 21-32.

Spilková, J., Perlín, R. (2010): Czech Physical Planning at the Crossroads: Towards the Regulation of Large-scale Retail Developments? Environment and Planning C: Government and Policy 28 (2): 290-303.

Spilková, J., Šefrna, L. (2010): Uncoordinated New Retail Development and its on Land Use and Soils: A Pilot Study on the Urban Fringe of Prague, Czech Republic. Lanscape and Urban Planning 94 (2): 141-148.

Stewart, J. Q. (1948): Demographic Gravitation: Evidence and Applications. Sociometry 11 (1/2): 31-58.

Starzyczná, H., Steiner, J. (2000): Maloobchod v českých zemích v proměnách let 1918-2000. Karviná: Slezská univerzita v Opavě.

Starzyczná, H. (2010): Vybrané aspekty internacionalizace vnitřního obchodu v teoretických př́stupech a v empirickém zkoumání v České republice v období transformace. E + M Ekonomie a management 1/2010: 115-130.

Steinführer, A. (2006): The Urban Transition of Inner City Areas Reconsidered (a German-Czech Comparison). Moravian Geographical Reports 14 (1): 3-16. Sýkora, L. (1988): Hierarchie středisek maloobchodní sítě ČSR. [Diplomová práce]. Praha: Univerzita Karlova.

Sýkora, L. (2001): Proměny prostorové struktury Prahy v kontextu postkomunistické transformace. In Hampl, M. (ed.): Regionálnívývoj: specifika české transformace, evropská integrace a obecná teorie. Praha: Univerzita Karlova: 127-166. 
Sýkora, L. (2003): Suburbanizace a její společenské důsledky. Sociologický časopis 39 (2): 217-233.

Sýkora, L., Mulíček, O. (2009): The Micro-regional Nature of Functional Urban Areas (FUAs): Lessons From the Analysis of the Czech Urban and Regional System. Urban Research \& Practice 2 (3): 287-307.

Szczyrba, Z. (2002): Shopping Gravity of Large-scale Stores - Example of Terno Olomouc Hypermarket (Contribution to the Study of the Problematic). Acta Universitatis Palackianae Olomucensis, Geographica 37: 91-96.

Szczyrba, Z. (2004): Územní specifika vývoje maloobchodní sítě v Česku po roce 1989. Geographia-Geologia 6: 131-134.

Szczyrba, Z. (2005): Maloobchod v ČR po roce 1989 - vývoj a trendy se zaměřením na geografickou organizaci. Olomouc: Univerzita Palackého.

Szczyrba, Z. (2006): Geografie obchodu se zaměřením na současné trendy v maloobchodě. Olomouc: Univerzita Palackého.

Szczyrba, Z. (2010): Development of the Geographical Structure of Retail Business in Czech Republic - Part of the Study of Changes in the Urban Environment. Geographica 41 (2): 5-20.

Szczyrba, Z. et al. (2005): Procesy transformacyjne w handlu detalicznym w ukladzie regionalnym Republiky Czeskiej (modelowa sytuacja w regione Morawy Środkowej). In Kosiedowski, W. (ed.): Regiony Europy Środkowej i Wschodniej wobec globalizacji i integracji miedzynarodowej. Wloclawek: Uniwersytet Mikolaja Kopernika w Toruniu - Wloclawskie Towarzystwo Naukowe: 409-412.

Szczyrba, Z., Ira, V., Matlovič, R., Sýkora, L. (2001): Przekszałcenia przestrzeni wymiany handlowej miasta postsocjalistycznego na tle koncentracji w handlu detalicznym w Republice Czeskiej i Słowacji (przykład Pragi, Bratysławy, Ołomuńca i Preszowa). In Jażdzewska, I. (ed.): Miasto postsocjalistytczne organizacja przestrzeni miejskiej i jej przemiany (II), XIV Konwersatorium Wiedzy o Mieście. Łódź: Uniwersytet Łódzki: 243-251.

Szczyrba, Z., Klapka, P., Kunc, J., Tonev, P. (2007): Difúzní procesy v prostředí českého maloobchodu. Regionální studia 1 (1): 8-12.

Szczyrba, Z., Smolová, I., Fňukal, M. (2006): Significant Features of Transformation of the Services Sector in an Area - a Case Study for the Micro-Region of Olomoucko (Contribution to Research on the Issue). Acta Universitatis Palackianae Olomucensis, Geographica 39: 83-93.

Szczyrba, Z., Toušek, V. (2006): Nákupní centra v České republice - nová fáze transformace českého maloobchodu. In Acta Facultatis Studiorum Humanitatis Et Naturae Universitatis Prešoviensis, Folia Geographica 10: (45). Prešov: Prešovská univerzita: 492-499.

Šimůnek, J. et al. (1988): Optimalizace rozvoje maloobchodní sítě ve vybraných městech ČSR. Praha: Výzkumný ústav obchodu. 
Šveda, M., Križan, F. (2010): Prejavy komerčnej suburbanizácie vo vybraných odvetviach hospodárstva v zázemí Bratislavy. Ekonomický časopis 60 (5): 460-481. Taylor, P. J. (1971): Distance Transformation and Distance Decay Function. Geographical Analysis 3 (3): 221-238.

Teller, Ch. (2008): Shopping Streets versus Shopping Malls - Determination of Agglomeration Format Attractiveness from the Consumers' Point of View. International Review of Retail, Distribution and Consumer Research 18 (4): 381-403.

Timmermans, H., Van Der Heijden, R., Westerveld, H. (1982): Perception of Urban Retailing Environments: An Empirical Analysis of Consumer Information and Usage Fields. Geoforum 13 (1): 27-37.

Timothy, D. J. (2005): Shopping Tourism, Retailing, and Leisure. New York: Channel View Publications.

Tobler, W. (1983): An Alternative Formulation for Spatial-Interaction Modelling. Environment and Planning A 15 (5): 693-703.

Tonev, P. (1998): Změny maloobchodní sítě v ČR v první polovině devadesátých let. [Diplomová práce]. Brno: Masarykova univerzita.

Trembošová, M. (2009): Intraurbánne spádové oblasti maloobchodnej vybavenosti v meste Nitra v roku 2008. Geografické štúdie 13: 94-111.

Trembošová, M. (2010): Vybrané aspekty transformácie maloobchodu v meste Nitra v rokoch 1992-2008. Geografický časopis 62 (1): 49-73.

Trivedi, M. (2011): Regional and Categorical Patterns in Consumer Behavior: Revealing Trends. Journal of Retailing 87 (1): 18-30.

Underhill, P. (2004): Call of the Mall. The Geography of Shopping by the Author and Why We Buy. New York: Simon \& Schuster.

Vacek, P. (2010): Spádovost za službami ve vybraném regionu. [Diplomová práce]. Brno: Masarykova univerzita.

Van Leeuwen, E. S., Rietveld, P. (2011): Spatial Consumer Behaviour in Small and Medium-sized Towns. Regional Studies 45 (8): 1107-1119.

Vaishar, A. (1983): Občanská vybavenost. In Geoekologie brněnské aglomerace. Studia geographica 83: 234-254.

Vepřek, J. (2012): Regionotvorné procesy a jejich hierarchie na př́kladě města Brna. [Diplomová práce]. Brno: Masarykova univerzita.

Viturka, M., Maryáš, J., Toušek, V., Vystoupil, J. (1998): Investiční atraktivita vybraných měst České republiky. Brno: Masarykova univerzita.

Viturka, M., Toušek, V., Tonev, P. (2003): Posouzení stavu, využitelnosti a možného dalšího rozvoje průmyslových zón kraje Vysočina. In Sborník referátů z VI. mezinárodního kolokvia o regionálních vědách. Brno: Masarykova univerzita: 215-228.

Vogt, M. (1988): Verbrauchmärkte, SB-Warenhäuser und Einkaufszentrenals neue Elemente im Standortgefüge des Einzelhandels in Grossraum Stuttgart. Stuttgarter Geographische Studien 109: 15-33. 
Voyce, M. (2006): Shopping Malls in Australia. The End of Public Space and the Rise of Consumerist Citizenship? Journal of Sociology 42 (3): 269-286.

Vysekalová, J. (2003): Jak to bylo s Českým snem? Marketing \& Komunikace 8 (4): 8-10.

Vysekalová, J. (2004): Psychologie spotřebitele. Jak zákazníci nakupují. Praha: Grada. Wagner, T., Rudolph, T. (2010): Towards a Hierarchical Theory of Shopping Motivation. Journal of Retailing and Consumer Services 17 (5): 415-429.

Walmsley, D. J., Lewis, G. J. (1984): Human Geography: Behavioural Approaches. London: Longman.

Wilk, W. (2005): Miesjce miast w sieciach handlowych - przykład Polski. Prace a Studia Geograficzne 35: 129-153.

Wilson, A. (2010): Entropy in Urban and Regional Modelling: Retrospect and Prospect. Geographical Analysis 42 (4): 364-394.

Wilson, A. G. (1967): Statistical Theory of Spatial Distribution Models. Transportation Research 1: 253-269.

Wilson, A. G. (1974): Urban and Regional Models in Geography and Planning. London: Wiley.

Wokoun, R. (1981): Vybrané problémy geografie obchodu města Brna a jeho spádového území. In Sborník referátů 15. sjezdu ČSGS. Brno: ČSAV: 358-362.

Wokoun, R. (1983): Regionálně geografická analýza spádu do obchodního centra města Brna (na príkladu obchodního domu PRIOR). [Kandidátská disertační práce]. Brno: UJEP.

Wrigley, N. (2002): Food deserts in British cities: Policy contex and research priorities. Urban Studies 39 (11): 2029-2040.

Wrigley, N. (2003): The Globalization of Retail Capital: Themes for Economic Geography. In Clark, G. L., Feldman, M. P., Gertler, M. S. (eds.): The Oxford Handbook of Economic Geography. New York: Oxford University Press: 292-313.

Zákon č. 183/2006 Sb., o územním plánování a stavebním řádu.

Zenk, S. N., Schulz, A. J., Izrael, B. A., James, S. A., Bao, S., Wilson, M. L. (2005): Neighborhood Racial Composition, Neighborhood Poverty, and the Spatial Accessibilty of Supermarkets in Metropolitan Detroit. American Journal of Public Health (95) 4: 660-667.

Žák, I. (2012): Spádovost za službami ve vybraném regionu. [Diplomová práce]. Brno: Masarykova univerzita.

http://blsciblogs.baruch.cuny.edu/his1005fall2010/2010/11/16/one-stop-shop/ http://pariz-pro-pokrocile.blog.cz/1202/obchodni-dum-le-bon-marche 


\section{Věcný rejstríik}

\begin{tabular}{|c|c|}
\hline behaviorální geografie & 17 \\
\hline bezkontaktní platební karty & 19,175 \\
\hline cestovní ruch & $7,15,20,98$ \\
\hline decentralizace & $17,51,55,116$ \\
\hline denní dojížd’ky & $15,90,102,104,112,113,141,173$ \\
\hline denní nákupy & $103,109,117,126-128,132-134,137-139$ \\
\hline denní urbánní systém & $10,15,29,116,125,139,141,154,157,159,174$ \\
\hline dojiźďka za maloobchodem & $\begin{array}{l}10,16,22,23,29,101,102,112-114,117,125, \\
137,153\end{array}$ \\
\hline edge-of-centre & 20,69 \\
\hline environmental Impact Assessment & 49 \\
\hline expresní prodejny & 42 \\
\hline factory outlet centra & $17,66,67$ \\
\hline franchising & 31 \\
\hline Geografický ústav ČSAV Brno & 23 \\
\hline geografie času & 16 \\
\hline globalizace & $9,14,16$ \\
\hline gravitační modely & $25-27,30,160-162,172$ \\
\hline komerční suburbanizace & $20,31,55$ \\
\hline komplexní obslužné regiony & $141,143,154-157$ \\
\hline konzumní způsob života & 20,57 \\
\hline lokalizace nákupních center & $20,62,78,79,128,129$ \\
\hline Maslowova hierarchie potřeb & 16 \\
\hline mega mall & 58 \\
\hline mobilní nakupování & 19 \\
\hline modelování prostorových interakcí & $7,10,25,26,30,159,160,172$ \\
\hline modely mezilehlých příležitostí & 27 \\
\hline motivační faktory & $16,19,102,110,115,126$ \\
\hline multichannel retailing & 13 \\
\hline nahodilé nákupy & 18 \\
\hline nákupní galerie & 21,65 \\
\hline nákupní proces & $13,122,123,175$ \\
\hline nákupní spád & $\begin{array}{l}10,20,21,24,25,29,51,89,98,101,112, \\
125-127,137,138\end{array}$ \\
\hline ákupy pro domácnost & 17 \\
\hline ákupy pro zábavu & 20,57 \\
\hline
\end{tabular}




\begin{tabular}{|c|c|}
\hline nákupy z „nutnosti“ & 20, 57 \\
\hline nedenní dojížd'ky & $11,16,29,30,101,102,112,114,125$ \\
\hline nákupy) & $126,127,133,135,138$ \\
\hline obslužný standard & 33 \\
\hline osobní nákupy & 17 \\
\hline out-of-centre & 20,69 \\
\hline out-of-town & $16,20,69$ \\
\hline parciální obslužné regiony & 145 \\
\hline plošný standard & $34,36,37,50-52$ \\
\hline potravinové pouště & 32,116 \\
\hline regionalizace & $23,141,144,154$ \\
\hline regionotvorné procesy & 117,147 \\
\hline reillyho model maloobchodní & \\
\hline gravitace & $25-27,142$ \\
\hline rekreační nakupování & $15,16,20$ \\
\hline remodeling & 85 \\
\hline retail Impact Assessment & 49 \\
\hline retail-led urban regeneration & 82 \\
\hline samoobslužné pokladny & $13,19,175$ \\
\hline sčítání maloobchodu & 32 \\
\hline sítová struktura českého & \\
\hline $\begin{array}{l}\text { maloobchodu } \\
\text { specializovaný model nákupního }\end{array}$ & 39,42 \\
\hline $\begin{array}{l}\text { specializovany model nakupnino } \\
\text { centra }\end{array}$ & 66 \\
\hline spotřebitelské chování & $11,12,15,17,18,21,22$ \\
\hline střediska základní obsluhy & 23 \\
\hline šetření Hypermarket 2011 & 40,41 \\
\hline tradiční model nákupního centra & 66 \\
\hline transformace maloobchodu & $12,24,36,38,51,53-55$ \\
\hline týdenní (víkendové) nákupy & $126,127,128,134$ \\
\hline účelové nákupy & 18 \\
\hline vícerozměrné regresní analýzy & 30 \\
\hline víceúčelové nákupy & 18 \\
\hline virtuální regály & 14,175 \\
\hline Výzkumný ústav obchodu Praha & 23 \\
\hline základní obslužné regiony & $23,34,120$ \\
\hline zelený přístup & 14 \\
\hline
\end{tabular}





\section{Vědecká redakce MU}

prof. PhDr. Ladislav Rabušic, CSc.

prof. RNDr. Zuzana Došlá, DSc.

Ing. Radmila Droběnová, Ph.D.

Mgr. Michaela Hanousková

doc. PhDr. Jana Chamonikolasová, Ph.D.

doc. JUDr. Josef Kotásek, Ph.D.

Mgr. et Mgr. Oldřich Krpec, Ph.D.

prof. PhDr. Petr Macek, CSc.

PhDr. Alena Mizerová

doc. Ing. Petr Pirožek, Ph.D.

doc. RNDr. Lubomír Popelínský, Ph.D.

Mgr. David Povolný

Mgr. Kateřina Sedláčková, Ph.D.

prof. MUDr. Anna Vašků, CSc.

prof. PhDr. Marie Vítková, CSc.

Mgr. Iva Zlatušková

doc. Mgr. Martin Zvonař, Ph.D.

Josef KUNC a kolektiv

\section{ČASOPROSTOROVÉ MODELY NÁKUPNÍHO CHOVÁNÍ ČESKÉ POPULACE}

Návrh obálky: Jarmila Marvanová

Ediční rada: L. Blažek, V. Hyánek, E. Hýblová, M. Kvizda, R. Lukášová, J. Maryáš, J. Nekuda, D. Němec

Jazyková revize: Mgr. Eva Strnadová

Vydala Masarykova univerzita roku 2013

1. elektron. vydání

Sazba: Reprocentrum, a. s., Bezručova 29, 67801 Blansko

ISBN 978-80-210-6465-2

ISBN 978-80-210-6020-3 (brož. vaz.)

DOI 10.5817/CZ.MUNI.M210-6020-2013 
Český maloobchod prochází obdobím největších změn v celé své historii. Na kapacitní i kvalitativní nedostatečnost odvětví z konce 80 . let minulého století navázala $v$ první polovině let devadesátých etapa atomizace, podpořená malou privatizací, kdy se počet maloobchodních jednotek za deset let zvýšil dvojnásobně na téměř 100 tisíc. Od 2. poloviny 90 . let začaly ve větší míře pronikat na tuzemský trh zahraniční řetězce a český maloobchod se velmi rychle internacionalizoval. Vstup zahraničního kapitálu byl dominantní, domácí subjekty nebyly reálně konkurenceschopné. Pokračovala transformace maloobchodu, jehož sítová struktura se opírala o stále větší počet velkoplošných maloobchodních jednotek (super- a hypermarkety, diskonty), objevila se první nákupní centra.

Předložená publikace nabízí čtenářum hlavní výsledky projektu „Časoprostorová organizace denních urbánních systémů: analýza a hodnocení vybraných procesư". Denní rytmus obyvatel zde není primárně vázán na pohyb za prací, ale je modifikován dojižd'kou za službami a specificky za maloobchodem, resp. je dotvářen novými formami nákupního chování. V první části textu je představen teoretický základ nákupního chování jako sociálněprostorového fenoménu, dále navazuje transformace českého maloobchodu a fenomén nákupních center. Druhá část práce je založena na výsledcích rozsáhlých šetření v modelových aglomeracích Brna a Olomouce. 
Český maloobchod prochází obdobím největších změn v celé své historii. Na kapacitní i kvalitativní nedostatečnost odvětví z konce 80 . let minulého století navázala $v$ první polovině let devadesátých etapa atomizace, podpořená malou privatizací, kdy se počet maloobchodních jednotek za deset let zvýši dvojnásobně na téměř 100 tisíc. Od 2. poloviny 90 . let začaly ve větší míře pronikat na tuzemský trh zahraniční řetězce a český maloobchod se velmi rychle internacionalizoval. Vstup zahraničního kapitálu byl dominantní, domácí subjekty nebyly reálně konkurenceschopné. Pokračovala transformace maloobchodu, jehož sítová struktura se opírala o stále větší počet velkoplošných maloobchodních jednotek (super- a hypermarkety, diskonty), objevila se první nákupní centra.

Předložená publikace nabízí čtenářům hlavní výsledky projektu „Časoprostorová organizace denních urbánních systémů: analýza a hodnocení vybraných procesů“. Denní rytmus obyvatel zde není primárně vázán na pohyb za prací, ale je modifikován dojížd'kou za službami a specificky za maloobchodem, resp. je dotvářen novými formami nákupního chování. V první části textu je představen teoretický základ nákupního chování jako sociálněprostorového fenoménu, dále navazuje transformace českého maloobchodu a fenomén nákupních center. Druhá část práce je založena na výsledcích rozsáhlých šetření v modelových aglomeracích Brna a Olomouce.

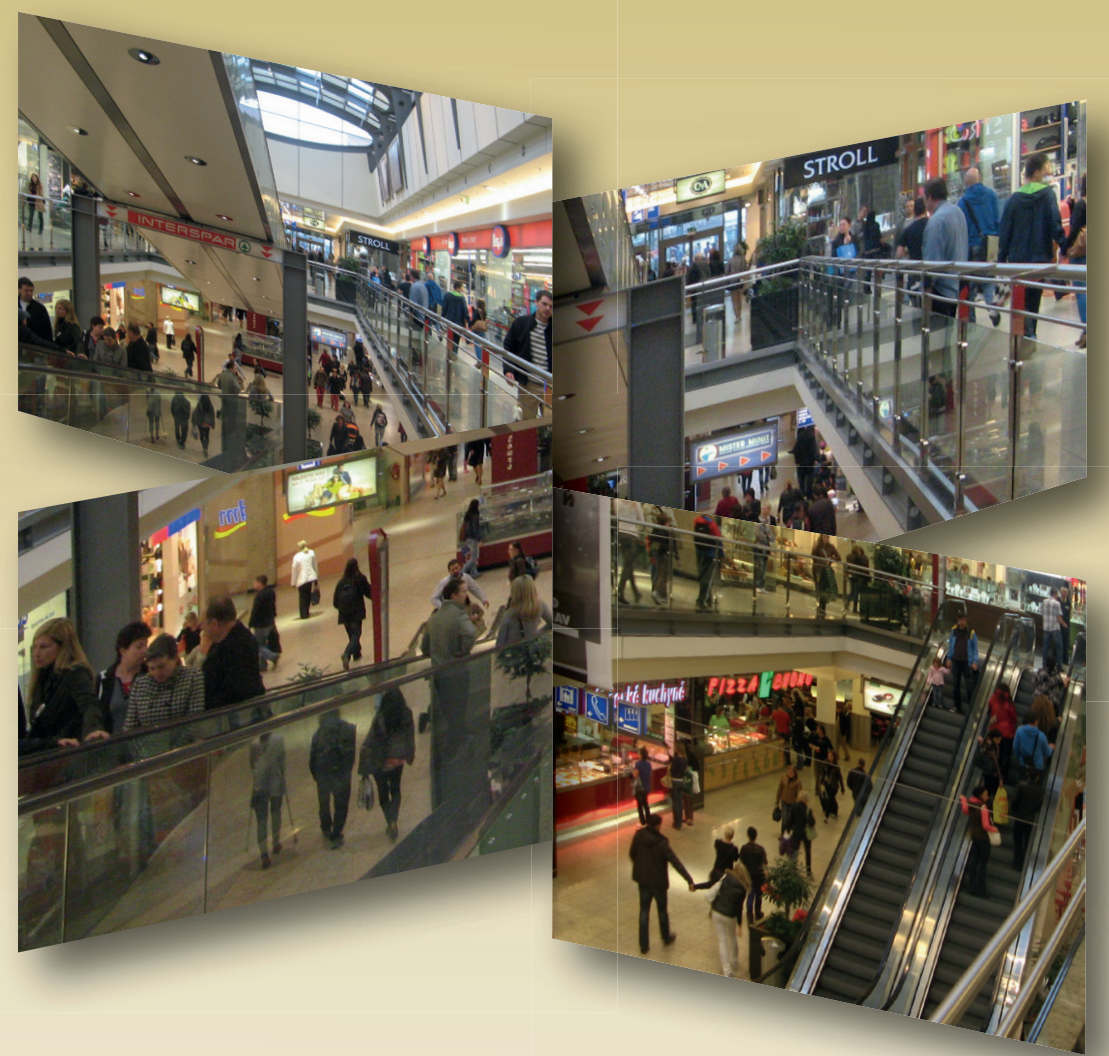

\section{ČASOPROSTOROVÉ MODELY NÁKUPNÍHO CHOVÁNÍ ČESKÉ POPULACE}

Josef KUNC

a kolektiv

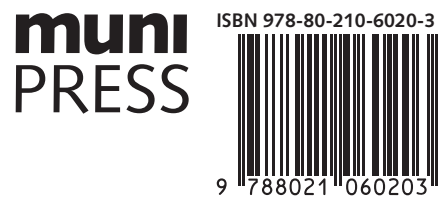

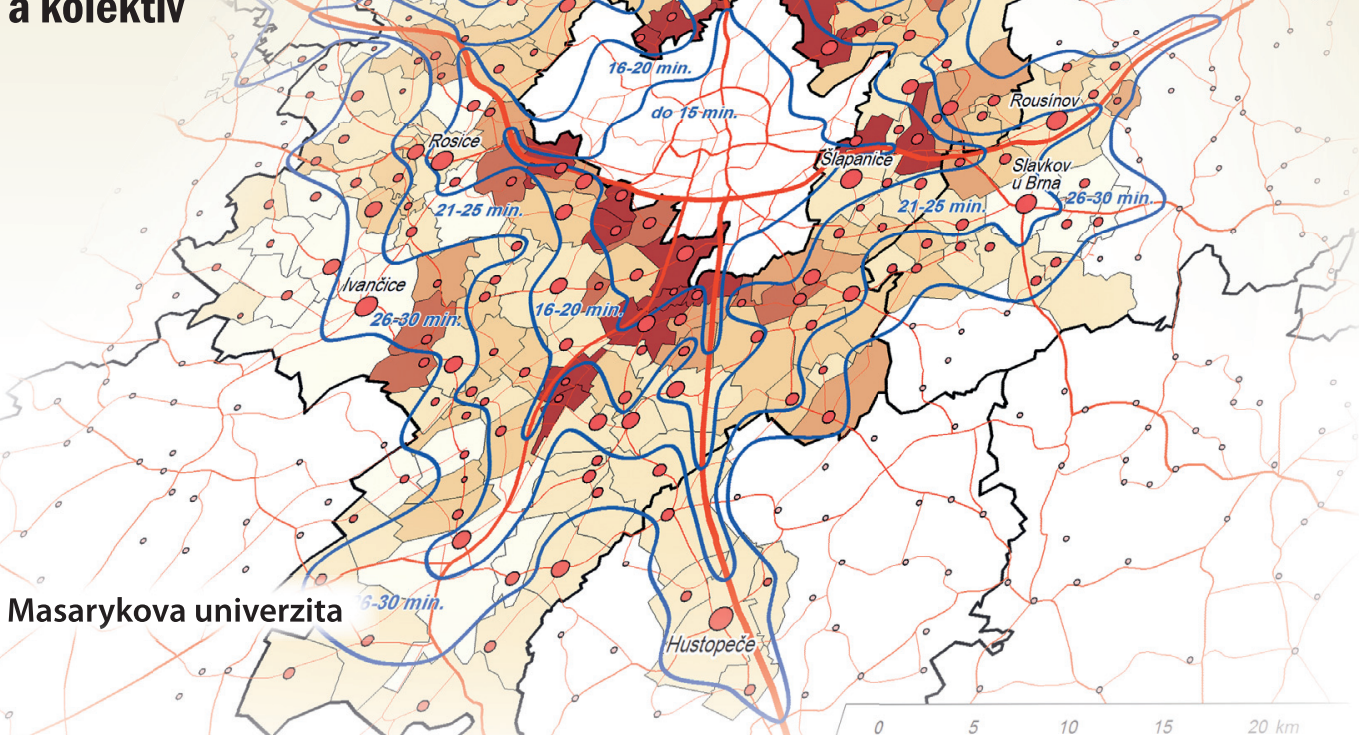

